\title{
A ODONTOLOGIA EM SAÚDE DO TRABALHADOR COMO UMA NOVA ESPECIALIDADE PROFISSIONAL: DEFINIÇÃO DO CAMPO DE ATUAÇÃO E FUNÇÕES DO CIRURGIÃO-DENTISTA NA EQUIPE DE SAÚDE DO TRABALHADOR
}

EDWARD TOSHIYUKI MIDORIKAWA

Dissertação apresentada à Faculdade de Odontologia da Universidade de São Paulo, para obtenção do Título de Mestre pelo Curso de Pós-Graduação em Odontologia.

Área de concentração: Deontologia e Odontologia Legal. 


\section{A ODONTOLOGIA EM SAÚDE DO TRABALHADOR COMO UMA NOVA ESPECIALIDADE PROFISSIONAL: DEFINIÇÃO DO CAMPO DE ATUAÇÃO E FUNÇÕES DO CIRURGIÃO-DENTISTA NA EQUIPE DE SAÚDE DO TRABALHADOR}

\footnotetext{
EDWARD TOSHIYUKI MIDORIKAWA

Dissertação apresentada à Faculdade de Odontologia da Universidade de São Paulo, para obtenção do Título de Mestre pelo Curso de Pós-Graduação em Odontologia.

Área de concentração: Deontologia e Odontologia Legal.

Orientador:

Prof. Dr. Marco Segre
}

\section{São Paulo}

2000 
Data da Defesa:

1

BANCA EXAMINADORA

Prof. Dr.

Julgamento:

Assinatura:

Prof. Dr.

Julgamento:

Assinatura:

Prof. Dr.

Julgamento:

Assinatura: 
Catalogação-na-Publicação

Serviço de Documentação Odontológica

Faculdade de Odontologia da Universidade de São Paulo

Midorikawa, Edward Toshiyuki

A odontologia em saúde do trabalhador como uma nova especialidade profissional: definição do campo de atuação e funções do cirurgião-dentista na equipe de saúde do trabalhador / Edward Toshiyuki Midorikawa ; orientador Marco Segre. -- São Paulo, 2000.

$337 f$.

Dissertação (Mestrado - Curso de Pós-Graduação em Odontologia. Área de concentração em Deontologia e Odontologia Legal) -- Faculdade de Odontologia da Universidade de São Paulo.

1. Saúde ocupacional - Odontologia 2. Saúde bucal - Trabalhador 


\section{Dedico esta Dissertação}

A Nosso Senhor Jesus Cristo e a Maria, nossa mãe, pela vida $e$ por mais esta conquista;

Aos meus pais, Toshio e Luzia, pela educação, carinho $e$ compreensão.

Ao Prof.Dr.Edson, meu irmão, pelo exemplo, apoio, conversas e sugestões.

À Silvia, minha amiga $e$ companheira, pelo apoio, carinho e compreensão nos momentos de privação de lazer. 


\section{AGRADECIMENTOS}

Ao Prof.Dr. Marco Segre, pela acolhida no Departamento de Medicina Legal, Ética Médica e Medicina Social e do Trabalho da Faculdade de Medicina da Universidade de São Paulo, que me possibilitou os primeiros contatos com a Saúde do Trabalhador - base da Odontologia em Saúde do Trabalhador -, e pela orientação nesta dissertação.

À Profa.Dra. Maria Ercilia de Araujo, pela amizade, confiança e coorientação nesta dissertação.

Ao Prof.Dr. Moacyr da Silva, pela apresentação deste tema, sugerindo trabalhos para leitura, pela oportunidade de cursar o Mestrado e pelo apoio neste caminho.

Ao Prof.Dr. Iris Noboru Nagano, pela amizade, apoio e conselhos pessoais e acadêmicos.

À Marieta Trancoso de Castro, pelo apoio e suporte em todos os momentos necessários no transcorrer do Curso, e pela revisão deste trabalho.

À bibliotecária Luzia M. Zoppei Murgia e Moraes e a todos os funcionários do Serviço de Documentação Odontológica da Faculdade de Odontologia da Universidade de São Paulo, pelo apoio dado a este pós-graduando.

Aos demais docentes e funcionários do Departamento de Odontologia Social da Faculdade de Odontologia da Universidade de São Paulo, e aos colegas e amigos do Curso de Pós-Graduação em Deontologia e Odontologia Legal, pela amizade, paciência e apoio em todos os momentos desta jornada.

Às empresas que me ajudaram na coleta de informações respondendo ao questionário, e às pessoas que, de diferentes maneiras, ajudaram a construir e consolidar os conhecimentos sobre Odontologia em Saúde do Trabalhador, mostrando que o caminho a percorrer ainda é longo, mas que a direção é certa. 



\section{SUMÁRIO}

\section{RESUMO}

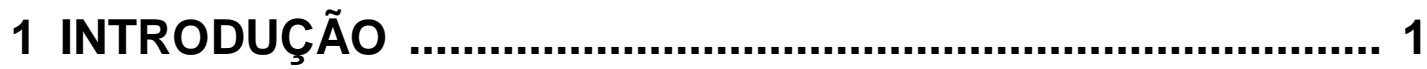

2 REVISÃO DA LITERATURA ............................................... 5

2.1 BREVE HISTÓRICO DO HOMEM NO TRABALHO E A EVOLUÇÃO DO SISTEMA DE PRODUÇÃO ATÉ O SÉCULO XX.... 5

2.2 DOS PRIMEIROS ESTUDOS DA SAÚDE NO TRABALHO ATÉ A SAÚDE DO TRABALHADOR

2.3 DA ODONTOLOGIA NO AMBIENTE DE TRABALHO ATÉ A ODONTOLOGIA SOB A ÓTICA DA SAÚDE DO TRABALHADOR

3 PROPOSIÇÃO 102

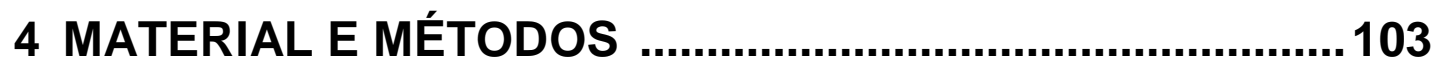

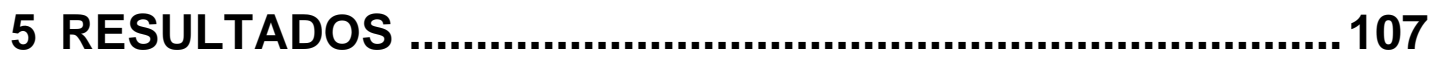

6 DISCUSSÃO ............................................................. 121

6.1 GLOBALIZAÇÃO E QUALIDADE DE VIDA NO TRABALHO REPERCUSSÕES PARA A EMPRESA E PARA

O TRABALHADOR 121

6.2 A ODONTOLOGIA NA INDUSTRIA E O PANORAMA DA ODONTOLOGIA E DA SAÚDE BUCAL NO BRASIL ...................129

6.3 IMPORTÂNCIA DA SAÚDE BUCAL .................................... 139

6.3.1 ASPECTO PSICOLÓGICO E COMPORTAMENTO SOCIAL ..................139

6.3.2 ALGUNS PROBLEMAS QUE OCORREM NA CAVIDADE BUCAL..........140

6.3.2.1 CÁRIE DENTÁRIA .............................................................. 140

6.3.2.2 DENTES COM ALTERAÇÕES PULPARES ..................................141

6.3.2.3 DENTES COM ALTERAÇÕES PERIAPICAIS ................................142 
6.3.2.4 DOENÇA PERIODONTAL ………………………………….....143

6.3.2.5 CIRURGIAS ODONTOLÓGICAS - EXODONTIAS .........................145

6.3.2.6 DESORDENS TÊMPORO- MANDIBULARES .................................146

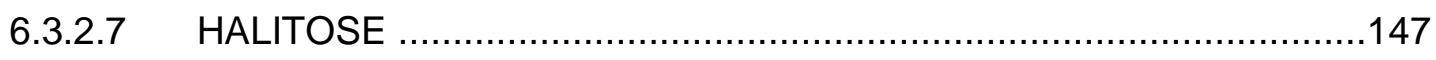

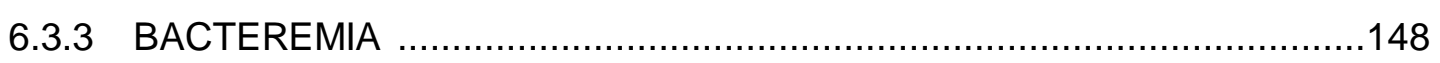

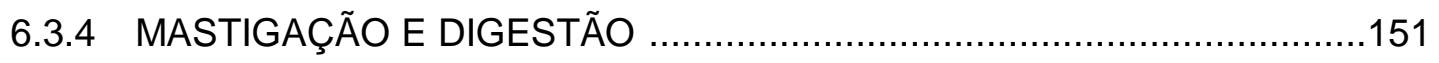

6.3.5 ALGUNS ASPECTOS FONOAUDIOLÓGICOS ………......................152

6.4 ABSENTEÍSMO POR CAUSA ODONTOLÓGICA ........................153

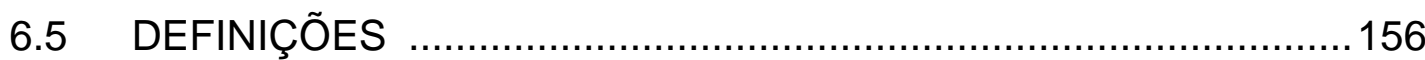

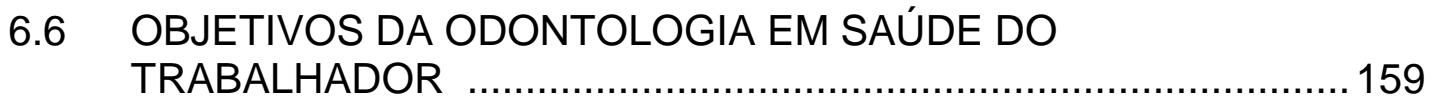

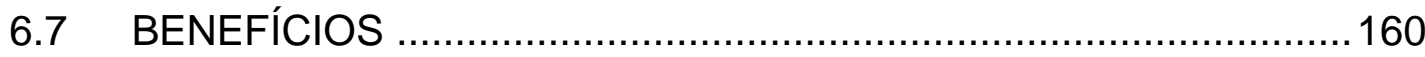

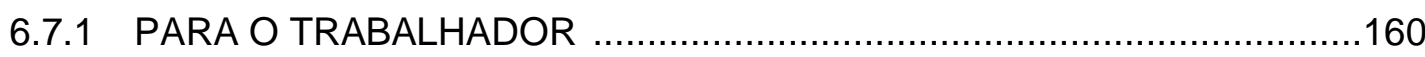

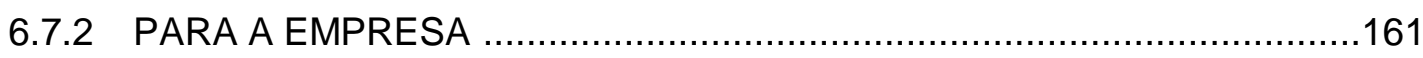

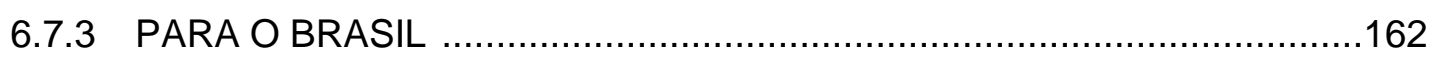

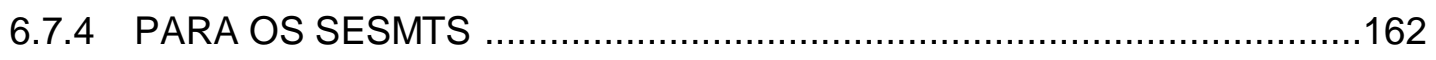

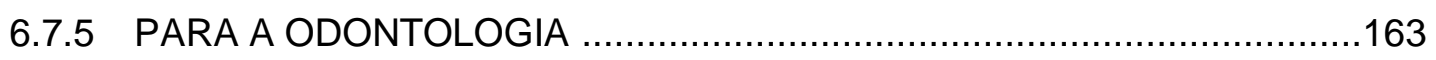

6.8 POLÍTICA DE SAÚDE DA EMPRESA E POLÍTICA DE ODONTOLOGIA EM SAÚDE DO TRABALHADOR

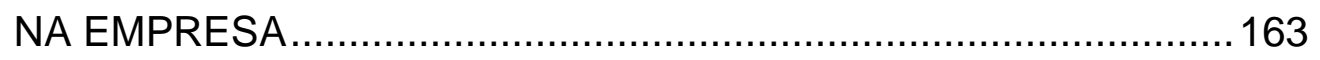

6.9 FUNÇÕES DO CIRURGIÃO-DENTISTA DO TRABALHO ..............169

6.9.1 ORGANIZAÇÃO DO SERVIÇO DE ODONTOLOGIA EM SAÚDE DO TRABALHADOR NA EMPRESA

6.9.1.1 CENSO ODONTOLÓGICO E VIGILÂNCIA EPIDEMIOLÓGICA ..

6.9.1.2 O LOCAL DE TRABALHO, O PROCESSO DE FABRICAÇÃO E AS FUNÇÕES DOS EMPREGADOS ......................180

6.9.1.3 LEVANTAMENTOS DE CAMPO PARA ANÁLISE PROFISSIOGRÁFICA

6.9.1.4 PARTICIPAÇÃO NOS PROGRAMAS DE ERGONOMIA DA EMPRESA 184

6.9.1.5 OS EXAMES ODONTOLÓGICOS E O PRONTUÁRIO EM ODONTOLOGIA EM SAÚDE DO TRABALHADOR 188

6.9.1.6 SUPERVISÃO DAS FACILIDADES DE TREINAMENTO DE PRIMEIROS-SOCORROS E NORMAS DE SEGURANÇA 195

6.9.1.7 PROGRAMA DE SAÚDE BUCAL DA EMPRESA (ODONTOLOGIA PREVENTIVA, EDUCAÇÃO EM SAÚDE BUCAL E PROMOÇÃO DE SAÚDE) E PREVENÇÃO, DIAGNÓSTICO E TRATAMENTO DOS ACIDENTES DO TRABALHO E DAS DOENÇAS PROFISSIONAIS .195 
6.9.1.8 ODONTOLOGIA RESTAURADORA, CURATIVA OU ASSISTENCIAL

6.9.1.9 PARTICIPAÇÃO NA COMISSÃO INTERNA DE PREVENÇÃO DE ACIDENTES (CIPA)

6.9.1.10 ACONSELHAMENTO À GERÊNCIA DA EMPRESA EM TODO ASSUNTO RELACIONADO COM A SAÚDE DO TRABALHADOR ...203

6.9.1.11 AVALIAÇÃO E/OU AUDITORIA NO CAMPO DA ODONTOLOGIA ....203

6.9.1.12 PERÍCIA, NO CAMPO DA ODONTOLOGIA EM SAÚDE DO TRABALHADOR, NA QUALIDADE DE PERITO DO JUÍZO OU ASSISTENTE TÉCNICO 205

6.10 ANÁLISE DOS QUESTIONÁRIOS 217

7 CONCLUSÕES 219 ANEXOS 221 


\section{LISTA DE FIGURAS}

Figura 1 Triângulo de responsabilidade sobre a saúde do trabalhador

Figura 2 Freqüência de acidentes de trabalho registrados e empregados segurados no Brasil de 1970 a 1997.

Figura 3 Porcentagem de empregados acidentados no Brasil de 1970 a 1997.

Figura 4 Empresas que possuem Serviço Especializado em Segurança e Medicina do Trabalho

Figura 5 Profissionais que compõem as equipes do SESMT 119

Figura $6 \quad$ Opiniões sobre a saúde bucal..................................... 119

Figura $7 \quad$ Existência de serviço odontológico na empresa............... 120

Figura $8 \quad$ Modalidades de serviço odontológico da empresa........... 120

Figura 9 Opiniões sobre a condição de saúde bucal dos funcionários........................................................ 120

Figura 10 Mapa político da República Federativa do Brasil............. 167

Figura 11 Triângulo epidemiológico...................................... 167

Figura 12 História natural e possíveis barreiras à doença humana... 168 


\section{LISTA DE TABELAS}

Tabela 1 Índices de acidentes do trabalho ocorridos no Brasil

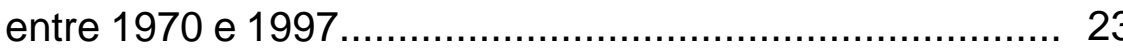

Tabela 2 Freqüência e porcentagem da distribuição da população pelas regiões geográfica. Brasil, 1997............................... 133

Tabela 3 Freqüência e porcentagem da distribuição dos CDs pelas regiões geográficas. Brasil, 2000

Tabela 4 Concentração de CDs por habitantes, nas regiões geográficas. Brasil, 2000

Tabela 5 Indicativos positivos de saúde bucal, segundo grupo etário, Brasil, zona urbana, 1986

Tabela 6 Índice CPOD e seus componentes, segundo grupo etário, Brasil, zona urbana, 1986

Tabela $7 \quad$ Porcentagem de pessoas edêntulas, de pessoas que necessitam de prótese total e tratamento para doença periodontal, segundo grupo etário, Brasil, zona urbana, 1986 


\section{LISTA DE QUADROS}

Quadro 1 Principais causas de acidentes do trabalho e suas

porcentagens ........................................................... 209 


\section{LISTA DE ANEXOS}

Anexo 1 Recomendação n. ${ }^{\circ} 112$ - Recomendação sobre os Serviços de Medicina do Trabalho nos locais de trabalho da IOT.

Anexo 2 Convênio n. ${ }^{\circ} 161$ - Convênio sobre os Serviços de Saúde do Trabalho da IOT.

Anexo 3 Recomendação N. ${ }^{\circ} 171$ - Recomendação sobre os Serviços de Saúde do Trabalho da IOT.

Anexo 4 NR 4 - Serviços Especializados em Engenharia de Segurança e em Medicina do Trabalho .

Anexo 5 Questionário encaminhado às empresas ....

Anexo 6 Portaria $\mathrm{n}^{\circ}$ 10, de 6 de abril de 2000 do Ministério do Trabalho e Emprego .............................................. 254

Anexo $7 \quad$ Ficha de avaliação da saúde bucal - OMS (1997)............. 263

Anexo 8 Sugestão de Prontuário em Odontologia em Saúde do Trabalhador

Anexo 9 Manifestação Bucal de Doenças Profissionais de acordo com agente e ocupação. (adaptado de Schour e Sarnat)

Anexo 10 Relação das situações que dão direito ao auxílio

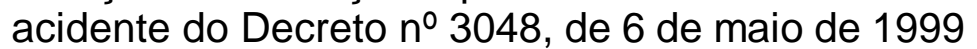

Anexo 11 Lista de Doenças relacionadas ao Trabalho da Portaria 1339, de 18 de novembro de 1999

Anexo 12 Protocolos médicos do Grupo 11 de doenças do aparelho digestivo que podem ser relacionadas com o trabalho da Resolução INSS/DC/n010, de 23 de dezembro de 1999 


\title{
LISTA DE ABREVIATURAS E SIGLAS
}

\author{
ABRASPE .........Associação Brasileira dos Serviços Assistenciais de Saúde \\ Próprios de Empresas \\ ACD ................Atendente de Consultório Dentário \\ ADA ….............Associação Dentária Americana \\ AIDS ................ Síndrome da Imunodeficiência Adquirida \\ APCD ..............Associação Paulista de Cirurgiões-Dentistas \\ ATM …............Articulação Têmporo- Mandibular \\ BBO ...............Bibliografia Brasileira de Odontologia \\ $\mathrm{C}+\mathrm{Ei}$.................dentes Cariados mais com Extração indicada \\ CAT ….............. Comunicação de Acidentes do Trabalho \\ CCQ ................ Círculos de Controle de Qualidade \\ CD ....................irurgião-Dentista \\ CEQ ................Controle Estatístico da Qualidade \\ CIEFAS ............ Comitê de Integração de Entidades Fechadas de Assistência \\ à Saúde \\ CIESP ..............entro das Industrias do Estado de São Paulo \\ CIPA …….......Comissão Interna de Prevenção de Acidentes \\ CLT .................Consolidação das Leis Trabalhistas \\ CPITN .............(ICNTP) Índice Comunitário de Necessidade de Tratamento \\ Periodontal) \\ CPOD .............. Índice de Dentes Cariados, Perdidos e Obturados
}




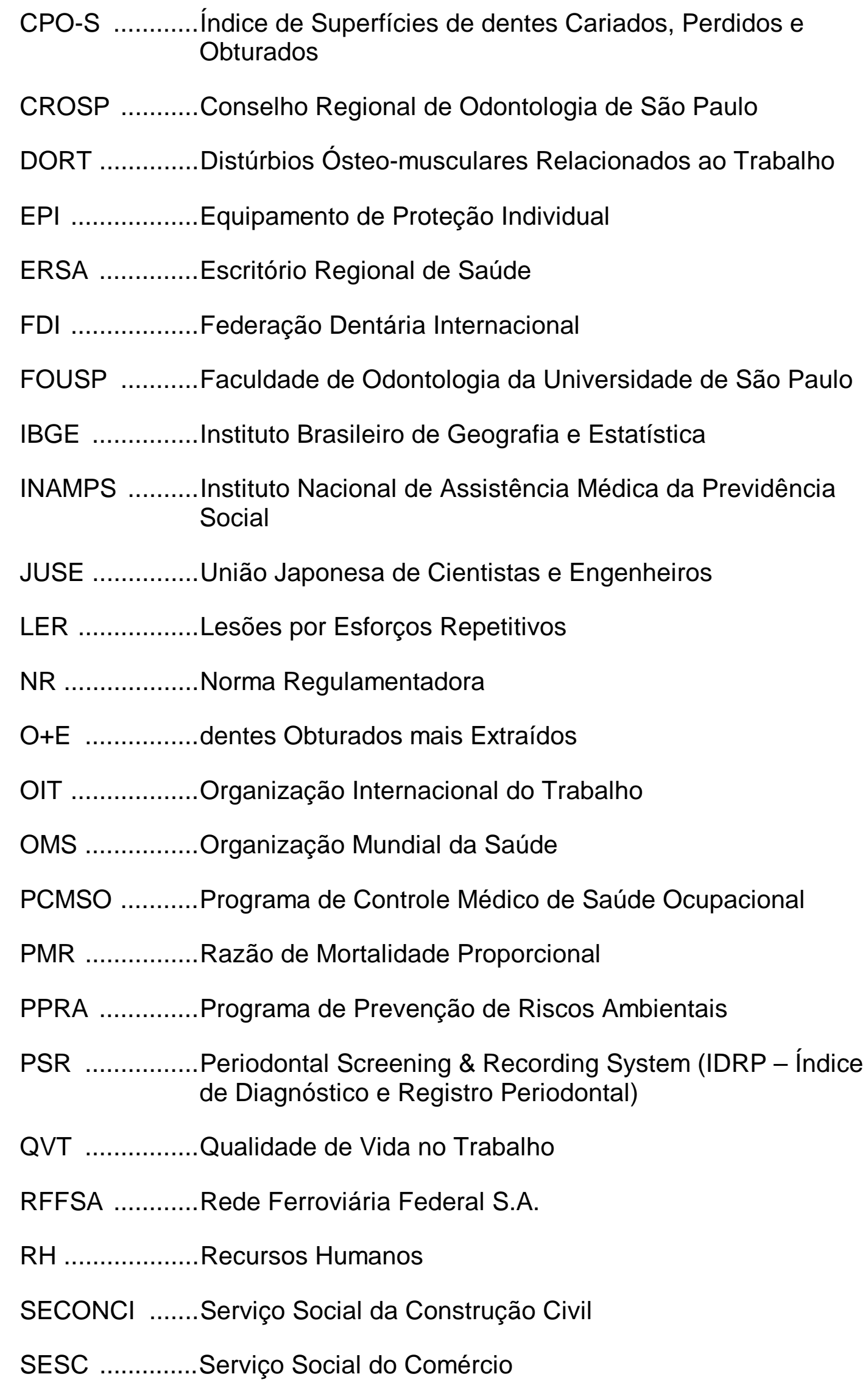




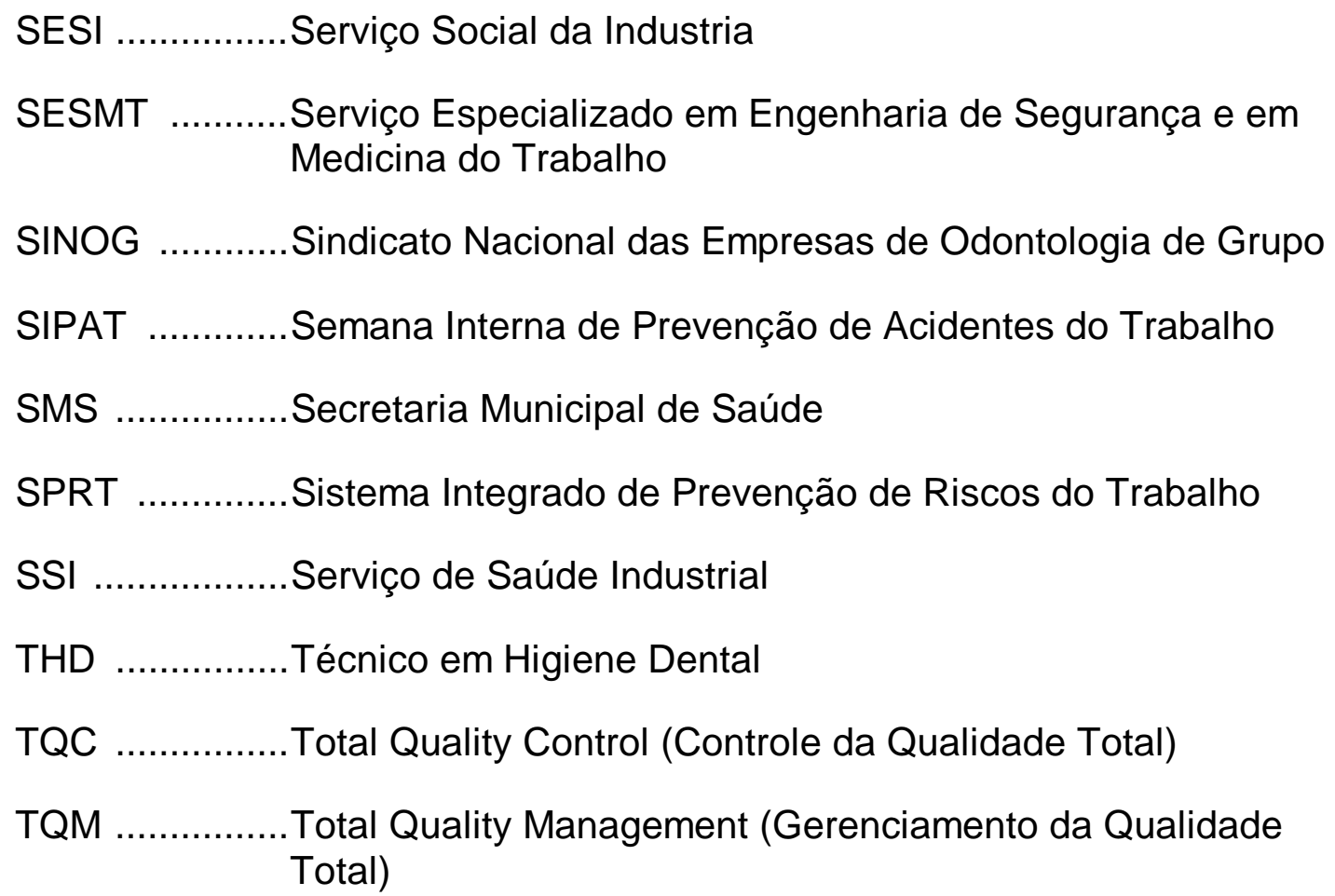




\title{
RESUMO
}

\section{A ODONTOLOGIA EM SAÚDE DO TRABALHADOR COMO UMA NOVA ESPECIALIDADE NA ODONTOLOGIA: DEFINIÇÃO DO CAMPO DE ATUAÇÃO E FUNÇÕES NA EQUIPE DE SAÚDE DO TRABALHADOR}

\begin{abstract}
Atualmente, as empresas brasileiras enfrentam novos desafios advindos do reflexo da globalização na economia. A competitividade, tanto na área de produtos quanto na de serviços, desafia as empresas a aumentarem sua produtividade e qualidade. Neste cenário, os recursos humanos são cada dia mais valorizados, e os empresários utilizam programas para melhorar as condições de trabalho e de saúde dos trabalhadores. Programas de Ergonomia, Qualidade Total, Qualidade de Vida no Trabalho, ações da equipe de Saúde do Trabalhador e inúmeros outros benefícios, como por exemplo assistência odontológica, visam melhorar as condições de competitividade da empresa. $\mathrm{Na}$ maioria das empresas, o cirurgião-dentista não participa da composição da equipe de segurança e saúde no trabalho. Por meio de levantamento da literatura de 1917 ao ano 2000, verificou-se a importância da Odontologia, não apenas para tratamentos, mas também como parte integrante da equipe de Saúde do Trabalhador. O presente estudo destacou principalmente uma visão mais detalhada da evolução, atuação e conceito da Odontologia em Saúde do Trabalhador, permitindo a delimitação desta nova área de atuação do cirurgião-dentista. Foram discutidas a influência de algumas doenças bucais sobre a saúde do trabalhador e suas conseqüências, como aumento dos índices de absenteísmo, de produtividade e de riscos de acidentes de trabalho. Sugere-se uma definição para a Odontologia em Saúde do Trabalhador, seus objetivos, política e benefícios para o trabalhador, para a empresa, para o Brasil, para a equipe de Segurança e Saúde no Trabalho e para a Odontologia. Pela análise de 10 questionários aplicados em empresas de grande porte do Estado de São Paulo, concluiu-se que é necessário um trabalho de esclarecimento voltado às empresas, aos trabalhadores, ao governo, aos sindicatos, aos profissionais de Saúde do Trabalhador e à classe profissional odontológica, para conscientizar todos os segmentos envolvidos sobre a importância da atuação do cirurgião-dentista do trabalho. Algumas funções do cirurgião-dentista do trabalho especialista em Odontologia em Saúde do Trabalhador seriam a prevenção, o diagnóstico e o tratamento das manifestações bucais das doenças profissionais, as avaliações técnicas de tratamentos odontológicos, as perícias no campo trabalhista e cível, e a colaboração com a equipe de segurança e saúde no trabalho para melhorar a sua atuação e atingir os seus objetivos. Contudo, como toda nova área, é imprescindível que novas pesquisas voltadas ao assunto sejam realizadas, pois muitas questões ainda
\end{abstract}


carecem de elucidação e/ou aprofundamento. Fica, porém, a certeza de que a atuação na área de Odontologia em Saúde do Trabalhador é de competência do cirurgião-dentista e deve, a curto prazo, tornar-se uma especialidade da Odontologia. 


\section{INTRODUÇÃO}

Nas últimas décadas, temos acompanhado muitas mudanças, como a queda do muro de Berlim, o fim do socialismo radical e a internacionalização do comércio com a Globalização da Economia - que tem como modelo a livre circulação de capitais, de mercadorias e de trabalhadores (Silva, 1999).

Com a globalização da economia ocorreu um aumento da competitividade mundial tanto na área de produtos quanto na de serviços. Isto gerou a necessidade de as empresas nacionais aumentarem a sua produtividade e a qualidade de seus produtos e serviços, a fim de diminuírem os custos operacionais e não serem "jogadas" para fora do mercado pelas empresas multinacionais ou transnacionais, pois o padrão de competitividade passou de quantidade para qualidade, despadronização e personalização da produção.

Para obter este êxito e sobreviver, os administradores estão se dando conta, cada vez mais, da importância dos recursos humanos como o bem mais importante da empresa, ou seja, o Homem como sendo a peça fundamental do sistema de produção. 
Os empresários partidários desta idéia implementam medidas que beneficiam as condições do sistema de produção, adaptando-o para facilitar a produtividade e a satisfação dos colaboradores.

A Ergonomia, os programas de Qualidade Total, de Qualidade de Vida no Trabalho, as ações das Equipes de Saúde do Trabalhador e a promoção de benefícios assistenciais, como por exemplo o atendimento odontológico aos funcionários, são alguns dos meios utilizados por esses empresários para melhorar as condições de competitividade da empresa no mercado globalizado.

A ergonomia vem sendo utilizada na adaptação do trabalho com relação aos instrumentos, equipamentos, postos de trabalho e ambiente, e ao homem com suas características, restrições, valores e limitações, procurando um aumento da produtividade e da qualidade sem levar à doença, que é um subproduto do sistema de produção moderno que tem acometido muitos trabalhadores no Brasil e no mundo.

$\mathrm{Na}$ atualidade, muito se tem falado sobre Qualidade Total (base da produtividade e da competitividade), e autores como Deming (1990), Juran (Green, 1995), Crosby (Bouer, 1997) e Ishikawa (Green, 1995) são os grandes nomes desta filosofia, que visa a melhoria do processo de produção e de qualidade dos produtos e serviços oferecidos pela empresa.

Os resultados dos programas de Qualidade de Vida no Trabalho (QVT) vêm da inter-relação de diversos fatores físicos, tecnológicos e sociopsicológicos que afetam a cultura da empresa e o clima organizacional, 
refletindo-se no bem-estar do trabalhador e, conseqüentemente, na produtividade e na qualidade dos produtos e serviços da empresa.

Fernandes (1996) coloca como fatores-chave do sucesso empresarial as Condições de Trabalho, de Saúde, de Moral, de Compensação, de Participação, de Comunicação, de Imagem da Empresa, das Relações chefe/subordinado e da Organização do Trabalho.

Como citado acima, a Qualidade de Vida no Trabalho decorre união de vários fatores, sendo um deles a saúde do trabalhador. Dentro das ações de Saúde do Trabalhador, a Promoção de Saúde nas empresas é um aspecto que tem tido grande ênfase nos últimos anos. São exemplos dessas ações a implantação de programas de exercícios físicos - como a ioga -, além de outros benefícios - como a Odontologia Assistencial - que têm como objetivo o bem-estar do trabalhador que, mais satisfeito e saudável, produz mais e com melhor qualidade.

A alta incidência de acidentes de trabalho ainda é uma grande e constante preocupação dos empresários e da equipe de saúde do trabalhador, apesar das estatísticas oficiais demonstrarem ter diminuído nos últimas décadas.

O SESMT (Serviço Especializado em Engenharia de Segurança e em Medicina do Trabalho) que tem, como um dos seus principais objetivos a diminuição dos acidentes do trabalho atualmente, pela legislação, não conta com a participação, em sua equipe, de cirurgiões-dentistas.

Atualmente, a odontologia é vista apenas como mais um benefício de caráter assistencial ao colaborador da empresa, com a finalidade de 
diminuir 0 alto índice de absenteísmo decorrente de problemas odontológicos, - por meio de procedimentos curativos no serviço próprio da empresa, ou de empresa contratada para tal nas várias constituições jurídicas. Entretanto, hoje há informações sobre a ocorrência de acidentes de trabalho cuja causa básica foram os problemas odontológicos.

Assim, o presente estudo originou-se do desenvolvimento da área denominada Saúde do Trabalhador na última década. Esta área é caracterizada caracterizado por ter uma filosofia mais abrangente que a sua antecessora, denominada Saúde Ocupacional. Por outro lado, também existe a necessidade de complementar as equipes dos SESMTs, incluindo nelas a participação do cirurgião-dentista (CD) do trabalho para prevenir os Acidentes do Trabalho e as Doenças Profissionais, o que proporcionará uma série de vantagens para o empregado, para a empresa e para a nação. Essas vantagens compreendem desde o aumento da motivação do empregado - por estar mais saudável e trabalhando com mais segurança até o aumento da produtividade, da qualidade e da competitividade dos produtos e serviços da empresa. 


\section{REVISÃO DA LITERATURA}

Este capítulo será dividido em três partes: primeiro apresentaremos um histórico do homem no trabalho e a evolução do sistema de produção até o século XX, no qual a relação trabalho-homem será analisada. Em um segundo momento, mostraremos o histórico dos primeiros estudos sobre saúde do homem no trabalho até a filosofia atualmente vigente sobre saúde do trabalhador. Para tanto, seguiremos uma seqüência didática - que nem sempre respeitará a seqüência cronológica -, a fim de manter a lógica e a intelecção do texto. E, na terceira parte, abordaremos a odontologia sob a ótica da saúde do trabalhador, na qual descreveremos a relação odontologia-trabalho, seguindo a ordem cronológica, para demonstrar a evolução dos conceitos e dos trabalhos científicos sobre o assunto.

\subsection{BREVE HISTÓRICO DO HOMEM NO TRABALHO E A EVOLUÇÃO DO SISTEMA DE PRODUÇÃO ATÉ $O$ SÉCULO XX}

Historicamente, o trabalho sempre foi visto negativamente. A origem da palavra TRABALHO vem do latim Tripalium, que era um instrumento 
agrícola feito de três paus aguçados, algumas vezes munido de pontas de ferro, que foi utilizado como instrumento de tortura (Albornoz, 1995; Gonçalves \& Wise, 1997).

No primeiro estágio da economia, o homem vivia do extrativismo vegetal e animal, pois colhia frutos e vegetais da natureza e caçava e pescava os animais que se reproduziam e cresciam sem o seu auxílio (Albornoz, 1995).

Quando acabavam os recursos para a sua sobrevivência, partia para outro local - caracterizando sua condição de nômade -, e o trabalho servia apenas para a subsistência. Em seguida passou a desenvolver atividades agrícolas o que, de acordo com Albornoz (1995), teria sido uma descoberta casual: após um incêndio na floresta, o grupo teria observado que as plantas cresciam novamente das cinzas, a partir das sementes.

Continuando a evolução, alcançou a fase do artesanato. $\mathrm{Na}$ Antigüidade já havia povos, como os fenícios, dedicados ao comércio e, na Idade Média, procurou aplicar à produção os conhecimentos que já detinha sobre a natureza e os fenômenos físicos. Tais conhecimento levaram-no ao desenvolvimento do saber e novas tecnologias surgiram, culminando com a Era Industrial, na qual surgiram a máquina a vapor - patenteada por James Watt em 1769 -, a máquina de fiar (Spinning-Jenny) - patenteada por Hargreaves em 1770 -, o filatório de Crompton - introduzido em 1779 -, e o tear mecânico de Cartwright, em 1785 (Huberman, 1984).

O século XIX caracterizou-se pela utilização da eletricidade e do motor de combustão interna. No século XX, a Revolução Industrial - ou 
terceira onda da Revolução Industrial - trouxe a invenção do transistor, que permitiu a execução de tarefas com consumo mínimo de energia, e o desenvolvimento da da informática e da eletrônica (Gonçalves,1994).

No modelo de produção artesanal o artesão podia parar para descansar, caso quisesse fazê-lo. Sua relação com o trabalho era prazerosa pois tinha visão de todo o processo e sabia conduzi-lo bem. Podia parar durante o tempo que quisesse para atividades de lazer, como caminhar e conversar com os vizinhos, sempre que sentisse necessidade (Albornoz, 1995).

O trabalhador era livre para organizar o seu trabalho, planejando e determinando a técnica a ser utilizada e o tempo que despenderia para executá-lo. Como não existia a divisão do trabalho, este era um meio de desenvolver as habilidades do indivíduo, e era considerado um divertimento (Albornoz, 1995).

Na Era Industrial, o que vemos é justamente o oposto do modelo artesanal, pois na linha de montagem não se pode parar por causa do ritmo e do controle da produção e da qualidade. Como um exemplo clássico, Silva (1999) cita o filme Tempos Modernos, de Charles Chaplin, de 1936, no qual o diretor demonstra, de maneira muito oportuna, as possíveis conseqüências da especialização e da divisão do trabalho, apresentando uma linha de produção onde não era permitido o descanso nem a comunicação entre os colegas.

Assim, o trabalhador não tem prazer na execução do trabalho, só conhece a sua parte e não o todo, não tem liberdade para planejar a técnica 
que deve utilizar, nem pode determinar o ritmo e o tempo de produção do seu trabalho. O trabalho é "desvinculado" do lazer, mas não se pode separálo totalmente deste último, do prazer e da cultura. Exemplo disto é o hobby, que é a atividade que fazemos porque gostamos, nas horas vagas daquele trabalho insatisfatório e extenuante (Albornoz, 1995).

Como relatam Huberman (1984) e Singer (1985), no início do século $\mathrm{XVI}$, no putting-out system, o capitalista não permitia o acesso dos artesãos ao mercado para a compra de matérias-primas e a venda de seus excedentes, mas eles ainda detinham o controle do processo de produção. A figura do capitalista era, desta forma, imprescindível para a comercialização da produção, mas os trabalhadores (produtores) ainda não estavam agrupados em um mesmo local de trabalho. Esse "agrupamento" do conjunto de trabalhadores ocorreu - segundo Marglin (apud Decca, 1996) porque o Sistema de Fábrica possibilita a disciplina e a hierarquização da produção, surgindo daí a relação de trabalho (patrão X empregado).

Enquanto no putting out system os trabalhadores estavam dispersos - o que trazia, para os capitalistas, problemas como o desvio de parte da produção, a falsificação dos produtos, a utilização de matérias-primas de qualidade inferior à fornecida pelo capitalista -, no Sistema de Fábrica a hierarquia, a disciplina e a vigilância submeteram os trabalhadores ao regime de trabalho ditado pelos mestres e contra-mestres - originando o domínio capitalista sobre o processo de trabalho (Decca, 1996).

Dickson (1978) apud Decca (1996) cita quatro motivos para a constituição do Sistema de Fábrica: a necessidade dos comerciantes de 
controlar e comercializar o processo de produção dos artesãos; a maximização da produção, com aumento da produtividade (número de horas, velocidade e ritmo de trabalho); o controle da inovação tecnológica de forma a que somente fosse utilizada para a acumulação de capital; e a necessidade de organização, com a presença do empresário capitalista.

Com o aprimoramento das máquinas e do Sistema de Fábrica foi possível o desenvolvimento da tecnologia, que não apenas aumentou a produtividade, mas também possibilitou o controle, a disciplina, a hierarquização e a divisão do processo de trabalho. A expansão desse mercado capitalista se deu a partir da produção e do crescente consumo dos bens de produção (Huberman, 1984; Decca, 1996).

Huberman (1984) relata que na França, no século XVII, Colbert, que ocupou vários postos no gabinete francês, procurava atrair bons artesãos estrangeiros oferecendo-Ihes privilégios, moradia gratuita, isenção de impostos, e muitas vezes chegou a raptá-los. Outros países não só concediam o monopólio aos inventores, como davam prêmios àqueles que desenvolvessem novos métodos para a indústria.

Desde o início da Revolução Industrial os trabalhadores eram menosprezados, pois adaptava-se o homem à máquina ou à função, sem que fossem levados em consideração as características individuais, os fatores fisiológicos e os problemas decorrentes do ambiente laboral (Huberman, 1984).

Para Mendes (1980) e Huberman (1984), as máquinas não tornaram o trabalho mais leve, mas pior. O capital empregado precisava ser 
aproveitado da forma mais eficiente possível, pois o empresário inteligente sabia que, com novas invenções surgindo, as máquinas que possuía poderiam tornar-se rapidamente obsoletas.

As jornada de trabalho eram longas - de cerca de dezesseis horas -, não havia um limite de horas, e o ritmo era acelerado, sempre sob as ordens do capataz. A mão-de-obra não qualificada (crianças e mulheres) e mais barata, máquinas sem proteção, pouca iluminação, má ventilação, precária higiene do local e ruídos altíssimos caracterizavam as péssimas condições de trabalho.

"Os capitalistas achavam que podiam fazer como bem entendessem com as coisas que lhes pertenciam ... Não era bem assim - como as máquinas representavam um investimento, e os homens não, preocupavam-se mais com o bem-estar das primeiras" (Huberman, 1984; Gonçalves \& Wise, 1997).

O Parlamento Britânico criou a Comissão de Inquérito, sob direção de Robert Peel e, em 1802, fez a "Lei de Saúde e Moral dos Aprendizes" que estabelecia o limite de doze horas de trabalho por dia, proibia o trabalho noturno, e tornava obrigatória a existência de ventilação nas fábricas, e a lavagem de suas paredes duas vezes ao ano (Nogueira, 1979).

Em 1816, John Moss, antigo capataz de aprendizes de uma fábrica de tecidos de algodão, no seu depoimento sobre as crianças, relatou que trabalhavam quinze horas diárias, em pé, sem cadeiras, tinham idade a partir de sete anos, e eram considerados aprendizes até os vinte e um anos e que, freqüentemente havia, muitos acidentes com essas crianças (Huberman, 1984). 
No início do século XX, Henry Ford introduziu a linha de montagem na indústria de automóveis, baseado na teoria de Frederick Taylor de Administração Científica do Trabalho. Taylor, estudando os tempos de realização das várias etapas de uma tarefa, estabeleceu os chamados tempos-padrão que eram, na sua concepção, a melhor maneira de realizar o trabalho. Este método "científico" para gestão das fábricas foi denominado organização científica do trabalho (Gonçalves \& Wise, 1997).

Nessa época, o estudo de movimentos realizado pelo casal Frank B. Gilbreth e Lilian M. Gilbreth também foi empregado na melhoria de métodos de trabalho (Barnes, 1977).

Para Taylor, o trabalhador era preguiçoso e não usava adequadamente os movimentos, o que levava a uma baixa produtividade. A idéia era simplificar ao máximo a produção, tornando as operações únicas e repetitivas, com o controle dos tempos e dos movimentos necessários à produção e aumentando a produtividade com a diminuição dos chamados "tempos-mortos" da indústria e a padronização dos componentes e produtos (Gonçalves \& Wise, 1997).

Gonçalves \& Wise (1997) lembram que o modelo taylorista-fordista intensificou divisão social do trabalho, pois separa as fases de concepção e execução do processo produtivo, propõe rigidez na hierarquia funcional e extremo controle e burocratização, favorecendo a desqualificação do trabalhador e reduzindo-o a um autômato repetidor de gestos mecânicos, sem criatividade, sentimento, desejo ou emoção na realização do seu trabalho. 
$\mathrm{E}$, até os nossos dias, aquilo que deveria ser elemento fundamental de desenvolvimento da pessoa humana passa a ser estranho ao seu eu íntimo. O trabalho passa a ser executado sem atrativo ou realização pessoal, apenas porque se precisa dele para se viver (Gonçalves, 1988).

"O homem que trabalha deseja não apenas receber remuneração devida pelo seu trabalho, mas deseja também que seja tomada em consideração, no próprio processo de produção, a possibilidade de que ele, ao trabalhar, ainda que seja numa propriedade comum, esteja cônscio de trabalhar "por sua conta". Essa consciência fica nele abalada ao encontrar-se num sistema de centralização burocrática excessiva, no qual o trabalhador se vê sobretudo como peça duma engrenagem num grande mecanismo movido de cima; $e$ ainda - por várias vezes - mais como um simples instrumento de produção do que como um verdadeiro sujeito do trabalho, dotado de iniciativa própria."

(http://www.vatican.va/holy_father/jo.../hf_jp-ii_enc_14091981_laborem-exercens_pó.htm).

Hoje, com a globalização da economia, a administração, que antes era baseada na valorização da estrutura, da tecnologia e do mercado, passa a ser baseada no uso da informação e na flexibilização dos processos, levando à reorganização do mundo do trabalho, com a redução da divisão social do trabalho e a maior exigência de qualificação do trabalhador. Este modelo permite maior participação do trabalhador no processo de produção, recuperando sua autonomia, iniciativa, criatividade e força de coesão social, valores estes fundamentais à dignidade do trabalho (Gonçalves, 1994; Gonçalves \& Wise, 1997). 


\subsection{DOS PRIMEIROS ESTUDOS SOBRE SAÚDE NO TRABALHO ATÉ A SAÚDE DO TRABALHADOR}

Quando falamos sobre a saúde do homem no trabalho, não podemos considerá-la separadamente do conceito de saúde explicitado pela Organização Mundial da Saúde - OMS - (Chaves, 1986). Devemos sim analisar como o ambiente laborativo pode alterar a saúde do trabalhador, e como agir para prevenir acidentes e doenças profissionais.

Nosso objetivo, neste item, é traçar um histórico sucinto que contemple desde a saúde no trabalho até a saúde do trabalhador, e mostrar como a abordagem interdisciplinar - quando se analisa a saúde do homem no trabalho - é importante para a melhora da saúde dos trabalhadores.

Nogueira (1979) coloca que, apesar de o trabalho ter surgido desde o aparecimento do primeiro homem na terra, a importância da saúde e o processo saúde $\mathrm{x}$ doença nos ambientes de trabalho foram por muito tempo ignorados.

Lembra-nos Mendes (1980) que Hipócrates (460-375 a.C.), no seu livro Ares, Águas e Lugares, descreveu com grande precisão o quadro clínico da intoxicação saturnina, apesar de omitir totalmente o ambiente de trabalho e a ocupação. Também deixou vários ensinamentos sobre as relações entre saúde e ambiente.

Alguns autores (Legge, 1936; Hunter, 1969 apud Nogueira,1979) relatam que em Basel, em 1556, Georg Bauer, mais conhecido como Georgius Agrícola (1494-1555), publicou o livro intitulado "De Re Metallica”, no qual apresenta diversos problemas decorrentes da extração de minerais 
argentíferos e auríferos destinados à fundição de prata e ouro. O livro dedica um capítulo aos acidentes de trabalho e às doenças mais comuns dos mineiros. Onze anos depois dessa publicação (1567), surgiu a primeira monografia sobre as relações entre trabalho e doença, escrita por Aureolus Theophrastus Bembastus von Hohenheim (1493-1541), conhecido como Paracelso.

Paracelso, por ter nascido e sido criado em um centro mineiro da Boêmia, pôde observar os métodos de trabalho e as substâncias manipuladas, bem como as doenças encontradas naqueles que exerciam tal atividade, em especial aquelas decorrentes da intoxicação por mercúrio (Nogueira, 1979).

Em 1700, em Modena na Itália, foi publicado o livro "De Morbis Artificum Diatriba" escrito pelo médico Bernardino Ramazzini (1633-1714), considerado hoje o Pai da Medicina do Trabalho. Nessa obra o autor descreve, com grande perfeição, doenças relacionadas a cinqüenta e quatro diferentes categorias profissionais. Também acrescenta às perguntas hipocráticas da anamnese a pergunta: "que arte exerce?", ou seja, "qual é a sua ocupação?" (Legge, 1936; Nogueira, 1979; Mendes, 1980; Ramazzini, 1992).

No prefácio do seu livro, Ramazzini (1992) escreveu uma dedicatória intitulada "o autor a seu livro":

“Estás ardendo de desejo, livro querido, ansioso para seguires teu caminho. Escuta, entretanto, meus conselhos paternais. Vou te dizer, em poucas palavras, qual é a sorte que te reserva o destino.

Como proclamas que vais ensinar uma matéria nova, os sábios acorrerão a ti ávidos e curiosos. 
Porém, mal terão eles lido duas pobres páginas,

te enviarão para plebéias quitandas,

onde se expõem à plebe

salsichas, sal ou outras especiarias.

Ó! não fiques decepcionado. É coisa freqüente

verem-se até imponentes Pandectas

transformar-se em cartuchos de embalagens

de peixe, pimenta ou cheiroso cumim.

Não te esqueças de que foste elaborado em escuras oficinas

e não em palácios de ricos,

nem em cortes brilhantes onde sábios médicos, sempre

pressurosos,

estendem a mão aos cozinheiros.

Pensando assim, creio eu, serás menos iludido

como não o seriam livros de títulos pretensiosos

se aqueles que te lerem te devolverem

para as oficinas onde nasceste." (1992)

Para Mendes (1980), Ramazzini, com este prefácio, deixa claro que

não tinha ilusões sobre a aceitação da sua obra, que só foi reconhecida, segundo Dória (1941), um século mais tarde.

Felton (1997) relata que, no século XVIII, Adam Smith, economista

escocês, em seu livro Inquérito sobre a natureza e as causas das riqueza

das nações, de 1776, citou o livro de Ramazzini (1992) desta forma:

"Quase todas as classes de artesãos estão sujeitas a alguma doença peculiar originada pela excessiva aplicação ao respectivo tipo de trabalho. Ramazzini, um eminente médico italiano, escreveu um livro especialmente dedicado a tais doenças" (Smith, 1980; Smith, 1776 apud Felton, 1997) .

Apesar de não ser médico, Smith (1980) analisou a possível conseqüência de trabalhar em excesso, quer na indústria, quer em outra atividade, da seguinte forma:

"A grande aplicação ao trabalho, quer físico quer mental, mantida durante vários dias seguidos é, na maior parte dos homens, seguida naturalmente por um enorme desejo de descanso, o qual, se não for combatido pela força ou por uma grande necessidade, é quase irresistivel. É a voz da natureza que reclama o alívio de alguma indulgência, às vezes de simples descanso, mas às vezes 
também de dissipação e diversão. Se não for obedecida, as conseqüências serão muitas vezes graves e, por vezes, fatais, e de tal sorte que, quase sempre, mais cedo ou mais tarde, acarretam consigo a doença peculiar de cada ofício. Se os patrões escutassem sempre os ditames da razão e da humanidade, teriam mais freqüentemente ocasião de moderar, que de exacerbar a aplicação de muitos dos seus trabalhadores. Creio que deve verificar-se, em todas as espécies de trabalho, que o homem que trabalha com a moderação necessária para conseguir manter uma atividade contínua não só preserva a sua saúde por mais tempo, como, no decurso de todo um ano, executa a maior quantidade de trabalho." (Smith, 1980)

Em um primeiro momento, a fiação e a tecelagem eram artesanais, apresentavam baixa produtividade, e o excedente era vendido em locais em que não havia esse tipo de produção. Com o advento da máquina de fiação e tecelagem, e da máquina a vapor no período da Revolução Industrial (1760-1830), as cidades foram se desenvolvendo a partir das indústrias, pelo aumento da velocidade de produção (Nogueira, 1979).

Geralmente o dono da indústria não era o tecelão (artesão), pois quem detinha o capital era o burguês - desta forma teve início a relação de trabalho capitalista (patrão $x$ empregado). A mão-de-obra não era qualificada, e era composta, freqüentemente, por mulheres que recebiam salários menores e por crianças - que ou eram compradas em orfanatos ou eram obrigadas a trabalhar para ajudar na renda familiar (sobrevivência). As condições de trabalho não eram boas. As máquinas com correias expostas, sem proteção, causavam inúmeros acidentes, e não havia limite de horas de trabalho - o que, em virtude do cansaço, aumentava o risco de acidentes de trabalho. A iluminação insuficiente era muitas vezes feita através de bicos de gás, o ambiente de trabalho era fechado, com pouca ventilação, e as máquinas provocavam ruídos elevadíssimos que causavam, além da surdez, 
a impossibilidade de comunicação facilitando a ocorrência de acidentes. A higiene era precária, o que permitia a disseminação tanto de doenças nãoocupacionais, como o tifo europeu - que foi chamado de "febre das fábricas" -, quanto de doenças de origem ocupacional (Dória, 1941; Mendes, 1980).

Desta forma, conta-nos Mendes (1980) que o Parlamento Britânico, preocupado com a grave situação do grande número de acidentes de trabalho - com mortes e mutilações -, criou a Comissão de Inquérito, sob direção do Dr. Robert Peel que, em 1802, conseguiu a aprovação da "Lei de Saúde e Moral dos Aprendizes", que estabelecia o limite de 12 horas de trabalho por dia, proibia o trabalho noturno, e tornava obrigatórias a ventilação das fábricas e a lavagem de suas paredes duas vezes ao ano (Mendes, 1980).

Em 1830, Robert Dernham - proprietário de uma fábrica preocupado com as condições de trabalho de seus empregados, procurou 0 Dr. Robert Baker, famoso médico inglês, que sugeriu-lhe que contratasse um médico para visitar diariamente o local de trabalho, estudar a sua influência sobre a saúde de seus empregados e que, quando da constatação de algum problema, trabalhador fosse afastado de sua atividade profissional. $O$ proprietário contratou o próprio Baker para o cargo, inaugurando o primeiro serviço médico industrial (Mendes, 1980; Mendes \& Dias, 1991).

Mendes (1980) relata que, em 1831, uma comissão parlamentar de inquérito, sob a chefia de Michael Saddler, elaborou um relatório sobre a crueldade do homem para com o homem nas indústrias, o que culminou com o "Factory Act", em 1833. Esse foi o primeiro instrumento legal eficiente no 
que concerne à saúde do trabalhador, e determinava que todas as empresas têxteis que utilizassem força hidráulica ou a vapor estavam proibidas de ter menores de dezoito anos no trabalho noturno, além de restringir a carga horária dos trabalhadores a doze horas por dia e sessenta e nove horas por semana. Também foi determinada a idade mínima de nove anos para ingresso no trabalho, e as fábricas eram obrigadas a ter escolas que deveriam ser freqüentadas por todas as crianças abaixo de treze anos de idade, e um médico para acompanhar o desenvolvimento físico dos pequenos trabalhadores.

Em 1950, a Organização Internacional do Trabalho (OIT) e a Organização Mundial da Saúde (OMS) elaboraram os objetivos da Saúde Ocupacional, que são:

a proteção da saúde e bem-estar do trabalhador contra os riscos e condicionamentos do ambiente de trabalho;

$\checkmark$ a colocação do trabalhador numa atividade, de acordo com sua capacidade física e emocional, de modo a poder realizá-la sem perigo para ele e seus colegas, e sem dano à propriedade;

$\checkmark$ o provimento de socorros médicos de emergência para os acidentes e doenças ocupacionais e não-ocupacionais, e de definitivos cuidados e reabilitação daqueles com doenças ou seqüelas ocupacionais;

$\checkmark$ a manutenção da saúde do trabalhador através de atividades promocionais, procedimentos específicos de medicina preventiva, e freqüente revisão do estado de saúde;

$\checkmark$ o controle dos riscos potenciais à saúde inerentes à operação de trabalho (Nogueira, 1979; Nefussi, 1979; Mendes, 1980). 
Após a 2a Guerra Mundial, o ônus provocado pela perda de vidas por acidentes do trabalho e por doenças ocupacionais começou a ser mais sentido pelos empregadores - que queriam mão-de-obra produtiva -, e pelas companhias de seguros - pelos custos de pesadas indenizações por incapacidades provocadas pelo trabalho. Concomitantemente, a tecnologia industrial evoluiu de forma acelerada, com o desenvolvimento de novos processos industriais, produtos químicos e novo rearranjo da divisão internacional do trabalho, levando ao surgimento de novas doenças profissionais que se constituíram em desafio à medicina do trabalho. Esses fatores colaboraram para uma relativa impotência da medicina do trabalho em intervir e sanar os problemas de saúde causados pelo processo de produção. Para resolver esse impasse, a atuação médica foi ampliada, interagindo com o ambiente com o instrumental de outras disciplinas e de outras profissões, o que propiciou o surgimento da Saúde Ocupacional dentro das grandes empresas (Mendes \& Dias, 1991).

No Brasil, lembram Mendes (1980) e Mendes \& Dias (1991), a Saúde Ocupacional surge como um ramo da saúde ambiental - como na Faculdade de Saúde Pública da USP - e também como instituições - como a Fundação Jorge Duprat Figueiredo de Segurança e Medicina do Trabalho (FUNDACENTRO), criada pela Lei 5.161, de 21/10/66 e instalada em 1969.

A responsabilidade pelos objetivos preconizados pela Organização Internacional do Trabalho (OIT) / Organização Mundial da Saúde (OMS) é do Estado (Ministério do Trabalho) - com a elaboração legislativa e fiscalização dos preceitos de segurança e saúde do trabalhador -, da Empresa - 
cumprindo e fazendo cumprir as determinações de segurança e saúde do trabalhador - e do Trabalhador (Sindicato) - cumprindo as determinações da Portaria 3214 de 08/06/1978 (Normas Regulamentadoras - NRs), como pode ser observado na Figura 1 (Nefussi, 1979).

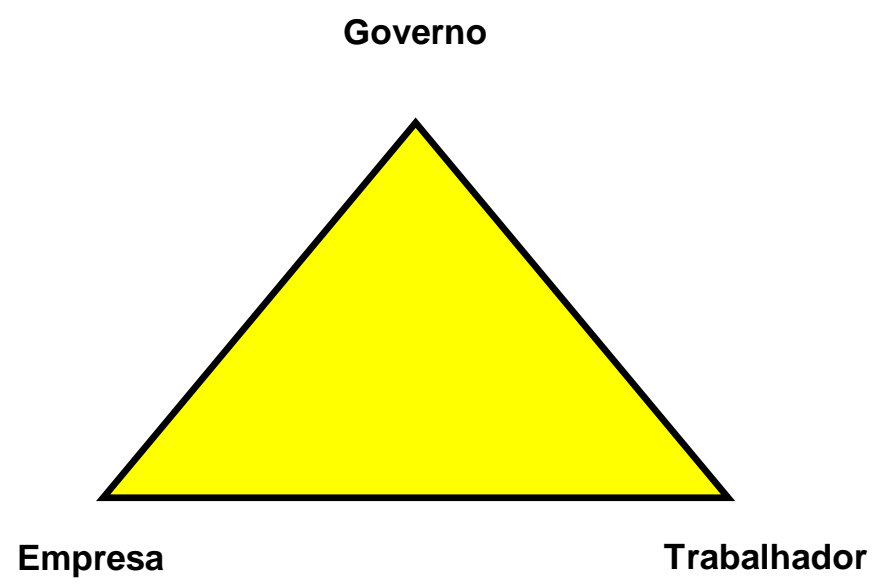

Fonte: Nefussi, 1979

Figura 1 - Triângulo de responsabilidade sobre a saúde do trabalhador.

Mendes e Dias (1991) informam-nos que, na Legislação Brasileira, a regulamentação do capítulo V da Consolidação das Leis do Trabalho (CLT), reformulada na década de 70 , expressou nas normas a obrigatoriedade de equipes técnicas multidisciplinares nos locais de trabalho.

Em julho de 1972, a Portaria $3237 / 72$ obrigou todas as empresas nacionais a seguirem a Recomendação n 112 da OIT (Anexo 1), e a criarem serviços próprios de Higiene e Segurança do Trabalho de acordo com o número de empregados e o grau de periculosidade do trabalho. Isto serviu de proteção dos trabalhadores e abriu novo mercado de trabalho para os profissionais citados na legislação (Nogueira, 1979). 
Em 17/09/90, foi publicado a Portaria $n^{\circ} 11$, que versa sobre a composição do Serviço Especializado em Engenharia de Segurança e em Medicina do Trabalho, que é composto pelos seguintes especialistas:

1. Engenheiro de Segurança do Trabalho

2. Técnico de Segurança do Trabalho

3. Médico do Trabalho

4. Enfermeiro do Trabalho

5. Auxiliar de Enfermagem do Trabalho

Algumas empresas já contam com Psicólogos do Trabalho e Assistentes Sociais, mas poucas têm Cirurgiões-Dentistas do Trabalho em seu quadro.

O número de acidentes de trabalho cresceu desde o aparecimento da primeira máquina de fiar, deixando muitos mortos, e sobreviventes com várias seqüelas. Em nosso país os primeiros registros datam de 1959 e, nestes, estimava-se a ocorrência de um acidente por minuto nos principais centros industriais, resultando num total de 1.400 .000 acidentes por ano (Carvalho et al., 1965).

Carvalho et al. (1965) relatam que, em 1963, na Comarca de São Paulo, foram comunicados 38.567 acidentes de trabalho. Em 1970, havia 7.234.022 empregados segurados, e ocorreram 1.220.111 acidentes registrados $(16,75 \%)$, o que aumentou até 1975 , com 12.996 .796 empregados segurados e 1.916.187 acidentes registrados. Daí até 1994, pelos dados do INSS, observa-se uma diminuição significativa na ocorrência de infortúnios do trabalho e, de 1994 até 1997, houve uma oscilação, mas o 
patamar de acidentes registrados foi mantido, conforme se observa na Tabela 1 e Figura 2 e 3 (Ribeiro Filho, 1981; Midorikawa et al., 1996). Isto pode ser explicado pela subnotificação (fator que deve ser observado em qualquer levantamento de dados) e, também, como resultado das medidas de segurança exigidas pela Legislação Brasileira.

Entretanto, esses dados foram contestados pelos sindicatos, pois nem todo acidente do trabalho é notificado - já que os acidentes registrados normalmente são aqueles que implicam afastamento do trabalho -, e que os empregados informais não constam da estatística oficial, o que vem confirmar as observações feitas por Molinié \& Volkoff (1985) que relatam que, na França, as estatísticas também tinham distorções em decorrência da subnotificação.

Apesar da melhora das estatísticas de acidentes de trabalho, o modelo de Saúde Ocupacional não foi suficiente para atender aos objetivos propostos porque, de acordo com Mendes \& Dias (1991), mantém o referencial da medicina do trabalho firmado no mecanicismo. Este modelo não concretiza o apelo à interdisciplinaridade pois as atividades apenas se justapõem, desarticuladas e sem integração. A capacitação de recursos humanos, a produção de conhecimentos e de tecnologias de intervenção não acompanham a velocidade das transformações dos processos de trabalho e a manutenção da saúde ocupacional no âmbito do trabalho, em detrimento do setor saúde. 
Tabela 1 - Índices de acidentes de trabalho ocorridos entre 1970 e 1997.

\begin{tabular}{|c|c|c|c|}
\hline ANOS & $\begin{array}{l}\text { EMPREGADOS } \\
\text { SEGURADOS }\end{array}$ & $\begin{array}{c}\text { ACIDENTES } \\
\text { REGISTRADOS }\end{array}$ & $\begin{array}{c}\text { ACIDENTES } \\
\text { EMPREGADOS (\%) }\end{array}$ \\
\hline 1970 & 7.234 .022 & 1.220 .111 & 16,75 \\
\hline 1971 & 7.553 .472 & 1.330 .523 & 17,61 \\
\hline 1972 & 8.148 .987 & 1.504 .723 & 18,47 \\
\hline 1973 & 10.956 .956 & 1.632 .696 & 14,90 \\
\hline 1974 & 11.537 .024 & 1.796 .761 & 15,57 \\
\hline 1975 & 12.996 .796 & 1.916 .187 & 14,74 \\
\hline 1976 & 14.945 .489 & 1.743 .825 & 11,67 \\
\hline 1977 & 16.589 .605 & 1.614 .750 & 9,73 \\
\hline 1978 & 16.638 .799 & 1.551 .501 & 9,32 \\
\hline 1979 & 17.637 .127 & 1.444 .627 & 8,19 \\
\hline 1980 & 18.686 .355 & 1.464 .211 & 7,84 \\
\hline 1981 & 19.188 .536 & 1.270 .465 & 6,62 \\
\hline 1982 & 19.476 .362 & 1.178 .472 & 6,05 \\
\hline 1983 & 19.671 .128 & 1.003 .115 & 5,10 \\
\hline 1984 & 19.637 .915 & 961.575 & 4,89 \\
\hline 1985 & 20.106 .390 & 1.077 .861 & 5,36 \\
\hline 1986 & 21.568 .660 & 1.207 .859 & 5,60 \\
\hline 1987 & 22.320 .750 & 1.137 .124 & 5,09 \\
\hline 1988 & 23.045 .901 & 992.737 & 4,31 \\
\hline 1989 & 23.678 .607 & 888.343 & 3,75 \\
\hline 1990 & 22.755 .875 & 693.572 & 3,05 \\
\hline 1991 & 22.792 .858 & 629.918 & 2,76 \\
\hline 1992 & 22.803 .065 & 532.514 & 2,33 \\
\hline 1993 & 22.722 .008 & 412.293 & 1,81 \\
\hline 1994 & 23.016 .637 & 388.304 & 1,68 \\
\hline 1995 & 23.614 .200 & 424.137 & 1,79 \\
\hline 1996 & 24.311 .448 & 395.455 & 1,62 \\
\hline 1997 & 23.275 .605 & 421.343 & 1,81 \\
\hline
\end{tabular}

(Fonte: Revista CIPA v.20, n.238, 1999) 


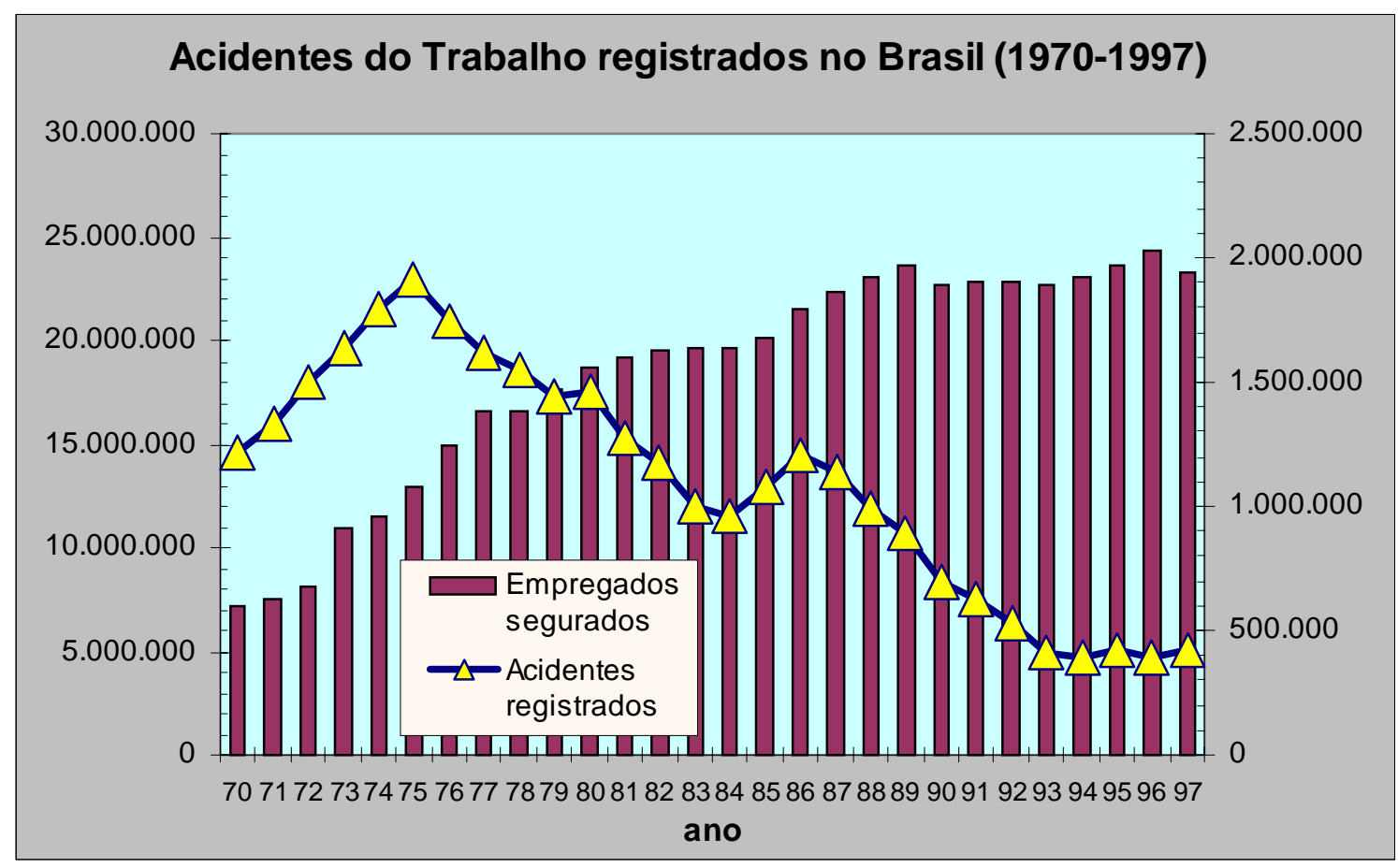

Fonte: INSS

Figura 2 - Freqüência de acidentes de trabalho registrados e empregados segurados no Brasil, de 1970 a 1997.

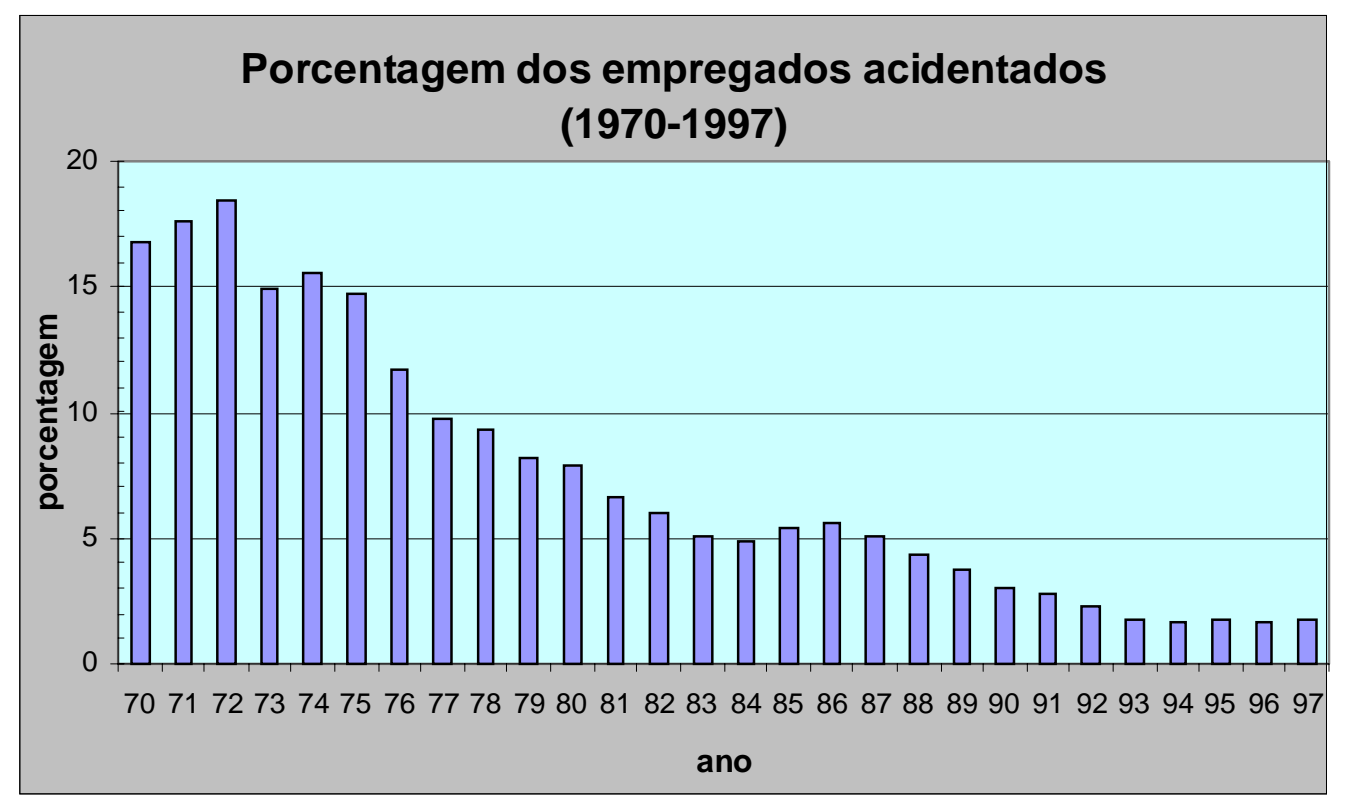

Fonte: INSS

Figura 3 - Percentuais de empregados acidentados no Brasil de 1970 a 1997. 
Alguns exemplos de questões que contribuem para a discussão das insuficiências existentes no âmbito da saúde ocupacional são a desconfiança dos trabalhadores com relação aos procedimentos técnicos e éticos da equipe de saúde ocupacional - como os exames pré-admissional e periódicos utilizados para práticas discriminatórias - e a queda do "Limite de Tolerância" - cuja fundamentação científica é questionada, pois não existe exposição segura (Mendes \& Dias, 1991).

A partir daí teve início, nestes últimos vinte anos, uma intensa mudança do processo social no âmbito das relações entre trabalho e saúde, que delinearam a saúde do trabalhador.

O objeto da saúde do trabalhador pode ser definido como o processo saúde e doença dos grupos humanos em relação ao trabalho. A saúde do trabalhador busca a explicação sobre o adoecer e o morrer dos trabalhadores, por meio do estudo dos processos de trabalho, de forma articulada com o conjunto de valores, crenças e idéias, as representações sociais e a possibilidade de consumo de bens e serviços, na "moderna" civilização urbano-industrial (Mendes \& Dias, 1991).

Para Mendes e Dias (1991), a saúde do trabalhador considera o trabalho enquanto organizador da vida social como o espaço de dominação e submissão do trabalhador pelo capital, mas igualmente da resistência e do fazer histórico, no qual os trabalhadores assumem o papel de sujeitos capazes de pensar e de se pensarem no conjunto das representações sociais. 
Em 1986, este processo social expressou-se nas discussões da VIII Conferência Nacional de Saúde e na I Conferência Nacional de Saúde dos Trabalhadores, influenciando a mudança de enfoque na Constituição Federal de 1988 e na Lei Orgânica da Saúde, com a denominação Saúde do Trabalhador (Mendes \& Dias, 1991).

Ambas falam do direito do cidadão à saúde e impõem ao Estado o dever de garantir esse direito, tanto mediante assistência médica e hospitalar e ações preventivas, quanto por políticas econômicas e sociais que condicionem e determinem o estado de saúde individual e coletivo da população.

Os artigos de números 196 a 200 da Constituição da República Federativa do Brasil de 1988 (Brasil, 1992) dizem respeito à saúde. Encontramos, no artigo 196, que a "saúde é direito de todos e dever do Estado, garantindo mediante políticas sociais e econômicas que visem à redução do risco da doença e de outros agravos e ao acesso universal e igualitário às ações e serviços para a sua promoção, proteção e recuperação". O artigo 200, inciso II diz que, ao sistema único de saúde compete executar ações de saúde do trabalhador, e o inciso VII preconiza "colaborar na proteção do meio ambiente, nele compreendido o do trabalho".

Outra lei importante é a de oํ 8080, de 19/09/90 - Lei Orgânica da Saúde (Brasil, 1990a) -, que dispõe sobre as condições para a promoção, proteção e recuperação da saúde. Ela dá as diretrizes das ações e serviços de saúde no território nacional, inclusive com relação à saúde do trabalhador. 
A Organização Mundial da Saúde, em 1960, definiu saúde como "um estado de completo bem-estar físico, mental e social e não apenas a ausência de enfermidade". Com essa definição, a OMS considerou a como um estado susceptível de gradações, apesar de ser difícil atingi-la. Entre o estado de saúde ideal - que seria o grau máximo de bem-estar físico, mental e social, e o grau máximo de desequilíbrio - que seria a incapacidade total, com vida meramente vegetativa -, existe uma gama imensa de estados intermediários. É impossível traçar a faixa de separação entre saúde e doença, pois indivíduos medicamente doentes comportam-se e agem muitas vezes como em plena saúde, enquanto outros, medicamente saudáveis, vivem vidas vazias e ineficientes (Chaves, 1986).

Dejours (1985) faz três comentários sobre saúde. No primeiro aborda a fisiologia, lembrando que não existem constantes biológicas no organismo, e sim variáveis em constante movimento e a saúde não é, portanto, um estado fixo, uniforme.

Com relação ao aspecto psicossomático, sabe-se que muitas doenças aparecem quando o trabalhador vive um momento difícil. Para o autor, a saúde mental não é a ausência de angústia nem o conforto constante, pois existem pessoas que, apesar das angústias, são sadias. A saúde se mantém quando os objetivos podem ser elaborados e há o desejo; caso contrário aparece a depressão, as defesas do organismo diminuem e o indivíduo pode ficar doente com maior facilidade. Para a psicopatologia do trabalho, a questão não é "Trabalho ou não trabalho?" , mas "Qual trabalho?" 
O autor também utiliza a distinção entre condições de trabalho e organização do trabalho, para discutir as repercussões do processo de trabalho sobre a saúde do trabalhador. As condições de trabalho compreendem as condições físicas, químicas e biológicas do ambiente de trabalho - temperatura, vibrações, poeiras, ruídos, por exemplo - e repercutem sobre as condições físicas do trabalhador. A organização do trabalho contempla a divisão técnica e social do trabalho - a hierarquia interna dos trabalhadores, o controle do ritmo e das pausas de trabalho pela empresa e o padrão de sociabilidade interna - e repercute sobre a saúde mental do trabalhador, causando sofrimento psíquico e doenças mentais e físicas.

Para Dejours (1985), a organização do trabalho - que é a divisão das tarefas e a divisão dos homens - possibilita a existência de organizações perigosas e de organizações não perigosas para o equilíbrio psíquico. As organizações não perigosas oferecem um campo de ação em que o trabalhador concretiza suas aspirações, idéias, imaginação e desejo. Isto é possível quando o trabalhador é escolhido livremente e a organização do trabalho é flexível para que ele possa administrá-lo de acordo com os desejos e as necessidades do seu corpo e as variações de seu estado de espírito. O bem-estar físico compreende a liberdade de regular as variações que surgem no organismo, e o bem-estar psíquico está vinculado à liberdade de auto-organização da vida e ao bem-estar social, à liberdade de ação individual e coletiva sobre a organização do trabalho. 
Com a Revolução Industrial, a fonte energética deixa de ser a força humana, pois as ferramentas artesanais foram substituídas pela máquina de impulsão mecânica. Se o gasto calórico agora é menor, surgem novos fatores de desgaste.

Surgem novos riscos físico-químicos, decorrentes das novas tecnologias e matérias-primas utilizadas na produção das técnicas taylorista, fayolista e fordista de gestão administrativa, e da intensificação do ritmo de trabalho - com o predomínio quase absoluto de movimentos estereotipados e repetitivos que, como conseqüência, provocam a fadiga física e mental dos trabalhadores. O trabalho por turnos rotativos tem implicações sobre o ciclo circadiano (transtornos gastrointestinais e sexuais, distúrbios do sono etc.) e sobre a vida social e familiar do trabalhador (Teiger, 1980; Dias, 2000).

O taylorismo, também conhecido como a organização científica do trabalho, através da divisão do trabalho influenciou também as diferentes disciplinas que consideram o trabalho apenas um campo de estudo e de experimentação de modelos parcelados do homem. Podem ser citados como exemplos estudos sobre o funcionamento do olho ou de um músculo, isolados do funcionamento do resto do corpo humano. Os resultados de tais estudos não devem ser aplicados ao trabalho, pois são apenas "objetos de observação" nos quais não se levou em consideração o que pensa o trabalhador, o seu grau de conhecimento sobre o trabalho, as suas motivações; assim, aplicar esses resultados à situação real de trabalho é muito questionável (Duraffourg, 1985). 
Duraffourg (1985) comenta que, sob o ponto de vista dos fatores de risco, a abordagem da relação saúde e trabalho leva, muitas vezes, a equipe de saúde a um dilema ético. Como exemplos podem ser citados os problemas detectados quando da seleção ou dos exames periódicos: o trabalhador deve ser mantido no trabalho, em uma situação perigosa, ou deve ser afastado, correndo o risco de perder o emprego? $\mathrm{O}$ autor sugere que, nessas circunstâncias, o trabalhador deve ser afastado do trabalho quando sua permanência nele comprometer a sua saúde de forma crescente.

Para Seligmann-Silva (1994),

"a ocultação do desgaste aos próprios olhos dos trabalhadores é uma permanente preocupação. É provável que exista sempre o temor - por parte dos detentores do poder econômico - de que, percebendo a extensão dos perigos e das agressões à saúde, ocorra o desestímulo da mão-de-obra ou, quiçá, sua evasão. Assim surge, para o capital, a necessidade de utilizar mecanismos capazes de abstrair os riscos".

Essa abstração dos reais perigos a que o trabalhador está exposto é expressa pelo processo no qual o dinheiro passa a presidir as relações sociais, mediante uma lógica que se torna modelo dominante para a vida mental, para as atitudes e para a produção das pessoas que trabalham na empresa (Seligmann-Silva,1994).

Para o trabalho, o que conta não é mais o que o trabalhador faz, o esforço por ele despendido e sua inventividade, mas os resultados financeiros que seu trabalho traz à empresa. No que concerne à saúde e à integridade física do trabalhador, essa análise pode ser entendida quando se considera a situação do trabalhador que é levado a aceitar que as condições 
de insalubridade, os riscos de vida (periculosidade) e a própria penosidade do trabalho sejam transformados em fator monetário, como adicional de insalubridade e de periculosidade, ao invés de levar a melhores condições de trabalho.

"Na situação brasileira, ainda um outro fator se acrescenta para esse êxito da dominação: os baixos salários, que fazem com que os adicionais de insalubridade, ou de periculosidade, e os ganhos por horas-extras sejam extremamente bem aceitos e desejados" (Seligmann-Silva, 1994).

A percepção do dano à saúde varia de indivíduo para indivíduo em função da idade, da história pessoal, da formação, dos antecedentes profissionais e da situação familiar e social de cada um, o que faz com que a relação trabalho e saúde tenha sentido apenas quando analisada individualmente (Duraffourg, 1985).

Não é mais possível discutir saúde sob o ponto de vista de sua degradação, pois essa ótica a reduz a um estado caracterizado pela ausência de doença ou de danos funcionais ao organismo. Deve-se, sim, enxergar a relação saúde e trabalho como uma soma de fatores de risco e de danos patológicos particulares, investigando como homens e mulheres dispõem de meios para manter a boa saúde no trabalho (Duraffourg, 1985).

As seleções por aptidões são inaceitáveis, e as condições de trabalho devem ser concebidas e organizadas em função dos trabalhadores. A organização da produção deve ser repensada a partir das exigências e do desenvolvimento de cada um (Duraffourg, 1985).

De acordo com Duraffourg (1985), a atividade do homem é um dos meios pelos quais ele pode construir a sua saúde, e a situação de trabalho é 
a ocasião em que ele desenvolve essa construção. Não se deve negligenciar ou ignorar os fatores de risco, e sim relacioná-los ao conjunto dos integrantes da situação de trabalho e de vida do trabalhador. Assim, o conhecimento da população trabalhadora e da atividade que esta desenvolve é condição fundamental para apreciar os perigos que as situações de trabalho podem trazer.

Qualquer abordagem especializada da relação saúde e trabalho é perigosa, e os conhecimentos devem ser reorganizados a partir da atividade dos trabalhadores, que desempenha papel fundamental nessa interface (Duraffourg, 1985).

Segundo Teiger \& Laville (1981) as condições de trabalho deixam, a curto, médio e longo prazos, traços (seqüelas) mais ou menos graves, como por exemplo as lesões das funções perceptivas, motoras e osteoarticulares, das funções mentais, da personalidade etc.

Teiger (1980) descreve os distúrbios vertebrais e osteoarticulares provocados por posturas forçadas relacionadas às restrições de tempo, por exemplo, nos trabalhadores de linhas de montagem; as modificações do sono e do ritmo alimentar acarretadas pelo trabalho em turnos ou noturno; os problemas oftalmológicos que acometem aqueles que trabalham com leitura de microfichas e controle de garrafas; a fadiga auditiva prolongada nos rotativistas etc.

O autor também a persistência de condutas condicionadas pelas exigências da tarefa (condutas estereotipadas): as telefonistas, em situações de refeições ou no cabeleireiro, falam frases-padrão comuns em seus 
diálogos; esses lapsos provocam um sentimento de perda do controle de si próprias. Quanto aos aspectos temporais da vida quotidiana, o mais estudado é a preocupação constante com o tempo de execução do trabalho, que se manifesta na vida fora do trabalho. No caso das telefonistas, a pressão para passar rapidamente as informações no dia-a-dia faz com que, fora do trabalho, tenham a constante preocupação de se desembaraçar daquilo que deve ser feito. Os efeitos gerais da atividade laboral sobre a organização do tempo extra-profissional ocorre nas telefonistas e nos trabalhadores de linhas de montagem de aparelhos eletrodomésticos - cuja necessidade de se recuperar do cansaço é muito grande - que, com o propósito de reservar o máximo de tempo para o descanso, não permitem qualquer mudança nos hábitos horários de refeição e/ou de repouso, o que atinge gravemente sua vida social e familiar. Outros problemas que atingem o estado geral e a personalidade, a longo prazo, tais como os distúrbios de sono e digestivos, os distúrbios do humor e do caráter, também são relatados na literatura.

Para Fisher \& Paraguay (1989), os efeitos do trabalho em turnos sobre a saúde são bastante conhecidos. As diversas formas de organização do trabalho, que podem contemplar jornadas noturnas ou em turnos - com horários irregulares de entrada e de saída do serviço, e a necessidade de trabalhar em finais de semana e em feriados, a ausência de convivência sociofamiliar nos períodos em que normalmente filhos, esposa e amigos se encontram - provocam profundas marcas nestes trabalhadores ao longo dos anos. 
As alterações podem se manifestar, nesses trabalhadores, a curto, médio e longo prazos, e podem ser observadas durante o período produtivo de trabalho ou após a aposentadoria. Além disto, o trabalho em turnos pode interferir em diferentes esferas da vida social: no desempenho profissional, na manifestação de problemas, em doenças cardiovasculares, em doenças de origem nervosa, em deficiências imunológicas e na vida sociofamiliar (Fisher \& Paraguay, 1989).

A manifestação subclínica das perturbações causadas principalmente pelo trabalho em turnos e noturno é claramente observável na análise dos ritmos biológicos - denominada cronobiologia -, que é "o estudo sistemático da organização temporal da matéria viva, em todos os níveis de organização” (Cipolla-Neto et al., 1988; Marques \& Menna-Barreto, 1997). Como exemplo de uma das desordens temporais facilmente detectáveis, tem-se o ritmo circadiano da temperatura. A variação diária da temperatura sofre consideráveis desvios de sua normalidade durante os períodos de vigia e de sono. A dessincronização interna entre o ritmo da temperatura e o ciclo vigília-sono tem como conseqüência o desencadeamento e/ou o agravamento dos distúrbios de sono.

A análise das seqüelas deve levar em conta o espaço em que se manifestam estas marcas, o local de trabalho, o local da vida fora do trabalho, o tempo de aparição e sua repercussão social. No plano coletivo, as seqüelas das condições de trabalho sobre a saúde de cada trabalhador modelam as características da mão-de-obra e refletem-se no emprego e na 
desigualdade social, em termos de enfermidades e de esperança de vida (Teiger, 1980).

Wisner (1987) e Fialho \& Santos (1997) lembram que os Indicadores Indiretos de Condições de Trabalho procuram analisar a população trabalhadora, pois o que determina a pirâmide de idade em determinado trabalho são as condições em que ele se dá, o tempo de serviço, a predominância de determinado sexo, a qualificação ou nível de instrução, os dados globais por setor de administração e a produção. Com estes dados tem-se uma boa visão das condições do trabalho. Se no local de trabalho existe a predominância de um dos sexos ou de uma determinada faixa etária, isso indica que alguma coisa não permite que outras classes ali trabalhem, caracterizando a inadequação do posto de trabalho. A análise das verbalizações (morbidade referida ou sentida) do trabalhador também é importante, pois ele tem uma visão particular sobre a sua tarefa, sobre as condições do ambiente e sobre as dificuldades que cercam sua atuação; além disso, é necessário conhecer, em parte, os efeitos das condições em que ele vive. Tais informações devem ser confrontadas com os dados obtidos na pesquisa sobre o local de trabalho e com a análise dos prontuários médicos, para permitir uma visão mais global e real da situação de trabalho.

A saúde do trabalhador é uma área ainda em processo de construção, tanto por profissionais da saúde de várias formações, como por trabalhadores que buscam viver com saúde (Mendes \& Dias, 1991). 
Dias (2000) descreve as principais características da atenção à saúde dos trabalhadores como sendo:

- "Integralidade das práticas, ou indissociabilidade das ações preventivas e curativas;

- Necessidade de uma atuação transdisciplinar e interinstitucional;

- Complexidade e dinamismo decorrentes das mudanças nos processos produtivos; $e$

- Participação dos trabalhadores enquanto sujeitos das ações de saúde".

A integralidade na abordagem do processo saúde-doença deve atingir desde o trabalhador individual até o coletivo da empresa, passando para a comunidade, consumidores etc. As ações voltadas à saúde do trabalhador devem englobar atos ligados à promoção, à proteção e à reabilitação da saúde, de forma integrada e sempre conjuntamente ao resgate do saber do trabalhador sobre as relações saúde-doença-trabalho, o que fará com que ele passe de objeto a sujeito desse processo (Dias, 2000).

A inter e a transdisciplinaridade são importantes por causa das imprevisíveis conseqüências que a complexidade das relações de trabalho terceirização, mercado informal -, o dinamismo dos processos produtivos com novos produtos, tecnologias, materiais e a organização do trabalho trazem à saúde dos trabalhadores (Dias, 2000).

A abordagem interdisciplinar e interinstituicional é uma necessidade que decorre de questões teóricas e práticas, como a definição do objeto da pesquisa - já que a mesma palavra tem significados diferentes para cada disciplina -, a harmonização dos pontos de vista, a interpretação dos resultados e a complementação pelos diferentes conhecimentos específicos 
de forma a que, juntos e trabalhando integrados, os profissionais atinjam o objetivo de manter a saúde do trabalhador em um estado ótimo.

\subsection{DA ODONTOLOGIA NO AMBIENTE DE TRABALHO ATÉ A ODONTOLOGIA SOB A ÓTICA DA SAÚDE DO TRABALHADOR}

Por não haver uma área estabelecida, a bibliografia referente à relação odontologia-trabalho é bastante grande e encontra-se dispersa.

O trabalho mais antigo que aborda esse assunto é de Ramazzini que, em 1700, no seu livro De Morbis Artificum Diatriba, já relatava sinais odontológicos de doenças profissionais.

No Capítulo I - Das Doenças dos Mineiros - o autor escreve:

"As doenças que atacam os cavouqueiros, assim como os artífices do mesmo gênero, são principalmente: dispnéia, tísica, apoplexia, coquexia, paralisia, tumores nos pés, perda de dentes, úlceras nas gengivas, dores articulares e tremores." (1992, grifos nossos)

No mesmo capítulo, Ramazzini conta que Tozzi, na parte II do seu livro "Prática" - capítulo "da asma" -, relata que as pessoas que derretiam prata estavam sujeitas à perda dos dentes, e viravam a espádua contra a direção dos ventos para tentar evitar a fumaça.

No Capítulo II - Das Doenças dos Douradores -, Ramazzini (1700) comenta:

"ninguém desconhece o lamentável dano que o mercúrio causa aos ourives, ocupados, geralmente, em dourar o mercúrio no fogo, não podendo os operários virar o rosto para evitarem a absorção dos 
vapores venenosos ... Tremem o pescoço e as mãos, perdem a dentadura, bambeiam suas pernas...” .

"Coube-me examinar, ultimamente, a um jovem dourador que, depois de dois meses deitado, morreu; por não ter cuidado com as emanações do mercúrio, ... apareceram, também, úlceras dolorosas na boca, das quais corria continuamente abundante $e$ escuro sangue." (1992)

No capítulo III, o autor aborda as doenças dos iatraliptas massagistas -, que friccionavam mercúrio no corpo dos portadores de sífilis. Embora usassem luvas, estas não os protegiam, pois o mercúrio passava pelo couro - que, em outros casos, era usado para filtrar e purificar o mercúrio -; além disso, durante o trabalho - realizado próximo a uma chama de fogo - inalavam esse metal pela boca e pelo nariz. Hildano (apud Ramazzini, 1700) relata o caso de uma mulher que, quando passava mercúrio no marido sentada no leito, impregnou o ar com o metal que, penetrando pela boca, provocou-lhe muita salivação e ulceração na garganta.

Com relação às doenças dos vidraceiros, escreve o autor:

"Infortúnios muito piores sobreviverão durante a fabricação de vidros coloridos para braceletes e adereços para mulheres plebéias, ..., devem combinar o bórax calcinado com o antimônio e uma certa quantidade de ouro, moendo esses ingredientes até convertê-los em pó impalpável que se mistura ao vidro para obterse a pasta necessária à operação; enquanto executam esse trabalho (por mais que se tente cobrir o rosto ou afastá-lo) não deixam de absorver as malignas emanações; $e$, assim como os vemos cair exânimes ou sufocados, com o tempo aparecem úlceras na boca, estômago e na traquéia..." (1992).

Ao abordar as doenças dos pintores, o autor conta que estes vestiam, para trabalhar, blusas sujas e manchadas de tinta e, assim, absorviam "vapores malignos" pelo nariz e pela boca. Tais vapores 
penetravam pelas vias respiratórias e misturavam-se ao sangue, perturbando a "economia das funções naturais" e causando, dentre outras afecções, caquexia, tremores nos membros, enegrecimento dos dentes, palidez da face etc. (grifos nossos).

No Capítulo XLI - Das doenças dos Pedreiros -, temos

"os pedreiros estão sujeitos quase às mesmas doenças dos que trabalham a cal; porque quando extinguem a cal viva, jogando água sobre ela, para construir paredes ou para rebocá-las, é sempre a mesma cal que têm na mão, ..., não podendo evitar respirar pelo nariz e pela boca partículas tenuíssimas que se evolam e que irritam a boca, a garganta e os pulmões, levando a um mau estado de saúde." (1992)

Na bibliografia consultada, constatamos a existência de trabalhos sobre manifestações bucais de doenças profissionais nos séculos XVIII e XIX. Entretanto, e considerando que citar essas obras tornaria este capítulo ainda mais extenso, optamos por mencionar, além de Ramazzini - dada a sua importância histórica - apenas os trabalhos publicados a partir de 1917.

Em 1917, Thomas escreveu sobre as causas das "piorréias alveolares". A parte II - denominada de Doenças Gerais com Localização na Boca -, descreve, dentre outras doenças, manifestações decorrentes de intoxicação por chumbo, fósforo, arsênico, sulfito de hidrogênio, nitrobenzeno, sais de cobre, bismuto e mercúrio.

Discutindo a importância do trabalhador na indústria, Thomas (1918) enfatiza que o ser humano é a máquina mais perfeita já criada, e postula que maior atenção deve ser dada a sua saúde. O reconhecimento - por parte do empregador e do empregado - da saúde no trabalho como um princípio para o desenvolvimento industrial levará à lealdade e à boa saúde e, 
conseqüentemente, resultará em um aumento da eficiência do empregado e da produtividade, possibilitando o aumento dos lucros da empresa. $\mathrm{O}$ autor ainda cita as empresas do Estado de llinois que, sabiamente, implantaram serviços odontológicos com pequeno custo anual.

Pettibone (1923) relata que havia, nos Estados Unidos da América (EUA), mais de 100 indústrias que ofereciam tratamento odontológico gratuito, 26 delas localizadas no Estado de Ohio. $\mathrm{O}$ autor preconiza que os consultórios odontológicos gratuitos de indústrias devem estar nos locais de trabalho, e declara: "os cinqüenta anos atrás foram gastos para aperfeiçoar o maquinário e os próximos cinqüenta anos devem ser gastos no aperfeiçoamento da máquina humana." (op.cit.)

Estudando as infecções dentais e as doenças degenerativas a elas relacionadas - em pacientes e em suas famílias -, Price (1925) concluiu que uma pessoa que tem normalmente alta defesa - expressa pela ausência de lesões reumáticas recorrentes -, ela luta contra as bactérias e toxinas vindas do ápice do dente envolvido, vedando a fonte da infecção. Entretanto, quando tem uma gripe, está em gestação ou em estado de nutrição deficiente, torna-se incapaz de manter essa luta; assim, as bactérias e toxinas passam para o corpo e levam a infecção a vários órgãos e tecidos. Para o autor, apesar da importância dessas constatações, um grande programa de pesquisa sobre o assunto deveria ser implementado.

Baum (1934) abordou as afecções e infecções da boca que atingem os dentes, a maxila, a mandíbula, as partes moles da boca e as estruturas adjacentes, enfatizando a importância da odontologia industrial. $\mathrm{O}$ autor 
comenta que, nos cinqüenta anos de desenvolvimento industrial anteriores ao seu estudo, essa área despertou pouco interesse, e que a própria ciência odontológica a negligenciara. Descreve as manifestações bucais por alguns agentes químicos como o chumbo, o mercúrio, o fósforo, os ácidos etc. Relata também a freqüência de cáries e de doenças da cavidade bucal e dos tecidos adjacentes decorrentes de condições de traumas, temperatura, poeira, infecções e intoxicação em diferentes categorias profissionais. E exemplifica com a pneumatocele da glândula parótida em sopradores de vidro e músicos que usam instrumentos de sopro.

Em trabalho sobre a história da odontologia, Legge (1937) enfatiza que o cirurgião-dentista industrial rapidamente encontrou a sua importância nos programas de saúde de empresas de várias áreas. E avalia o padrão de eficiência desses serviços pela eliminação de focos de infecção dental, exames odontológicos, manutenção da higiene, realização de extrações e de restaurações, supervisão odontológica dos trabalhadores quanto aos materiais químicos empregados nas indústrias e cuidados voltados a fraturas de mandíbula e/ou maxila decorrentes de acidentes do trabalho.

Thomas (1940) discute a possibilidade de que as doenças bucais sejam a origem de infecções em outras partes do corpo. O autor preconiza o exame acurado, com cuidadosa análise das tomadas radiográficas, considerando que os abscessos dentários são uma ameaça, não somente por causa da possibilidade de transferência da infecção e de toxinas para outras partes do corpo, mas também porque causam uma diminuição da 
resistência do organismo. E ressalta a responsabilidade do cirurgião-dentista sobre a saúde do paciente quando realiza o exame bucal .

Em 1940 Austin realizou, com médicos da Clínica Mayo, entrevistas de opinião sobre a relação entre infecção dental e doenças sistêmicas. $O$ autor comenta que alguns profissionais que seguiam a teoria da infecção focal tinham resultados desapontadores para eles próprios e para seus pacientes. Foram ouvidos gastroenterologistas, cardiologistas, hematologistas, oftalmologistas, reumatologistas, dermatologistas e bacteriologistas; os resultados apontaram que não nem sempre os médicos estabelecem essa relação, apesar de avanços nesse sentido. Assim, o cirurgião-dentista deve informar o paciente, que envidará os esforços necessários para melhorar o seu bem-estar.

A relação entre problemas dentais e problemas gastrointestinais e oftalmológicos que diminuem a capacidade laborativa é ressaltada por Miller (1941). Assim, o autor postula a inserção da odontologia nas indústrias, e relata a sua experiência de dez anos organizando serviços odontológicos em empresas com baixo custo - cerca de $50 \%$ dos custo de um consultório particular - e qualidade satisfatória. E enfatiza a importante ação de exames periódicos realizados a cada 6 ou 12 meses para a prevenção de doenças bucais.

Analisando a prevalência e as características de serviços dentais em indústrias, Dunning et al. (1941) enviaram questionários a 1469 empresas, das quais $869(59 \%)$ responderam; destas, $163(18,8 \%)$ mantinham tais serviços. Os autores constataram que os cirurgiões-dentistas controlavam os 
padrões profissionais nos serviços odontológicos, mas que a responsabilidade executiva estava nas mãos dos médicos ou do diretor de pessoal. Também observaram que a maioria das empresas permitia que o empregado se tratasse sem deduzir do salário o tempo gasto com 0 tratamento. O exame, a profilaxia e uma pequena gama de tratamentos eram realizados às custas da empresa e que, algumas vezes, parte desse custo era repassada aos empregados. Além disso, lembram a necessidade de cuidados voltados a injúrias dentais de origem ocupacional e enfatizam que é desejável a adoção dos padrões para serviços odontológicos em indústrias da American Dental Association (ADA).

Dória (1941), em tese para a cátedra de Higiene e Odontologia Legal da Faculdade Nacional de Odontologia da Universidade do Brasil intitulada Infortunística e Odontologia, abordou os acidentes de trabalho, as doenças profissionais e seu aspecto pericial. Com relação aos acidentes de trabalho, abordou as lesões dos lábios, da região geniana, do mento, das glândulas salivares, da língua, do soalho da boca, da região palatina, dos dentes e dos maxilares. No que concerne às doenças profissionais, relatou as intoxicações que mais freqüentemente podem levar a processos patológicos do complexo estomatológico, como aquelas decorrentes de chumbo, mercúrio, bismuto, níquel, cobre, arsênico, fósforo, manganês, zinco, cádmio, prata, antimônio, estanho, cromo, sulfureto de carbono, hidrogênio sulfurado, óxido de carbono e benzol. E, no último capítulo da tese, dedicouse a analisar o aspecto pericial dessas intercorrências. 
Para Goldhorn (1942), o aumento da proteção da vida contra os acidentes industriais, a prevenção e a eliminação de doenças ocupacionais têm como objetivo o aumento da eficiência industrial, a diminuição da perda de tempo por incapacidade parcial por acidente ou doença - que contribui para a produção de erros - e a redução de práticas desatentas que podem provocar acidentes de trabalho. O autor comenta a prevalência de doenças bucais e seus efeitos sobre a saúde geral, divide as infecções dentais em dois grupos - aquelas resultantes do avanço da cárie dentária e aquelas desenvolvidas nos tecidos gengivais - e sua influência na eclosão de reumatismos, problemas gástricos, halitose, problemas cardíacos, problemas do trato geniturinário, enfatizando que a implantação de serviços odontológicos na indústria deve ser considerada uma forma de reduzir as doenças nesse segmento somente pela prevenção e eliminação da infecção dental.

Em fevereiro de 1942, o Comitê de Economia da ADA publicou a proposta "Mínimo Padrão para Serviço Odontológico na Indústria" que, em sua essência, traz-nos: a indústria deve organizar seu serviço odontológico com adequadas facilidades para assegurar eficientes cuidados ao empregado que necessite de tratamento odontológico paliativo emergencial por causa de injúria ocupacional, ou que tenha desenvolvido manifestação bucal de doenças ocupacionais; todos os empregados devem ter acesso ao tratamento odontológico, e o serviço deve dedicar parte do tempo à educação dos trabalhadores sobre o valor da manutenção da saúde bucal; todos os empregados que entrarem na empresa devem ser submetidos a 
exames odontológicos; o sistema de fichas deve ser completo e acurado; as fichas devem ser preenchidas de forma acessível ao empregado, aos serviços médico e odontológico e às agências governamentais possibilitando a realização de análises estatísticas e comparações; os membros do serviço devem ser qualificados nas áreas que este compreende; o departamento de serviço odontológico deve ter completa responsabilidade sobre seu pessoal e sobre a qualidade dos serviços realizados; os cirurgiões-dentistas devem estar familiarizados com os processos industriais e atentos aos sinais de doenças bucais provocadas por agentes ambientais e devem comunicar os departamentos médico e de engenharia para que estudem e ajam contra o agente; o serviço deve se limitar a radiografias e profilaxia, e outras atividades devem ter a aprovação da sociedade dental do estado (American Dental Association, 1942).

Walls \& Bethlehem (1942) realizaram uma pesquisa com 841 empresas: 498 (59\%) delas responderam, das quais $116(13,8 \%)$ tinham serviço odontológico. Nenhuma empresa com menos de 100 empregados mantinha esse tipo de serviço. Os autores chegaram a conclusões semelhantes àquelas de Dunning et al. (1941) com relação à responsabilidade executiva dos médicos ou dos diretores de pessoal, e à não dedução salarial das horas em que o empregado se ausentou do trabalho para tratamento. Todas as empresas estavam satisfeitas com seu plano, e qualquer recomendação que fizessem seria baseada no próprio serviço. Finalizando, reforçam a importância do exame bucal semestral, com radiografias; preconiza que a profilaxia deve ser realizada pelo dentista ou 
pela higienista; o cirurgião-dentista particular deve ser notificado quando da necessidade de tratamento curativo; o empregado deve ser educado para valorizar a manutenção da saúde bucal. Quando os empregados sofrem injúrias nos dentes ou no tecido de suporte, e no caso de terem desenvolvido manifestações bucais decorrentes de doenças profissionais, devem ser examinados pelo cirurgião-dentista e encaminhados ao hospital ou ao cirurgião-dentista particular.

Em trabalho realizado em 1942, Hooper discorre sobre o absenteísmo nas indústrias americanas, e conclui que 25\% do absenteísmo de origem não-ocupacional está diretamente ligado às condições bucais. Reforça a relação entre infecções orais e doenças sistêmicas, citando trabalhos realizados pelo Serviço de Saúde Pública dos EUA e pela Companhia Metropolitana de Seguro de Vida. Discute a importância da profilaxia como forma de prevenção, e postula que a preocupação com o serviço odontológico na indústria deve caber ao executivo da empresa, ao médico industrial, ao cirurgião-dentista privado e ao próprio trabalhador.

Dunning (1942) descreveu as etapas de um plano de inicialização de serviços dentais industriais para empresas com 1000 ou mais empregados com base no padrão da ADA, esperando que o serviço odontológico industrial na época da guerra - que duraria alguns anos - resultasse em um programa permanente mesmo em tempo de paz.

Analisando as diferentes manifestações bucais de doenças ocupacionais, Schour \& Sarnat (1942) estudaram a estrutura afetada, o processo patológico, o agente etiológico e a ocupação. O maior mérito desse 
trabalho reside na sistematização de tabelas das manifestações bucais de doenças profissionais. Os autores concluem que a cavidade bucal é a porta de entrada dos agentes ocupacionais nocivos, e que os exames médicos realizados em trabalhadores industriais deveriam contemplar também exames odontológicos, pois estes têm algumas vantagens: o acesso à cavidade bucal é facil; o esmalte, a dentina e os tecidos moles podem revelar exposições ocupacionais passadas; efeitos sistêmicos podem ser transmitidos pela cavidade bucal através do sangue e da saliva, apresentando sintomas característicos. A má higiene torna o trabalhador mais susceptível aos problemas ocupacionais bucais; a prevenção, o diagnóstico precoce e o tratamento das doenças ocupacionais que apresentam manifestações bucais devem contribuir para a melhora das condições de trabalho, e para o estabelecimento e a manutenção de ótima condição de saúde geral e bucal.

Em 1943, Heacock discorreu sobre a organização de serviços odontológicos em indústrias de guerra. Nesse trabalho, o autor lembra que tais indústrias tinham que produzir material de guerra rapidamente e, conseqüentemente, tinham que eliminar todas as causas de doenças que provocassem ineficiência e perda de tempo de trabalho, como os problemas odontológicos. Descreve os fatores a analisar no planejamento de um programa de serviço odontológico que compreenda empresas grandes e pequenas - com menos de 500 empregados.

Avaliando a relação doença bucal-absenteísmo, Hooper (1943) a confirma as conclusões de outros pesquisadores, que constataram 
problemas decorrentes desse tipo de infecção em outros órgãos do corpo humano, como reumatismo, doença cardíaca e úlcera no estômago. O autor enfatiza a necessidade do exame radiográfico - pois observou que poucos departamentos médicos industriais incluíam exames de raios- $x$ rotineiramente - e do exame bucal como forma de prevenção barata, fácil e efetiva para o combate aos problemas decorrentes do ambiente ocupacional.

Goldhorn (1943) ressalta que um programa odontológico industrial deve fazer parte dos esforços integrados voltados à saúde dos trabalhadores, com o objetivo de "guardar o homem no trabalho" para aumentar sua eficiência do trabalhador e a segurança industrial, reduzindo o absenteísmo e a perda de tempo. E arrola, como funções desse programa odontológico, a realização de diagnósticos, a implementação de tratamentos para a erradicação de infecções dentais, o tratamento de lesões dentais dolorosas e agudas, o atendimento de problemas decorrentes de injúrias industriais, ações profiláticas de abrangência limitada, a higiene oral e a educação em saúde bucal.

Para Thomas (1943), as infecções bucais constituíam-se em séria ameaça para a produção das indústrias de guerra. $\mathrm{O}$ autor tomou como base trabalhos que mostravam a relação entre infecção bucal e doenças sistêmicas. Assim, postula que o serviço odontológico deve integrar os serviços de saúde industrial para prevenir doenças sistêmicas; diagnosticar doenças bucais em estágios iniciais; detectar manifestações bucais de doenças profissionais - comunicando a área médica para tratamento -; cuidar de todas as condições cirúrgicas traumáticas da boca; manter fichas 
cujo valor, em casos de desastres, têm um valor inestimável para a identificação; promover ações de educação em saúde aos trabalhadores, mostrando a importância da prevenção das doenças bucais.

A importância de iniciativas - por parte dos profissionais da odontologia - que atendam às demandas de uma reorganizada sociedade, assumindo a responsabilidade de implementar e dirigir programas de odontologia industrial foi ressaltada por Petty em 1943. O autor define a odontologia industrial como:

"serviço dental administrada por dentista ou dentistas em uma clínica ou hospital odontológico com salário ou com tarifas fixadas a serem pagas pelo empregador; pela contribuição voluntária ou involuntária, do empregado ou por algum plano de seguro".

Heacock (1943) relata que o primeiro serviço odontológico implantado na indústria americana data de 1915, e que em 1923 havia mais de 100 serviços odontológicos nas indústrias dos EUA. Considerando que as faltas ao trabalho por problemas odontológicos têm um volume significativo, cabe ao cirurgião-dentista coordenar o trabalho de forma a somar seus conhecimentos às funções do programa de higiene industrial, limitando os procedimentosao tamanho da empresa, a fim de proteger a saúde do trabalhador no local em atua profissionalmente com um mínimo de perda de tempo de serviço provocado pela doença bucal.

Em 1943, o Departamento de Odontologia em Saúde Pública e o Departamento de Higiene Industrial dos EUA sugeriram princípios para os programas odontológicos em indústrias. Esse documento explicitava as funções e os serviços que poderiam ser oferecidos, a forma de custeio e os equipamentos necessários, além de preconizar a integração entre esse 
serviço e o departamento médico e a manutenção adequada das fichas que deveriam estar sempre atualizadas. Com relação à oferta de serviços, postula que a qualidade é mais importante que a quantidade (Bureau of Public Health Dentistry \& Bureau of Industrial Hygiene, 1943).

Discorrendo sobre a necessidade de adoção de medidas profiláticas voltadas aos trabalhadores cujas atividades incluam o contato com fósforo, Baron (1944) ressalta três aspectos: a organização da clínica odontológica e de suas fichas, a seleção dos trabalhadores e a rotina de tratamento, destacando a importância cooperação dos trabalhadores - que devem ser instruídos a relatar qualquer dor ou anormalidade na região bucal.

Morrey (1944) ressalta que, em trabalhadores de indústrias de guerra, as dores de dentes e as infecções dentais contribuem com o inimigo porque diminuem a produção de materiais essenciais - diminuindo a eficiência e aumentando o erro e o risco de acidentes. A eliminação de infecções dentais, a melhora da higiene bucal e a manutenção de boas condições bucais ajudam na digestão e assimilação de nutrientes dos alimentos, melhorando a saúde e prevenindo doenças.

Em estudo realizado em 1944, Thomas discute a alta incidência de infecções bucais, os acidentes e as doenças que originam perda de tempo no trabalho, e a ameaça que as infecções bucais representam, pois podem provocar doenças em outros órgãos do corpo humano. E cita, como funções do programa de saúde bucal na indústria: o diagnóstico e a eliminação de infecções bucais; a educação em saúde para os empregados; a prevenção e o diagnóstico de manifestações bucais de doenças profissionais; o 
tratamento de traumatismos da boca e dos dentes; o tratamento de emergências agudas e de dores na região bucal; e o encaminhamento do empregado a especialistas, quando necessário.

Dunning \& Klein (1944) realizaram um trabalho na Companhia de Seguro de Vida Metropolitana dos EUA, cujo serviço odontológico foi implantado em 1915 - constituindo-se, assim, em um dos mais antigos serviços odontológicos industriais daquele país. O mencionado serviço foi compreendia procedimentos preventivos, e o índice de Dentes Cariados, Perdidos e Obturados (CPOD) em 1942 foi um pouco mais alto que em comparação com ela mesma em 1927. Teve uma menor razão de fatalidade (mortalidade) de dente, que é a razão de dente perdido e o índice CPOD, indicando o sucesso do programa de tratamento odontológico.

Kulstad (1945) relata que, em sua criação, o comitê industrial da ADA era composto por quatro cirurgiões-dentistas com conhecimento e interesse em odontologia industrial, e um consultor Secretário do Conselho de Saúde Industrial da Associação Médica Americana (AMA). Observou grande incidência de absenteísmo, de origem ocupacional e nãoocupacional, era complicada e agravada pelas doenças bucais. Assim, e considerando que algumas indústrias de guerra conseguiram uma boa relação entre os programas de saúde bucal e saúde geral - o que provocou queda nos índices de absenteísmo -, o autor preconiza que o termo saúde industrial só pode ser utilizado quando a empresa incluir, em seu programa, a odontologia industrial. 
A odontologia é fundamental para diminuir o absenteísmo no trabalho pois, embora a dor de dentes não necessariamente provoque faltas, causa desconforto e ineficiência.Desta forma, Dunning (1945) cita a Companhia de Seguro de Vida Metropolitana dos EUA, que em 1945 já prestava assistência odontológica há mais de vinte e cinco anos, apresentando bons resultados a um custo de 6 dólares/empregado/ com prevenção e cuidados sistemáticos.

Para Misher (1946), o serviço odontológico economiza dinheiro para a empresa. O pronto alívio da dor do empregado economiza o tempo que este gastaria visitando o cirurgião-dentista particular. Além disso, tal serviço promove a eliminação dos focos de infecção da boca, o reconhecimento das condições bucais que apontam para doenças industriais, além de propiciar o bem-estar do trabalhador e educá-lo quanto à importância da manutenção da saúde bucal. O autor também aborda operacionalização do serviço odontológico - funções e planejamento -, e a importância da cooperação e do respeito entre o cirurgião-dentista e o médico.

Em trabalho realizado em 1946, Heacock estudou as formas de lesões na cavidade bucal, como a abrasão, a cárie, a pigmentação do esmalte, a inflamação dos tecidos bucais, os distúrbios circulatórios e as degenerações dos tecidos duros e moles da cavidade oral.; O autor também discorre sobre as funções do serviço dental na indústria, e lembra que, para a ADA, a Odontologia Industrial, como a especialidade da prática dental e uma parte do programa de saúde industrial, está preocupada com a saúde dental do 
trabalhador, como ele afeta ou é afetado pelo seu trabalho e seu ambiente de trabalho.

Para Sappington (1946), é questionável a afirmação de que infecções bucais sejam a causa mais comum de doenças sistêmicas subagudas e crônicas, pois infecções dentais são comuns e as pessoas não são afetadas igualmente. Assim, propõe a realização de estudos conjuntos entre médicos e cirurgiões-dentistas para demonstrar essa correlação.

Em uma sessão da Associação Americana de Cirurgiões-Dentistas Industriais, Aston (1946) revisou as recomendações da Seção Odontológica da Divisão de Higiene Industrial do Departamento de Saúde para Programas Industriais Odontológicos da Sociedade Odontológica do Estado da Pensilvânia, o padrão mínimo adotado pela ADA e as recomendações para Programas Industriais da Casa de Delegados da Sociedade Odontológica do Estado da Pensilvânia em maio de 1944, mostrando os resultados da pesquisa sobre os serviços nas industrias.

Estudando o absenteísmo decorrente de problemas dentários e gengivais em indústrias do Tennessee, Puffer \& Sebelius (1946) constataram ausências de um dia ou mais da ordem de 47,3 por 1000 empregados, com uma razão de 0,210 dias por empregado. Os autores compararam essa razão àquela apontada em estudo realizado em indústrias do norte do Alabama, observando relativa superioridade do Tennessee. Assim, propuseram que os colegas coletassem e analisassem dados desse tipo para estabelecer sólidos programas de saúde dental industrial. 
Em 1946, o editorial da revista Journal of the American Dental Association (JADA) comentava que o absenteísmo em geral tinha aumentado durante a II Guerra Mundial, justamente quando os trabalhadores eram mais necessários para a produção. Em contrapartida, os programas odontológicos industriais haviam crescido pouco em relação aos programas médicos, apesar da iniciativa de vários órgãos. Esse editorial ainda ressaltava que a realização de estudos que demonstrassem a interação absenteísmo-doenças bucais promoveria o aumento do número de programas nessa área, e enfatizava a importância do trabalho de Puffer \& Sebelius de 1946 (American Dental Association, 1946).

Em 1947, Heacock publicou trabalho sobre a relação entre a odontologia e os serviços de saúde industrial. Nesse artigo, o autor frisa que o cirurgião-dentista deve conhecer os processos de fabricação usados na empresa e as leis de compensação do Estado; integrar o seu trabalho e achados com aqueles dos serviços médicos; realizar exames, tratamento emergencial, tratamento e eliminação de infecções orais, cirurgias bucais; ter conhecimentos de radiologia; dominar técnicas de educação individual e de grupo. Também deve organizar o serviço no que concerne aequipamentos, pessoal necessário e, adequação das fichas. E, quando houver necessidade de implementar serviços não oferecidos, deve encaminhar o trabalhador a outro profissional.

Goldhorn (1947) expõe a importância dos cuidados dentais em um programa de saúde industrial. A dor de dentes, a perda de sono, a fadiga e a distração mental são fatores que facilitam a ocorrência de acidentes de 
trabalho. As emergências dentais levam à perda de tempo e à interrupção do trabalho, mas com a colaboração entre o dentista e a equipe de saúde, é possível controlar as doenças profissionais que apresentam manifestações orais, levando o trabalhador a uma melhor condição de saúde a maior produtividade.

Com base em sua experiência de vinte anos na organização de serviços odontológicos em indústrias, Camp (1947) tece considerações interessantes sobre o planejamento desses serviços, como localização e tipo de sala clínica, equipamento necessário e serviços prestados.

Aston (1948) discute as relações da odontologia com a unidade de higiene industrial, com a sociedade odontológica local, com a indústria e com o trabalho, e conclui que o sucesso do programa de saúde dental industrial depende da interação e da cooperação entre todas as partes envolvidas.

Em 1948, Morvay escreveu sobre os procedimentos conservadores para evitar a perda dos elementos dentários, no tratamento de acidentes traumáticos. $\mathrm{O}$ autor comenta que alguns Estados permitem reclamações judiciais em tais casos. Também ressalta que o cirurgião-dentista, por meio dos exames periódicos realizados em cada empregado, pode promover a redução de problemas dentais decorrentes de métodos de produção, falta de segurança e equipamentos antiquados.

Em capítulo sobre lesões bucais e dentárias decorrentes de doenças profissionais, Dechaume (1949) descreve as manifestações bucais de doenças profissionais. 
Sappington (1949) postula que a inserção da odontologia em programas de higiene industrial justifica-se pela necessidade de evitar perdas de tempo e de dinheiro, para empregado e empregador, por doenças não-ocupacionais. O autor concorda com Schour \& Sarnat (1942), que concluíram que as condições de trabalho podem levar a manifestações bucais de doenças profissionais, e propõe uma minuciosa seqüência de exame bucal a ser adotada pelos cirurgiões-dentistas industriais.

Partindo do princípio de que toda medida que contribua para o bemestar físico geral do empregado não somente beneficiará a ele mesmo - pelo conforto e alegria na vida que proporcionará -, mas também beneficiará o empregador - pela diminuição do absenteísmo e aumento da eficiência do trabalho -, Gibson et al. (1950) realizaram um estudo no Departamento de Saúde da Merck. Foram examinados 132 funcionários - 70 operários e 62 executivos - pelo índice CPOD. Os resultados apontaram maior índice para os operários, tanto na faixa etária inferior a 40 anos quanto na faixa etária superior a 40 anos. Os autores concluíram que, como a amostra avaliada era pequena, não foi possível determinar o sucesso ou o insucesso do programa; entretanto, ficou-lhes a impressão de melhora da eficiência no trabalho e de diminuição do absenteísmo.

Em 1950, McCord abordou os chamados estigmas do trabalho em profissões como a de sapateiro, soprador de vidro, costureira e cornetista. Nesse sentido, destaca a halitose ocupacional, como os odores de tetracloreto de carbono, benzol etc., e as intoxicações por substâncias químicas como o fósforo, o benzol e o mercúrio. 
MacKenzie (1951) relata a importância das duas guerras mundiais no processo de implantação de serviços odontológicos na Companhia Ford que instituiu esse programa em 1916 - para atender às fábricas que tinham maior contingente de empregados. O autor lembra que os trabalhadores que atuavam na construção de bombas B-24 de uma das fábricas (Willow Run) dessa empresa apresentavam um problema dentário peculiare, qual seja, a prevalência de injúrias em dentes anteriores - decorrentes do ato de rebitar -, que foram resolvidas com a utilização de protetores de borracha bucais usados por lutadores de boxe. E ressalta a importância de haver uma relação harmônica entre o cirurgião-dentista industrial e o cirurgião-dentista particular.

Descrevendo o programa odontológico do Serviço de Cooperativa criado para facilitar a administração e as atividades filantrópicas de três empresas da Pensilvânia, Dougherty (1951) comenta que, em exames realizados em 1949 e em 1950, 45,1\% e 63,3\% dos trabalhadores, respectivamente, necessitavam de imediata atenção odontológica. O autor conclui que, embora esse programa tivesse sido instituído recentemente, e apesar de não ter sido possível demonstrar estatisticamente o seu sucesso, os empregados demonstraram satisfação com sua implantação.

Para verificar os efeitos dos compostos de chumbo e de ácidos nos dentes e nos tecidos orais, Aston (1952) realizou um estudo em cinco empresas fabricantes de baterias. Concluiu que havia concentrações de chumbo superiores à concentração máxima permitida em determinadas áreas dessas indústrias, o que provocava manifestações como deposição de 
chumbo na gengiva e na mucosa bucal, grandes depósitos desse metal nos dentes, gengivite e reabsorção do tecido alveolar, descoloração e dissolução do esmalte provocadas pelos ácidos.

Berman (1952) relatou a experiência da atividade odontológica do programa de um centro médico na Pensilvânia. Com uma população de três distritos industriais com aproximadamente 15.000 pessoas, e uma equipe composta por dois cirurgiões-dentistas, houve um aumento progressivo no número de pacientes atendidos e em retorno. Em 1948 - quando o serviço foi implantado - foram atendidos 1033 pacientes; em 1949 houve 1912 novos pacientes e 222 retornos; em 1950, 1704 novos pacientes procuraram o atendimento e 543 retornaram. Para o autor, esse crescimento demonstra aceitação do serviço pelas pessoas.

Para Dunning (1952), embora o absenteísmo decorrente de problemas odontológicos seja pequeno, ele é importante. Isto porque as pessoas acometidas por patologias dessa esfera necessitam continuar os tratamentos posteriormente, ou seja, os procedimentos não se limitam à resolução da fase aguda. As seqüelas de infecções dentais, geralmente, não são incluídas nas estatísticas, e podem ser prevenidas. Assim, o autor conclui que a implantação de um bom serviço dental preventivo - baseado na educação em saúde e no encaminhamento de trabalhos de restauração ao profissional particular -, que também atue em situações emergenciais como paliativo é recomendável em indústrias com mais de 1000 empregados. 
Em 1952, o Council on Dental Health - Conselho de Saúde Dental dos Estados Unidos pesquisou 162 empresas que possuíam serviço odontológico e obteve 52 respostas, que indicaram que somente 4 programas estavam em conformidade com o padrão recomendado pela ADA e que não há, geralmente, entendimento sobre o valor e o escopo de programas dessa natureza nas indústrias.

Para Morvay (1952), para estabelecer se houve injúria dental resultante de trauma industrial, é fundamental que as fichas dentais sejam mantidas adequadamente, e que sejam realizados exames pré-admissionais periódico em cada trabalhador. O empregado que sofrer trauma dental ou maxilar deve ser atendido pelo cirurgião-dentista industrial, ou ser encaminhado para um especialista. Cabe ao cirurgião-dentista industrial ser claro quanto à severidade do trauma, à duração da incapacidade temporária, ao grau de incapacidade permanente, estabelecer os custos do tratamento e da reabilitação, além de conhecer as manifestações bucais de doenças profissionais.

No livro Medicina Bucal: Diagnóstico y Tratamiento, Burket (1954) descreve as lesões bucais causadas por agentes químicos, físicos e mecânicos. E ressalta a importância da contribuição do cirurgião-dentista no programa geral de higiene industrial que, além de um serviço de profilaxia dental, pode contemplar o diagnóstico e o tratamento de traumatismos da boca e dos maxilares. Como vantagens, o autor cita a diminuição do absenteísmo e do risco de acidentes de trabalho decorrente da melhoria das condições de saúde bucal. 
Em 1955, Morvay escreveu sobre os deveres do cirurgião-dentista e do médico industrial quando diante de traumas dentais e maxilares. $\mathrm{O}$ médico deve estar familiarizado com procedimentos de emergência em acidentes que causem fratura de mandíbula ou perda de dentes caso não haja cirurgião-dentista na indústria, ou até que este chegue ao local.

Camp (1955) relata o funcionamento do serviço odontológico da empresa de vidro Corning, implantado em 1925 e que atendia a cerca de 7000 empregados. O autor observou que havia conformidade com as normas da ADA e da sociedade dental do Estado de Nova lorque e que, apesar da não existência de dados a esse respeito, a redução do absenteísmo causado por dores de dentes e doenças causadas por infecção dental diminuiu.

Em um capítulo sobre as manifestações bucais de doenças dentais e bucais de origem ocupacional por agentes químicos, físicos e biológicos, Salzmann (1957) aborda a importância de o cirurgião-dentista industrial ter uma formação especial, voltada à prevenção, ao diagnóstico e ao tratamento das manifestações bucais de doenças profissionais e que faça com que ele seja capaz de atuar em acidentes do trabalho que atingem as estruturas da cavidade bucal. $\mathrm{O}$ autor também descreve o programa de odontologia industrial preconizado pela Divisão de Higiene Industrial do Instituto Nacional de Saúde do Serviço de Saúde Pública dos Estados Unidos da América.

Knudtzon (1957) traçou um histórico da odontologia da aviação, e também citou os principais problemas - decorrentes das condições de vôo que afetam o complexo estomatológico, como a aerodontalgia; a 
aerosinusite; e os problemas periodontais, protético, de perdas de restauração.

Na segunda edição do livro de Desoille, Dechaume \& Garlopeau (1957) classificam as lesões decorrentes de problemas ocupacionais em: lesões da mucosa bucal, lesões alvéolo-dentárias, lesões dentárias e lesões dos maxilares por problemas ocupacionais. Descreveram as lesões bucais por traumas, por agentes físicos, químicos e a prevenção através das medidas profiláticas enfatizando a colaboração do trabalhado, da direção da empresa e da medicina.

Prosseguindo a sua linha de pesquisa, voltada a lesões dentárias e maxilares, Morvay publicou, em 1957, trabalho no qual elenca as condutas que o perito cirurgião-dentista deve seguir em casos de reclamação de compensação na área odontológica considerando que, naquela época, as leis sobre esse assunto variavam de estado para estado. Além dos aspectos técnicos, o autor também recomenda que o profissional adote uma postura eminentemente ética não somente no que concerne à extensão da injúria e seu prognóstico, como também no que diz respeito ao justo pagamento de reparos ou reposições.

Brock (1958) discute a relação entre o cirurgião-dentista industrial e o clínico geral na coordenação do programa odontológico industrial. O autor lembra que é fundamental que odontologia industrial esteja integrada ao programa de saúde industrial. Para ele, a odontologia industrial deve ser uma "especialidade odontológica que se preocupa com a saúde dental do trabalhador industrial, e como esta influencia ou é influenciada por sua saúde geral 
e seu ambiente de trabalho", e o cirurgião-dentista deve ter qualificação e experiência na área, mediante treinamento prévio.

Relatando a experiência de quarenta anos do programa odontológico de um estabelecimento varejista, Greenwood (1958) descreve que os procedimentos que tal programa contemplava: exame préadmissional, educação do paciente, preenchimento de ficha odontológica, encaminhamento do paciente para cirurgião-dentista particular e cuidados emergenciais. E conclui que um efetivo serviço odontológico preventivo industrial reduz as perdas de produção decorrentes de causas ocupacionais, aumentando a saúde geral e moral dos empregados.

Para Arbenz (1959), algumas alterações das estruturas dos dentes como fraturas, desgastes, luxações, cáries profissionais, perda de brilho, aerodontalgias, etc. - podem propiciar a identificação da ocupação do indivíduo, pois são características de determinadas profissões.

A sociedade odontológica deve atuar na saúde ocupacional com vistas à melhoria da saúde dental do indivíduo - que é parte da sua saúde total -, preconiza Dougherty (1959). Assim, deve procurar estender os cuidados odontológicos a todas as pessoas que trabalham, propondo formas de pagamento acessíveis aos interessados como resultado da cooperação entre profissionais de saúde, administradores e empresa.

Avaliando 388 trabalhadores, Pimentel et al. (1961) constataram grande necessidade de cuidados dentários, principalmente da instalação de próteses. Isto porque grande parte dos trabalhadores, devido aos baixos salários, acaba optando pela extração dentária ao invés do tratamento. 
Assim, os autores sugerem a instalação de consultórios odontológicos nas indústrias como uma das soluções para tal problema.

Em trabalho sobre a necrose dos maxilares por fósforo que afeta os trabalhadores que manipulam fósforo branco, Hughes et al. (1962) descrevem dez casos com histórico, radiografias e procedimentos realizados; também citam outros seis casos que, embora apresentando sinais precoces, não desenvolveram a patologia, apresentando pequena ou nenhuma perda de osso.

Medeiros (1965) recomenda que o exame odontológico préadmissional deve ser realizado pelo cirurgião-dentista, pois este está "apto a avaliar com maior profundidade quais outros dentes ou partes moles merecem atenção antes do ingresso", e apresenta os benefícios desse procedimento, como a eliminação dos dentes com extração indicada antes da admissão, o diagnóstico precoce de doenças com manifestação oral, e a diminuição do absenteísmo.

Em 1965, o Serviço Social da Indústria (SESI) descreveu o seu Serviço de Odontologia Ocupacional e, exemplificando o seu modelo de ficha clínica e anamnese, apresentou um caso de suspeita de erosão do esmalte dentário por anidrido sulfuroso. Esse documento também arrola algumas manifestações bucais relacionadas a agentes químicos como ácido crômico, ácido sulfúrico, ácido tartárico, ácido fluorídrico, farinha, arsênico, fósforo, chumbo e mercúrio.

Discutindo a relação entre o Serviço de Saúde Nacional da Inglaterra e a odontologia industrial daquele país, Cowell (1966) comenta que a 
odontologia industrial teria mais tempo para despender na educação preventiva. Aponta que o Serviço de Saúde Nacional necessita incrementar as atividades voltadas à educação preventiva, e que a simples remoção da barreira econômica que dificulta o tratamento odontológico não resultará em pacientes ávidos para manter seus dentes. $O$ autor conclui que, embora seja difícil satisfazer a todas as partes envolvidas - o legislador, o ministério, a população e os profissionais da odontologia -, é necessário tentar. E sugere uma boa distribuição geográfica de dentistas, por incentivos de pagamento para áreas com pouco profissionais; a promoção de atividades de prevenção de doenças odontológicas; a priorização do atendimento a crianças e gestantes; a inclusão do serviço odontológico no serviço de saúde ocupacional e a liberdade de alinhamento com uma plataforma política.

Medeiros (1966) conceituou a Odontologia do Trabalho como "o setor da Odontologia que tem por finalidade a melhoria da saúde oral, seus efeitos e influência sobre a produtividade no trabalho e o diagnóstico precoce de manifestações orais de doenças ocupacionais". E cita as funções e os objetivos do serviço odontológico na indústria.

Em seu livro Forensic Odontology, Furuhata \& Yamamoto (1967) dedicam um capítulo às patologias e/ou mudanças morfológicas resultantes das ocupações profissionais, e descrevem aquelas de origem química e de origem mecânica. Pelo exame dos dentes pode-se presumir a ocupação do trabalhador sendo muito importante em casos de perícia criminal.

Pesquisando as leis de compensação para injúrias dentais e maxilares de 45 estados americanos entre 1953 e 1959, Morvay et al. (1967) 
concluíram que, apesar de cada estado elaborar sua legislação, havia uma certa tendência à uniformidade. A maior parte dos estados - 40 - tratava as injúrias dentais como qualquer outra injúria física permanente; 38 estados consideravam o empregador responsável pelo agravamento das condições dentais resultantes de acidente industrial; os dentistas tinham os mesmos privilégios dos médicos consultores em procedimentos como exames, radiografias etc.; as injúrias dentais mereciam especial atenção. Os autores concluem ressaltando que a classe odontológica e a sociedade devem se fazer ouvir para assegurar uma adequada atenção para o problema.

Na Inglaterra Cate (1968) examinou, entre março de 1962 e outubro de 1964, 555 trabalhadores que manipulavam ácidos em indústrias, principalmente aquelas que fabricavam baterias. Encontrou erosão dental em $31,7 \%$ dos trabalhadores - destes, 6,0\% (33 casos) apresentavam erosão também na dentina, e 27 das 114 erosões $(23,7 \%)$ foram consideradas desfigurantes. O autor conclui ressaltando que o uso de recipientes fechados de ácidos e outros métodos previnem a contaminação atmosférica e diminuem a prevalência da erosão, além do uso de muros de vento e agentes detergentes espumantes.

L’épée et al. (1969) enfatizam a importância de se incluir um sistemático exame buco-dentário nos exames periódicos em medicina do trabalho, e descreve a metodologia e o instrumental necessários para a sua realização.

Em 1969, Thiess relatou a história dos cem anos do departamento médico da BASF, na Alemanha. $O$ autor conta que o mais antigo 
departamento médico dessa empresa data de 1866, e que em 1969 os dentistas ocupacionais não só inspecionavam e tratavam os trabalhadores jovens como também preveniam a cárie dental, as doenças periodontais e os efeitos deletérios que algumas substâncias causam nos dentes em todos os empregados.

Para Medeiros \& Bijella (1970), o serviço odontológico deve estar presente na indústria. Os autores também reforçam a importância de manutenção do fichário para fins de tratamento, estatística e pesquisa, além de sugerirem um programa de implantação de odontologia industrial.

Em 1971, os mesmos autores - Medeiros \& Bijella - publicaram trabalho no qual sugerem modificações nos critérios de planejamento e na rotina de atendimento de serviços de odontologia industrial. Os autores preconizam que o tratamento deve ser realizado no local de trabalho e que $o$ planejamento deve ser baseado nas necessidades dos trabalhadores contemplando dados epidemiológicos, dados projetados de tempo de atendimento, utilização de pessoal auxiliar e trabalho em duas cadeiras, além da educação em saúde bucal.

Em estudo sobre a prevalência dos problemas de saúde em 4643 trabalhadores de 101 indústrias do Egito, Batawi (1972) observou que a cárie dental e a doença periodontal apresentavam grande incidência, concluindo que cuidados odontológicos na indústria são importantes, mas que a educação em saúde e os hábitos de higiene devem ser sempre encorajados. 
Carryer et al. (1972) estudaram 569 executivos de 32 companhias americanas, verificaram a ocorrência de doenças e constataram a vantagem do exame periódico para a detecção de doenças ainda em fase reversível, como a leucoplasia oral e as doenças da laringe, que são extremamente malignas e que, na pesquisa, atingiram 13 pacientes; também identificaram um paciente com carcinoma de glândula salivar e outro com carcinoma de lábio.

Em trabalho publicado em 1972, Nogueira lembra que a cavidade bucal é muito vulnerável por causa da comunicação com o meio externo. Assim, é de fundamental importância o reconhecimento e a prevenção dos riscos ambientais que apresentam manifestações orais, e a correção das lesões existentes, o que requer a presença de um cirurgião-dentista dentro da equipe de saúde ocupacional. E, para contribuir com essa ação preventiva, o autor descreve, de forma geral, as manifestações bucais provocadas por agentes físicos, químicos, biológicos e mecânicos.

Em uma revisão da literatura sobre pigmentação da mucosa bucal por chumbo, Bruggenkate et al. (1975) analisaram a patogênese, os sintomas clínicos e as manifestações bucais. Relataram o caso de um pintor de 38 anos que apresentava a linha de Burton, e concluem que o exame odontológico pode ajudar na diferenciação entre a intoxicação por chumbo e a intoxicação por bismuto, cujo quadro médico é bastante semelhante.

Sbrissa Netto et al. (1975) estudaram vinte e dois trabalhadores que estavam expostos ao chumbo. Destes, oito casos - que apresentavam 
quadro inflamatório gengival - tiveram confirmação histológica, dois acima do limite de tolerância.

A importância do exame pré-admissional em trabalhos com ar comprimido como tubulões, caixões pneumáticos e túneis pressurizados foi destacada por Matos \& Leão (1975). Os autores preconizam a realização de exames odontológicos completos para a seleção e o acompanhamento de mergulhadores e também de trabalhadores que desenvolvam outras atividades hiperbáricas.

Desoille et al. (1975) descrevem lesões da mucosa bucal e das regiões vizinhas por ação direta ou indireta; lesões alvéolo-dentárias; lesões dentárias traumáticas, coloração dos dentes, modificações patológicas dos dentes, cárie dentária profissional, intoxicação crônica por flúor, lesões bucodentárias em aviadores; e lesões dos maxilares na ósteo-radionecrose demonstrando a importância do diagnóstico das manifestações bucais das doenças profissionais em medicina do trabalho.

Para Pimentel (1976), é necessário que a odontologia do trabalho esteja presente na equipe de segurança do trabalho, pois sua atuação só trará vantagens a todas as partes envolvidas: o operário, a indústria e o governo. Esta é, para o autor, a única maneira de equilibrar o bem-estar do trabalhador e o desenvolvimento da produção industrial.

Estudando 333 pacientes com síndrome de dor-disfunção miofacial, Helöe et al. (1977) constaram que o fator de estresse mais relatado foi a situação de pressão no trabalho (30\%), seguido pelos períodos de condições de trabalho estressantes (14\%). 
Skogedal et al. (1977) estudaram 12 trabalhadores de uma fábrica da Noruega que utilizavam métodos eletrolíticos à base de ácido sulfúrico, sulfato de zinco e outros ingredientes para extrair o zinco. Constataram relação entre grau de erosão, número de dentes afetados e tempo de serviço - quanto maior o tempo de trabalho, maiores eram a erosão e o número de dentes afetados. O diagnóstico clínico da erosão foi mais eficiente que o diagnóstico realizado por meio de slide colorido, no qual a erosão de grau 1 não foi detectada.

Para avaliar as condições de saúde bucal de trabalhadores expostos ao mercúrio, Fahmy (1978) examinou 222 trabalhadores do Kwait e encontrou várias manifestações bucais como estomatite, glossite, ulceração da gengiva, linha azulada de mercúrio, sangramento da gengiva etc. Entretanto, não observou correlação entre os sintomas e sinais e o tempo de exposição, o que levou-o a concluir que a doença bucal por exposição ao mercúrio deve-se à negligência com a higiene bucal, à exposição ao mercúrio, à falta de supervisão bucal e de adequado tratamento odontológico. Assim, sugere que o exame e o apropriado tratamento bucal devem ser realizados antes da admissão e em avaliações periódicas.

Para avaliar os cuidados que as pessoas dedicam aos dentes, Rajala et al. (1978) estudaram 256 empregados de uma fábrica de papel na Finlândia e constataram que $46,1 \%$ (118) visitavam irregularmente o dentista, 37,7\% (101) iam ao dentista por causa de dores-de-dente e somente $9,3 \%$ (25) realizavam exames de rotina. Os autores concluíram que 
as pessoas mais jovens utilizam mais o serviço dentário, e que os trabalhadores administrativos freqüentam o dentista com maior regularidade.

Anaise (1978) avaliou 722 trabalhadores da linha de produção, com mais de vinte anos de idade, de uma indústria de doces (duas padarias e duas fábricas de doces), e um grupo controle composto por 812 trabalhadores da linha de produção de cinco indústrias têxteis. O autor verificou que o índice CPOD dos trabalhadores das indústria de doces $(15,59)$ foi significativamente maior do que aquele do grupo controle $(9,14)$, e que o índice CPOD dos trabalhadores da indústria de doces que trabalhavam há mais de 10 anos $(17,28)$ foi significativamente mais alto do que o daqueles que trabalhavam na indústria de doces há um período de 3 a 10 anos $(14,65)$ ou abaixo de 3 anos $(12,72)$.

Analisando as manifestações gengivais, dentárias e glandulares da intoxicação ocupacional por chumbo e a erosão dentária decorrente dos ácidos utilizados na indústria, Birman (1979) ressalta a importância da presença do cirurgião-dentista nas indústrias para promover e manter a saúde bucal dos trabalhadores.

Katz et al. (1979) conduziram um estudo epidemiológico de acidentes traumáticos dento-faciais, durante 9 meses, em 16 batalhões do exército dos EUA, numa população de risco de 210.500 soldados. No período estudado, foram registrados 596 casos de lesões dento-faciais que, numa projeção para doze meses, resultou na razão de 37,7 pessoas/10.000/ano. As principais causas dos danos foram as lutas marciais $(29,8 \%)$, os esportes $(22,3 \%)$, os veículos $(13,9 \%)$, as armas $(7,0 \%)$ e outros 
equipamentos $(5,9 \%)$. Os autores concluíram que a razão varia de acordo com os sub-grupos específicos com fatores de alto risco como em homens jovens, patentes mais baixas, recrutas recentes e postos de treinamento de combate.

Discutindo as manifestações clínicas, os procedimentos diagnósticolaboratoriais, a patogênese, os critérios de diagnóstico e o tratamento do saturnismo, Gordon et al. (1979) utilizam o relato de um caso. E concluem que, apesar das dificuldades no diagnóstico, o cirurgião-dentista pode ser o primeiro membro da área da saúde a ser consultado pelo paciente, de forma a possibilitar uma detecção precoce das manifestações de doenças ocupacionais.

Nos volumes do Curso de Medicina do Trabalho da Fundacentro, diferentes autores descrevem as doenças profissionais que apresentam manifestações bucais: Andrade (1979b), Bedrikow (1979) e Kitamura (1979a) falam sobre os problemas decorrentes da exposição ao mercúrio; Belliboni aborda o câncer labial (1979); Andrade traz informações sobre a exposição ao arsênico (1979a); Kitamura fala sobre o contato com fósforo (1979b); Gomes sobre o chumbo (1979); e Nascimento Filha sobre fumos metálicos (1979).

Pizzaro (1979) descreve a relação entre o trabalho e os órgãos dos sentidos, e aborda as manifestações de doenças profissionais na língua e nas outras partes da cavidade bucal. Como outros médicos, enfatiza as lesões de agentes químicos, físicos e mecânicos na cavidade bucal. 
Discutindo a organização de serviços odontológicos em empresas, Guimarães \& Rocha (1979a) ressaltam a importância da boca nos aspectos psicológico, funcional e anatômico do indivíduo. E conceituam a odontologia do trabalho como "a parte da Odontologia que trata de promover, preservar e reparar a saúde do trabalhador, conseqüente dos agravos, afecções ou doenças advindas do exercício profissional e que se manifestam na boca". Também abordam as manifestações bucais das doenças profissionais, e as vantagens da implantação desse serviço para a empresa, o trabalhador e o país.

Na segunda parte do mesmo trabalho, Guimarães \& Rocha (1979b) postulam a inclusão da odontologia na equipe de saúde industrial, e apontam as competências e funções do programa de odontologia na empresa.

Ainda em continuidade - terceira parte - a esse estudo, Guimarães \& Rocha (1979c) apresentam as funções do cirurgião-dentista. Também comparam as experiências da Rede Ferroviária Federal S/A (RFFSA) e da Petrobrás com serviços odontológicos, e concluem que não há como eleger um melhor serviço pois a eficácia, eficiência e abrangência de cada serviço depende dos recursos que a empresa disponibiliza para o projeto.

Waldman (1979) analisou a inserção da odontologia no Serviço Nacional de Saúde da Inglaterra e constatou que o serviço dental industrial empregava cerca de 200 cirurgiões-dentistas para tratar os empregados.

Para avaliar a influência de programas de instrução em higiene bucal e profilaxia bucal sobre o conhecimento, a atitude e o comportamento do 
indivíduo, Tan (1979) realizou um estudo com 96 soldados alemães. Concluiu que a instrução em higiene bucal aumenta o conhecimento sobre a importância do complexo bucal mas não muda o comportamento preventivo geral, e que a combinação de programas desse tipo com profilaxia bucal melhora a sua efetividade, influenciando positivamente o conhecimento e 0 comportamento do indivíduo.

Rocha et al. (1979) comentam a importância da análise profissiográfica com base na experiência da RFFSA, empresa em que vários profissionais, incluindo o cirurgião-dentista, buscam uma melhoria do processo seletivo de empregados adotando a avaliação técnica e objetiva; maior proteção do trabalhador contra os agravos laborativos; maior desempenho produtivo; e diminuição dos acidentes do trabalho.

Trabalhadores submetidos a condições hiperbáricas podem desenvolver doenças como o barotrauma dentário, e fatores dentários como a má-oclusão dentária - podem levar à oclusão da trompa, denominada barotrauma de ouvido médio (Mendes, 1980).

Estudando as manifestações bucais do saturnismo, Esteves et al. (1980) utilizaram uma amostra de 93 prontuários médicos de pacientes do Serviço de Medicina Industrial da Sub-Divisão de Higiene e Segurança Industriais do SESI de São Paulo. E relatam que a linha de Burton foi constatada em 22 pacientes (23,65\%) de diferentes ocupações, de idades entre 20 e 30 anos, faiodermas e com condições bucais péssimas. Desta forma, ressaltam a importância da inserção do cirurgião-dentista na equipe de Medicina Industrial. 
Gomes \& Magalhães (1980) descrevem a experiência da RFFSA com o Censo Bucal, que abrangeu 1110 (82\%) empregados dos 1350 efetivos e serviu para o planejamento do serviço odontológico. Os autores enfatizam a importância da colaboração de todos os funcionários - sem distinção hierárquica - para a obtenção de benefícios que atinjam tanto o empregador quanto os empregados.

Comungando com a preocupação que empresas, governo e profissionais manifestam com relação às conseqüências do absenteísmo no processo de produção e com a saúde do operário, Tenório \& Jordano (1980) avaliaram as taxas de freqüência e de gravidade dessas ocorrências. Encontraram que, em 1976, as causas odontológicas foram responsáveis por $27,27 \%$ das faltas ao trabalho e, no ano seguinte, por $30,72 \%$. E sugerem, para diminuir o absenteísmo: exames pré-admissionais mais criteriosos; estruturação de serviços médicos que atendam às necessidades básicas dos empregados, evitando idas desnecessárias ao INAMPS etc.

Para Carvalho (1981), a necessidade de inserção da odontologia do trabalho em programas de higiene e saúde fica clara quando se consideram as repercussões bucais das várias intoxicações e as alterações das estruturas da boca por fatores patogênicos locais.

Graziani (1982) comenta o aumento do número de acidentes de trabalho que resultam em traumatismos na região buco-maxilo-facial, e relata um caso de acidente em que um operário foi atingido por um prego disparado acidentalmente por um aparelho pneumático usado na construção 
civil para cravar pregos no concreto. Esse prego atingiu a face do trabalhador, passou pelo malar e alojou-se na cavidade sinusal.

Em uma revisão sobre a relação estresse-bruxismo em que abordou a terminologia, o diagnóstico, a incidência, a etiologia e a terapia dessa manifestação, Morse (1982) relata o caso de um paciente que era cirurgiãodentista e apertava os dentes em várias circunstâncias, como por exemplo, quando estava fazendo um procedimento em um tratamento difícil, ou quando tinha uma desavença com um sócio.

Para avaliar a freqüência de ruído e de dores da Articulação Têmporo-Mandibular (ATM), Hirsch et al. (1982) avaliaram 56 músicos - 30 homens e 36 mulheres, 51 violeiros e 15 violinistas - e 87 homens e 28 mulheres estudantes de odontologia - e observaram maior incidência dessa manifestação na classe estudada - qual seja, a de músicos -, e índices mais altos nos violeiros do que nos violinistas que tocavam há um mesmo número de anos na mesma quantidade de horas semanais. A limitação do movimento mandibular, e o desvio da mandíbula em abertura para a direita foi significativamente maior nos músicos que na população de estudantes que não exercia esse tipo de atividade, o que sugere que tais problemas podem ter uma origem ocupacional.

Birman et al. (1982) relatam um caso raro de pigmentação labial por chumbo em uma trabalhadora leucodérmica, com dez meses de atividade na função de ajudante de produção de uma indústria de cerâmica. E ressaltam a importância de que o diagnóstico de manifestações bucais de doenças profissionais seja realizado pelo cirurgião-dentista, além da grande 
colaboração que esse profissional pode trazer à equipe de saúde na manutenção de condições bucais que evitem a destruição e a perda dos dentes - que trazem graves conseqüências para a fisiologia bucal e para a saúde geral do trabalhador.

Para Esteves (1982), a participação do cirurgião-dentista na equipe da Saúde Ocupacional não se prende apenas à sua competência para detectar manifestações bucais de agentes químicos, mas também à sua capacidade de identificar patologias que diminuem a resistência do trabalhador, como os focos dentais infecciosos, os fatores pré-cancerígenos etc. E, para auxiliar os profissionais ligados a esse tipo de atividade, descreve as características dos tecidos bucais sadios e as características dos tecidos bucais quando agredidos pelos agentes químicos.

Em capítulo dedicado às lesões físicas e químicas que ocorrem na cavidade bucal, Shafer et al.(1983) destacam a radiação e as lesões por agentes como o fenol, o bismuto, o chumbo etc. enfatizando que, embora o diagnóstico precoce e o tratamento da doenças ocupacionais sejam importantes, a prevenção deve ser o foco central.

Graziani (1983) relata que tanto a mandíbula quanto a maxila são sede de traumantismos, principalmente nos homens, devido à natureza de suas ocupações. Os acidentes automobilísticos também aumentam a cada ano, e uma parcela deles provavelmente é considerada acidentes de trabalho, pois pode ocorrer durante 0 trajeto para $\circ$ trabalho ou durante 0 serviço. 
Estudando o padrão de utilização do serviço dentário, a percepção de doença periodontal e os hábitos de higiene de 642 trabalhadores do sul da Austrália, Srikandi et al. (1983) encontraram que 40,1\% dos trabalhadores visitaram o dentista no período compreendido entre 1 e 5 anos anteriores à pesquisa, que a perda de número de dentes aumentava com o avançar da idade, e que $89 \%$ da amostra apresentava periodontite.

Em trabalho desenvolvido para avaliar as condições de saúde bucal de 59 trabalhadores de uma indústria de chocolates da Dinamarca em comparação com os dados de um grupo de trabalhadores do estaleiro, Petersen (1983) constatou que o índice de CPOD aumentava sensivelmente com o aumento da idade, que a concentração de açúcar no ar, dentro da indústria, era de 3 a 40 vezes maior do que o permitido na Dinamarca, e que poucos dos sujeitos escovavam os dentes no trabalho. Um quarto dos entrevistados declarou consumir chocolate no ambiente de trabalho, e os indivíduos que trabalhavam na fábrica de chocolates apresentavam maiores índices de cáries e de doenças periodontais que o grupo de trabalhadores do estaleiro. Desta forma, o autor conclui que os trabalhadores de fábricas de chocolate são um grupo de alto risco para as patologias citadas, e que é necessário reduzir a concentração de açúcar no ar e estabelecer um programa de saúde bucal preventivo dentro do serviço de saúde ocupacional em indústrias de chocolate.

Discutindo a saúde ocupacional e a inserção da odontologia em programas dessa modalidade, Silva \& Souto (1983a) entendem a odontologia ocupacional "como sendo a aplicação de todos os recursos técnicos- 
científicos possíveis na Odontologia na promoção e preservação do bem-estar físico, psíquico e social do homem no seu trabalho, reconduzindo-o a este estado, quando necessário".

Na segunda parte do mesmo trabalho, os autores - Silva \& Souto (1983b) recomendam que o programa de odontologia ocupacional deve contemplar exames pré-admissionais, exames periódicos, censos odontológicos, levantamento de perfis profissiográficos e participação em programas ergonômicos, além de campanhas educativas.

Finalizando o citado estudo, Silva \& Souto (1983c) enfatizam a importância da odontologia ocupacional, e concluem que a assistência ao trabalhador deve ser atribuição da empresa - que deve prover também a assistência odontológica no âmbito da saúde ocupacional, dada a estreita relação existente entre as patologias do complexo estomatognático e a gênese de acidentes do trabalho e o absenteísmo.

Quando estudaram as condições dentárias de 345 trabalhadores de uma indústria de cerâmica, Ferraz \& Bellini (1983) encontraram grande número de dentes extraídos. Os autores constataram que os trabalhadores “tinham uma oferta gratuita de extrações no serviço odontológico da indústria”, e o dentista encarregado relatou que, normalmente, recebia solicitações para realizar extrações mesmo em dentes com cáries simples. Isto explica o aumento de desdentados totais para as faixas etárias acima de 35 anos.

Para planejar e avaliar a eficiência do serviço odontológico em uma indústria mecânica de médio porte, Motta \& Albuquerque (1983) examinaram 1257 empregados após catorze meses de implantação do programa. Os 
autores constaram bons resultados: 1183 (94\%) trabalhadores haviam sido atingidos pelo plano, e houve redução de $28,55 \%$ do índice de incidência de cáries dentárias.

Para Passos \& Villela (1983), a literatura registra poucos trabalhos sobre a odontologia do trabalho. Desta forma, e com base em sua experiência de atuação de 13 anos nessa área, os autores apresentam as manifestações bucais de doenças profissionais por agentes físicos, químicos, mecânicos e biológicos. Concluíram que é importante o conhecimento das substâncias manipuladas pelos trabalhadores para um diagnóstico precoce e tratamento das doenças profissionais, aumentando a saúde e produtividade do trabalhador.

No livro Odontologia Legal y Practica Forense, Briñon (1984) faz uma proposta pessoal sobre avaliação pericial das lesões bucais em casos de acidentes do trabalho e doenças profissionais, e cita um caso de perícia referente à perda de elementos dentários que realizara em foro trabalhista no qual, utilizando os parâmetros propostos, calculou o custo do tratamento que o trabalhador deveria seguir.

Paiva \& Antoniazzi (1984) descrevem a sintomatologia dolorosa que pode ocorrer em dentes sob tratamento ou recém-tratados, com alteração pulpar discreta ou transitória assintomática no solo, mas que pela variação de altitude ocorre mudança de pressão podendo originar no dente, dor. $\mathrm{O}$ barotrauma dental (aerodontalgia), que pode se manifestar em pessoas que trabalham em atividades hiperbáricas, como os mergulhadores e os aviadores. 
Segundo os autores No livro Patologia Bucal, Araújo \& Araújo (1984) citam a pigmentação exógena sistêmica de origem ocupacional da mucosa bucal decorrente da exposição ao chumbo, ao mercúrio, à prata e ao bismuto.

Em 1984, Motta \& Toledo (1984) reavaliaram o serviço odontológico da indústria analisada por Motta e Albuquerque em 198312 meses após o primeiro trabalho, totalizando 26 meses de resultados. A abrangência do programa aumentou, contemplando 1705 indivíduos nesse segundo estudo, mas há que se considerar que, nesse aumento - de 355 empregados (1705 em 1984 - 1350 em 1983) -, estavam incluídos a rotatividade de recursos humanos. De qualquer maneira, os autores obtiveram como resultado um alcance de 90,2\% (1538) empregados, e uma conservação de dentes da ordem de $85,39 \%$, considerados excelentes.

Reisine (1984) entrevistou 2527 trabalhadores, dos quais 58,7\% eram do sexo masculino. Destes, $25 \%$ responderam ter perdido horas de trabalho por problemas dentais nos últimos 12 meses, com média de 1,7 horas perdidas. $\mathrm{O}$ autor conclui que um serviço preventivo pode promover uma relação custo-benefício favorável, implicando a redução dos custos indiretos, da perda de tempo de trabalho e possibilitando a utilização dos dados registrados como indicadores adjuntos para pesquisas odontológicas.

Sonis et al. (1985) comentam que os metais pesados, como o chumbo e o bismuto, podem se depositar na gengiva marginal quando em níveis sistêmicos elevados. Apesar da pigmentação ser de pequena 
importância clínica, são importantes para o diagnóstico de intoxicação por metais pesados.

Estudando uma amostra de 50 pacientes voluntários, todos do sexo masculino e dentro da faixa etária compreendida entre 23 e 74 anos, Green et al. (1986) realizaram exames orais para determinar os índices de gengivite e de periodontite e o grau de estresse decorrente de eventos da vida, e observaram correlação significativa entre tais eventos e as citadas manifestações. Assim, concluíram que a doença periodontal humana está relacionada aos eventos da vida, e que pessoas com forte tendência à somatização são particularmente predispostas a manifestar essa patologia.

Para Garrafa (1986a), a odontologia do trabalho teria como objetivos "o estudo, interpretação e solução dos diferentes problemas bucais que atingem a todos trabalhadores, visualizados como participantes do processo de produção e consumo de bens, incluindo-se os próprios trabalhadores do setor saúde”. O autor ressalta a importância das doenças profissionais e dos acidentes de trabalho que atingem a região buco-maxilo-facial, e postula que é chegado o momento de a odontologia cumprir sua parcela de responsabilidade na busca de caminhos alternativos para melhorar as condições de vida da população brasileira.

Nessa mesma linha de trabalho, Garrafa (1986b) procurou enfatizar a importância da odontologia do trabalho como uma nova especialidade dentro da odontologia e “como a própria Medicina do Trabalho aplicada à área estomatológica, com responsabilidade pelo estudo, compreensão e solução dos problemas bucais inerentes aos trabalhadores". 
Em estudo realizado em 1986, Enbom et al. (1986) estudaram 54 homens que trabalhavam em minas e dividaram-nos em dois grupos: um com trabalhadores de 5 a 7 anos de trabalho e com trabalhadores que trabalhavam há 10 anos, comparando-os com 2 grupos controle de trabalhadores administrativos. De acordo com os resultados, os grupos de mineiros tinham maior grau de desgaste oclusal - com variação estatística significativa - que os grupos controle; os mineiro mais antigos apresentavam maiores deficiências quanto à higiene bucal, maiores índices de desgaste oclusal, e sinais de disfunção mandibular. Os autores concluíram que a diferença entre os grupos de mineiros e os grupos controle está relacionada ao ambiente de trabalho, pois os mineiros atuam em locais que têm componentes abrasivos no ar, o que provoca o desgaste oclusal.

Ayer et al. (1986) apresentam um histórico da odontologia nas indústrias no qual citam, como o primeiro sistema de cuidados odontológicos destinado aos trabalhadores na Inglaterra, aquele implantado pela Great Western Railway of England, em 1887. Os autores sistematizam a implantação de um programa de promoção de saúde dental no ambiente de trabalho que contempla desde o desenho do projeto até a sua implementação, enfatizando a importância da presença do cirurgião-dentista nessee processo.

Para avaliar importância que as pessoas atribuem à aparência dental, Jenny \& Proshek (1986) estudaram a opinião de cinco grupos de pessoas - num total de 484 indivíduos - de 88 diferentes ocupações. Concluíram que as ocupações de prestígio e/ou que requerem constante 
exposição ao público requerem boa estética dental, e que a sociedade estabelece padrões de aparência dental aceitáveis, o que faz com que desvios desses padrões reduzam as oportunidades do indivíduo no mercado de trabalho.

Para Marano (1987), as fichas de exame médico pré-admissional devem também contemplar dados de otorrinolaringologia, oftalmologia ortopedia e odontologia. E postula que, quando do exame da cavidade bucal, o profissional deve indicar a remoção de focos e restaurações, além de dedicar especial atenção às próteses, que podem encobrir lesões précancerosas.

Nysether (1987) estudou injúrias dentárias em jogadores de futebol da Associação de Futebol da Noruega de 1979 a 1983. Encontrou 20\% (1267) de traumas dentais - a maioria presente em esportistas do sexo masculino - com uma relação de 13,5 injúrias por 10.000; a maior parte desses traumas era constituída de fraturas de coroa não complicadas (45\%), seguida de fraturas de coroa complicadas $(20 \%)$ e sub-luxação e luxação (10\%). Apesar de a prevalência ser baixa em relação ao total de jogos, esses traumas podem se tornar uma desvantagem para a vida do atleta.

Em estudo realizado em 1987, Hahn colheu 210 questionários e, numa segunda fase, mais 307 questionários, complementados por exames clínicos, em uma população de trabalhadores. Concluiu que a saúde bucal e os hábitos de higiene da amostra eram precários, e analisou o custo do transporte - por helicóptero - desses trabalhadores para tratamento, 
comprovando que esse era quatro vezes menor que o custo das ocorrências de resgate no ano de 1984.

Arbenz (1988) descreve as alterações dentárias profissionais, abordando as fraturas profissionais, as luxações, os desgastes, as cáries profissionais, a perda de brilho, a odontólise e as modificações de coloração que, sob o ponto de vista pericial, podem ser utilizadas para a identificação da profissão do indivíduo.

No livro Diagnóstico em Patologia Bucal, Tommasi (1988) relata a pigmentação da mucosa bucal por metais pesados, como o bismutismo, o plumbismo ou saturnismo, o hidrargismo e a argiria, a cárie de confeiteiro e a cárie de radiação, como sendo importantes sinais para o diagnóstico de intoxicação ou doenças profissionais pelo cirurgião-dentista.

Em revisão sobre a odontologia ocupacional na Inglaterra, Feaver (1988) relata que o primeiro serviço odontológico em indústria data de 1889 e foi implantado pela Great Western Railway Medical Found Society. O autor descreve a organização do serviço e as suas funções, e postula que o cirurgião-dentista ocupacional deve trabalhar integrado a outras disciplinas do campo da saúde ocupacional para, efetivamente, melhorar o bem-estar dos trabalhadores e maximizar os recursos do departamento de saúde ocupacional.

Diacov \& Lima (1988) estudaram o absenteísmo decorrente de problemas odontológicos em 701 trabalhadores da prefeitura municipal de São José dos Campos, e concluíram que ele é maior nos homens, nos trabalhadores que exercem funções burocráticas, na faixa etária de 20 a 30 
anos de idade, e que os trabalhadores mais velhos apresentam menores índices de absenteísmo.

Analisando a razão de mortalidade proporcional (PMR) em uma amostra de 1071 trabalhadores de indústrias de papel em Nova Hampshire que foram a óbito durante o período de 1975 a 1985, Schwartz (1988) encontrou um aumento estatisticamente significativo para o câncer da cavidade bucal $(\mathrm{PMR}=175,90 \%)$.

Petersen (1988) avaliou qualitativa e quantitativamente o processo de elaboração de programas odontológicos preventivos - dentro do Serviço de Saúde Industrial (SSI) - de duas fábricas de chocolate dinamarquesas. Concluiu que tanto os empregados quanto a administração das empresas estavam satisfeitos com o programa, e sugere a utilização da pluralidade de métodos como princípio para a pesquisa em odontologia social.

Em 1988, Borrás \& Sanfilippo (1988) escreveram sobre os problemas odontológicos no trabalho, afirmando que os problemas odontológicos são a terceira causa de absenteísmo no trabalho.

Revisando o tema saúde bucal dos trabalhadores, Peres (1989) descreve os agravos a essa condição, e conclui que há evidências de que determinadas atividades profissionais trazem riscos à saúde bucal; que há poucos trabalhos que abordem a relação saúde bucal-trabalho; e que esse tema deve merecer maior atenção por parte dos programas que objetivam estudar a relação saúde-trabalho.

Waldron (1989) relata que, na Inglaterra, poucos dentistas fazem parte dos serviços ocupacionais. Tal situação decorre da falta de dentistas e 
do grande investimento que a montagem de consultório demanda. Entretanto, ressalta que a empresa economizaria horas de trabalho, pois é muito difícil marcar consultas fora do horário de trabalho e, naquele país, cada saída do funcionário equivale a meio dia de trabalho.

Prosseguindo sua linha de pesquisa voltada aos trabalhadores de indústrias de chocolate, Petersen (1989) implementou e avaliou um programa preventivo de saúde bucal em duas fábricas. Cento e doze empregados participaram do programa e, após dois anos de sua implantação, o autor constatou uma visível redução nos índices de placa, de sangramento gengival, de cálculo, além de atitudes de saúde positivas por parte dos sujeitos envolvidos, o que indica o sucesso da iniciativa.

Bryant (1989) descreve dois casos de disfunção e dor miofacial em violeiros, demonstrando que é necessário considerar, na formulação do plano de tratamento, a ocupação, o estilo de tocar a viola, a tensão e a própria limitação física de cada indivíduo.

Para destacar a importância de programas de promoção em saúde bucal nos ambientes de trabalho, Schou (1989) arrola os benefícios que estes trazem a todas as partes envolvidas: o empregador terá redução de custos com saúde, aumento da produtividade e redução de absenteísmo; a odontologia obterá o aumento da utilização de seus serviços; e o empregado terá maior facilidade de acesso aos serviços dentários. O autor também cita os elementos essenciais para o sucesso desse tipo de programa: ativo envolvimento do trabalhador; uso de auxiliares dentais; realização voluntária de bochechos diários; promoção de atividades preventivas; uso da mídia de 
massa; transmissão de instruções de higiene oral e profilaxia; e treinamento pára-profissional.

Rahde \& Salvi (1989) apresentam uma lista de substâncias químicas que, em intoxicações ocupacionais, apresentam sinais e sintomas no aparelho gastrointestinal. Os autores preconizam a adoção de uma cuidadosa anamnese, na qual a listagem de sinais e sintomas associados a agentes etiológicos pode facilitar o diagnóstico em casos incomuns.

Gupta (1990) afirma que a cavidade bucal, e principalmente os dentes, podem ser os portadores dos primeiros sinais de doenças profissionais decorrentes da exposição a substâncias de origem física, química e biológica. Também descreve as manifestações bucais que ocorrem mais freqüentemente, e destaca a importância da higiene oral e do exame oral, que deve estar inserido no serviço de saúde ocupacional.

Para avaliar a hipótese de que o açúcar transportado pelo ar em ambientes de trabalho pode provocar doenças dentais ocupacionais, Masalin et al. (1990) estudaram 298 trabalhadores de indústrias de biscoito, doces e pães na Finlândia. As medidas de concentração de açúcar e farinha no ambiente de trabalho estavam dentro dos limites aceitos, o que levou os autores a concluir que a hipótese lançada não se sustenta. Para eles, o consumo de produtos açucarados - especialmente durante o horário de serviço -, a freqüência com que são consumidos, e o comportamento do trabalhador com relação a saúde bucal poderiam explicar parcialmente os altos índices de problemas dentários nesse tipo de ocupação. 
Ballantine et al. (1990) examinaram clinicamente 493 trabalhadores de plataformas de óleo e de gás, divididos em dois grupos, e concluíram que um grande número desses trabalhadores necessitava de tratamento odontológico, que o certificado de saúde dental deveria ser realizado a cada exame médico periódico, e que os médicos devem receber treinamento para orientar os indivíduos quanto à higiene bucal.

Para Kitamura \& Ferreira Jr. (1991), há muitos agentes nãoocupacionais que podem provocar o câncer de origem ambiental. São eles o tabaco, o álcool, as deficiências ou os excessos alimentares e a exposição à radiação solar ultra-violeta, que pode originar o câncer de lábios. Concluem que é necessário um diagnóstico da situação atual do Brasil sobre o problema, atuação na prevenção primária, diagnóstico precoce, vigilância epidemiológica e melhoria da legislação a respeito.

Examinando 88 trabalhadores expostos a fumos ácidos, e 81 trabalhadores (grupo controle) - que não vivenciavam essa situação profissional -, em duas indústrias da Tanzânia, Tuominen et al. (1991) obtiveram os seguintes resultados: $63,2 \%$ dos que eram expostos ao ácido inorgânico, e 37,7\% dos indivíduos do grupo controle apresentaram perda de superfície do dente; e 50,0\% dos trabalhadores expostos a ácido orgânico, e $14,3 \%$ dos que integravam o grupo controle tiveram essa mesma manifestação. Esses resultados permitiram que os autores concluíssem que o trabalho com fumos ácidos está fortemente associado à perda de superfície dentária. 
Tuominen (1991) investigou 82 trabalhadores expostos ao ácido inorgânico e 88 trabalhadores controle. Encontrou 36,9\% dos expostos com bolsas periodontais, contra $30,9 \%$ do grupo controle; no que concerne à idade, essa manifestação aumentava com o avançar dos anos de forma mais acentuada - e com padrão estatisticamente significativo - nos expostos do que nos componentes do grupo controle. Para a autora, tal achado leva a crer que a exposição ocupacional a fumos ácidos aumenta a prevalência de bolsas periodontais.

Estudando 63 trabalhadores de uma indústria de baterias expostos a ácido sulfúrico, Petersen \& Gormsen (1991) encontraram 31\% de erosão e 92\% de atrição dentárias, sendo que a erosão apresentou maior incidência nos dentes anteriores e a atrição predominou nos dentes posteriores. Assim, sugerem que ambas as manifestações são causadas pela exposição a ácido sulfúrico e, portanto devem ser reconhecidas como doenças ocupacionais.

Avaliando as condições bucais de 76 trabalhadores expostos a fumos ácidos e 81 trabalhadores que não vivenciavam essa situação, Tuominen \& Tuominen (1991a) obtiveram os seguintes resultados: 20 $(12,7 \%)$ dos expostos apresentaram erosão, que afetava mais os dentes anteriores do que os posteriores; o aumento da idade, e a freqüência de ingestão de frutas ácidas aumentam a probabilidade de erosão dental.

Para estudar a influência da exposição ao pó de cimento e pedra sobre a manifestação de alterações bucais, Tuominen \& Tuominen (1991b) avaliaram 36 trabalhadores expostos e 62 trabalhadores controle. Encontraram $72,2 \%$ dos expostos com perda de superfície dental, contra 
$48,4 \%$ do grupo controle. No maxilar e na mandíbula, nos dentes anteriores e nos dentes posteriores, a perda de superfície dentária foi maior no grupo exposto. Esses resultados levaram os autores a sugerir que a perda de superfície dentária por exposição ocupacional a pó deve ser considerada risco ocupacional.

Shalhoub (1991) relata dois casos de acidentes do trabalho que atingiram a face em indústria da Arábia Saudita, e comenta que o trauma industrial varia de acordo com a ocupação, e que a Arábia Saudita deve continuar os estudos e recomendações para as indústrias atuarem na prevenção de acidentes e no atendimento emergencial necessário.

Para Wotman (1991), a odontologia ocupacional é uma área a ser desenvolvida pela odontologia de forma semelhante à adotada pela medicina, ou seja, como sub-especialidade da odontologia em saúde pública, e deve contemplar a abordagem de monitoramento, a detecção e o controle de poluentes que causem manifestações bucais através dos dentes e da saliva nos pacientes, nos dentistas.

Silveira \& Ladeira (1991) analisaram 55 prontuários médicos de trabalhadores com diagnóstico de saturnismo no ambulatório de doenças profissionais de HC-UFMG, estudaram o sexo, ocupação, tempo de exposição, sinais, sintomas exames laboratoriais e tratamento. Enfatizaram que dentro da amostra pesquisada, encontraram apenas um paciente com a orla de Burton demonstrando que nem sempre ela faz parte do quadro clínico. 
As vantagens da implantação de serviços odontológicos para a população trabalhadora são, para Pinto (1992), o controle o absenteísmo e depois a melhora da saúde do trabalhador, nessa ordem. O autor descreve as modalidades de prestação de serviços, preconizando o atendimento no local de trabalho, com pessoal auxiliar, e mais unidades odontológicas fixas ou moduladas transportáveis.

No livro Toxicologia da Boca, Rahde \& Salvi (1992) discutem a importância da toxicologia para o cirurgião-dentista, tanto no diagnóstico quanto no tratamento das alterações bucais de origem ocupacional ou não. Também destacam que os estudos toxicológicos podem auxiliar no desempenho de atividades periciais, trabalhistas e legais.

Avaliando um programa de cuidados dentais preventivos de uma indústria na Austrália, no qual era realizado o trabalho preventivo e os procedimentos do tratamento eram referenciados a dentistas particulares, Westerman (1993) conclui que o sucesso de programas de saúde bucal depende de sua aceitação pelo empregado, da efetividade dos procedimentos adotados e da utilização de serviços profissionais adequados. Tais programas são bem aceitos tanto pelo empregador quanto pelo empregado.

Westergaard et al. (1993) descrevem o caso de um trabalhador com perda de substância dentária nos dentes incisivos e caninos de mandíbula e maxila. A causa dessa manifestação foi uma enzima proteolítica à qual o paciente estava exposto no seu ambiente de trabalho. 
Em uma revisão de literatura que objetivava verificar como as condições de saúde bucal afetam a saúde sistêmica, a qualidade de vida e a produtividade econômica, Hollister \& Weintraub (1993). Quanto ao primeiro aspecto - saúde sistêmica -, observaram essa relação em pacientes com febre reumática e transplantes de órgãos imunocomprometidos. Com relação à qualidade de vida, postulam que os problemas bucais levam a escolhas alimentares restritas, à dor orofacial e a mudanças sociais e comportamentais. Sob ponto de vista econômico, apontam o tempo perdido de trabalho em 1991, que foi de 3 dias/100 pessoas empregadas ao ano, razão semelhante àquelas decorrentes de infecções agudas do ouvido, dores de cabeça etc.

Para Silva (1994), o cirurgião-dentista pode atuar em perícias odontolegais que envolvam acidentes do trabalho que atinjam a face e a boca e doenças profissionais com manifestações bucais.

Em capítulo dedicados às manifestações bucais que mais freqüentemente decorrem de intoxicações por chumbo, mercúrio, arsênio, bismuto, substâncias ácidas e alcalinas etc., Pueyo et al. (1994) postulam que o paciente tem o direito a impetrar ações de reparação econômica quando elas se originarem de atividade profissional.

Ferreira (1994) enfatizou na sua reportagem sobre a forma alternativa, encontrada por entidades patronais como o SESI e o SESC, de organização da assistência odontológica em que procuram dar aos trabalhadores da indústria e do comércio atendimento odontológico e ocupacional. 
Zimmers \& Gobetti (1994) descrevem os problemas do complexo estomatognático que mais comumente acometem os músicos, quais sejam: lesões de tecido mole, mobilidade dentária, maloclusões, problemas da articulação têmporo-mandibular e patologias endodônticas. E trazem-nos uma interessante conclusão: tanto os instrumentos musicais afetam o complexo orodentofacial quanto a odontologia afeta a habilidade de tocar os instrumentos musicais.

Em capítulo dedicado à odontologia ocupacional, no qual discutem aspectos ligados à saúde bucal e às atribuições do cirurgião-dentista do trabalho, Caetano \& Watanabe (1994) recomendam a rigorosa e adequada manutenção do prontuário odontológico, e mencionam, dentre as atribuições do profissional, as atividades "periciais" ou de auditoria.

Para Alves (1995), os trabalhadores que desenvolvem atividades hiperbáricas - mergulho, construção civil e medicina - estão sujeitos, dentre outras doenças, ao barotrauma dental, que decorre da presença de bolhas gasosas que não se comunicam com o exterior no interior da polpa dentária e/ou do tecido mole, originando pressão negativa e dor.

Para avaliar os custos de tratamentos e de atividades preventivas de problemas odontológicos, Dini \& Castellanos (1995) avaliaram uma refinaria de álcool e açúcar localizada em Araraquara (Brasil) que tinha um quadro de 528 empregados. Os autores utilizaram o Índice Comunitário de Necessidade de Tratamento Periodontal (CPITN) e concluíram que, com um CD contratado por 4 horas e uma técnica em higiene dental atuando durante 8 horas diárias, o custo do projeto seria cerca de $48 \%$ (US $\$ 9,028)$ menor do 
que com a manutenção de um CD 8 horas/dia para a realização dos procedimentos periodontais necessários.

Em reportagem veiculada pela revista da Associação Paulista de Cirurgiões-Dentistas (APCD), Ferreira (1995) ressalta o crescimento da oferta de benefícios odontológicos das empresas a seus funcionários por meio da terceirização a empresas de odontologia de grupo, da formação de cooperativas e da autogestão de sistemas de saúde.

Midorikawa \& Nagano (1995) abordam a importância da presença odontologia na saúde ocupacional abordando suas funções e algumas manifestações bucais de doenças profissionais, e definem a odontologia do trabalho como a "parte da odontologia que tem por objetivo prevenir, reabilitar e preservar a saúde do trabalhador dos problemas causados pelo ambiente de trabalho que aparecem na cavidade bucal”.

Partindo da coleta de informações das Secretarias Municipais de Saúde (SMS) e dos Escritórios Regionais de Saúde de São Paulo (ERSA), Botazzo et al. (1995) estudaram o acesso dos trabalhadores aos sistemas locais de saúde em São Paulo. Concluíram que os trabalhadores são atendidos em regimes de urgência/emergência, que a assistência é ofertada de modo irregular, e que a criança continua sendo prioridade para os serviços públicos.

Em 1995, Araujo et al. estudaram a saúde bucal em trabalhadores portadores de LER. Utilizaram dois grupos de 6 pessoas, para os quais desenvolveram adaptações nas escovas de dentes e na forma de 
higienização, alcançando bons resultados com a interação paciente equipe interdisciplinar.

Duffy (1996) estudou a incidência de faltas ao trabalho por problemas odontológicos na Shell, no período de 1988 a 1994. Percebeu um aumento da porcentagem de absenteísmo decorrente desses problemas em relação ao total de faltas, o que se constituía em um problema significativo para a empresa. Assim, conclui que a promoção de saúde bucal simultaneamente ao tratamento, a educação em saúde bucal - para que o empregado assuma a responsabilidade de manter a sua saúde bucal - e o custeio, pela empresa, de campanhas de promoção de saúde e de exames periódicos poderiam melhorar a situação.

Em 1996, Santino detalhou os aspectos da intoxicação por chumbo inorgânico desde as fontes, a toxicologia, controle ambiental, clínico, laboratorial e tratamento. Descreveu as doenças ocupacionais decorrentes da exposição ao chumbo inorgânico e seus compostos e destacou dentre as suas manifestações, a linha de Burton como mais um dado para auxiliar no diagnóstico da intoxicação profissional.

Câmara et al. (1996) estudaram os níveis de exposição ao pó de mercúrio e seus efeitos na população de Paconé, Mato Grosso devido ao mercúrio metálico proveniente das casas compradoras de ouro. Dentre vários parâmetros utilizados apenas o gosto metálico e irritação ocular apresentaram diferença estatisticamente significativa para maior no grupo de moradores do centro da cidade em relação ao grupo controle moradores da 
área agrícola, mas também foram citados como sinais na cavidade bucal: a inflamação oral, a sialorréia e o amolecimento dos dentes.

Em reportagem a sobre "a influência da dor de dente" Baroni (1996), por meio de pesquisas e entrevistas, ressalta a importância da odontologia do trabalho na prevenção de acidentes de trabalho e na diminuição do absenteísmo.

Aplicando métodos preventivos de terapia periodontal em 550 trabalhadores chineses de organizações industriais divididos em quatro grupos, com idades de 25 a 44 anos durante 16 meses, Lim \& Davies (1996) concluíram que todos tiveram uma significativa diminuição de sangramento gengival e de quantidade de placa bacteriana. Assim, no planejamento de programas de saúde comunitária para promoção da saúde periodontal, a educação em higiene bucal deve ter a mais alta prioridade.

Em 1996, o Serviço Social da Industria (SESI) realizou um estudo sobre a saúde bucal dos trabalhadores da construção civil em Brasília Distrito Federal -, procurando traçar o perfil epidemiológico desta população. Esse estudo indicou que cabe ao SESI propiciar cuidados odontológicos, se possível no local cedido pela empresa, e que os programas voltados à saúde bucal devem privilegiar não apenas o aspecto curativo mas, principalmente, o preventivo.

No Congresso Internacional Forense'96, Midorikawa et al. (1996) apresentaram uma palestra na qual discutem a área pericial de acidentes e de doenças profissionais. Esse trabalho abrange o desenvolvimento da doutrina judicial, a legislação trabalhista, os aspectos periciais e as 
manifestações bucais de doenças profissionais de interesse para o cirurgiãodentista que atua na área pericial.

Na obra Compêndio de Odontologia Legal, Silva (1997) transcreve as manifestações bucais de doenças profissionais e aborda a possibilidade de o cirurgião-dentista realizar perícias em foro trabalhista em casos de acidentes de trabalho e de doenças profissionais, além de poder atuar como auditor em empresas que mantenham serviços de assistência odontológica na forma de autogestão.

Carranza Jr. (1997) descreve a possibilidade de que contato profissional com metais nas indústrias provoquem manifestações bucais ou por causa de intoxicações ou por absorção sem evidência de toxicidade, e cita as intoxicações por bismuto, chumbo, mercúrio, arsênico, fósforo, cromo e benzeno.

Quando avaliou os hábitos de higiene bucal de empregados de 18 empresas do Rio Grande do Sul (Brasil) - numa amostra de 234 mulheres e 237 homens com idades entre 24 e 44 anos -, Abegg (1997) observou que estes eram adequados, mas que as pessoas de categoria sócio-econômica inferior deveriam melhorá-los.

Lima (1997) analisou comparativamente 1774 atestados odontológicos da prefeitura e do Instituto Nacional de Assistência Medica da Previdência Social (INAMPS) de São José dos Campos e concluiu que, para a faixa de 10 a 20 anos de idade, foi estatisticamente significativo o índice de absenteísmo do sexo masculino em relação às outras faixas etárias; a predominância de absenteísmo por problemas odontológicos deu-se no 
grupo de trabalhadores de funções burocráticas nas faixas de 20 a 30 anos, de 40 a 50 anos e de mais de 50 anos em relação aos trabalhadores de função não burocrática.

Em reportagem sobre qualidade de vida e odontologia Ferreira (1997) aborda, entre outros temas, a presença odontologia nas empresas, e reforça os benefícios que dela advêm, como diminuição do absenteísmo, melhor qualidade de vida do funcionário e abatimento do imposto de renda das empresas. E conta sobre o exame odontológico no processo de admissão à aeronáutica, no qual a ausência de dentes, a presença de cáries e outros problemas odontológicos podem eliminar o candidato.

$\mathrm{Na}$ Enciclopédia de Segurança e Saúde Ocupacional da OIT, Gobbato (1998) aborda a importância da cavidade bucal e dos dentes na saúde ocupacional, descrevendo as lesões bucais decorrentes agentes físicos, químicos, biológicos. O autor preconiza que os programas de prevenção devem: seguir os princípios da prevenção contra riscos ambientais; promover a educação dos trabalhadores; realizar exames odontológicos admissionais e periódicos; e prover diagnóstico e tratamento precoce de doenças bucais ou dentais de origem ocupacional ou não.

Em 1998, Araujo estudou a prevalência de manifestações bucais em trabalhadores de indústrias de galvanoplastia. A autora concluiu que as condições de trabalho afetavam a saúde bucal dos trabalhadores; que cabe à equipe de saúde bucal prevenir os efeitos das doenças profissionais e conscientizar o trabalhador sobre a importância da preservação da saúde 
bucal, realizar diagnósticos precoces e contribuir com a equipe de saúde e de segurança do trabalho.

Zavariz \& Nogueira (1998) escreveram sobre a doença ocupacional causada pelo mercúrio e seus compostos. Os autores ressaltam a importância de estudos voltados ao assunto realizados nos últimos anos, e postulam que a odontologia atue efetivamente sobre essa patologia. Alertam que a exposição crônica apresenta a tríade clássica composta por gengivite, eretismo psíquico e temor, além de poderem surgir alterações sensoriais com parestesia da extremidade distal, da língua e ao redor dos lábios, salivação excessiva, ulceração da mucosa oral, linha gengival com coloração acinzentada, gosto metálico, hipertrofia das glândulas salivares, disfagia, dor à mastigação, amolecimento e queda dos dentes. A intoxicação aguda, dentre outros sintomas, apresenta distúrbios digestivos com irritação da mucosa bucal e perda de dentes.

Dissertando sobre o exame admissional, Schüler Sobrinho (1998) enfatiza a necessidade de a avaliação odontológica ser realizada pelo cirurgião-dentista, que deve se limitar "à constatação do estado geral da cavidade bucal, dentes e gengiva".

Velasco et al. (1999) abordaram a importância do uso dos protetores bucais na prevenção de traumas dentários. E, apesar de lembrarem que os esportes de contato são as ocupações que mais acentuadamente levam a esse tipo de problema, citam também as atividades profissionais e os acidentes automobilísticos. 
Para Araujo \& Gonini Jr. (1999), os exames admissional e periódicos são ótimas fontes de informação, e devem ser adotados conhecimento de epidemiologia para definir "medidas de controle necessárias para a elaboração de um programa de saúde que seja ideal para o trabalhador".

Hassell (1999) descreveu manifestações bucais de intoxicação por metais pesados como o chumbo, mercúrio e bismuto, que ocorrem quando os sulfuretos de metais pesados estão presentes no organismo e enfatizou que nos Estados Unidos estas intoxicações têm diminuído significativamente devido a diminuição da exposição a estes metais em acidentes de trabalho e de produto que os contenha.

Analisando as atividades que o homem exerce em condições de pressão atmosférica aumentada, Vieira (1999) cita, como uma das patologias, o barotrauma dental.

No livro Diagnóstico Bucal, Boraks (1999) também cita as manifestações bucais provocadas pelas alterações de pigmentação da gengiva, decorrentes da exposição profissional a substâncias tóxicas, como o saturnismo, o hidrargismo e a argiria.

Kawamura et al. (1999) estudaram as condições de saúde bucal de 77845 empregados japoneses para identificar diferenças entre homens e mulheres. Analisaram 60 parâmetros e, em 18 deles as mulheres reportaram um comportamento mais saudável que os homens - com diferença estatisticamente significativa. Assim, concluíram que o gênero e a idade são importantes para o planejamento de programas de educação em saúde dental, ou outros programas educacionais, no ambiente de trabalho. 
Para Pinto (2000), o serviço odontológico deve estar presente na empresa. E, quando de seu planejamento, devem ser priorizados os que recebem salários mais baixos, possuem dentes, não têm acesso a tratamento odontológico e apresentam má higiene bucal. Sugere ainda que os tratamentos preventivo e curativo sejam realizados preferencialmente na empresa, com consultório modular e equipe auxiliar.

Investigando a incidência de traumatismos dentais em dentes permanentes em Bragança Paulista, Ferrari et al. (2000) analisaram 189 casos - 355 dentes atingidos - no período de 1996 a 1999. Os autores comentam que os traumatismos dentais causam problemas estéticos, psicológicos e sociais. Acidentes automobilísticos e traumatismos na prática esportiva foram algumas das causas mais freqüentemente associadas a esses eventos. Assim, preconizam que a prevenção deve ser estimulada, o diagnóstico deve ser realizado com minúcia e sugerem a realização de novos estudos sobre o assunto.

Ferrari et al. (2000) realizaram um estudo sobre traumatismos dentários em 510 esportistas profissionais e semi-profissionais, e encontraram uma relação entre o menor índice de traumas dentais (11,5\%) observado em atletas de hóquei - e a utilização de protetor bucal (92,3\%); já entre os praticantes de jiu-jitsu, $41,1 \%$ relataram traumas dentais, e apenas $19,6 \%$ usavam protetor bucal. Assim, os autores enfatizam a necessidade de realização de campanhas para conscientizar os profissionais sobre a prevenção desses traumas. 
Martorelli et al. (2000) relatam um caso de traumatismo facial por acidente de trabalho em Recife. Um eletricista de automóveis, consertando um motor de partida de caminhão, acabou sendo atingido por um parafuso na região geniana esquerda; o objeto alojou-se no processo pterigóide direito do esfenóide. Os autores comentam que o Código de Trânsito Brasileiro diminuiu a incidência de traumas faciais por acidentes automobilísticos, propõem a promoção de campanhas preventivas sobre os acidentes de trabalho, nas empresas e nas escolas, para diminuir os traumas faciais. 


\section{PROPOSIÇÃO}

O objetivo desta dissertação é mostrar a importância da presença do cirurgião-dentista na equipe de Saúde do Trabalhador, tanto nas empresas públicas quanto nas particulares. Além disso também pretendemos, através da literatura especializada em diversas áreas do conhecimento, definir o campo de atuação e as funções deste profissional como especialista em Odontologia em Saúde do Trabalhador, e mostrar algumas informações sobre o tema, colhidas em empresas do Estado de São Paulo. 


\section{MATERIAL E MÉTODOS}

Nesta dissertação adotamos os métodos histórico, comparativo e monográfico. A análise pelo método histórico consistiu em investigar acontecimentos, processos e instituições em que a odontologia e sua relação com o trabalho estiveram presentes.

A utilização do método comparativo teve como objetivo confrontar as diferentes visões sobre a importância da odontologia na indústria, o conceito dos trabalhadores e empresários sobre o assunto e a analisar a atuação das outras profissões que compõem a equipe de saúde do trabalhador, tanto no passado quanto no presente.

Com o método monográfico estudamos o conjunto de atividades de um grupo de empresas na área de odontologia do trabalho, a fim de podermos obter generalizações acerca da atuação e atribuição do cirurgiãodentista à luz da filosofia da Saúde do Trabalhador (Lakatos \& Marconi, 1991; Cervo \& Bervian, 1996; Gil, 1999).

A Odontologia em Saúde do Trabalhador, apesar da sua importância dentro do contexto da Saúde do Trabalhador, ainda não é uma área de especialidade reconhecida. Por isso, através de uma pesquisa aplicada, procuramos determinar a importância do cirurgião-dentista do trabalho 
especialista em Odontologia em Saúde do Trabalhador e suas funções na equipe de saúde do trabalhador, tanto no âmbito público quanto no âmbito privado.

Foram levantados dados primários (pesquisa documental) como estatísticas, documentos oficiais, legislação, arquivos particulares, além de dados secundários (pesquisa bibliográfica) de jornais, revistas, livros, teses e outros documentos.

Como afirma Manzo (apud Marconi \& Lakatos, 1999), o levantamento bibliográfico promove "meios para definir, resolver, não somente problemas já conhecidos, como também explorar novas áreas onde os problemas não se cristalizaram suficientemente", e não se constitui em mera repetição do que já foi escrito: serve para a formação de um novo ponto de vista ou abordagem, levando a novas conclusões.

Desta forma, e considerando que o tema eleito - especificamente voltado à Odontologia em Saúde do Trabalhador - contempla poucos trabalhos publicados, o levantamento bibliográfico realizado foi amplo, abrangendo publicações de 1917 a 2000 das seguintes áreas: Saúde Ocupacional, Saúde do Trabalhador, Medicina do Trabalho, Ergonomia, Administração de Recursos Humanos, Administração de Serviços de Saúde, Medicina Legal, Odontologia Legal, Ética Médica, Deontologia Odontológica, Direito do Trabalho e Odontologia em Saúde Coletiva para compactar, em um sólido subsídio teórico, a importância da Odontologia em Saúde do Trabalhador e as funções do Cirurgião-Dentista do Trabalho. A busca deu-se em vários sistemas: MEDLINE, DEDALUS, BBO, mas muitos trabalhos 
foram encontrados quando da procura manual nas revistas especializadas, em um verdadeiro processo de "garimpagem", em bibliotecas de Unidades da Universidade de São Paulo, como aquelas das Faculdades de Odontologia, Medicina, Saúde Pública, Administração, Direito, Insituto de Psicologia e Escola Politécnica.

Na pesquisa de campo, utilizamos uma amostra não-probabilística intencional, pois estávamos interessados na opinião de médicos do trabalho ou gerentes do Serviço Especializado em Engenharia de Segurança e em Medicina do Trabalho (SESMT) ou de cirurgiões-dentistas que trabalhassem nas empresas contatadas.

Foram selecionadas, dentre as empresas cadastradas no CIESP, aquelas com mais de 1.000 empregados. Isto porque, de acordo com a Lei no 6.514, de 22 de dezembro de 1977, que contém as Normas Regulamentadoras aprovadas pela Portaria oㅜ 3.214, de 08 de junho de 1978, a NR-04 - que trata do dimensionamento do SESMT - obriga as empresas que tenham mais de 1.000 funcionários a possuírem, em seu quadro de funcionários, um médico do trabalho (Anexo 4). O levantamento acusou 268 empresas com cadastro no CIESP. Foram selecionadas as empresas que se localizavam no estado de São Paulo - 249 - e, destas, foram escolhidas aleatoriamente 75 empresas.

A carta era composta por envelope timbrado da Faculdade de Odontologia da Universidade de São Paulo (FOUSP), carta de apresentação, quatro questionários e envelope selado de resposta. A carta 
de apresentação e o questionário foram impressos em gráfica com papel especial de maior gramatura com o timbre da FOUSP (Anexo 5).

A carta de apresentação, endereçada ao departamento de Recursos Humanos $(\mathrm{RH})$ da empresa, impressa em papel timbrado da Faculdade de Odontologia da Universidade de São Paulo, explicava o tema da pesquisa, enfatizando o sigilo das respostas, o compromisso de retorno dos resultados e solicitando, ao Departamento de $\mathrm{RH}$, que repassasse os questionários para outros profissionais, como o médico do trabalho, o engenheiro de segurança do trabalho e o cirurgião-dentista, se houvesse. Solicitamos que nos enviassem as respostas pelo correio, no envelope pré-selado, em 30 dias. Os dados obtidos dos questionários estão apresentados sob a forma de gráficos.

$\mathrm{Na}$ pesquisa de campo exploratória, o objetivo do envio de um questionário (Anexo 5) com perguntas abertas e fechadas sobre odontologia em saúde do trabalhador foi aumentar a familiaridade do autor com o ambiente de Saúde do Trabalhador nas empresas, buscando maiores informações. Isto nos permitiu uma visão geral para a implementação de pesquisas futuras mais precisas sobre 0 assunto. 


\section{RESULTADOS}

Apenas oito empresas responderam aos questionários, e os resultados foram dispostos da seguinte forma:

- Critério de seleção das empresas

- Descrição das opiniões obtidas nos questionários, por empresa

- Descrição dos gráficos obtidos através dos questionários

O estudo de casos contemplou empresas de grande porte, de acordo com o critério adotado pelo Cadastro Industrial do Centro das Industrias do Estado de São Paulo (CIESP), que o estruturou por número de empregados:

\begin{tabular}{|lrrr|c|}
\hline \multicolumn{3}{|c|}{ No DE EMPREGADOS } & CLASSIFICAÇÃO DA CIESP \\
\hline $\mathrm{De}$ & 0 & $\mathrm{a}$ & 9 & MI - Micro empresa \\
\hline $\mathrm{De}$ & 10 & a & 99 & PE - Pequena empresa \\
\hline $\mathrm{De}$ & 100 & a & 499 & ME - Média empresa \\
\hline $\mathrm{De}$ & 500 & e & mais & GR - Grande empresa \\
\hline
\end{tabular}

A seguir apresentamos, de forma resumida, os resultados obtidos com os questionários que as empresas consultadas na pesquisa devolveram. 


\section{Empresa 01:}

Quem respondeu ao questionário: Médico do Trabalho

Conta com 1122 funcionários.

Possui Serviço Especializado em Segurança e Medicina do Trabalho com a seguinte composição:

- 01 Médico do Trabalho,

- 01 Auxiliar de Enfermagem do Trabalho,

- 01 Engenheiro de Segurança do Trabalho,

- 04 Técnicos de Segurança do Trabalho, e,

○ 04 Auxiliares de Enfermagem.

\section{Opiniões:}

- Acha importante a saúde bucal para o bom desempenho dos funcionários, e acredita que a empresa deve facilitar o acesso ao tratamento odontológico. A empresa possui um serviço odontológico terceirizado, que realiza atividades de odontologia preventiva e curativa. A saúde bucal dos funcionários é boa.

- Define a Odontologia da Trabalho como a parte da odontologia que estuda as repercussões odontológicas das doenças do trabalho (sic).

- As funções que o CD do Trabalho poderia desempenhar dentro da Equipe de Saúde do Trabalhador são: odontologia preventiva, odontologia curativa e identificação de patologias odontológicas ligadas ao trabalho. 


\section{Empresa 01 - A:}

Quem respondeu ao questionário: Cirurgiã-Dentista

Opiniões:

- Acha importante a saúde bucal para o bom desempenho dos funcionários, e acredita que a empresa deve facilitar 0 acesso ao tratamento odontológico. A empresa possui um serviço odontológico terceirizado, que realiza atividades de de clínica geral (restaurações, exodontias simples, profilaxia, prevenção, emergência em geral etc.) (sic). A saúde bucal dos funcionários é boa.

- Não apresentou definição sobre Odontologia do Trabalho. Acha que não existe essa especialidade na odontologia (sic). As funções que o CD do Trabalho poderia desempenhar dentro da Equipe de Saúde do Trabalhador são: restabelecer a saúde, a função e a estética, além de conscientizar o trabalhador sobre a importância da prevenção, diminuindo assim os índices de absenteísmo (sic).

\section{Empresa 01 - B:}

Quem respondeu ao questionário: Cirurgião-Dentista

Opiniões:

- Acha importante a saúde bucal para o bom desempenho dos funcionários, e acredita que a empresa deve facilitar 0 acesso ao tratamento odontológico. A empresa possui um serviço odontológico terceirizado, que realiza atividades de clínica geral (restaurações, profilaxia, prevenção, exodontias simples, emergência etc.) (sic). A saúde bucal dos funcionários é boa. 
- Não apresentou definição sobre Odontologia do Trabalho. Acha que não existe essa especialidade na odontologia (sic) As funções que o CD do Trabalho poderia desempenhar dentro da Equipe de Saúde do Trabalhador são: convocar os funcionários para um controle mais rigoroso de sua saúde bucal, por meio de exames periódicos, com o objetivo de conscientizá-los sobre seus problemas e a prevenção contra possíveis doenças bucais (sic).

\section{Empresa 02:}

Quem respondeu ao questionário: Analista de Pessoal

Conta com 820 funcionários.

> Possui Serviço Especializado em Segurança e Medicina do Trabalho com a seguinte composição:

- 01 Médico do Trabalho,

- 01 Engenheiro de Segurança do trabalho,

- $\quad 03$ Técnicos de Segurança do Trabalho.

\section{Opiniões:}

- Acha importante a saúde bucal para o bom desempenho dos funcionários, e acredita que a empresa deve facilitar o acesso ao tratamento odontológico. A empresa possui um serviço odontológico terceirizado que realiza atividades de odontologia preventiva e curativa. A saúde bucal dos funcionários é ruim.

- Não vê diferença entre a odontologia do trabalho e a odontologia. As funções que $\mathrm{C} C D$ do Trabalho poderia desempenhar são: odontologia preventiva com campanhas e palestras preventivas. 


\section{Empresa 03:}

Quem respondeu ao questionário: Gerente de Medicina do Trabalho

Conta com 900 funcionários.

Possui Serviço Especializado em Segurança e Medicina do Trabalho com a seguinte composição:

- 02 Médicos do Trabalho,

- 05 auxiliares de enfermagem do trabalho,

- 01 Engenheiro de Segurança do trabalho,

- 06 Técnicos de Segurança do Trabalho,

- 04 auxiliares de segurança do trabalho, e,

○ 01 assistente social.

Opiniões:

- Acha importante a saúde bucal para o bom desempenho dos funcionários, e acredita que a empresa deve facilitar o acesso ao tratamento odontológico. A empresa possui dois serviços odontológicos: um pertencendo aos funcionários, que realiza atividades de odontologia básica, e outro de empresas do setor, que realiza atividades de odontologia preventiva e curativa, incluindo prótese. A saúde bucal dos funcionários é ruim.

- Define a Odontologia do Trabalho como aquela que proporciona a melhoria da saúde bucal dos funcionários, visando a prevenção de doenças odontológicas (sic). As funções que o CD do Trabalho poderia desempenhar dentro da equipe de Saúde do Trabalhador são: ações preventivas voltadas ao perfil odontológico da empresa, palestras educativas e ações corretivas (sic). 


\section{Empresa 04:}

Quem respondeu ao questionário: Gerente de Sistema de Saúde e Proteção

> Conta com 1500 funcionários.

> Possui Serviço Especializado em Segurança e Medicina do Trabalho com a seguinte composição:

- 02 Médicos do Trabalho,

- 01 auxiliar de enfermagem do trabalho,

- 01 Engenheiro de Segurança do trabalho,

- $\quad 03$ Técnicos de Segurança do Trabalho.

\section{Opiniões:}

- Acha importante a saúde bucal para o bom desempenho dos funcionários, e acredita que a empresa deve facilitar 0 acesso ao tratamento odontológico. A empresa possui um serviço odontológico terceirizado através da cooperativa de funcionários, que desempenha atividades de odontologia assistencial, primordialmente, aos funcionários e seus dependentes no consultório interno da empresa, e na rede própria e credenciada (sic). A saúde bucal dos funcionários é boa.

- Define a Odontologia da Trabalho como sendo uma atividade direcionada ao trabalhador, com foco nas suas atividades laborativas e no seu "habitat", e, sobretudo, com características prevencionistas (sic). As funções que o CD do Trabalho poderia desempenhar dentro da equipe de Saúde do trabalhador são: complementação dos exames médicos ocupacional, préadmissional, periódicos ou demissional, com um "retrato" da saúde bucal; ministração de palestra e distribuição de material 
educativo e outros veículos que incentivem os funcionários e a comunidade empresarial (dependentes) a praticar hábitos que promovam a saúde bucal, deixando de priorizar, como é comum, a odontologia assistencial, curativa (sic).

- Parabeniza a iniciativa e a idéia de abordar um assunto tão importante e inexplorado no meio da saúde do trabalhador.

\section{Empresa 05:}

Quem respondeu ao questionário: Líder do Núcleo de Benefícios e Segurança do Trabalho

Conta com 969 funcionários.

Possui Serviço Especializado em Segurança e Medicina do Trabalho parcialmente terceirizado com a seguinte composição:

- 02 Médicos do Trabalho terceirizado,

- 02 auxiliares de enfermagem do trabalho,

- 01 Técnicos de Segurança do Trabalho, e relata,

- 12 membros da CIPA.

\section{Opiniões:}

- Acha importante a saúde bucal para o bom desempenho dos funcionários, e acredita que a empresa deve facilitar o acesso ao tratamento odontológico. A empresa possui um serviço odontológico terceirizado de autogestão do setor, que realiza atividades de cobertura total, excetuando ortodontia a dependentes com idade superior a 14 anos e implante. A saúde bucal dos funcionários é boa.

- Não apresentou definição sobre Odontologia do Trabalho. Acredita que esta atividade apenas integra o plano de benefícios 
estabelecidos pela companhia (sic). As funções que o CD do Trabalho poderia desempenhar dentro da equipe de Saúde do trabalhador são: além da habitual, a preventiva (sic).

- Como observação, ressalta a importância de que todos os convênios médicos contemplem o serviço odontológico.

\section{Empresa 06:}

> Quem respondeu ao questionário: Médico do Trabalho

> Conta com 1700 funcionários.

> Possui Serviço Especializado em Segurança e Medicina do Trabalho com a seguinte composição:

- 02 Médicos do Trabalho,

- 01 enfermeira do trabalho,

- 02 auxiliares de enfermagem do trabalho,

- 01 Engenheiro de Segurança do trabalho,

- 05 Técnicos de Segurança do Trabalho, e,

○ 02 auxiliares de enfermagem.

\section{Opiniões:}

- Acha importante a saúde bucal para o bom desempenho dos funcionários, e acredita que a empresa deve facilitar o acesso ao tratamento odontológico. A empresa possui um serviço odontológico terceirizado através de rede credenciada diretamente pela empresa, que realiza atividades como consultas, perícia, exames complementares, dentística, endodontia, exodontias e raspagem supragengival. A saúde bucal dos funcionários é boa. 
- Define a Odontologia da Trabalho com sendo um campo específico da área da odontologia que procura atuar na promoção e proteção da saúde bucal das pessoas envolvidas no trabalho (sic). As funções que $\mathrm{O} C D$ do Trabalho poderia desempenhar dentro da Equipe de Saúde do Trabalhador são: exames odontológicos admissional e periódicos, programas de educação preventiva, atendimento de urgências odontológicas no trabalho

\section{Empresa 07':}

> Quem respondeu ao questionário: Assistente Social

Conta com 200 funcionários.

$>$ Possui Serviço Especializado em Segurança e Medicina do Trabalho com a seguinte composição:

○ 01 Médico do Trabalho,

○ 01 auxiliar de enfermagem do trabalho,

○ 01 Engenheiro de Segurança do trabalho.

\section{Opiniões:}

- Acha importante a saúde bucal para o bom desempenho dos funcionários, mas acredita que não é responsabilidade da empresa facilitar o acesso ao tratamento odontológico. A empresa não possui nenhum tipo de serviço odontológico, desta forma não sabe como é a saúde bucal dos funcionários.

○ Não apresentou definição sobre Odontologia do Trabalho. As atividades que o CD do Trabalho poderia desempenhar dentro da Equipe de Saúde do Trabalhador são: trabalho preventivo,

1 Obs. Esta empresa constava no Cadastro Industrial da CIESP como de grande porte. 
por meio da educação em saúde bucal, trabalho este que deveria ser extensivo à família dos colaboradores, principalmente aos seus filhos (através de pinturas educativas, sendo a mais bonita premiada com fio dental, por exemplo) (sic). Também acha que a empresa poderia dispor de espaço para um consultório odontológico que atuasse de forma corretiva o que, além de reduzir o absenteísmo, poderia contribuir para a melhoraria da qualidade de vida do colaborador e, conseqüentemente, reduziria os custos.

\section{Empresa 08:}

Quem respondeu ao questionário: Médico do Trabalho

Conta com 1700 funcionários.

Possui Serviço Especializado em Segurança e Medicina do Trabalho com a seguinte composição:

- 02 Médicos do Trabalho,

- 02 auxiliares de enfermagem do trabalho,

- 01 Engenheiro de Segurança do trabalho,

- 04 Técnicos de Segurança do Trabalho, e,

○ 04 auxiliares de enfermagem.

$>$ Opiniões:

- Acha importante a saúde bucal para o bom desempenho dos funcionários, e acredita que a empresa deve facilitar o acesso ao tratamento odontológico. A empresa possui um serviço odontológico próprio, que realiza atividades de odontologia preventiva e clínica geral para funcionários e dependentes. A saúde bucal dos funcionários é boa. 
- Define a Odontologia da Trabalho com uma especialidade de prevenção à saúde (sic). As funções que o CD do Trabalho poderia desempenhar dentro da Equipe de Saúde do Trabalhador são: participação em processos educacionais, assistência odontológica preventiva, profilaxia, aplicação de flúor, aplicação de selante etc, além de assistência odontológica curativa.

Os questionários foram analisados, e os resultados estão apresentados, sob a forma de gráficos, nas Figuras 4 a 9:

$\mathrm{Na}$ Figura 4 podemos observar que todas as empresas que responderam ao questionário mantém o SESMT, com composição variada de acordo com a legislação, e que apenas uma empresa mantém nessa equipe um profissional que não consta da legislação, qual seja, uma assistente social.

A Figura 5 mostra a distribuição de profissionais que compõem o SESMT das empresas que responderam ao questionário. Observa-se uma distribuição normal, com prevalência de técnicos de segurança do trabalho e enfermeiros do trabalho, seguidos por médicos e engenheiros de segurança.

Na Figura 6 observamos que a maior parte das empresas acha importante a saúde bucal para o desempenho dos funcionários, e acredita que a empresa deve facilitar o acesso ao tratamento odontológico. Apenas uma empresa acha a saúde bucal importante, mas acredita que não é responsabilidade da empresa facilitar o acesso ao tratamento odontológico.

A Figura 7 mostra apenas uma empresa não tem qualquer tipo de assistência odontológica aos funcionários. As formas de assistência são: autogestão (4) e odontologia de grupo (3), conforme mostra a Figura 8 . A 
maioria das empresas considera boa a condição de saúde bucal dos trabalhadores; uma empresa não tem essa informação; e duas acreditam que a condição de saúde bucal dos trabalhadores é ruim (Figura 9).

Com relação às respostas de opinião, percebemos que a maioria (6) das empresas não definiu a Odontologia em Saúde do Trabalhador, e que apenas duas empresas ( 1 e 4 ) relacionaram a atuação do CD com o trabalho.

Quanto às funções que $O C D$ pode desempenhar na equipe, percebemos que ainda é predominante a visão assistencial, e que apenas três empresas citaram funções diferentes daquelas da odontologia assistencial (1, 4 e 6$)$. É interessante ressaltar que os dois CDs que responderam ao questionário não definiram a Odontologia em Saúde do Trabalhador, e que sua visão sobre o assunto ainda está muito ligada ao assistencialismo. 


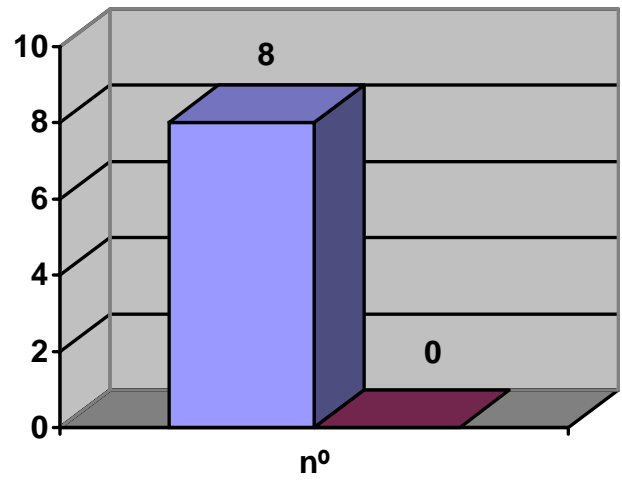

$\square \operatorname{Sim}$
$\square$ Não

Figura 4 - Empresas que possuem Serviço Especializado em Segurança e Medicina do Trabalho.

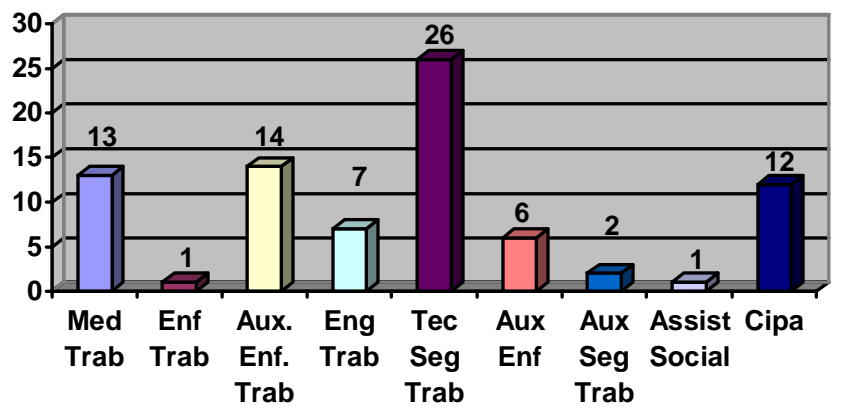

\begin{tabular}{|l|}
\hline Med Trab \\
$\square$ Enf Trab \\
$\square$ Aux. Enf. Trab \\
$\square$ Eng Trab \\
$\square$ Tec Seg Trab \\
$\square$ Aux Enf \\
$\square$ Aux Seg Trab \\
$\square$ Assist Social \\
Cipa
\end{tabular}

Figura 5 - Profissionais que compõem as equipes do SESMT.

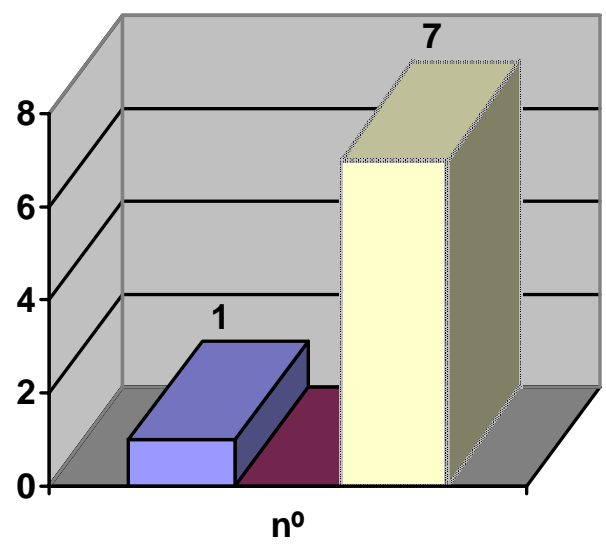
$\square E ́$ importante para o bom desempenho dos funcionários, mas não é responsabiliade da empresa

$\square$ Não faz diferença para o bom desempenho dos funcionários

$\square$ É importante para o bom desempenho dos funcionários e a empresa deve facilitar o acesso do trabalhador ao tratamento odontológico

Figura 6 - Opiniões sobre a saúde bucal. 


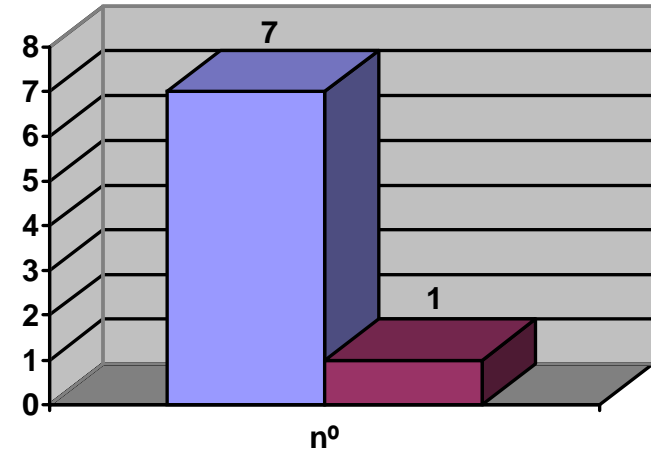

$\square \operatorname{Sim}$

पNão

Figura 7- Existência de serviço odontológico na empresa.

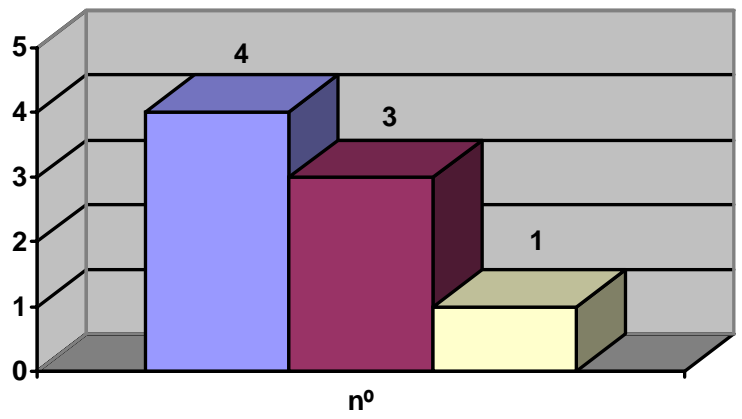

$\square$ Auto-gestão

$\square$ Odontologia de grupo

$\square$ Não tem

Figura 8 - Modalidades de serviço odontológico da empresa.

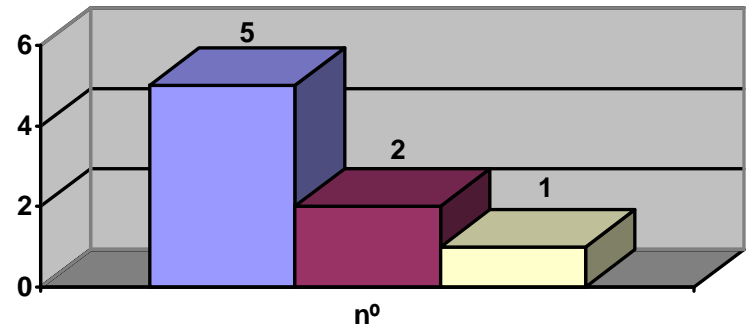

$\square$ Boa

$\square$ Ruim

$\square$ Não sabe

Figura 9 - Opiniões sobre a condição de saúde bucal dos funcionários. 


\section{DISCUSSÃO}

Neste capítulo abordaremos, com maior profundidade, a globalização e a qualidade de vida no trabalho e sua repercussão na empresa e no trabalhador. Em seguida discutiremos o papel da odontologia na indústria sob o ponto de vista histórico, e o panorama atual da Saúde Bucal no Brasil. Também comentaremos a importância da saúde bucal e a evolução e a interferência de algumas doenças bucais sobre o trabalho, além dos dados registrados pela literatura com relação ao absenteísmo decorrente de problemas odontológicos.

Daí por diante, partiremos para a delimitação do campo de atuação da odontologia em Saúde do Trabalhador: definição, objetivos, benefícios, política de saúde na empresa e política de odontologia em Saúde do Trabalhador, e funções do CD do Trabalho.

\subsection{GLOBALIZAÇÃO E QUALIDADE DE VIDA NO TRABALHO - REPERCUSSÕES PARA A EMPRESA E PARA O TRABALHADOR}

Contador (1997) relata que, em 1980, "uma nova realidade de mercado impôs uma intensificação sem precedente do aumento da produtividade industrial e 
a conseqüente intensificação, também sem precedente, do desemprego, que assola todos os países industrializados”.

No processo de globalização da economia, "as grandes empresas industriais, com o instinto da sobrevivência suplantando o objetivo do lucro, forçaram, por intermédio da diplomacia de seus governos nos organismos internacionais, a abertura comercial nos países emergentes e o afrouxamento das barreiras alfandegárias nos países industrializados, e passam a operar global e agressivamente" (Contador, 1997).

A reação ocidental contra a perda de mercado para as indústrias japonesas, iniciada na década de 50, só ocorreu nos primeiros anos da década de 80 , por meio de programas voltados ao aumento de produtividade, à qualidade e à redução de custos.

Programas gerenciais - chamados programas de qualidade e baseados nas técnicas japonesas - foram implantados nas empresas com a aquisição de máquinas e equipamentos modernos. Isso provocou o aumento da produtividade, mas não ao incremento da produção industrial, provocando demissões em massa e aumento do desemprego.

As mudanças sócio-econômicas que ora ocorrem no mundo, como não poderia deixar, repercutem no Brasil. Em 1998, dez milhões de pessoas perderam o emprego no mundo, e um bilhão de trabalhadores estavam desempregados, sem contar o grande número de pessoas em subempregos ou trabalhando em tempo parcial e recebendo salários inferiores. Em nosso país, a economia informal cresceu cerca de 46\% de 1989 a 1997 e, em 1999 - segundo dados do Instituto Brasileiro de Geografia e Estatística (IBGE) - a 
informalidade chegou a 46,6\% (Escóssia \& Clemente, 2000). Deve-se ressaltar que as ações do governo, dos sindicatos e das empresas para o desenvolvimento de políticas de emprego são necessárias para a superação desta nova situação de trabalho (Silva, 1999).

Silva (1999) comenta que a Globalização da economia "exerceu um impacto extremamente positivo na troca de informações. Descobertas científicas, pesquisas e bancos de dados tornaram-se acessíveis a todos, bastando ter uma máquina - o computador - acoplada a uma linha telefônica".

A eliminação de postos de trabalho e a competitividade dos produtos importados obrigaram as empresas a se adequarem e a abrirem novos caminhos, buscando a melhoria da qualidade e da produtividade, a diminuição dos custos e a otimização dos recursos da empresa, aí contemplados os recursos humanos e os recursos materiais (Dias, 2000).

Para Bouer (1997), o termo Qualidade Total foi consagrado pelo uso, mas recentemente o termo "Total Quality Management (TQM) tem sido utilizado para transmitir a mensagem básica de um sistema de qualidade voltado para resultados, cobrindo a organização como um todo e a todos que compõem a organização".

Os programas de Qualidade Total tornaram-se conhecidos através de Deming, especialista que, em 1946, foi enviado para auxiliar na reindustrialização do Japão e que difundiu o controle estatístico da qualidade (CEQ). Deming também enfatizou o comprometimento e as ações da gerência das empresas, postulando que seu sistema fosse adotado em todos os escalões (Green, 1995; Bouer, 1997). 
Para Deming (1990), a melhor qualidade levaria a uma diminuição do custo, graças aos menores índices de re-trabalho, de erros, de atrasos e de obstáculos, e ao melhor uso do tempo, das máquinas e dos insumos. Como conseqüência, haveria aumento da produtividade e captação de mercados com melhor qualidade e preços menores, o que levaria à manutenção dos negócios e à ampliação do mercado de trabalho.

Juran, famoso consultor em qualidade norte-americano, conhecido por difundir o controle total da qualidade (TQC), foi convidado pela União Japonesa de Cientistas e Engenheiros (JUSE) para visitar o Japão em 1954. Detentor de conhecimentos que abrangiam os mecanismos gerenciais de planejamento, organização e controle, esse profissional enfatizou a necessidade de medir os resultados e aplicar uma metodologia para a solução de problemas, além de promover melhorias significativas em padrões de resultados (Green, 1995; Bouer, 1997).

Green (1995) e Bouer (1997) relatam que Philip Crosby, também famoso consultor de qualidade e liderança norte-americano, preconizava um sistema de alcance de melhores padrões de qualidade baseado na prevenção, e que estabeleceu o "zero defeitos". Ele destacou a motivação e o planejamento, trabalhou a idéia de que "qualidade é investimento", "qualidade é de graça", e que qualquer custo destinado à melhoria da qualidade é recompensado pela economia de matéria-prima e de mão-deobra consumidas na correção dos defeitos.

Kaoru Ishikawa foi o pioneiro japonês da qualidade. Enfatizava que a prática da qualidade deveria ocorrer o tempo todo, de modo sistemático e 
sem interrupções. Sempre aconselhando que o "processo subseqüente é o seu cliente" desenvolveu, em 1962, os círculos de controle da qualidade (CCQ) (Green, 1995; Bouer, 1997).

A aplicação desses programas de qualidade nas empresas ocidentais, entre 1975 e 1985, caracterizou-se por enfatizar a filosofia da qualidade e as técnicas estatísticas. Entretanto, são hoje considerados a primeira geração dos programas de qualidade, pois muitos casos de insucesso foram aparecendo, e a análise dos resultados indicou que necessitavam ser continuamente revitalizados, pois não apresentavam um efetivo aumento no lucro e na qualidade dos produtos. Finalmente acabaram sendo taxados de ineficazes.

A segunda geração de programas de qualidade caracteriza-se pela liderança do corpo diretivo da empresa, pela ênfase na cultura do market-in, pelo plano de qualidade vinculado aos planos estratégicos e de gestão, pelos resultados expressivos alcançados no curto prazo e pela integração entre o fornecedor-cliente interno e os fornecedores-clientes externos. Os resultados obtidos são relatados por Bouer (1997), que lembra que " $a$ qualidade tem atingido a curto prazo as metas estabelecidas e o programa passa a ser um sistema de gerenciamento da organização".

Para Fernandes (1996), "não se pode falar em qualidade de produtos e serviços se aqueles que vão produzi-los não tem qualidade de vida no trabalho" e, em decorrência da competição cada vez maior imposta pela concorrência, é necessário desenvolver uma forma de gerenciamento mais eficiente dos recursos humanos ou trabalhadores da empresa. 
O que temos visto ainda são altos índices de acidentes de trabalho, o surgimento de novas doenças profissionais - como as Lesões por Esforços Repetitivos (LER) ou Doenças Osteomusculares Relacionadas ao Trabalho (DORT) -, e o aumento dos índices de alcoolismo e de consumo de drogas. O setor empresarial já reconhece esses problemas, e tem procurado dar condições mais adequadas de trabalho aos trabalhadores, para que estes possam desenvolver seu potencial e sua criatividade, reduzindo as condições predisponentes à geração de estresse e à má qualidade de vida.

Rodrigues (1991) entende Qualidade de Vida no Trabalho (QVT) como "a resultante direta da combinação de diversas dimensões básicas da tarefa e de outras não dependentes diretamente da tarefa, capazes de produzir motivação e satisfação em diferentes níveis, além de resultar em diversos tipos de atividades e condutas dos indivíduos pertencentes a uma organização".

Para Fernandes (1996), a Qualidade de Vida no Trabalho é "a gestão dinâmica e contingencial de fatores físicos, tecnológicos e sócio-psicológicos que afetam a cultura e renovam o clima organizacional, refletindo-se no bem-estar do trabalhador e na produtividade das empresas".

Para a obtenção do bem-estar do trabalhador e o aumento da produtividade, Walton (apud Rodrigues, 1991; Fernandes, 1996), em 1975, propôs oito critérios de QVT que são, resumidamente:

1. Compensação justa e adequada - que visa mensurar a remuneração recebida através da remuneração adequada, da eqüidade interna e da eqüidade externa com relação aos colegas no mercado de trabalho;

2. Condições de segurança e saúde do trabalho - mede as condições de trabalho com critérios de jornada de trabalho, carga de trabalho, 
ambiente físico, material e equipamento, ambiente saudável com mínimo risco de doença, danos e estresse;

3. Oportunidade imediata para o uso e desenvolvimento da capacidade humana - mede a oportunidade de aplicar o seu saber e aptidões utilizando critérios de autonomia, significado da tarefa, identidade da tarefa, variedade da habilidade e retroinformação;

4. Oportunidade de crescimento e segurança - mede a oportunidade de desenvolvimento e de crescimento pessoal dos empregados através de critérios de possibilidade de carreira, crescimento pessoal e segurança de emprego;

5. Integração social na organização de trabalho - mede o grau de integração social que existe na empresa através de critérios de igualdade de oportunidades, relacionamento e senso comunitário;

6. Constitucionalismo na organização do trabalho - mede o grau de cumprimento da empresa com relação aos direitos dos empregados com os critérios de direitos trabalhistas, privacidade pessoal, liberdade de expressão e normas e rotinas;

7. Trabalho e espaço total de vida - mede o equilíbrio da vida pessoal e a vida no trabalho com critérios de papel balanceado no trabalho e horário de entrada e saída do trabalho;

8. Relevância social da vida no trabalho - mede a responsabilidade social da empresa na comunidade, a qualidade de prestação de serviços e atendimento aos empregados pelos critérios de imagem da organização, de responsabilidade social da instituição e de responsabilidade social pelos serviços e pelos empregados.

Werther Jr. \& Davis (1983) afirmam que a qualidade de vida no trabalho "é afetada por muitos fatores: supervisão, condições de trabalho, pagamento, benefícios e projeto do cargo. Porém, é a natureza do cargo que envolve mais intimamente o trabalhador". 
Para Fernandes (1996), os fatores-chave da QVT são:

- Condições de trabalho - que tem como indicadores o desempenho, a limpeza, a arrumação, a segurança e a insalubridade;

- Saúde - com os indicadores assistência (funcionário/família), educação/conscientização e saúde ocupacional;

- Moral - cujos indicadores são identidade na tarefa, relações interpessoais, reconhecimento/feedback, orientação para pessoas e garantia de emprego;

- Compensação - com os indicadores salários (eqüidade externa), salários (eqüidade interna), salário variável (bônus, participação etc), benefícios oferecidos pela empresa e benefícios em relação a outras empresas;

- Participação - que tem como critérios a criatividade/expressão pessoal, a repercussão das idéias propostas e os programas de participação/capacitação;

- Comunicação - cujos critérios são conhecimento das metas, fluxo de informação (top-down), fluxo de informação (mesmo nível) e veículos informais;

- Imagem da empresa - que tem como critérios a identificação da empresa, sua imagem interna, sua imagem externa, sua responsabilidade comunitária e o enfoque no cliente;

- Relações chefe/subordinado - com os critérios apoio sócio-emocional, orientação técnica, igualdade de tratamento e gerenciamento pelo exemplo; e,

- Organização do trabalho - cujos critérios são inovações/métodos/processos, grupos de trabalho, variedade e ritmo.

A QVT pode ser utilizada pela empresa para produzir o aumento do grau de satisfação dos trabalhadores, que promoverá o incremento da 
produtividade como resultado da maior participação do trabalhador nas decisões sobre os processos relacionados ao seu trabalho.

Os desafios apresentados às empresas neste novo milênio são a manutenção de uma força de trabalho (trabalhadores) saudável, motivada e preparada para a competição acirrada provocada pela globalização da economia, e sua capacidade de responder às exigências dos trabalhadores por uma melhor qualidade de vida.

Todas as formas de avaliação da qualidade de vida no trabalho colocam a saúde como um item importante, que não deve ser deixado de lado por nenhuma empresa.

Os programas de Qualidade de Vida e de promoção de saúde trazem os seguintes benefícios: melhor saúde e estilo de vida, melhor disposição geral, melhor educação nutricional e menores riscos cardíacos (Silva \& De Marchi, 1997). A saúde bucal não tem feito parte dos programas de saúde dos trabalhadores.

\subsection{A ODONTOLOGIA NA INDÚSTRIA E O PANORAMA DA ODONTOLOGIA E DA SAÚDE BUCAL NO BRASIL}

Os primeiros sistemas de cuidados quanto à saúde dental voltados aos trabalhadores foram implantados em 1887 - na Grande Estrada de Ferro 
Oeste da Inglaterra -, e em 1890 - pela Companhia Barber Match do Canadá (Ayer et al., 1986; Feaver, 1988).

Os primeiros consultórios odontológicos em empresas foram estabelecidos em empresas norte-americanas em 1915, a saber: Chicago Plant of Montgomery Ward \& Company - com cinco cadeiras clínicas - e Metropolitan Life Insurance Co. (Heacock, 1943; Dunning \& Klein, 1944; Thomas, 1944).

Em 1916, a Companhia de Motores Ford abriu seu primeiro hospital de emergência industrial, que possuía um completo departamento dental (MacKenzie, 1951). Na Itália, a Companhia Olivetti, em 1936, estabeleceu o serviço odontológico para seus trabalhadores.

Em 1920 Thaddeus P. Hyatt, diretor odontológico da Cia. de Seguro de Vida Metropolitana dos EUA, apresentou os objetivos da odontologia na indústria: educar os trabalhadores; realizar procedimentos preventivos (tratamento profilático, exames e radiografias, com os objetivos preventivo e educativo); encaminhar os casos que necessitem de tratamento a um dentista externo. Em 1923, havia 100 consultórios dentários empregando serviços de dentistas na indústria americana (Heacock, 1943).

Heacock (1943) conta que, em 1939, pesquisa do Comitê de Economia da ADA e do Comitê de odontologia Industrial do 1ํㅡㄹ Distrito da Sociedade Dental da Cidade de Nova lorque em cooperação com a Cia. de Seguro de Vida Metropolitana mostrou que 144 indústrias tinham algum tipo de programa odontológico. 
A odontologia em empresas nos EUA caracterizou-se, desde o início do século, como um serviço ocupacional com funções assistenciais. Na $2^{\mathrm{a}}$ Guerra Mundial houve um esforço de guerra - do qual várias empresas participaram - para a produção de armamentos e equipamentos de guerra, e ocorreu uma expansão do número de empresas que implantaram o serviço odontológico.

Alguns órgãos, como a ADA e Associações profissionais estaduais, procuraram estabelecer padrões para a implantação desses serviços nas empresas. Como exemplos podemos citar a Seção Odontológica da Divisão de Higiene Industrial do Departamento de Saúde para Programas Odontológicos Industriais da Sociedade Odontológica do Estado da Pensilvânia; o padrão mínimo preconizado pela ADA (ADA, 1942); as recomendações para Programas Industriais adotadas pela Casa de Delegados da Sociedade Odontológica do Estado da Pensilvânia em maio de 1944 (Aston, 1946); e a Sociedade Odontológica do Estado de Illinois, que forneceram parâmetros à implantação de serviços odontológicos em empresas.

No Brasil, poucos trabalhos registram essa evolução. Medeiros \& Bijella (1970) relatam que, no nosso país, a assistência ao trabalhador surgiu com as leis de proteção social da década de 30 .

Pimentel et al. (1961) ressaltam a importância de um consultório odontológico instalado na indústria para atender os trabalhadores, mas não houve interesse por parte dos empresários. Medeiros (1965) realizou uma pesquisa em duas empresas do setor automobilístico (uma com 700 e outra 
com 3800 trabalhadores) no período de 1960 a 1963, e relatou a importância do exame odontológico pré-admissional.

Alguns trabalhos abordaram e procuraram delinear os requisitos para a elaboração de programas odontológicos para os trabalhadores, com base na então denominada odontologia do trabalho (Medeiros, 1966; Medeiros \& Bijella, 1970; Medeiros \& Bijella, 1971; Nogueira, 1972; Sbrissa Netto et al., 1975; Pimentel, 1976; Birman, 1979; Guimarães \& Rocha, 1979a, b, c; Esteves et al., 1980; Gomes \& Magalhães, 1980; Carvalho, 1981; Birman et al., 1982; Esteves, 1982; Silva \& Souto, 1983a, b, c; Ferraz \& Bellini, 1983; Motta \& Albuquerque, 1983; Passos \& Villela, 1983; Motta \& Toledo, 1984; Garrafa, 1986a,b; Peres, 1989; Ferreira, 1994; Caetano \& Watanabe, 1994; Ferreira, 1995; Midorikawa \& Nagano, 1995; Baroni, 1996; SESI, 1996; Midorikawa et al. , 1996; Ferreira, 1997; Araújo, 1998; Schüler Sobrinho, 1998; Araujo \& Gonini Jr., 1999; Pinto, 2000).

No Brasil, segundo o Instituto Brasileiro de Geografia e Estatística (IBGE), em 1996 a população era de 157.070 .163 habitantes (IBGE, 2000) e, em 1997, para o Ministério da Saúde, nossa população era de 159.636.413 habitantes (Brasil, 2000b)

A Tabela 2 mostra a freqüência e a porcentagem de distribuição da população pelas regiões brasileiras em 1997. Observa-se uma concentração de população nas regiões sudeste $(42,6 \%)$, nordeste $(28,4 \%)$ e sul $(15 \%)$. 
Tabela 2 - Freqüência e porcentagem de distribuição da população pelas regiões geográficas. Brasil, 1997.

\begin{tabular}{l|c|c}
\hline Regiões & Número de habitantes & $\%$ \\
\hline Norte & 11.604 .158 & 7,3 \\
Nordeste & 45.334 .385 & 28,4 \\
Sul & 23.862 .664 & 15,0 \\
Sudeste & 68.065 .957 & 42,6 \\
Centro-Oeste & 10.769 .249 & 6,7 \\
\hline Brasil & $\mathbf{1 5 9 . 6 3 6 . 4 1 3}$ & $\mathbf{1 0 0 , 0}$ \\
\hline
\end{tabular}

Fonte: Ministério da Saúde (2000)

No Brasil temos, atualmente, 157.716 cirurgiões-dentistas, e a Tabela 3 mostra que sua distribuição geográfica é irregular, havendo uma clara concentração na região sudeste - $62,1 \%$ dos CDs - e uma grande escassez na região norte, que apresenta somente $2,8 \%$ do total nacional de profissionais da área.

Tabela 3 - Freqüência e porcentagem da distribuição dos CDs pelas regiões geográficas. Brasil, 2000.

\begin{tabular}{l|c|c}
\hline Regiões & Número de CDs & $\%$ \\
\hline Norte & 4.440 & 2,8 \\
Nordeste & 20.617 & 13,1 \\
Sul & 23.218 & 14,7 \\
Sudeste & 97.894 & 62,1 \\
Centro-Oeste & 11.547 & 7,3 \\
\hline Brasil & $\mathbf{1 5 7 . 7 1 6}$ & $\mathbf{1 0 0 , 0}$ \\
\hline \multicolumn{2}{|c}{} \\
\end{tabular}

Para avaliar a distribuição de CDs nas várias regiões do Brasil podemos aliar os dados de população de 1997 e os dados do CFO de 2000, o que nos fornecerá a seguinte concentração de CDs por Regiões do Brasil: 
Tabela 4 - Concentração de CDs por habitantes nas regiões geográficas. Brasil, 2000

\begin{tabular}{l|c}
\hline Regiões & Número Habitantes/CD \\
\hline Norte & 2.614 \\
Nordeste & 2.199 \\
Sul & 1.028 \\
Sudeste & 695 \\
Centro-Oeste & 933 \\
\hline Brasil & $\mathbf{1 . 0 1 2}$ \\
\hline
\end{tabular}

Fonte: CFO (2000)

Considerando que a Organização Mundial da Saúde preconiza, como relação boa, a de 1 CD para 1.500 habitantes, percebemos que há uma má distribuição dos CDs pelas regiões brasileira, com acentuada concentração na região sudeste (695 hab./CD) do país.

A tabela 5 mostra os indicadores positivos de saúde bucal no Brasil segundo a faixa etária. Os dados são de 1986.

Tabela 5 - Indicativos positivos de saúde bucal, segundo grupo etário. Brasil, zona urbana, 1986.

\begin{tabular}{c|c|c|c|c|c}
\hline $\begin{array}{c}\text { Grupo } \\
\text { etário }\end{array}$ & $\begin{array}{c}\% \text { dentes } \\
\text { hígidos }\end{array}$ & $\begin{array}{c}\text { \% com } \\
\text { Atendimento } \\
\text { Odontológico }\end{array}$ & $\begin{array}{c}\text { \% livre de } \\
\text { Prótese } \\
\text { Total }\end{array}$ & $\begin{array}{c}\% \text { com } \\
\text { dentes }\end{array}$ & $\begin{array}{c}\% \text { sem } \\
\text { Doença } \\
\text { Periodontal }\end{array}$ \\
\hline $15-19$ & 62,71 & 60,49 & 98,41 & 99,77 & 27,96 \\
$20-24$ & 55,73 & 57,71 & 89,23 & 98,67 & 24,19 \\
$25-29$ & 48,95 & 54,99 & 89,00 & 96,59 & 21,01 \\
$30-34$ & 41,98 & 52,25 & 80,90 & 93,64 & 17,43 \\
$35-39$ & 34,41 & 40,50 & 71,03 & 85,43 & 14,16 \\
$40-44$ & 28,65 & 46,73 & 59,91 & 81,76 & 9,01 \\
$45-49$ & 22,54 & 43,97 & 48,20 & 69,51 & 9,42 \\
$50-54$ & 16,99 & 41,24 & 36,64 & 60,27 & 7,08 \\
$55-59$ & 12,09 & 38,54 & 25,87 & 50,68 & 5,21 \\
$60-64$ & 7,92 & 35,90 & 16,51 & 41,13 & 3,62 \\
$65-69$ & 4,58 & 33,20 & 8,75 & 31,52 & 2,26 \\
$70-74$ & 2,13 & 30,81 & 3,69 & 23,10 & 1,31 \\
$75-79$ & 0,63 & 28,35 & 1,17 & 15,44 & 0,68 \\
\hline
\end{tabular}


O estudo da saúde bucal da população brasileira, baseado em dados do "Levantamento Epidemiológico em Saúde Bucal: zona urbana, 1986" realizado pelo Ministério da Saúde (1988), revelou que há uma perda rápida da higidez dos dentes com a idade; desta forma, entre 40 e 44 anos, os brasileiros mantêm apenas 30\% dos dentes sadios (Pinto, 1993). Em decorrência da diminuição da incidência de cáries, e do aumento das extrações dentárias com o avançar da idade, a porcentagem de pessoas que visitaram consultórios odontológicos é alta, com queda gradativa relacionada ao aumento da faixa etária. Quanto à prótese total, até o grupo etário de 25 a 29 anos nove entre cada dez indivíduos não necessitam desse recurso, mantendo a dentição em condições funcionalmente aceitáveis. Já no que concerne à doença periodontal, poucos estão livres dela e, no grupo etário de 75 a 79 anos, apenas $7 / 1000$ habitantes não apresentam esse quadro (Tabela 5).

Na Tabela 6 constata-se que o índice CPOD é alto e, no grupo etário de 30 a 34 anos, chega a atingir metade dos dentes $(18,533)$. Com relação ao componente $\mathrm{O}+\mathrm{E}$ (dentes Obturados mais dentes Extraídos), que representa o índice de problemas resolvidos, percebemos que ele aumenta com a idade, atingindo mais da metade dos dentes no grupo de 40 a 44 anos $(22,795)$; os componentes C + Ei (dentes Cariados mais dentes com Extração indicada), que representam as necessidades de tratamento, tendem a se manter estáveis durante a maior parte dos grupos etários mais produtivos (de 15-19 a 35-39), declinando com o avançar da idade porque os 
dentes cariados não recebem tratamento oportuno por dificuldade de acesso ao consultório odontológico, culminando com a extração dentária.

Tabela 6 - Índices de CPOD e seus componentes, segundo os grupos etários. Brasil, zona urbana, 1986.

\begin{tabular}{c|c|c|c}
\hline Grupo etário & CPOD médio & O + E média & C + Ei média \\
\hline $15-19$ & 10,782 & 6,471 & 4,311 \\
$20-24$ & 14,166 & 8,974 & 5,192 \\
$25-29$ & 14,543 & 11,493 & 3,050 \\
$30-34$ & 18,533 & 14,142 & 4,391 \\
$35-39$ & 20,951 & 16,862 & 4,089 \\
$40-44$ & 22,795 & 19,550 & 3,245 \\
$45-49$ & 24,763 & 22,156 & 2,607 \\
$50-54$ & 26,541 & 24,570 & 1,971 \\
$55-59$ & 28,105 & 26,721 & 1,384 \\
$60-64$ & 29,435 & 28,563 & 0,872 \\
$65-69$ & 30,541 & 29,981 & 0,560 \\
$70-74$ & 31,301 & 30,916 & 0,385 \\
$75-79$ & 31,788 & 31,571 & 0,217 \\
\hline
\end{tabular}

Fonte: Pinto (1993)

A Pesquisa de Acesso e Utilização de Serviços de Saúde realizada pelo IBGE em 1998 mostrou que 20\% dos brasileiros (mais de 31.927.283) nunca foram a um consultório odontológico (Athias, 2000).

A porcentagem de edêntulos aumenta com o grupo etário e, segundo Pinto (1993), a necessidade de prótese total aumenta de 10\% - no grupo de 20-24 anos - para 20\% - na faixa de $30-34$-, $80 \%$ entre $60-64$ anos até $98 \%$ no grupo de $75-79$ anos. A doença periodontal é alta em todas as faixas etárias, indo de $72 \%$ no grupo etário de 15-19 anos até 90\% no grupo de 45-49 anos (Tabela 7). 
Tabela 7 - Porcentagem de pessoas edêntulas, de pessoas que necessitam de prótese total e tratamentos para doença periodontal, segundo grupo etário. Brasil, zona urbana, 1986.

\begin{tabular}{c|c|c|c}
\hline Grupo etário & $\begin{array}{c}\text { \% Pessoas } \\
\text { edêntulas }\end{array}$ & $\begin{array}{c}\text { \% Pessoas que } \\
\text { necessitam e/ou } \\
\text { possuem Prótese Total }\end{array}$ & $\begin{array}{c}\text { \% Pessoas com } \\
\text { Doença Periodontal } \\
\text { (CPITN) }\end{array}$ \\
\hline $15-19$ & 0,226 & 1,593 & 72,039 \\
$20-24$ & 1,334 & 5,405 & 75,808 \\
$25-29$ & 3,405 & 10,997 & 78,988 \\
$30-34$ & 6,362 & 19,101 & 82,572 \\
$35-39$ & 14,566 & 28,974 & 85,842 \\
$40-44$ & 21,981 & 40,090 & 90,992 \\
$45-49$ & 30,491 & 51,801 & 90,584 \\
$50-54$ & 39,725 & 63,359 & 92,924 \\
$55-59$ & 49,319 & 74,128 & 94,794 \\
$60-64$ & 58,872 & 83,486 & 96,381 \\
$65-69$ & 68,476 & 91,250 & 97,741 \\
$70-74$ & 76,895 & 96,309 & 98,687 \\
$75-79$ & 84,562 & 98,828 & 99,129 \\
\hline
\end{tabular}

Fonte: Pinto (1993)

Hoje, vivemos um momento em que a odontologia desempenha importante papel como benefício assistencial de saúde, sendo oferecida pelas empresas aos seus empregados através de empresas de odontologia de grupo, autogestão, etc. Essa mudança de cultura ocorre porque as empresas fazer, desse benefício, um diferencial a ser oferecido aos seus funcionários (Associação Paulista de Administração de Recursos Humanos, 1998).

Segundo o Sindicato Nacional das Empresas de odontologia de Grupo (SINOG) existem cerca de 250 empresas atuando no Brasil, com a estimativa de 80.000 CDs credenciados atendendo a uma população de dois 
milhões de pessoas. A Uniodonto do Brasil (Confederação Nacional das Cooperativas Odontológicas) congrega hoje 170 singulares, com mais de 15.000 CDs cooperados atendendo a cerca de 3 milhões de usuários.

A Associação Brasileira dos Serviços Assistenciais de Saúde Próprios de Empresas (ABRASPE), e o Comitê de Integração de Entidades Fechadas de Assistência à Saúde (CIEFAS), são entidades que congregam empresas que mantêm programas de saúde em sistemas de autogestão aos empregados e dependentes e, juntas, chegam a contemplar uma população de 19,7 milhões de pessoas.

A última pesquisa realizada pelo CIEFAS, em 1999, contemplou 250 empresas de autogestão, e teve retorno de 87 questionários. O custo per capita de odontologia era de $\mathrm{R} \$ 9,79$ sendo que $65 \%$ das empresas oferecem assistência odontológica. A ABRASPE relatou que, em 2000, das 300 empresas de todo o país contatadas, apenas 84 responderam o questionário e, destas, 66,7\% oferecem assistência odontológica, com um custo per capita de $\mathrm{R} \$ 8,79$ (Associação Brasileira dos Serviços Assistenciais de Saúde Próprios de Empresas, 2000; Comitê de Integração de Entidades Fechadas de Assistência à Saúde, 2000; Sindicato Nacional das Empresas de Odontologia de Grupo, 2000; UNIODONTO do Brasil, 2000). 


\subsection{A IMPORTÂNCIA DA SAÚDE BUCAL}

\subsubsection{ASPECTO PSICOLÓGICO E COMPORTAMENTO SOCIAL}

Segundo Vasconcellos (1998), “a boca é o órgão mais central na vida do ser humano". A boca garante a subsistência, proporciona prazer, estabelece comunicação com o meio ambiente e ainda expressa as emoções, os sentimentos e as tensões que vivenciamos.

Para Guimarães \& Rocha (1979a), a boca é um órgão de expressão emocional, que reflete as manifestações da mente, transmite os sentimentos de felicidade, de alegria, de raiva e de prazer, o canto e o riso, o pranto e a blasfêmia. Assim, do ponto de vista "psicossomático" a boca é, provavelmente, o órgão mais importante do corpo humano.

O trabalhador que tem boas condições de saúde bucal pode manifestar os seus sentimentos através do sorriso, desinibidamente ou com expressão extrovertida e sociável. Em contrapartida, o trabalhador que tem problemas odontológicos sente dor, sofre desconforto, sente-se esteticamente diminuído ou estressado, e manifesta vários sinais e sintomas, que vão desde a diminuição de atenção no trabalho (absenteísmo de corpo presente) até à falta ao trabalho (absenteísmo), além de comportamentos sociais de tristeza - como a "cara fechada" - a inibição demonstrada pela vergonha de sorrir, de falar em público, de se relacionar com as pessoas etc. 


\subsubsection{ALGUNS PROBLEMAS NA CAVIDADE BUCAL}

\subsubsection{CÁRIE DENTÁRIA}

Em 1994, Thylstrup \& Fejerskov apud Ekstrand (2000) descreveram a cárie dentária "como um processo dinâmico que ocorre nos depósitos bacterianos (placa bacteriana presente na superfície dos dentes), resultando em uma alteração do equilíbrio entre a superfície dentária e o fluído da placa, que com o passar do tempo, leva à perda de mineral".

Para Hume (1997 apud Ekstrand, 2000), a cárie é uma "doença bacteriana relacionada à placa, que ocorre na superfície dentária, dependente da presença de açúcares simples na dieta e da freqüência de ingestão de carboidratos fermentáveis, modificada pela presença de flúor e composição salivar".

A deficiência na higiene bucal provoca o acúmulo de placa bacteriana na superfície do dente. Este lança produtos ácidos que levarão a uma diminuição do pH (acidez) do meio ambiente bucal, acarretando uma desestruturação dos cristais de hidroxiapatita que compõem o esmalte do dente. Essa desestruturação ocasiona a perda gradual de minerais do esmalte do dente que como resultado, clinicamente, origina uma alteração da translucidez do esmalte, que passa de um tom brilhante a uma mancha branca opaca na região do processo.

A continuidade deste processo leva o dente a outras mudanças estruturais, que culminam com o surgimento de uma cavidade, com ou sem comprometimento da dentina. $\mathrm{O}$ dente reage produzindo uma dentina reparadora e, nesta fase, podem aparecer sintomas de dor ao contato com alimentos sólidos ou líquidos, quentes e/ou frios. 
O trabalhador com dor-de-dente terá a qualidade da sua alimentação e sono comprometidos e, conseqüentemente, sua capacidade laborativa produtiva diminuída. Além disso, a falta de concentração aumenta o risco de ocorrência de acidentes de trabalho.

Caso a cárie dentária não seja tratada, o processo continua evoluindo em velocidade mais rápida que o processo de defesa do dente, até atingir a polpa, onde se localizam os vasos sangüíneos e linfáticos e o nervo do dente, levando a problemas endodônticos ou de canal.

\subsubsection{Dentes COM ALTERAÇões PULPaRes}

Como conseqüência da evolução da cárie dentária - resultante da soma das ações das toxinas e ácidos -, e dependendo das condições intrínsecas de defesa e da resistência da polpa dental, poderá ocorrer uma reação inflamatória, denominada pulpite aguda. Esta se caracteriza pelas seguintes manifestações clínicas: dor aguda, espontânea, localizada ou difusa, pulsátil, reflexa, intermitente ou contínua e exacerbada pelo frio (Leonardo \& Leal, 1991).

A pulpite pode evoluir para a pulpite aguda purulenta - dependendo do grau de virulência da bactéria e da defesa do órgão pulpar -, que se caracteriza por: dor aguda, espontânea, intolerável, localizada (geralmente), pulsátil, contínua, exarcebada pelo calor, aliviada pelo frio e dor à percussão vertical. Também pode evoluir lentamente para pulpite crônica quando a 
irritação sobre a polpa for de baixa intensidade e de longa duração, capaz de resistir à ação irritante.

Finalmente, pode chegar a uma necrose pulpar (morte da polpa), que implica a perda dos processos metabólicos do dente, sua vitalidade e defesas naturais.

Em qualquer uma destas situações, o trabalhador provavelmente teve queda da produtividade (absenteísmo de corpo presente), da atenção no trabalho, queda na qualidade da alimentação, na qualidade e na quantidade de sono, alteração do humor e absenteísmo.

\subsubsection{DENTES COM ALTERAÇÕES PERIAPICAIS}

Tanto a necrose (morte da polpa) quanto a gangrena - que é a morte da polpa seguida pela invasão bacteriana - permitem que o tecido em decomposição e desintegração se torne uma via de acesso das bactérias ao periápice.

Os produtos tóxicos da decomposição pulpar, os microorganismos e suas toxinas, exercerão ação sobre o tecido periapical originando várias formas de reação, que podem ser divididas em:

> AlteRAÇões PERIAPICAIS AGUdAs: periodontites apicais agudas e abscessos dentoalveolares agudos;

> ALTERAÇõES PERIAPICAIS CRÔNICAS: abscessos dentoalveolares crônicos, granulomas e cistos.

O abscesso dentoalveolar agudo caracteriza-se por dor espontânea, pulsátil e localizada, extrusão dental, dor à percussão, mobilidade dental, 
congestionamento de mucosa ao na região do ápice radicular, sensibilidade a palpação na região do ápice radicular, ausência de vitalidade pulpar e ausência ou não de edema.

O granuloma periapical consiste de uma cápsula de tecido conjuntivo circundando uma massa de tecido de granulação. Desenvolve-se como uma reação defensiva corpórea a um grande número de irritantes locais - não necessariamente de natureza bacteriana - suficientes para conter a agressão. O local contém bactérias, toxinas e uma via de ligação com a corrente sangüínea fornecida pela presença de vasos na cápsula fibrosa. Esta comunicação pode permitir que as bactérias, através da corrente sangüínea, atinjam outras partes do corpo.

O trabalhador que é acometido, principalmente pelas alterações agudas, apresenta um quadro semelhante àquele descrito no item anterior, com queda da produtividade, fadiga, desatenção no trabalho, queda na qualidade da alimentação, na qualidade e na quantidade de sono, alteração do humor e absenteísmo.

\subsubsection{DOENÇA PERIODONTAL}

As doenças periodontais dividem-se em gengivites e periodontites.

As gengivites são definidas como inflamações da gengiva, pois a placa bacteriana que causa a inflamação e os fatores irritantes que favorecem ao acúmulo de placa estão presentes. Existem diferentes tipos de gengivites, e algumas podem levar a um processo doloroso e/ou ao 
desconforto, causando diminuição da atenção e da produtividade do trabalhador.

A periodontite é, de acordo com Lascala \& Moussalli (1995), uma "lesão inflamatória de caráter infeccioso que envolve os tecidos de suporte dos dentes, causando perda da inserção conjuntiva, do osso alveolar e de cemento radicular".

Vários são os tipos de periodontites, e estas geralmente são precedidas pela gengivite. Devido a deficiências na higiene bucal, com o passar do tempo a placa bacteriana acumulada absorve o cálcio, formando o cálculo.

Caso a periodontite não seja tratada, resultará em intensa inflamação gengival, sangramento, perda de inserção com formação de bolsas periodontais ou recessão gengival, perda de osso alveolar, halitose e supuração ocasional.

A mobilidade dos dentes pode atingir vários milímetros e resultar na sua perda; às vezes a bolsa periodontal pode infeccionar e originar 0 abscesso periodontal, que apresenta sintomatologia dolorosa e, conseqüentemente, acarreta diminuição da atenção no trabalho.

Em 1950, Miller (apud Guidigli, 1988) relatou que pode ocorrer a disseminação bacteriana pelo periodonto através do sangue e da linfa, por direta extensão aos tecidos, por contigüidade com os tratos gastrointestinal e respiratório, pela deglutição e pela aspiração do material infectado. As conseqüências desta disseminação serão abordadas no item bacteremia. 
A perda dos dentes causa dificuldade mastigatória, com prejuízo da qualidade nutricional e escolha dos tipos de alimentos da dieta, dificuldade de dicção e, em casos agudos, absenteísmo para procurar sanar a urgência odontológica.

\subsubsection{CIRURGIAS OdONTOLÓGICAS - EXOdONTIA}

A indicação de cirurgias odontológicas segue os princípios da necessidade e da oportunidade.

$\mathrm{Na}$ necessidade verifica-se a doença, a amplitude do envolvimento anatomofuncional, os tipos de estruturas anatômicas envolvidas e as seqüelas possíveis. Quanto ao doente, verificam-se as condições de saúde local e sistêmica para a oportunidade do ato cirúrgico.

As extrações dentárias decorrentes de doença periodontal avançada ou de cárie dentária extensa abrem caminhos nos tecidos gengival e ósseo, de comunicação direta do meio externo (cavidade bucal) com o meio interno, permitindo que ocorra a bacteremia.

O trabalhador que não tenha bons hábitos de higiene bucal pode ter seus dentes afetados por tais doenças. Com a evolução destas, pode chegar a uma situação tal que só reste a exodontia como solução terapêutica.

Até este ponto, novamente o trabalhador passou pelas outras fases citadas acima, com todas aquelas conseqüências possíveis. $E$, em decorrência da cirurgia, perderá mais horas de trabalho; se essa cirurgia 
ocorrer sem prévio planejamento - em situações de urgência - causará transtornos na organização do trabalho da empresa.

\subsubsection{DESORDENS TEMPOROMANDIBULARES}

Okeson (1992) informa que as atividades do sistema mastigatório dividem-se em funcional e parafuncional.

As atividades funcionais incluem os atos de mastigar, falar e deglutir, e as parafuncionais contemplam o apertar ou ranger os dentes (bruxismo ou briquismo) e outros hábitos bucais.

Os movimentos parafuncionais podem ocorrer durante o dia - ranger ou apertar os dentes, morder a bochecha ou a língua sem perceber, chupar o dedo, morder o lápis, a unha etc. - ou à noite, durante o sono - episódios unitários de apertar os dentes ou contrações ritmadas (bruxismo) -, e podem provocar desordens temporomandibulares.

Se a influência combinada da maloclusão e do estresse emocional for maior do que a tolerância fisiológica da pessoa, ocorre o aumento da hiperatividade muscular. Quando esta hiperatividade é maior do que a tolerância estrutural pode provocar um colapso do sistema mastigatório, com conseqüências em várias estruturas.

As desordens temporomandibulares podem ser: desordens funcionais dos músculos e/ou desordens funcionais das articulações temporomandibulares e/ou desordens funcionais da dentição associadas ou 
não a outros sinais e sintomas como dor de ouvido, barulho ou entupimento do ouvido, zumbido e vertigem.

Autores como Helöe et al. (1977) e Morse (1982) encontraram relação entre as desordens temporomandibulares e o estresse provocados pelas condições de trabalho, enquanto outros autores (Hirsch et al., 1982; Bryant, 1989; Zimmers \& Gobetti, 1994) demonstraram que tocar alguns instrumentos musicais, como o violino, pode causar desordens temporomandibulares, o que pode ser caracterizados como doença profissional.

O trabalhador pode, de uma hora para a outra, apresentar sintomatologia de desconforto e até mesmo de dores intensas nessas estruturas isoladas ou associadas, o que provoca a falta ao trabalho, a diminuição da concentração no trabalho etc.

\subsubsection{HALITOSE}

Tarzia (1991) define a halitose como sendo uma "condição anormal do hálito na qual este se altera de forma desagradável tanto para o paciente como para as pessoas com as quais ele se relaciona". Essa manifestação é também conhecida como hálito fétido, mau hálito e fedor da boca.

Uma das classificações da halitose secundária (cavidade bucal e vias aéreas superiores) local por processos patológicos é:

- De origem bucal:
a. Doença periodontal
b. Cárie dental 
c. Cicatrização de feridas cirúrgicas (halitose temporária)

d. Estomatites

e. Neoplasias

f. Cisto dentigero

g. Mí́ases

h. Pobre higiene oral

○ De origem não-bucal

a) Amigdalite

b) Faringite

c) Sinusite

d) Adenóide

e) Fossas nasais

f) Corpos estranhos

A halitose traz problemas ao trabalhador porque acaba restringindo sua vida social e, para algumas pessoas, o medo de tê-la pode desencadear uma neurose. Pode significar anormalidade ou doença em outro órgão do corpo, sendo importante auxiliar no diagnóstico de algumas doenças - bucais ou não -, além de poder significar intoxicação profissional (McCord, 1950; Nogueira, 1972).

\subsubsection{BACTEREMIA}

Guidugli Neto (1988) relata que a teoria da infecção focal foi tão importante e preocupou tanto médicos, dentistas quanto leigos porque era ele (leigo) o mais ameaçado. 
O primeiro documento que cita a infecção focal foi encontrado em Luxor, no Egito, e data de 3.700 a 1.500 a.C.; nele um médico escreveu: "As dores nas costas, na tua cabeça e nos teus pés provêm de teus dentes. Não recuperarás a saúde antes de deixa-los extirpar".

Essa teoria baseou-se na idéia de que os focos infecciosos, por exemplo dentais, verteriam seus produtos tóxicos na circulação sangüínea, em quantidade mínima mas de forma contínua e prolongada, dando origem a um estado séptico latente que poderia desencadear uma infecção em outro órgão.

Com base nesse conceito, trabalhos realizados no início do século procuraram esclarecer, mas trouxeram uma acentuada confusão sobre o assunto, pois calcavam-se predominantemente em evidências clinicas. Autores como Thomas (1918), Price (1923), Thomas (1940), Austin (1940), Miller (1941), Goldhorn (1942), Hooper (1943), Thomas (1943), Morrey (1944), Misher (1946), Sappington (1946), Goldhorn (1947), Dunning (1952), pesquisaram a matéria, chegando a várias possíveis relações e dúvidas, e recomendam novas pesquisas, pois nem todas as infecções sistêmicas em órgãos do corpo humano têm origem bucal.

De forma geral, essa teoria ressalta a localização dos microorganismos em um foco de infecção, como por exemplo os tecidos bucais e as tonsilas; a disseminação ocorre através das correntes sangüínea e linfática e a ação se dá em outro órgão do corpo. 
Bacteremias assintomáticas ocorrem tanto em procedimentos odontológicos terapêuticos como nos procedimentos de higiene bucal caseira e na mastigação dos alimentos.

Para Guidugli Neto (1988), a doença periodontal é um forte predisponente à bateremia devido ao grande número de vasos sangüíneos que irrigam o periodonto e que permitem uma rápida saída de microrganismos da bolsa periodontal.

Em uma revisão da literatura, Egbert et al. (1999) encontraram que a bacteremia assintomática em pacientes saudáveis e aquela relacionada às infecções da cavidade bucal podem ser mais nefastas que as bacteremias decorrentes de intervenções clínicas odontológicas. E relacionam as bacteremias de doenças periodontais às alterações cardiovasculares, às infecções pulmonares e ao parto prematuro.

Guidugli Neto (1988) escreveu que a endocardite bacteriana "é uma doença causada pela disseminação de um agente infectante, a partir de um foco, no revestimento interno do coração ou de um grande vaso sanguineo, sendo reconhecidas a forma subaguda e a aguda". Já para Otomo-Corgel (1997), a endocardite infecciosa é uma "doença na qual microrganismos colonizam o endocárdio danificado ou as válvulas cardíacas"; o autor prefere essa denominação - endocardite infecciosa - porque a endocardite pode ser causada por fungos ou vírus também.

O Conselho Regional de Odontologia de São Paulo - CROSP (2000) - lançou uma campanha com o slogan "O dente pode matar", na qual 
procura alertar a população sobre os riscos a que está exposta se não der devida atenção à saúde bucal.

Em entrevista ao jornal do CROSP (2000), Grinberg relata que

"o INCOR, que é um centro de referência na doença, registra a cada mês entre dez a doze pacientes com endocardite. Cerca de $40 \%$ destes casos têm origem bucal e são desencadeados por infecções espontâneas, resultantes de dentes ou gengivas em mal estado, quando pela manipulação de área infectada para tratamento odontológico".

As doenças articulares são classicamente relacionadas à artrite reumatóide e à febre reumática, mas não há comprovação dessa interface. As moléstias gastrointestinais, as moléstias oculares, a moléstia de pele e as moléstias renais também carecem de pesquisas mais aprofundadas para comprovação de sua relação com as infecções da boca.

\subsubsection{MAStigaçÃo E DigeStão}

Para Guimarães \& Rocha (1979a) e Gobbato (1998), a boca é a porta de entrada para o sistema digestivo local; nela inicia a digestão, com o corte, a mastigação e a trituração dos alimentos, para a formação do bolo alimentar. A deglutição do alimento facilita a atuação do esôfago e do estômago na continuação do processo digestivo.

Quando há ausência de elementos dentários, o trabalhador pode ter problemas quanto à escolha da dieta a ser consumida, pois alimentos mais consistentes ("duros") serão deixados de lado. Isto poderá originar problemas nutricionais, queda da resistência do organismo, pois o alimento ingerido, quando é subtriturado na cavidade bucal, provoca uma sobrecarga 
ao aparelho digestivo que, a longo prazo, pode ser acometido por alguma doença.

Além disso, a boca é a rota de entrada de substâncias tóxicas para dentro do corpo. Essa ingestão acidental ou por baixa absorção leva a várias manifestações na língua, nos dentes, na bochecha etc.

\subsubsection{ALGUNS ASPECTOS FONOAUDIOLÓGICOS}

O trabalhador que tem alteração respiratória, como por exemplo o respirador bucal, terá dificuldades de mastigação, de deglutição, de ressonância vocal e até de coordenação entre a respiração e a fala. Além disso, perde o filtro nasal natural e, se trabalhar em ambiente com partículas em suspensão, tem maior facilidade a aspirar agentes tóxicos (Gobbato, 1998).

O aparelho fonador é composto por laringe, lábios, língua, palato mole, maxilar, mandíbula, pregas vocais e dentes, que pertencem ao mesmo tempo aos sistemas digestivo e respiratório. Assim, alterações em um dos seus componentes poderão acarretar em problemas na fala. Podemos citar como exemplo a falta de dentes que servem de apoio para a pronúncia de fonemas ditos dentais $(t, d, n)$, de fonemas labiais ( $f, v)$, etc., que dificulta a correta pronúncia e também o entendimento entre as pessoas, situação que, em um ambiente de trabalho, pode causar muitos transtornos (Tamaki, 1983; Okeson, 1992; Areias, 1998) e riscos de acidentes, pela dificuldade de comunicação e/ou entendimento de orientações e avisos. 


\subsection{ABSENTEÍSMO POR CAUSA ODONTOLÓGICA}

Segundo a subcomissão de Absenteísmo da Associação Internacional de Medicina do Trabalho, o absenteísmo ou absentismo é "a ausência dos trabalhadores ao trabalho, naquelas ocasiões em que seria de esperar a sua presença, por razões de ordem médica ou quaisquer outras". (Tenório e Jordano, 1980)

Há dois tipos de absenteísmo: o absenteísmo pela falta ao trabalho e o absenteísmo de corpo presente.

O absenteísmo tipo I (pela falta ao trabalho) é mais fácil de ser mensurado e de ter o seu custo calculado. É a falta pura e simples do empregado ao trabalho, que leva à perda de produção das horas não trabalhadas.

O absenteísmo tipo II (de corpo presente) é aquele que ocorre quando o trabalhador está com algum problema de saúde que não permite um melhor desempenho e, embora ele não falte ao trabalho, diminui a sua produtividade. As doenças bucais, como a cárie, a doença periodontal etc., podem muitas vezes levar a um quadro de sintomatologia dolorosa de pouca intensidade; assim, o empregado tolera durante dias, eventualmente durante semanas, a dor e o desconforto, antes de procurar ajuda profissional para o tratamento e a resolução do problema. Hooper (1942) relata que pelo menos 25\% do absenteísmo por doenças não-ocupacionais está diretamente relacionada às condições orais. 
Heacock (1943) relata que, em dezembro de 1942, o serviço médico de uma indústria de mais de meio milhão de trabalhadores informou-lhe que o absenteísmo por doenças dos dentes e das gengivas em homens foi da ordem de 0,8 pessoas por 1000 empregados, com uma duração de 27 dias. Muitas desordens dentárias provocavam ausências de menos de 7 dias por caso, o que levou o autor a concluir que havia muito casos sérios nessa empresa.

Para Kulstad (1945), um grande número de ausências ao trabalho decorre de problemas não-ocupacionais, e a maior parte do absenteísmo ocupacional e não-ocupacional - é complicada ou agravada por doenças dentais.

Estudando o absenteísmo causado por problemas de dentes e de gengiva, Puffer \& Sebelius (1946) pesquisaram indústrias do Tennessee, entre 1944 e 1945, e encontraram que as ausências de um dia ou mais eram de 47,3 por 1000 empregados, com uma razão de 0,210 dias por empregado.

Dunning (1952) reforça a importância da absenteísmo decorrente de problemas odontológicos, e lembra que sua proporção é pequena em relação ao total de absenteísmo porque só são computadas como tal as faltas caracterizadas por manifestações localizadas nos dentes e nas gengivas, sem que se leve em consideração as remotas seqüelas da infecção dental; além disso, tais ausências são geralmente associadas a tratamentos curativos para alívio dos sintomas agudos, que podem ser prevenidos. 
Rice (apud Medeiros, 1965) declarou que, em 1957, na Inglaterra, a indústria perdeu 527.000 dias/trabalho por problemas dentários dos trabalhadores, com ausência de 4 ou mais dias, e estimou em 1.000.000 dias/trabalho as ausências de curta duração provocadas por tais intercorrências.

A dor de dentes ocupa $\circ 3^{\circ}$ lugar entre as causas de faltas ao trabalho, perdendo apenas para a dor de estômago e a dor de cabeça (Pimentel, 1976; OMS, 1980 apud Borrás \& Sanfilippo, 1988).

Analisando uma construtora do Rio de Janeiro, Tenório \& Jordano (1980) encontraram que, em 1976, as causas odontológicas foram responsáveis por $27,27 \%$ das faltas ao trabalho, com perda de 999 dias/trabalho e, no ano seguinte, por 30,72\%, com uma perda de 2081 dias/trabalho.

Em 1979, nos EUA, as condições dentais agudas resultaram em 6,1 milhões de dias de trabalho perdido ou 6,0 dias/100 trabalhadores (Schou, 1989). E, em 1983, 6.116.240 dias de trabalho - com 5,8 dias/100 pessoas/ano - foram perdidos por problemas odontológicos naquele mesmo país (Ayer et al., 1986).

Segundo Baroni (1996), a Unidont/Prevenire Consultoria e Prevenção em Odontologia realizou uma pesquisa com 12 mil trabalhadores e 24 mil dependentes destes. Constatou que, entre 1993 e 1994 o absenteísmo tipo I decorrentes de causas odontológicas foi da ordem de 6670 dias/trabalho (média de 1,5 dias de falta ao trabalho); não foi possível calcular os índices do absenteísmo tipo II mas, com base nos 4.447 
atendimentos odontológico realizados, constata-se que ele existiu, pois os empregados, embora não tenham se ausentado trabalho, tiveram baixa produtividade em virtude das possíveis dores.

Como vimos, não há muitos trabalhos que demonstrem a abrangência do absenteísmo por problemas odontológicos dentro do critério absenteísmo-doença. Entretanto, e com base nos estudos até aqui relatados, acreditamos que maior atenção deve ser dada ao assunto, principalmente no Brasil, para que seja possível dimensionar de forma mais precisa os custos que essas intercorrências trazem ao sistema de produção do país.

\subsection{DEFINIÇÕES}

Ao longo do século, várias denominações foram empregadas para designar a Odontologia em Saúde do Trabalhador, principalmente após a Segunda Guerra Mundial. Para que seja possível avaliar a evolução e a conotação que essa especialidade teve até a presente data, passaremos a transcrever as definições e nomes que recebeu.

Para Petty (1943), odontologia industrial é o "serviço dental administrada por dentista ou dentistas em uma clínica ou hospital odontológico com salário ou com tarifas fixadas a serem pagas pelo empregador; pela contribuição voluntária ou involuntária, do empregado ou por algum plano de seguro". 
Em 1944, a ADA (1944) definiu a "odontologia Industrial como a especialidade da odontologia preocupada com a saúde dental do trabalhador industrial como ele influencia ou é influenciado pelo sua saúde geral e seu ambiente de trabalho" (Peffer \& Sebelius, 1946).

Ainda na década de 40 - quando era denominada odontologia industrial -, a especialidade foi definida “como a especialidade da prática dental e uma parte do programa de saúde industrial, está preocupado com a saúde dental do trabalhador como afeta ou é afetado pelo seu trabalho e seu ambiente de trabalho" (Heacock, 1946).

Em 1966, Medeiros conceituou a Odontologia do Trabalho como "o setor da odontologia que tem por finalidade a melhoria da saúde oral, seus efeitos e influência sobre a produtividade no trabalho e o diagnóstico precoce de manifestações orais de doenças ocupacionais".

E Guimarães \& Rocha (1979a) dizem que ela é "a parte da odontologia que trata de promover, preservar e reparar a saúde do trabalhador, conseqüente dos agravos, afecções ou doenças advindas do exercício profissional e que se manifestam na boca".

Com o nome de Odontologia Ocupacional, Silva \& Souto (1983a) apresentam a seguinte definição "a aplicação de todos os recursos técnicoscientíficos possíveis na odontologia na promoção e preservação do bem-estar físico, psíquico e social do homem no seu trabalho, reconduzindo-o a este estado, quando necessário".

Garrafa (1986a), que adotou a expressão Odontologia do Trabalho, arrola seus objetivos: “o estudo, interpretação e solução dos diferentes problemas 
bucais que atingem a todos trabalhadores, visualizados como participantes do processo de produção e consumo de bens, incluindo-se os próprios trabalhadores do setor saúde”.

Na mesma linha do trabalho acima, Garrafa (1986b) enfatiza a importância da Odontologia do Trabalho como uma nova especialidade dentro da odontologia, e “como a própria Medicina do Trabalho aplicada à área estomatológica, com responsabilidade pelo estudo, compreensão e solução dos problemas bucais inerentes aos trabalhadores".

Midorikawa \& Nagano (1995) definiram Odontologia do Trabalho como a "parte da odontologia que tem por objetivo prevenir, reabilitar e preservar a saúde do trabalhador dos problemas causados pelo ambiente de trabalho que aparecem na cavidade bucal”.

Para Araujo (1998), a saúde bucal dos trabalhadores é "a parte da atenção à saúde do trabalhador, que trata de promover, preservar e recuperar a saúde bucal do trabalhador, conseqüente dos agravos, afecções ou doenças do exercício profissional, e que tem manifestações bucais, devendo ter sua ação voltada à prevenção de todos os agravos laborais, ou seja, objetiva a prevenção de doenças decorrentes da atuação profissional e dos acidentes de trabalho".

Com base nas definições existentes na literatura, e na filosofia da Saúde do Trabalhador, podemos sugerir a seguinte definição:

Odontologia em Saúde do Trabalhador é a especialidade da odontologia que tem como objetivo o estudo dos fenômenos físicos, químicos, biológicos e mecânicos que atingem o complexo buco-maxilofacial, e que podem influenciar ou ser influenciados pelo ambiente de 
trabalho. Seu foco deve ser a prevenção, a reabilitação e a preservação da saúde dos trabalhadores, que podem ser atingidas pela análise, organização, planejamento, execução, avaliação de serviços, projetos ou programas de saúde bucal, avaliação técnica e perícia.

\subsection{OBJETIVOS DA ODONTOLOGIA EM SAÚDE DO TRABALHADOR}

1) Reduzir tanto o absenteísmo por causa odontológica quanto os acidentes do trabalho e as doenças profissionais que atinjam a cavidade bucal.

2) Promover e manter o estado de saúde e o bem-estar do trabalhador, sob todos os aspectos, naquilo que the compete.

3) Promover a adaptação do trabalho ao homem, para que este possa desempenhar sua tarefa de forma mais saudável e produtiva.

4) Prover o empregado de condições estético-funcionais, evitando os agravos psicossomáticos que o inibem e o conduzem a traumas de efeitos os mais diversos.

5) Prevenir ou promover a cura das doenças que acometem os dentes e os demais tecidos que compõem a cavidade bucal - com as conseqüências mais variadas para todo o organismo -, desde os processos localizados mais simples até os abrangentes, de maior gravidade.

6) Promover a conscientização dos trabalhadores sobre a importância da Saúde Bucal e sua responsabilidade neste processo. 
7) Integrar-se aos outros profissionais da área de Saúde do Trabalhador (SESMT, CIPA) para, juntos, atuarem na preservação da saúde dos trabalhadores.

8) Aumentar a eficiência industrial (produtividade) e a qualidade da produção, com a redução do tempo perdido por acidentes do trabalho e doenças profissionais.

\subsection{BENEFÍCIOS}

A meta da saúde do trabalhador é promover a saúde, a felicidade e a boa vontade dos colaboradores e, conseqüentemente, despertar neles maior lealdade e devoção para com a empresa, além de levá-los ao senso de obrigação e à simpatia. Esse interesse, transposto da empresa para a casa do trabalhador, aumenta o conforto e a felicidade da comunidade, provocando melhoria da eficiência e da capacidade produtiva, com resultados crescentes de lucro para a empresa. (Thomas, 1918)

\subsubsection{PARA O TRABALHADOR}

> Facilidade de acesso aos cuidados odontológicos, com redução do tempo de viagem e de espera, dependendo do sistema adotado pela empresa. 
> A Aprendizagem de cuidados com a Higiene Bucal permitirá ao trabalhador controlar os fatores que causam as doenças bucais, diminuindo a incidência de cáries e de doenças periodontais.

> O tratamento das doenças bucais - como restaurações de dentes cariados - promoverá diminuição do número de extrações dentárias;

> Eliminação de uma das principais causas de acidentes de trabalho, que é a dor.

> Melhoria geral da saúde, com a eliminação dos focos dentários e a possibilidade de melhor mastigação.

> Aumento do potencial de produtividade, pela melhora do estado de saúde geral que decorre dos tratamentos preventivos de que foi alvo.

> Aumento da motivação, da moral e da imagem da empresa perante o trabalhador.

\subsubsection{PARA A EMPRESA}

> Diminuição do índice de absenteísmo - tanto do tipo I quanto do tipo II pelas melhores condições de saúde bucal dos trabalhadores.

> Maior produtividade individual pelo equilibrado estado geral dos seus empregados e, conseqüentemente, melhor produção da indústria.

> Uma vez que a boca é a porta de comunicação entre o organismo e o meio ambiente, e considerando que a "saúde começa pela boca", haverá diminuição dos problemas médicos.

> Melhoria das condições bucais, que diminuirão as possibilidades de bacteremia e, conseqüentemente, de problemas médicos.

> Diminuição da possibilidade de acidentes de trabalho e de doenças profissionais que apresentem manifestações ou que atinjam a cavidade bucal. 
> Possibilidade de programar os tratamentos odontológicos, como as extrações, sem prejuízo para o andamento das atividades do trabalhador e da empresa.

> Possibilidade de abater as despesas com os serviços odontológicos na Declaração do Imposto de Renda.

> Melhoria da imagem da empresa no mercado, pois os empregados são os melhores exemplos de dignidade como conceito individual da empresa, atraindo melhores trabalhadores do mercado quando houver necessidade de recrutamento e seleção.

$>$ O investimento em saúde traz lucros indiretos

\subsubsection{PARA O BRASIL}

> Diminuição da demanda e da procura pelos serviços odontológicos dos órgãos públicos.

> Aumento da possibilidade de melhor atender a outras categorias da população necessitadas desse tipo de tratamento.

> Diminuição do índice de acidentes de trabalho e de doenças profissionais, bem como do absentismo, com o aumento da produção e conseqüente aumento da oferta do produto industrializado.

\subsubsection{PARA OS SESMTS}

> Incorporação de mais uma área de conhecimento ao grupo, melhorando a qualidade da equipe de saúde do trabalhador.

> Possibilidade de realizar um exame de saúde mais completo do trabalhador, que pode cobrir uma área importante de inter-relação da saúde pelos exames clínico e complementares da saúde bucal. 
> O cirurgião-dentista está mais familiarizado (preparado) com os efeitos dos agentes químicos, físicos, bacteriológicos e mecânicos, que apresentam manifestações precoces na cavidade oral, auxiliando a equipe de saúde do trabalhador (Schour \& Sarnat, 1942; Heacock, 1943, Nogueira, 1972).

\subsubsection{PARA A ODONTOLOGIA}

> Representa uma nova área de especialidade, abrindo um mercado de trabalho para os cirurgiões-dentistas.

> A odontologia passa a contribuir e a assumir a sua parcela de responsabilidade social com relação à saúde dos trabalhadores.

> A odontologia assume, juntamente com outras profissões de saúde, a responsabilidade pela aumento da estabilidade industrial, da produtividade e da segurança (Goldhorn, 1947).

\subsection{POLÍTICA DE SAÚdE DA EMPRESA E POLÍTICA DE ODONTOLOGIA EM SAÚDE DO TRABALHADOR NA EMPRESA}

Thomas (1918) escreve que o corpo humano é a mais maravilhoso mecanismo já criado, e que maior atenção, portanto, deve ser dada ao seu cuidado e bem-estar. Enfatiza que a adoção de uma política de saúde na empresa traz benefícios para todos. 
Com base em Leavell \& Clark (Leavell \& Clark, 1976; Gonçalves, 1988), a "história natural da doença humana" pode ser descrita em três fases: uma fase pré-patogênica - que pode ser dividida em inespecífica e específica -, a fase clínica - dividida em precoce e avançada - e as seqüelas.

De acordo com Mendes (1980) "existe, na verdade, uma constante batalha por parte do homem para manter um saldo positivo contra as forças biológicas, físicas, mentais e sociais que tendem a alterar o equilíbrio de sua saúde”. O processo saúde-doença é resultado da interação de múltiplos fatores causais, e um modelo para representá-lo é o do "triângulo epidemiológico" cujos vértices, em equilíbrio dinâmico, são o agente, o meio ambiente e o hospedeiro (Figura 11).

O agente patogênico é um elemento que, em presença ou ausência, pode desencadear, em um hospedeiro susceptível e com meio ambiente favorável, um processo patogênico. Pode ser um agente físico, químico, biológico ou mecânico. O meio ambiente compreende o ambiente físico (clima, estação, tempo etc.), o ambiente biológico e o ambiente social e econômico. O hospedeiro deve ser considerado quanto a hábitos, costumes, idade, sexo, grupo étnico, estado civil, ocupação, além de fatores intrínsecos como o genótipo (carga genética) e os mecanismos de defesa, que são os fatores que contribuem na definição do rumo do processo saúde-doença (Mendes, 1980).

Considerando que a doença e os acidentes do trabalho são resultados da interação de vários fatores sobre o trabalhador, é possível 
criar barreiras de proteção de níveis de complexidade crescente, adaptados às diferentes fases da história natural da doença humana.

No 1ำ nível temos a Promoção de Saúde, na qual se desenvolve um conjunto de ações sobre o meio ambiente e sobre o trabalhador, por meio de informações educativas que objetivam aumentar a saúde e o bem-estar geral.

As barreiras de $2^{\circ}$ nível são denominadas de Proteção Específica, e correspondem a um conjunto de ações que visam evitar doenças cujos fatores causais são conhecidos, ou atenuar suas conseqüências.

As de $3^{\circ}$ nível, ou Diagnóstico e Tratamento Precoce ou Imediato de doenças já em curso, têm o objetivo de evitar a contaminação de terceiros. Se a moléstia for transmissível, curar ou estacionar seu processo evolutivo, a fim de evitar seqüelas e a invalidez prolongada (Leavell \& Clark, 1976).

Já as de 4º nível - Limitação da Incapacidade ou do Dano - visam a limitação do dano causado pela doença com o tratamento do processo patológico mais ou menos avançado, e as de $5^{0}$ nível - também chamadas de Reabilitação - objetivam dotar o trabalhador de meios para superar as seqüelas da doença, permitindo a reabilitação física e mental do indivíduo e reintegrando-o na sociedade (Gonçalves, 1988).

De acordo com Gonçalves (1988), para melhor entendimento, essas fases foram primeiramente denominadas prevenção primária, secundária e terciária, e depois foram agrupadas em conjuntos, com a nomenclatura promoção, proteção e recuperação da saúde. 
Chaves (1986) relata que, como a medicina, a odontologia acostumou-se a usar as expressões odontologia preventiva e odontologia curativa, assistencial ou reparadora. A ênfase predominante da odontologia foi, por muito tempo, a cura e a reparação, e somente

“pouco a pouco as idéias e princípios básicos da odontologia preventiva vão sendo incorporados e recebendo ênfase nos cursos de formação profissional". "A dicotomia da medicina e da odontologia, em uma fase preventiva e uma fase curativa, tem sido em geral associada na prática a um conceito também dicotomizado do exercício profissional".

As atividades preventiva e curativa da odontologia são validadas no âmbito político e social da comunidade, e podem servir tanto para o governo - como norteadoras de medidas a serem adotadas -, quanto para a empresa - que é o local onde o trabalhador se insere em um grupo profissional.

Para Gonçalves (1988), a empresa é uma entidade econômica porque visa produzir resultados econômicos, suprindo a comunidade de bens e de serviços e mantendo ou aumentado as riquezas a partir dos recursos econômicos e materiais. Mas também é uma entidade humana e social, pois nasce de uma iniciativa de homens por meio da qual reúne, em sua estrutura, pessoas e coisas estéreis que se tornam produtivas pela ação das pessoas. 


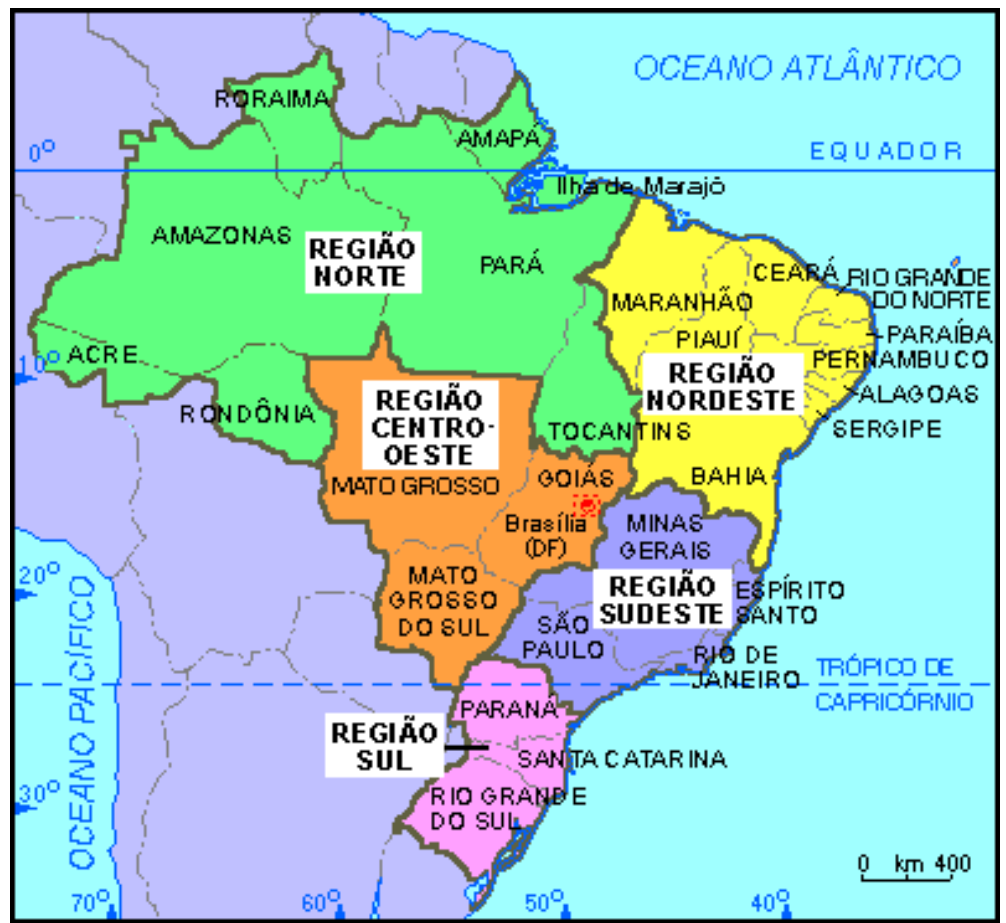

Figura 10 - Mapa político da República Federativa do Brasil.

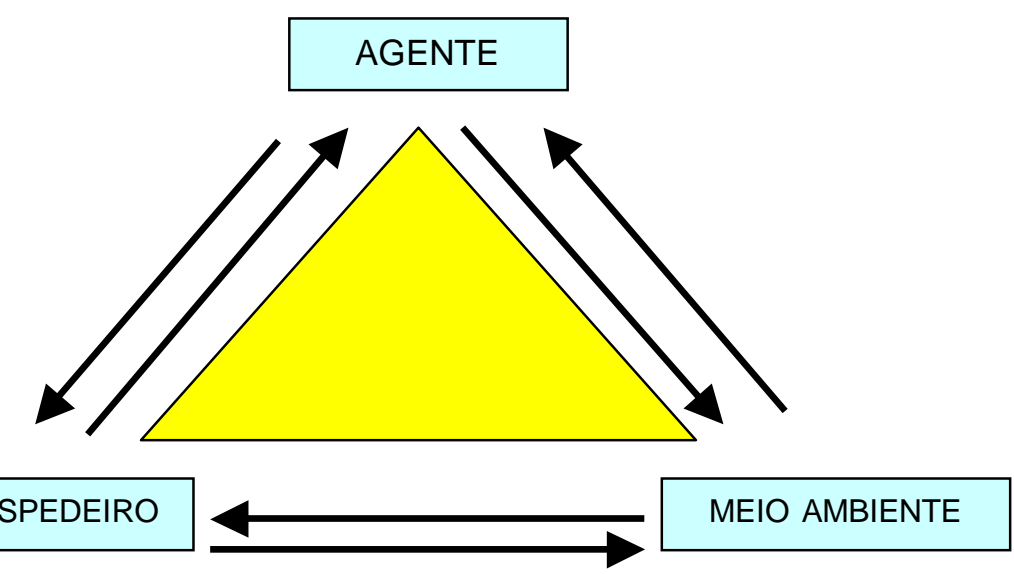

Figura 11 - Triângulo Epidemiológico. 
A abordagem dos problemas de saúde dos trabalhadores pode ser analisada de forma análoga à análise de saúde voltada à comunidade. Deve se desenvolver uma mentalidade de odontologia que englobe tanto as atividades de odontologia em saúde do trabalhador como as atividades assistenciais. Assim, será possível visualizar iniciativas e funções que, apesar de desenvolvidas em diferentes órgãos profissionais visam um bem comum, que é a saúde dos trabalhadores.

A implantação de uma política de odontologia em saúde do trabalhador deve estar integrada à política de saúde do trabalhador da empresa.

\begin{tabular}{|c|c|c|c|c|c|}
\hline \multicolumn{6}{|c|}{ História Natural da Doença Humana } \\
\hline \multicolumn{2}{|c|}{ Pré-patogênese } & \multicolumn{3}{|c|}{ Fase Clínica } & \multirow{2}{*}{ Seqüelas } \\
\hline Inespecífica & Específica & \multicolumn{2}{|c|}{ Precoce } & Avançada & \\
\hline 1ํonível & 2º nível & \multicolumn{2}{|c|}{ 3onivel } & 4ํnível & 5o nível \\
\hline $\begin{array}{l}\text { Promoção de } \\
\text { Saúde }\end{array}$ & $\begin{array}{l}\text { Proteção } \\
\text { Específica }\end{array}$ & \multicolumn{2}{|c|}{$\begin{array}{l}\text { Diagnóstico e } \\
\text { Tratamento } \\
\text { Precoce }\end{array}$} & $\begin{array}{l}\text { Limitação do } \\
\text { Dano }\end{array}$ & Reabilitação \\
\hline \multicolumn{2}{|c|}{ Prevenção Primária } & \multicolumn{2}{|c|}{$\begin{array}{l}\text { Prevenção } \\
\text { Secundária }\end{array}$} & \multicolumn{2}{|c|}{ Prevenção Terciária } \\
\hline $\begin{array}{l}\text { Promoção de } \\
\text { Saúde }\end{array}$ & $\begin{array}{l}\text { Proteção da } \\
\text { Saúde }\end{array}$ & \multicolumn{4}{|c|}{ Recuperação da Saúde } \\
\hline \multicolumn{2}{|c|}{ Odontologia Preventiva } & \multicolumn{4}{|c|}{ Odontologia Curativa } \\
\hline \multicolumn{3}{|c|}{ Odontologia em Saúde do Trabalhador } & & \multicolumn{2}{|c|}{ Odontologia Assistencial } \\
\hline \multicolumn{6}{|c|}{ Odontologia } \\
\hline
\end{tabular}

Figura 12 - História natural e possíveis barreiras à doença humana 


\subsection{FUNÇÕES DO CIRURGIÃO-DENTISTA DO TRABALHO}

Neste item procuraremos fornecer uma visão abrangente dos aspectos a serem considerados nas diferentes atividades do cirurgiãodentista do trabalho.

As funções do Serviço de Odontologia em Saúde do Trabalhador integrante do Serviço Especializado em Segurança e Saúde no Trabalho da empresa -, serão abordadas de forma sucinta, pois cada uma delas, de per si, pode ser tomada como tema e ser desenvolvida com mais profundidade.

Com base na filosofia da saúde do trabalhador, tais funções podem ser desenvolvidas de acordo com as características da empresa, de sua política de saúde e do interesse do profissional.

\subsubsection{ORGANIZAÇÃO DO SERVIÇO DE ODONTOLOGIA EM SAÚDE DO TRABALHADOR NA EMPRESA}

Já que não existe a possibilidade de presenciarmos uma boca andando sozinha ou um indivíduo andando sem a boca, não podemos falar que uma pessoa tem "saúde" sem levar em consideração a saúde bucal. Isto porque estamos diante de uma via de mão dupla: a saúde geral influencia a saúde bucal, e a saúde bucal influencia a saúde geral. Da mesma forma, não se pode imaginar um serviço de Saúde do Trabalhador, na empresa ou na área pública, sem a odontologia presente. 
A organização de um Serviço de Odontologia em Saúde do Trabalhador na empresa começa com a política de saúde da empresa, pois o sucesso ou fracasso desse serviço está intimamente relacionado ao valor que a empresa dá aos seus colaboradores (trabalhadores).

Segundo Dias (2000), é

"cada vez mais difícil falar de um mundo do trabalho que pertence à esfera da fábrica ou da produção, e um mundo fora do trabalho. É igualmente difícil definir com clareza quem são os trabalhadores. De quem estamos falando? O mundo é um só e os trabalhadores transformam e são transformados, com um modo de viver que é determinado historicamente, definido socialmente $e$ diferenciado em classes sociais."

Para planejar um serviço que intervenha na saúde dos trabalhadores deve-se levar em consideração o processo de produção e sua reestruturação, as mudanças urbanas, a organização do trabalho, os fatores de risco industriais e ambientais e a saúde mental do trabalhador.

Compreendendo como vivem, adoecem e morrem os trabalhadores, analisando sua interação com o meio ambiente, e com base na legislação internacional e nacional sobre saúde do trabalhador, podemos organizar melhor o serviço odontológico de saúde do trabalhador na empresa.

A legislação internacional sobre o assunto tem seu início em 1959, quando a Organização Internacional do Trabalho (OIT, 2000a) adotou a Recomendação no 112 - Recomendação sobre os Serviços de Medicina do Trabalho nos locais de trabalho - que inspirou os países membros a criarem instrumentos legais para obrigar a criação e a manutenção dos serviços de saúde nas empresas (Anexo 1).

Essa Recomendação definiu que o serviço tinha como objetivo 
"garantir a proteção dos trabalhadores contra todo o risco que prejudique a sua saúde e que possa resultar de seu trabalho ou das condições em que este se efetue; a contribuir na adaptação física e mental dos trabalhadores em particular pela adequação do trabalho aos trabalhadores e por sua colocação em postos de trabalho correspondentes a suas aptidões; $e$, a contribuir ao estabelecimento e manutenção do nível mais elevado possível de bem estar físico e mental dos trabalhadores".

Em 1985 a OIT adotou o Convênio no 161 (Convênio sobre os Serviços de Saúde do Trabalho) (Anexo 2) e a Recomendação no 171 (Recomendação sobre os Serviços de Saúde do Trabalho) (Anexo 3), que substituíram a Recomendação oํ 112 sobre os Serviços de Saúde no Trabalho (SST). Nesses documentos aquela organização enfatiza a multidisciplinaridade na aplicação do conceito de segurança e higiene do trabalho.

Os "Serviços de Saúde no Trabalho devem estar orientados, essencialmente, para as ações preventivas, aconselhando empregados e empregadores no sentido de se buscar um ambiente e condições de trabalho seguro e salubre, favorecendo a saúde física e mental, adaptando o trabalho à capacidade e condições dos trabalhadores" (OIT, 2000b).

O artigo 5ำ da Convênio nำ161 aponta as seguintes funções para o

Serviço de Saúde no Trabalho (OIT, 2000b):

a) “identificação e avaliação dos riscos que possam prejudicar a saúde no local de trabalho;

b) vigilância dos fatores do meio ambiente e das práticas de trabalho que possam afetar a saúde dos trabalhadores, incluídas as instalações sanitárias, restaurantes e alojamentos, quando estas facilidades sejam proporcionadas pelo empregador;

c) assessoramento sobre o planejamento e a organização do trabalho, incluído o desenho dos locais de trabalho, sobre a seleção, a manutenção e o estado das máquinas e dos equipamentos e sobre as substâncias utilizadas no trabalho;

d) participação no desenvolvimento de programas para o melhoramento das práticas de trabalho, assim como nas 
provas e na avaliação de novos equipamentos, em relação com a saúde;

e) assessoramento em matéria de saúde, de segurança e de higiene no trabalho e de ergonomia, assim como em matéria de equipamentos de proteção individual e coletiva;

f) vigilância da saúde dos trabalhadores em relação com o trabalho;

g) fomento da adaptação do trabalho aos trabalhadores;

h) assistência em prol da adoção de medidas de reabilitação profissional;

i) colaboração na difusão de informações na formação $e$ educação em matéria de saúde e higiene no trabalho e de ergonomia;

j) organização dos primeiros-socorros e dos atendimentos de urgência;

k) participação na análise dos acidentes do trabalho e das doenças profissionais.”

No Brasil, com a Portaria no 3237, de 27 de junho de 1972, do Ministério do Trabalho e Previdência Social, tornou-se obrigatório que as empresas mantenham o Serviço de Medicina do Trabalho dimensionado de acordo com o grau de risco e o número de trabalhadores da empresa.

Com a Lei $n^{\circ}$ 6.514, de 22 de dezembro de 1977, alterou-se todo o Capítulo V do Título II da Consolidação das Leis do Trabalho (CLT) - relativo à Segurança e Medicina do Trabalho -, que passou a ser "Da Segurança e da Medicina do Trabalho", e o Ministério do Trabalho recebeu a competência para regular os assuntos referentes a este capítulo.

A Portaria $n^{0} 3.214$, de 8 de junho de 1978, aprovou as Normas Regulamentadoras - NR - do Capítulo V, Título II, da CLT, relativas à Segurança e Medicina do Trabalho. Originalmente as NRs eram em número de 28; no ano 2000 há 29 NRs. Nesta Portaria, a NR-4 trata dos Serviços Especializados em Segurança e Medicina do Trabalho (SESMT) (Anexo 4), 
estabelece o tipo e o número de profissionais especializados que deverão compor a equipe e classifica as empresas de acordo com o número de funcionários e o grau de risco ocupacional que oferecem.

De acordo com a NR-4 compete, aos profissionais integrantes dos Serviços Especializados em Engenharia de Segurança e em Medicina do Trabalho (Brasil, 1998):

a) aplicar os conhecimentos de Engenharia de Segurança e de Medicina do Trabalho ao ambiente de trabalho e a todos os seus componentes, inclusive máquinas e equipamentos, de modo a reduzir até eliminar os riscos ali existentes à saúde do trabalhador;

b) determinar, quando esgotados todos os meios conhecidos para a eliminação do risco e este persistir, mesmo reduzido, a utilização, pelo trabalhador, de equipamentos de proteção individual (EPI), de acordo com o que determina a NR-6, desde que a concentração, a intensidade ou característica do agente assim o exija;

c) colaborar, quando solicitado, nos projetos e na implantação de novas instalações físicas e tecnológicas da empresa, exercendo a competência disposta na alínea " $a$ ",

d) responsabilizar-se, tecnicamente, pela orientação quanto ao cumprimento do disposto nas NR aplicáveis às atividades executadas pela empresa elou seus estabelecimentos;

e) manter permanente relacionamento com a CIPA, valendo-se ao máximo de suas observações, além de apoiá-la, treiná-la e atendê-la, conforme dispõe a NR-5;

f) promover a realização de atividades de conscientização, educação e orientação dos trabalhadores para a prevenção de acidentes do trabalho e doenças ocupacionais, tanto através de campanhas, quanto de programas de duração permanente;

g) esclarecer e conscientizar os empregados sobre acidentes do trabalho e doenças ocupacionais, estimulando-os em favor da prevenção;

h) analisar e registrar em documento(s) especifico(s) todos os acidentes ocorridos na empresa ou estabelecimento, com ou sem vítima, e todos os casos de doença ocupacional, descrevendo a história e as características do acidente elou da doença ocupacional, os fatores ambientais, as características do agente e as condições do(s) indivíduo(s) portador(es) de doença ocupacional ou acidentado(s); 
i) registrar mensalmente os dados atualizados de acidentes do trabalho, doenças ocupacionais e agentes de insalubridade preenchendo, no mínimo, os quesitos descritos nos modelos de mapas constantes nos Quadros III, IV, V e VI, devendo a empresa encaminhar um mapa contendo avaliação anual dos mesmos dados à Secretaria de Segurança e Medicina do Trabalho até o dia 31 de janeiro, através do órgão regional do $M T b$;

j) manter os registros de que tratam as alíneas " $h$ e $i$ " na sede dos Serviços Especializados em Engenharia de Segurança e em Medicina do Trabalho ou facilmente alcançáveis a partir da mesma, sendo de livre escolha da empresa o método de arquivamento e recuperação desde que sejam asseguradas condições de acesso aos registros e entendimento de seu conteúdo, devendo ser guardados somente os mapas anuais dos dados correspondentes às alíneas " $h$ " $e$ " $i$ " por um período não inferior a 5 (cinco) anos;

l) as atividades dos profissionais integrantes dos Serviços Especializados em Engenharia de Segurança e em Medicina do Trabalho são essencialmente prevencionistas, embora não seja vedado o atendimento de emergência, quando se torna necessário. Entretanto, a elaboração de planos de controle de efeitos de catástrofes, de disponibilidade de meios que visem ao combate a incêndios e ao salvamento e de imediata atenção à vítima deste ou de qualquer outro tipo de acidente estão incluídos em suas atividades.

Recentemente houve a publicação no Diário Oficial, para consulta pública, da Portaria oํ 10, de 6 de abril de 2000, que trata da proposta para alteração da NR 4 - Serviço Especializado em Engenharia de Segurança e Medicina do Trabalho - SESMT (Anexo 6)(Brasil, 2000b).

Essa Portaria propõe um Sistema Integrado de Prevenção de Riscos

\section{do Trabalho (SPRT) que}

"consiste no conjunto permanente de ações, medidas e programas, previstos em normas e regulamentos, além daqueles desenvolvidos por livre iniciativa da empresa, tendo como objetivo a prevenção de acidentes e doenças, de modo a tornar compativel permanentemente o trabalho com a preservação da vida, a promoção da saúde do trabalhador e do meio ambiente de trabalho". 
As ações de prevenção de acidentes e doenças do trabalho devem integrar-se ao processo produtivo, abrangendo todos os aspectos relacionados ao trabalho e o planejamento das ações de prevenção, por meio da implementação dos programas de gestão de segurança e saúde do trabalhador, da participação dos trabalhadores no planejamento, da execução e avaliação das medidas adotadas pela empresa e do emprego de técnicas atualizadas de prevenção.

E propõe a formação do Serviço Especializado em Segurança e Saúde no Trabalho (SEST), que será "um serviço especializado constituído por uma unidade organizada e integrada, composta por profissionais dedicados exclusivamente ao cumprimento de atribuições relacionadas à prevenção de riscos laborais" e permitirá a inclusão de outros profissionais especializados, por meio de convenção coletiva ou por determinação estratégica da empresa.

Com base nessas diretrizes e na política de saúde da empresa, o cirurgião-dentista do trabalho irá organizar o Serviço de Odontologia em Saúde do Trabalhador na empresa.

De acordo com o número de funcionários, a modalidade de acesso à assistência odontológica (serviços próprios; serviços contratados externamente como odontologia de grupo, cooperativa odontológica e seguradora; serviços institucionais Serviço Social do Comércio (SESC) /Serviço Social da Industria (SESI) /Serviço Social da Construção Civil (SECONCI) /sindicatos e serviços públicos) e objetivos do SESMT, o cirurgião-dentista do trabalho dimensionará o serviço, a localização, os profissionais necessários para formar a equipe de saúde bucal - cirurgião- 
dentista, técnico em higiene dental, atendente de consultório dentário (CD, THD e ACD) -, o sistema de trabalho etc.

Não existe uma melhor maneira de organizar um tipo de serviço como este, pois vários fatores influenciam suas atividades, sendo necessário um maior aprofundamento no tema.

Através da legislação em vigor referente ao SESMT, e pela revista da literatura, constatamos que as funções que o cirurgião-dentista do trabalho pode desempenhar são:

> Realizar o censo odontológico e a vigilância epidemiológica;

> Conhecer o local de trabalho, o processo de fabricação e as funções dos empregados;

> Participar dos levantamentos de campo para análise profissiográfica;

> Participar dos programas de ergonomia da empresa;

> Realizar exames odontológicos e o manter o prontuário de odontologia em saúde do trabalhador;

> Supervisionar as facilidades de treinamento de primeiros-socorros e normas de segurança;

> Coordenar o programa de saúde bucal da empresa (odontologia preventiva, educação em saúde bucal e promoção de saúde) e as atividades de prevenção, diagnóstico e tratamento dos acidentes de trabalho e das doenças profissionais;

> Empreender atividades de odontologia restauradora, curativa ou assistencial;

> Participar da Comissão Interna de Prevenção de Acidentes (CIPA);

> Aconselhar a gerência da empresa em todo assunto relacionado à saúde do trabalhador;

> Proceder à avaliação e/ou auditoria no campo da odontologia; e, 
> Participar de perícia, no campo da odontologia em saúde do trabalhador, na qualidade de perito do juízo ou assistente técnico.

\subsubsection{Censo Odontológico e Vigilância Epidemiológica}

O Censo Odontológico tem como objetivo registrar as condições de saúde bucal dos trabalhadores para o planejamento de programas de atenção à saúde bucal, levantar dados para gerenciamento do relacionamento com a assistência odontológica (autogestão, odontologia de grupo, seguradora etc.), promover a preparação para exames periódicos etc. (Guimarães \& Rocha, 1979c);

O Censo Odontológico pode ser dividido em:

- Diagnóstico da situação

- Estudo Epidemiológico

- Estabelecimento de Prioridades

- Atendimento das Prioridades

No diagnóstico da situação, adaptado de Pinto (1996), procura-se conhecer a população que será beneficiada respondendo, por exemplo às seguintes questões:

- Qual é a população de trabalhadores da empresa, como vivem, quais são suas características sócio-econômicas;

- Qual é a área de abrangência do programa;

- Quem possui assistência odontológica e quem fará parte da clientela de serviços curativos e/ou preventivos; 
- Qual é a oferta de serviços odontológicos em termos de profissionais disponíveis, os trabalhadores têm a eles;

- Que outras entidades e instituições prestam atenção odontológica aos trabalhadores;

- Qual é o quadro epidemiológico de saúde bucal da empresa;

- Como os trabalhadores encaram a própria saúde bucal;

- Áreas e focos de resistência ao desenvolvimento do programa;

- Parcerias possíveis.

No estudo epidemiológico, os levantamentos epidemiológicos em saúde bucal "são utilizados para coletarmos informações acerca da condição de saúde bucal e das necessidades de tratamento de uma população, e, subseqüentemente, para monitorarmos as alterações nos níveis e padrões de doenças" (OMS, 1999).

Utilizando uma ficha padronizada, por exemplo a da OMS (1999) verifica-se, ao exame clínico, a condição extra-bucal, a situação da articulação temporomandibular, da mucosa bucal, as opacidades de esmalte/hipoplasia, a fluorose dentária, os índices de cárie, índice de superfícies de dentes cariados, perdidos ou obturados (CPO-S), os dentes isentos de cárie, os índices periodontais como o índice comunitário de necessidade de tratamento periodontal (CPITN) ou o periodontal screening \& recording system (PSR), a necessidades e utilização de prótese total, as anomalias dentofaciais e a necessidade de tratamento imediato e encaminhamento (Anexo 7).

Após a análise estatística e qualitativa dos dados procede-se ao Estabelecimento de Prioridades, pois na maior parte das vezes os recursos 
para eliminar todos os problemas da população trabalhadora da empresa são escassos ou limitados. O Estabelecimento de Prioridades nada mais é do que o momento em que são eleitos os problemas que receberão maior ênfase e recursos do programa durante um determinado tempo.

Guimarães e Rocha (1979c) classificam as prioridades da seguinte forma:

- 1ํgrau: casos que apresentarem lesões nos tecidos moles e duros com aspectos ou tendências malignas.

- 2ํㅡㅁau: casos que apresentarem focos de origem dentária e periodontais, com conseqüências locais e gerais.

- 3o grau: casos que apresentarem cáries dentárias e problemas periodontais.

- 4ํgrau: casos que apresentarem ausências dentárias com comprometimento estético-funcional.

E, por fim, chega-se à programação do Atendimento das Prioridades, fase em que se determinará a ordem das prioridades e, conforme o exemplo acima, pode ser adaptada de Guimarães \& Rocha (1979c):

- $1^{\circ}$ grau: encaminhadas aos órgãos especializados para confirmação de diagnóstico e tratamento;

- $2^{\circ}$ grau, $3^{\circ}$ grau e $4^{\circ}$ grau: serão atendidas ou encaminhadas até a sua conclusão, dependendo do tipo de sistema de assistência odontológica mantido pela empresa.

Concordamos com Caetano \& Watanabe (1994), Pinto (1996) e Moysés (1997) sobre o auxílio que o censo odontológico pode trazer para a estimativa a prevalência das doenças bucais; a previsão de custos e de 
recursos materiais e humanos nas fases de implantação, manutenção e expansão dos programas odontológicos. O censo também ajuda a estabelecer a natureza e a dimensão dos serviços curativos, preventivos e educativos necessários, e a estabelecer as prioridades do programa, proporcionando dados de referência para as avaliações deste, e uma das formas de coleta de dados é a realização de levantamentos periódicos, baseados em pequenas amostras dos trabalhadores.

\subsubsection{LoCal de tRabalHo, PROCesso de fabricação E funções dos EMPREGADOS}

O Comitê de Economia da ADA (1942) publicou a proposta de um "Mínimo Padrão para Serviço Odontológico na Indústria”, na qual preconiza que o cirurgião-dentista industrial deve estar familiarizado com os processos industriais e estar atento às evidências de manifestações bucais de doenças profissionais.

Adaptando o item 15 da Recomendação oํ 112, também o CD do trabalho deve "gozar de independência profissional e moral completa em relação ao empregador e aos seus trabalhadores". No item 20 essa recomendação postula que o serviço deve:

a) "ter livre acesso a todas as instalações auxiliares da empresa e a todos os lugares de trabalho;

b) visitar os locais de trabalho em intervalos adequados, em colaboração, se necessário, com outros serviços da empresa;

c) ser informado sobre os procedimentos empregados, as normas de trabalho e as substâncias utilizadas ou cuja utilização está prevista; 
d) ter a possibilidade de efetuar, ou de solicitar que se efetuem por organismos técnicos reconhecidos:

i) averiguações e investigações sobre riscos profissionais que podem ameaçar a saúde; por exemplo, mediante colheita de amostras e análises da atmosfera dos locais de trabalho, dos produtos e das substâncias utilizadas de qualquer outra matéria de suposta nocividade;

ii) controle de agentes físicos prejudiciais.

e) ter a possibilidade de pedir às autoridades competentes que fiscalizem o cumprimento das normas de higiene $e$ de segurança no trabalho".

Concordamos com Guimarães \& Rocha (1979a) que recomendam, ao cirurgião-dentista do trabalho, que conheça os locais de trabalho da empresa, o processo de produção e a ocupação real dos trabalhadores, pois essas informações Ihe permitirão avaliar a nocividade, os riscos de acidentes de trabalho e as doenças profissionais a que o grupo está exposto, em especial aqueles que podem ter reflexos sobre a saúde bucal, fazendo com que os programa odontológicos preventivos sejam adequados à empresa.

O conhecimento da atividade real desempenhada, do local de trabalho, do processo tecnológico e das matérias-primas manipuladas propicia uma melhor visão da atividade desempenhada pelo trabalhador e o reconhecimento de sinais e sintomas que podem se manifestar na cavidade bucal quando da realização dos exames admissionais e periódicos, ampliando a probabilidade de diagnóstico - ou pelo menos a suspeita - de doenças profissionais.

\subsubsection{Levantamentos de campo para Análise Profissiográfica}

A análise profissiográfica, segundo Rocha et al. (1979) e Guimarães e Rocha (1979c), é um método que visa conhecer os tipos de trabalho 
existentes na empresa, as exigências morfofisiopsicológicas para o desempenho adequado de cada uma delas, e subsidiar o departamento de $\mathrm{RH}$ na preparação de processos de recrutamento e seleção, classificação de cargos e salários e treinamento.

Além disso, esse instrumento possibilita a identificação de pontos críticos da rotina de trabalho e seus riscos ambientais, contribuindo subsídios para o estabelecimento de medidas de adequação de postos de trabalho, máquinas e ferramentas (ergonomia), e de medidas preventivas de segurança contra acidentes de trabalho. Também permite que o exame préadmissional seja calcado em requisitos específicos para cada cargo, de forma a que a seleção seja mais técnica e integrada com as outras áreas que compõem a saúde do trabalhador.

A ficha profissiográfica - também chamada ficha de especificação - é um resumo da análise profissiográfica. Contém as informações: análise do cargo, requisição dos empregados, e elenca as aptidões, habilidades e personalidade necessárias para exercer o cargo (Chiavenato, 1995; Carvalho \& Nascimento, 1997).

Para Carvalho \& Nascimento (1997) - dentre as vantagens da ficha profissiográfica - podem ser citadas a descrição resumida e atualizada das aptidões, habilidades e traços da personalidade do ocupante do cargo; a listagem das características sociais exigidas para o pleno exercício das funções que compõem o cargo a ser preenchido; e as responsabilidades inerentes ao cargo. E seus objetivos são: selecionar o candidato mais 
adequado para o cargo, reduzir os riscos de acidentes de trabalho e preservar a saúde do trabalhador.

Para que essa análise seja a mais completa possível, deve ser realizada por uma equipe interprofissional (Rocha et al., 1979; Guimarães \& Rocha, 1979c). O médico do trabalho, o engenheiro de segurança do trabalho, o psicólogo, o assistente social, o administrador da empresa e o cirurgião-dentista do trabalho têm que, dentro de suas área específicas de conhecimento, levantar os obstáculos de cada cargo e, juntos, procurar elaborar o perfil profissiográfico.

Não podemos esquecer que esse trabalho deve sempre ser norteado pela premissa da ergonomia, que propõe que os sistemas de produção sejam desenvolvidos com a participação de todos os atores sociais da produção, buscando a adaptação do trabalho ao homem e elevando a produtividade com qualidade e com saúde do trabalhador.

A função do cirurgião-dentista do trabalho nessa equipe é a de desenvolver, de acordo com os cargos da empresa, um critério de exigências odontológicas compatível com o cargo e suas atribuições, funções e exposição social.

Assim, nos processos de seleção e de recolocação do trabalhador, será possível avaliar as aptidões físicas e emocionais de cada indivíduo, procurando mantê-lo dentro dos limites exigidos para o exercício do cargo através dos exames odontológicos, e providenciando que as exigências sejam cumpridas sempre que necessário. 


\subsubsection{PARTICIPAÇão NOS PROGRAMAS de ERGONOMIA DA EMPRESA}

Com relação à ergonomia, Mascia \& Sznelwar (1997) relatam que a aplicação de conhecimentos parciais e empíricos aos problemas do trabalho iniciou-se com a criação das primeiras ferramentas, nos primórdios da história da humanidade, quando as formas e dimensões eram definidas pelo material utilizado, os resultados esperados e as características dos homens que as utilizavam.

Nos séculos XVII e XVIII, Valban e Belidor mediram a carga física do trabalho; outros físicos e fisiologistas estudaram o homem em atividade, tentando compreender o seu funcionamento. Na obra "O Motor Humano", Jules Amar, no início do século XX, apresentou as bases da ergonomia. Após a 2a Guerra Mundial, a engenharia humana aplicada durante a guerra foi estendida à área industrial para melhorar as condições de vida dos trabalhadores e aumentar a produtividade (Mascia \& Sznelwar, 1997).

Em 1949, o inglês Murell definiu ergonomia (das palavras gregas: ergon $=$ trabalho e nomus $=$ lei) na recém-criada Ergonomic Research Society. O termo ergonomia foi utilizado, pela primeira vez, por Jastrzerbowski, que definiu-o como a ciência da utilização das forças e capacidades humanas.

Para Murell, ergonomia é o "estudo do relacionamento entre o homem e o seu trabalho, equipamento e ambiente, e particularmente a aplicação dos conhecimentos de anatomia, fisiologia e psicologia na solução dos problemas surgidos desse relacionamentos" (lida, 1993). 
Em 1983, Grandjean conceitua ergonomia como "o estudo do comportamento do homem no seu trabalho", convertendo-se o mesmo homem no sujeito-objeto de seu estudo "das relações entre o homem no trabalho e seu ambiente" (Rio \& Pires, 1999).

E, para Wisner (1987), ergonomia é o "conjunto de conhecimentos relativos ao homem e necessários à concepção de ferramentas, máquinas e dispositivos que possam ser utilizados com o máximo de conforto, segurança e eficácia".

Existem hoje duas abordagens da ergonomia. A primeira, dominante em países anglo-saxônicos e no Japão, privilegia a interface entre os componentes materiais e os fatores humanos, levando em conta as características antropométricas dos indivíduos, o esforço físico, o ambiente físico, as características psicofisiológicas, os ritmos circadianos, o envelhecimento etc. As dessa linha são realizadas com métodos experimentais, em laboratório.

A segunda abordagem surgiu na França e na Bélgica, e enfatiza a dinâmica da atividade humana no trabalho. O trabalho é analisado como um processo no qual interagem o trabalhador - capaz de iniciativas e reações -, e o seu ambiente técnico. Nessa linha, os pesquisadores deixam os laboratórios e analisam o trabalho em campo, buscando conhecer sua real situação.

A globalização da economia, segundo Rio \& Pires (1999), trouxe para a ergonomia novas situações desafiadoras, como as exigências de produtividade e desempenho, que exigem que as concepções e práticas 
estejam de acordo com a saúde e a produtividade. Novas situações ocorrem, com a falta de exercício físico - que exige redução da carga física -, e o estresse psíquico decorrente sa intensificação do trabalho e da própria globalização.

O Método de Análise Ergonômica do Trabalho, segundo Guerrin et al. (apud Mascia \& Sznelwar, 1997), tem as características de um diagnóstico clínico, construído a partir de diferentes conhecimentos; inicia-se com uma demanda (Análise da Solicitação Inicial), que indica em que nível da organização se situa o problema, a origem dessa demanda, os problemas, as perspectivas de ação e os meios disponíveis para implementá-las.

A seguir, deve-se delimitar um sistema, ou seja, uma situação de trabalho com os seguintes elementos: a empresa, o sistema sóciotécnico, a população envolvida, a situação de trabalho (Análise dos Fatores Organizacionais, Técnicos e Econômicos).

Para o próximo passo (Análise da Tarefa), é necessário delimitar as exigências da tarefa prescrita pela organização. É necessário conhecer parâmetros como objetivos, procedimentos, meios técnicos, meios humanos, ambiente físico, condições temporais e condições sociais, cujas interrelações permitem identificar as exigências e os constrangimentos da tarefa, compreendendo as regulações individuais e coletivas existentes no ambiente de trabalho.

A Análise da Atividade compreende a coleta de informações com os instrumentos de observação definidos pelos operadores, e as condições 
materiais de seu uso. Nessa etapa, as anotações são mais eficientes que o uso de gravadores e/ou filmagens.

Também podem ser utilizados entrevistas, questionários e documentos formais e informais. A participação dos trabalhadores é importante, pois estes conhecem a situação de trabalho, suas anomalias e os riscos apresenta à sua saúde. Após os resultados da análise, as Propostas de Soluções devem ser validadas com os trabalhadores e os empresários.

A seguir procede-se à Implementação das Soluções e à Avaliação da Intervenção, para verificar se houve melhora das condições de trabalho dentro dos limites considerados aceitáveis para a produção; nesse momento, a avaliação trabalhadores/usuários é adotada como um parâmetro.

Os objetivos da aplicação da ergonomia são o conforto e a saúde do trabalhador e a diminuição dos riscos de acidentes de trabalho e de doenças profissionais e do trabalho. Assim, Mascia \& Sznelwar (1997) comentam que

a

"eficácia na utilização de um produto ou de uma operação de um sistema de produção que pode ser comprometida por exigências inadequadas ou excessivas das funções humanas. Desta forma, seguindo estes passos da metodologia de análise ergonômica do trabalho podemos melhorar o posto de trabalho e preservar a saúde dos trabalhadores."

O cirurgião-dentista do trabalho deve ter noções de ergonomia para, junto com a equipe de saúde do trabalhador, ser capaz de detectar as situações de risco de acidentes e de doenças profissionais ou do trabalho, principalmente aquelas que podem atingir ou se manifestar na cavidade 
bucal, e propor soluções ou solicitar a análise de um especialista em ergonomia.

\subsubsection{Os Exames odontológicos e o Prontuário em Odontologia em SaÚde do TrabalHador}

Pela NR-7, o Programa de Controle Médico de Saúde Ocupacional (PMSO) tem como objetivo a "prevenção, rastreamento e diagnóstico precoce dos agravos à saúde relacionado ao trabalho, inclusive de natureza subclínica, além da constatação da existência de casos de doenças profissionais ou danos irreversíveis à saúde dos trabalhadores". Ao lado dos exames médicos podemos incluir os exames odontológicos, que são complementares aos exames médicos e estão incluídos no objetivo do PCMSO.

Os exames odontológicos também podem ser do tipo:

> Pré-admissional;

$>$ Periódico;

$>$ Demissional;

> Mudança de função;

> Retorno ao trabalho;

O exame odontológico pré-admissional é aquele realizado antes que o trabalhador assuma as suas atividades, e tem como objetivos:

> proteger os futuros empregados de trabalho para o qual não estejam fisicamente qualificados, detectar doenças em fase inicial, e proteger os empregados da companhia de doenças contagiosas (Thomas, 1918); 
> diagnosticar as enfermidades bucais e sistêmicas manifestadas na cavidade oral;

detectar estados mórbidos que contra-indiquem o candidato à função temporária ou permanentemente.

O empregador pode requerer que os problemas odontológicos mais graves sejam tratados antes da admissão do empregado ou, caso o empregado não tenha recursos, pode ser estabelecido um prazo limite para a realização do tratamento após a sua admissão (Walls \& Bethlehem, 1942).

Guimarães \& Rocha (1979b) citam um elenco exigências odontológicas escalonado de 1 a 4 , da menor para a maior necessidade de saúde bucal que a função requer. No patamar de exigência 4 as boas condições bucais são muito significativas - destina-se aos empregados do primeiro escalão (diretor, gerente etc.) e de nível superior; na exigência 3 a saúde bucal é muito significativa, com exigência 3 para chefias - destina-se às chefias e/ou profissionais que lidem diretamente com o público; no grau de exigência 2 a saúde bucal significativa - destina-se aos demais cargos, que não têm contato com o público; na exigência 1, as boas condições bucais são levemente significativas - destina-se aos trabalhadores braçais contratado para tarefas específicas e por tempo limitado.

A aeronáutica brasileira exige um mínimo de quatro molares naturais, um em cada meia arcada. Para os candidatos a aviadores que tenham ausência de dentes naturais, as próteses só são aceitas se estiverem estética e funcionalmente satisfatórias (Ferreira, 1997). Cada empresa pode fazer uma escala de exigências, e dar um prazo ao candidato 
para sanar os problemas odontológicos antes da admissão, ou exigir que ele se comprometa a fazê-lo após a admissão.

A contra-indicação permanente (inaptidão) só é indicada quando a função apresentar riscos de agravar a anormalidade diagnosticada pelo exame do candidato, quando o candidato não aceitar as condições de tratamento ou quando não colaborar com as medidas de higiene para a recuperação da saúde.

O exame odontológico periódico é realizado em intervalos de 6 ou 12 meses - de acordo com a legislação vigente -, com base nos riscos e no número de empregados da empresa, e tem como objetivos:

> prevenir e diagnosticar doenças profissionais;

$>$ corrigir defeitos pequenos;

$>$ detectar doenças em seu estágio incipiente;

> encorajar o tratamento, quando da suspeita de problemas sérios, e recomendar o tratamento, quando negligenciado pelo trabalhador (Thomas, 1918; Guimarães \& Rocha, 1979c);

$>$ diagnosticar precocemente alterações da saúde bucal e/ou sistêmica cuja causa pode ser determinada ou agravada pelo trabalho;

$>$ investigar e adotar medidas de controle e/ou eliminação de riscos para a saúde;

> rever, avaliar e modificar os programas de saúde e o sistema assistencial;

$>$ subsidiar o planejamento do atendimento das necessidades acumuladas no período. 
Deve ser realizado um exame acurado, com radiografias periapicais e procedimentos de profilaxia, aplicação de flúor, higiene bucal, e encaminhamento para tratamento, se necessário.

O exame odontológico de retorno ao trabalho é realizado, como manda a legislação, obrigatoriamente no primeiro dia em que o trabalhador ausente por 30 ou mais dias por motivo de doença ou acidente - de natureza ocupacional ou não -, ou em decorrência de parto, retorna ao trabalho.

O exame odontológico de mudança de função é obrigatório antes da mudança de função do trabalhador, se essa alteração de atividade, posto de trabalho ou de setor implicar a exposição do trabalhador a riscos diferentes daqueles a que estava exposto anteriormente.

O exame odontológico demissional deve ser realizado obrigatoriamente até a data da homologação.

O prontuário em odontologia em saúde do trabalhador deve ser o mais completo registro da saúde bucal do trabalhador, desde sua entrada na empresa até a sua saída e, apesar de não apresentar uma forma única, deve possuir algumas características mínimas.

No Anexo 8 apresentamos uma sugestão de Prontuário em Odontologia em Saúde do Trabalhador, calcado nos conhecimentos de Diagnóstico Bucal e Odontologia Legal e adaptado às necessidades do cirurgião-dentista do trabalho.

O Prontuário em Odontologia em Saúde do Trabalhador não serve apenas para fins administrativos. Serve também para fins legais, em casos de acidentes do trabalho e de doenças profissionais e em casos processo de 
identificação de corpos em grandes acidentes de massa, pois em alguns tipos de trabalho - como aquele realizado nas petroquímicas, e aquele desempenhado pelos aviadores - as técnicas tradicionais de identificação podem não ser suficientes.

$\mathrm{Na}$ identificação do trabalhador ou dependente devem constar, por exemplo, o nome completo; o endereço residencial completo e o telefone; o endereço comercial completo e o telefone; o sexo; o estado civil; a naturalidade/nacionalidade; a data de nascimento; a profissão; a ocupação (cargo); a numeração dos documentos (RG/CPF/no funcional); se menor ou incapaz, dados dos pais ou responsável.

A seqüência da História Clínica deve contemplar

1) Pré-Anamnese

2) Queixa principal;

3) História da doença atual;

4) História buco-maxilo-facial e dental;

5) História médica;

6) Antecedentes familiares;

7) Hábitos

8) História Profissional

O Exame físico deve conter:

1) Exame extra-bucal

2) Exame intra-bucal

3) Exames complementares

4) Diagnóstico 
O Exame clínico odontológico deve ser minucioso, como enfatizam vários autores (Lostok apud Sappington, 1949; L'épée et al., 1969; Guimarães \& Rocha, 1979; Tommasi, 1988; Boraks, 1999), e deve contemplar todas as estruturas da cavidade bucal.

Deve-se começar pelo exame físico com a utilização das manobras clássicas de inspeção, auscultação, palpação, percussão, olfação, punção, diascopia, exploração, raspagem, fotografia e ordenha para examinar a fácies, as cadeias ganglionares, a articulação temporomandibular, as glândulas salivares maiores, os ossos, a musculatura e a inervação da região da cabeça e do pescoço.

O exame intra-bucal inicia-se de fora para dentro pela ordem: lábio, fundo de sulco, mucosa alveolar, gengiva inserida, gengiva livre, gengiva (papila) interdental, rebordo alveolar, mucosa jugal, língua, soalho bucal, palato duro, palato mole, porção visível da orofaringe e dentes, com a utilização de exames complementares, como radiografias periapicais, sempre que necessário.

Para a identificação dos dentes sugerimos o Sistema Decimal da Federação Dentária Internacional (FDI), em que o elemento dentário é codificado por dois números, e realização de pelo menos dois odontogramas: um destinado às condições bucais pré-admissão, e um a ser preenchido no exame demissional.

Acreditamos que a ficha odontolegal preconizada pela Disciplina de Odontologia Legal do Departamento de Odontologia Social da Faculdade de Odontologia da Universidade de São Paulo é aconselhável, pois essa ficha 
proporciona: transmissão dos dados por qualquer meio de comunicação; facilidade de preenchimento pela auxiliar; conhecimento do estado bucal anterior e posterior ao tratamento; conhecimento do material restaurador de elemento dentário; utilização plena em processos de identificação pelos dentes, e plena utilização em infornática (Silva, 1994).

Nos exames periódicos pode ser anexado um odontograma com o exame clínico e, nos casos em que assistência odontológica é prestada por empresas terceirizadas (cooperativas, odontologia de grupo, seguradoras, cirurgiões-dentistas credenciados), devem ser preenchidos odontogramas que serão enviados para atualização do prontuário do trabalhador na empresa. No caso de tratamento odontológico podem ser adotados odontogramas gráficos com figuras de dentes, para facilitar a visualização das condições bucais ao CD operacional, mas estes devem vir acompanhados de um descritivo das anotações e procedimentos.

Todos os dados obtidos nesses exames, a avaliação clínica e os exames complementares (exames médicos, radiografias), as cópias de atestados e receitas, os modelos de prótese ou outros serviços odontológicos, o comprovante de recebimento de orientação pós-operatória ou higiene bucal, as conclusões, os procedimentos realizados com detalhes, os constrangimentos ocorridos e as medidas aplicadas deverão ser registrados no prontuário odontológico do trabalhador, que deve ser mantido por um período mínimo de 20 anos após o seu desligamento da empresa. 


\subsubsection{SuPERVISÃo dAS FACILIDAdES DE TREINAMENTO DE PRIMEIROS- SOCORROS E NORMAS DE SEGURANÇA}

Pela NR-7 - Programa de Controle Médico de Saúde Ocupacional todo estabelecimento deverá ter material necessário de primeiros-socorros adequados às atividades desenvolvidas, conservá-los adequadamente e proporcionar treinamento para os trabalhadores.

O cirurgião-dentista do trabalho deve ministrar treinamentos na área que Ihe compete, como, por exemplo, aqueles voltados às primeiras providências a serem tomadas em casos de traumas na região bucomaxilofacial com ou sem lesões dentárias quando o profissional da área não estiver presente.

\subsubsection{Programa de Saúde Bucal da empresa (Odontologia Preventiva, eduCAÇão em Saúde buCal e promoção de saúde) e PreVenção, diagnóstico e tratamento dos Acidentes de TrabalHo e das DoEnças ProfissionaIS}

Como vimos no item 6.8 - relativo à política de saúde da empresa -, o programa de saúde bucal deve tê-la como base. Com base nos níveis de prevenção de Leavell \& Clark (1976), é possível atuar no 1ํnível - promoção de saúde -, no $2^{\circ}$ nível - de proteção específica -, no 3ํㅡível - diagnóstico precoce e tratamento imediato, no $4^{\circ}$ nível - de limitação do dano, e no $5^{\circ}$ nível - reabilitação.

Com os dados levantados pelo Censo Odontológico, poderá ser realizado o planejamento de um Programa de Saúde Bucal na empresa. Devemos lembrar que, geralmente, os recursos são escassos e os 
problemas ilimitados, e que o cirurgião-dentista do trabalho deve administrar o orçamento de forma a otimizá-lo o máximo possível (Pinto, 1996; Moysés, 1997).

Para ter uma margem de manobra ou flexibilidade, o desenho do programa de saúde bucal da empresa deve contemplar mais de uma alternativa de desenvolvimento. O programa ideal é aquele que contempla o alcance de melhorias previstas, e deve trazer vantagens para a saúde dos trabalhadores e para empresa. Como alternativas, podemos sugerir um programa mínimo, cuja atuação esteja concentrada em algumas atividades, e um programa possível, que se inicie com algumas atividades e, paulatinamente, vá se expandindo até se tornar um programa ideal.

A educação em saúde bucal deve estar embasada, conforme Pinto (1996), em quatro passos: conhecer as reais necessidades educativas dos trabalhadores; estabelecer estratégias de ação e executá-las junto com os trabalhadores; avaliar o que foi feito; manter, ao longo do tempo, os ganhos e o entusiasmo quanto à saúde bucal conquistados.

O diagnóstico das reais necessidades educativas deve ser feito em conjunto com os trabalhadores, identificando quais informações são necessárias e importantes para o grupo, ou seja, o que se desconhece e o que deveria ser conhecido por todos ou pela maioria. Nesse processo não se pode deixar de considerar os costumes, os valores, a condição sócioeconômica, as crenças e as práticas de saúde adotadas,.

A seguir são planejadas as estratégias de ação e métodos que serão utilizados no processo de educação, sempre junto com os trabalhadores. A 
avaliação é indispensável para a correção de rota, a verificação da aplicação dos recursos, as práticas de hábitos saudáveis etc., e deve ser realizada durante o processo e não somente ao final. A obtenção de resultados duradouros depende do comprometimento dos atores sociais envolvidos e da constância no processo educativo, a longo prazo, para consolidar essa nova postura de hábitos saudáveis.

A educação em saúde bucal pode ser realizada individualmente ou coletivamente. A vantagem de realizá-la individualmente reside na possibilidade de individualizar os problemas e soluções. Por outro lado, a ação coletiva, embora não contemple os problemas individuais, tem uma abrangência maior, proporcionando economia de tempo e de recursos. A educação em saúde bucal deve contemplar os métodos de educação na clínica, em grupos restritos ou em massa para, a obtenção de melhores resultados.

Quanto à prevenção das doenças bucais, o cirurgião-dentista do trabalho deve juntar as informações do censo odontológico sobre os problemas de saúde bucal mais prevalentes e mais graves da população de trabalhadores, os grupos etários, étnicos, ocupacionais, sócio-econômicos mais atingidos, e conciliá-las com os recursos disponíveis, como capacidade de equipamentos instalados, espaço, clínica, instrumental. Não deve esquecer dos recursos financeiros, dos recursos humanos (ACD, THD, CD), dos materiais de consumo para prevenção, das resistências políticas e administrativas de grupos internos ou externos à empresa e, se possível, deve concretizar parcerias com outras instituições. 
O método preventivo deve reunir as seguintes características: baixo custo em comparação a outros métodos; alta efetividade de proteção, evitando a doença bucal; e longo tempo de permanência, evitando reaplicações freqüentes (Pinto, 1996).

Não é escopo desta dissertação definir e aprofundar-se quanto aos métodos a serem utilizados para a prevenção de cada doença bucal, pois existem excelentes publicações na literatura que poderão ser consultadas. Assim, apenas citaremos tais métodos.

Há vários testes laboratoriais para a avaliação do risco de cáries. Para a prevenção da cárie dental e da doença periodontal são usualmente adotados: aplicações tópicas de flúor com gel, verniz, soluções fluoretadas; aplicação de selantes de fóssulas e fissuras; tratamento não-operativo de lesões incipientes; análise e orientação dietética; bochechos fluoretados supervisionados; higiene bucal supervisionada (escovação e fio dental); bochechos fluoretados caseiros; dentifrícios fluoretados; higiene bucal caseira (escovação e fio dental) e bochechos com agentes químicos antiplaca bacteriana (Chaves, 1986; Pinto, 1992; Pinto, 1993; Pinto, 1996; Kriger, 1997; Buischi, 2000; Pinto, 2000).

Também existe a responsabilidade de estabelecer um diagnóstico precoce de desvios da normalidade bucal que indiquem maloclusão, câncer, AIDS, manifestações bucais de doenças profissionais ou outros problemas bucais. É necessário orientar os trabalhadores para que realizem o autoexame bucal, ao menos duas vezes por ano, para observar mudanças na coloração da pele e mucosas, áreas irritadas ou com dormência, feridas que 
não se cicatrizam, dentes fraturados ou com mobilidade, inchaço, caroços etc. (Pinto, 1996).

No caso de acidentes do trabalho e de doenças profissionais, a ênfase deve se concentrar na promoção de saúde, na proteção específica e no máximo no diagnóstico precoce e tratamento imediato, a partir do 4ํㅡível ou de limitação do dano, e 5ำ nível ou de reabilitação. Nessas situações, há que se refletir sobre as medidas anteriores, que devem ser revistas e aprimoradas.

O Anexo 9 traz uma relação de agentes biológicos, químicos, físicos e mecânicos que podem causar doenças profissionais - e suas respectivas manifestações bucais. Essa lista foi adaptada de Schour \& Sarnat (1942) por Midorikawa \& Nagano (1995) e Midorikawa et al. (1996), e poderá ajudar quando da suspeita de determinada intoxicação e auxiliar no diagnóstico precoce de algumas patologias, situação em que o CD deverá encaminhar o paciente ao ao médico do trabalho para confirmação do diagnóstico (Nogueira, 1972).

Confirmado o diagnostico de doença profissional, ou em caso de acidente do trabalho, deve o cirurgião-dentista do trabalho as lesões que atingem o complexo bucomaxilofacial ou referenciar o trabalhador aos serviços especializados.

\subsubsection{Odontologia Restauradora ou Curativa ou Assistencial}

Desde o começo do século, as empresas americanas que empregavam o cirurgião-dentista normalmente referenciavam os 
trabalhadores para tratamento com cirurgião-dentista particular. Realizavam apenas procedimentos de urgência (alívio da dor) e atendiam casos de acidentes do trabalho até seu encaminhamento para tratamento definitivo.

Thomas (1918); Legge (1937); Miller (1941); Dunning et al. (1941) e Walls (1942) relatam que, em empresas como a Sears, Roebuck \& Co., que implantaram serviços odontológicos, houve aumento no padrão de eficiência. Isto se deu em decorrência da realização de exames odontológicos, da eliminação de focos de infecção por meio de exames, higiene, prevenção e educação odontológica e de procedimentos como extrações e algumas restaurações. As intercorrências mais graves eram encaminhadas para tratamento com o CD da família ou outro profissional de escolha do trabalhador.

Dependendo da política de saúde adotada, a empresa pode facilitar de seus funcionários à assistência odontológica aos seus funcionários das maneiras que seguem: autogestão em empresas públicas, com serviços próprios ou compra de serviços (por exemplo o CIEFAS); autogestão no setor privado (por exemplo, a ABRASPE); condomínio ou associação de empresas (por exemplo o SESI, SESC, SECONCI); cooperativas odontológicas (por exemplo, a UNIODONTO); odontologia de grupo (por exemplo, o SINOG); seguro saúde (por exemplo, a Federação Nacional das Empresas de Seguros Privados e de Capitalização - FUNASEG).

Assim, temos uma infinidade de coberturas de procedimentos odontológicos e formas de custeio que podem ser adotados. A função do cirurgião-dentista do trabalho é gerenciar esse sistema, dando suporte 
técnico à empresa quanto às condições de saúde bucal dos trabalhadores e mantendo contato com os cirurgiões-dentistas operacionais para atualizar os dados das condições bucais dos trabalhadores. Esse profissional também deve avaliar as condições de saúde bucal dos trabalhadores nos exames periódicos e, caso haja necessidade de tratamento odontológico, referenciálos para a área de assistência odontológica.

\subsubsection{Participação na Comissão Interna de Prevenção de Acidentes (CIPA)}

A Portaria no 08, de 23 de fevereiro de 1999, altera a Norma Regulamentadora NR 5, aprovada pela Portaria oㅡ 3214, de 08 de junho de 1978, que dispõe sobre a Comissão Interna de Prevenção de Acidentes CIPA - e dá outras providências. Apresenta o objetivo da CIPA como " $a$ prevenção de acidentes e doenças decorrentes do trabalho, de modo a tornar compativel permanentemente o trabalho com a preservação da vida e a promoção da saúde do trabalhador".

A CIPA é composta por representantes dos funcionários, que são eleitos, e funcionários indicados pela diretoria da empresa. É dimensionada de acordo com o número total de empregados e tem as seguintes funções:

a) identificar os riscos do processo de trabalho, e elaborar o mapa de riscos, com a participação do maior número de trabalhadores, com assessoria do SESMT, onde houver;

b) elaborar plano de trabalho que possibilite a ação preventiva na solução de problemas de segurança e saúde no trabalho;

c) participar da implementação e do controle da qualidade das medidas de prevenção necessárias, bem como da avaliação das prioridades de ação nos locais de trabalho; 
d) realizar, periodicamente, verificações nos ambientes $e$ condições de trabalho visando a identificação de situações que venham trazer riscos para a segurança e saúde dos trabalhadores;

e) realizar, a cada reunião, avaliação do cumprimento das metas fixadas em seu plano de trabalho e discutir as situações de risco que foram identificadas;

f) divulgar aos trabalhadores informações relativas à segurança e saúde no trabalho;

g) participar, com o SESMT, quando houver, das discussões promovidas pelo empregador, para avaliar os impactos de alterações no ambiente e processo de trabalho relacionados à segurança e saúde dos trabalhadores;

h) requerer ao SESMT, quando houver, ou ao empregador, a paralisação de máquina ou setor onde considere haver risco grave e iminente à segurança e saúde dos trabalhadores;

i) colaborar no desenvolvimento e implementação do PCMSO e PPRA e de outros programas relacionados à segurança e saúde no trabalho;

j) divulgar e promover o cumprimento das Normas Regulamentadoras, bem como cláusulas de acordos $e$ convenções coletivas de trabalho, relativas à segurança $e$ saúde no trabalho;

k) participar, em conjunto com o SESMT, onde houver, ou com o empregador da análise das causas das doenças e acidentes de trabalho e propor medidas de solução dos problemas identificados;

l) requisitar ao empregador e analisar as informações sobre questões que tenham interferido na segurança e saúde dos trabalhadores;

m) requisitar à empresa as cópias das CAT emitidas;

n) promover, anualmente, em conjunto com o SESMT, onde houver, a Semana Interna de Prevenção de Acidentes do Trabalho - SIPAT;

o) participar, anualmente, em conjunto com a empresa, de Campanhas de Prevenção da AIDS.

Diante do exposto, concordamos com Silva \& Souto (1983b), Caetano \& Watanabe (1994) e Midorikawa \& Nagano (1995), que postulam que o cirurgião-dentista deve participar da CIPA para orientá-la em todos os assuntos relacionados à saúde bucal, tanto em doenças profissionais quanto 
em acidentes do trabalho que se manifestem ou atinjam a cavidade bucal, visando o melhor cumprimento do objetivos dessa Comissão.

\subsubsection{ACONSELHAMENTO, À GERÊNCIA DA EMPRESA EM TODO ASSUNTO RELACIONADO COM A SAÚDE DO TRABALHADOR}

Deve o cirurgião-dentista do trabalho estar preparado para, junto com a equipe de saúde do trabalhador, aconselhar, esclarecer e orientar a administração sobre os assuntos relativos à saúde do trabalhador.

Com o passar do tempo surgirão novas legislações, normas e problemas que exigirão a adoção de novas diretrizes na política de saúde. Estas devem ser refletidas e discutidas com a gerência e a equipe de saúde do trabalhador da empresa.

\subsubsection{Avaliação E/OU AUditORIA NO CAMPO DA OdONTOLOGIA}

Conforme a lei $\mathrm{n}^{0}$ 5081, de 24 de agosto de 1966, que regula o exercício da odontologia, em seu artigo 6º, item IV, compete ao cirurgiãodentista proceder à realização de perícia odontolegal em foro cível, criminal, trabalhista e em sede administrativa.

Segundo Silva $(1994,1997)$, quando se tratar de convênios é melhor utilizar o termo avaliação ou auditoria, para evitar confusão com a "perícia em âmbito jurídico, cuja realização somente pode ser determinada por autoridade policial ou judicial".

A "perícia de convênio" seria 
"procedimento administrativo e técnico que emprega critérios objetivos para verificação dos serviços e procedimentos odontológicos, pré ou pós tratamento, em beneficiários, analisando elou verificando, se os profissionais credenciados (conveniados, cadastrados, etc.) enquadram-se nas normas e objetivos prédeterminados pela mantenedora, confirmando ou não os honorários praticados" (Peres, 1997).

Os CDs que prestam assistência devem declarar expressamente que estão cientes da realização da avaliação, comprometendo-se a acatar o resultado dos padrões previamente estabelecidos.

Como em qualquer tipo de benefício concedido pela empresa, é cada vez mais imprescindível e necessário manter um excelente padrão de qualidade dos serviços odontológicos prestados pela área de assistência odontológica. Isto deve ocorrer mesmo quando a empresa reembolsa parcial ou totalmente o empregado pelas despesas com o tratamento odontológico, pois o tipo de assistência odontológica oferecida aos trabalhadores depende da política de saúde da empresa.

Quando a empresa fornece assistência odontológica, ou credencia CDs para atender os funcionários, o cirurgião-dentista do trabalho pode realizar a avaliação ou a auditoria desses serviços para aferir a qualidade dos tratamentos, atualizar os dados clínicos do trabalhador e dar suporte técnico à administração da empresa nas decisões relativas à assistência odontológica, reclamação de algum tratamento etc.

Segundo Livraghi (1983), quanto à procedência dos profissionais a auditoria odontológica pode ser:

$>$ INTERNA: quando é realizada por CD da Empresa

$>$ EXTERNA: quando é realizada por CD externo à Empresa 
> MISTA: quando é realizada tanto por CD interno quanto por CD externo à Empresa

Essa avaliação deve ser feita, preferencialmente, antes do tratamento (inicial), para verificar se o plano de tratamento está adequado ao tipo de cobertura do plano, e após a sua realização (final), para verificar se o tratamento proposto foi efetivamente realizado. Pode ser DIRETA realizada no própio paciente - ou INDIRETA - realizada pela observação de fichas, modelos de gesso, radiografias e outros documentos. Seu alcance pode ser TOTAL - ou seja, em todos os pacientes - ou PARCIAL - realizada apenas em uma amostra do público total.

Os problemas técnicos devem ser resolvidos entre os profissionais, sem a presença de terceiros e de pacientes. Quando houver necessidade de abrir uma sindicância administrativa, deve ser concedido amplo espaço ao CD operacional para defesa.

Finalizando, não se pode deixar de enfatizar a necessidade de preparo e de conhecimento, por parte do cirurgião-dentista do trabalho, das diversas áreas da odontologia, de odontologia legal e do código de ética odontológico.

\subsubsection{Perícia, No Campo da Odontologia em SaÚde do trabalHador, NA QUALIDADE DE PERITO DO JUIZZO OU ASSISTENTE TÉCNICO}

A infortunística é definida como a "parte da Medicina Legal, Medicina Social e do Trabalho que trata dos acidentes do trabalho, doenças profissionais e do trabalho" (França, 1995). 
Dessa forma, é também um ramo da Odontologia Legal, Odontologia Social e da Odontologia em Saúde do Trabalhador que trata dos acidentes do trabalho e das doenças profissionais e do trabalho que incidem sobre o complexo bucomaxilofacial, influenciando ou não a capacidade laborativa do empregado.

A medicina, a engenharia, a psicologia, a odontologia e outras áreas do conhecimento vêm se preocupando, ao longo dos anos, com o que a atual legislação denomina de Acidentes do Trabalho (Acidentes do Trabalho, Doenças Profissionais e Doenças do Trabalho).

No campo da Odontologia, temos vários autores que se debruçaram sobre o assunto, como por exemplo Álvaro Dória (1941) - que apresentou como Tese de Cátedra o tema "Infortunística e Odontologia" no qual analisa, além dos chamados "acidentes do trabalho", o aspecto pericial dos mesmos -, e Schour \& Sarnat (1942) - que publicaram um trabalho no qual descrevem as manifestações bucais das doenças profissionais.

\subsection{Legislação}

A realidade dos acidentes do trabalho acarretou na necessidade de proteção do empregado, com vistas à possibilidade de recebimento de indenização em caso de infortúnio.

Em nosso, país a legislação sobre acidentes do trabalho (Carvalho et al., 1965; Mendes, 1980; Mendes, 1995; Buono Neto \& Buono, 1996) iniciou-se com a Lei $n^{\circ} 3724$, de 1919; a segunda lei sobre a matéria foi o Decreto $n^{\circ}$ 24.637, de 1934, mas a conceituação de Acidente do Trabalho 
somente foi estabelecida com o Decreto-Lei n 7036, de 1944. Em 1967, a Lei $n^{\circ} 5316$ equiparou o Acidente do Trabalho e a Doença do Trabalho e, também, atribuiu à Previdência Social o seguro de Acidente do Trabalho.

A legislação atualmente em vigor está representada pelas leis no 8212 e ํo 8213 , ambas de 1991. A primeira diz respeito ao plano de custeio, e a segunda aos planos de Benefícios da Previdência Social (Brasil, 1991a; Brasil, 1991 b; Paixão, 1994; Mendes, 1995).

No artigo 18 da lei 8213/91, encontram-se elencados os benefícios a que têm direito os segurados ou seus dependentes no que diz respeito à aposentadoria por invalidez, ao auxílio-acidente, ao auxílio-doença, à pensão por morte, ao pecúlio por invalidez ou morte, ao serviço social e à reabilitação profissional.

O artigo 19 da lei anteriormente citada define Acidente do Trabalho como "o que ocorre pelo exercício do trabalho a serviço da empresa ou pelo exercício do trabalho dos segurados referidos no inciso VII do artigo 11 desta lei, provocando lesão corporal ou perturbação funcional que cause a morte ou a perda ou redução, permanente ou temporária, da capacidade para o trabalho".

Já no art. 20, inciso I, encontramos a definição de Doença Profissional como aquela "produzida ou desencadeada pelo exercício do trabalho peculiar a determinada atividade e constante da respectiva relação elaborada pelo Ministério do Trabalho e da Previdência Social". O inciso II, por sua vez, define Doença do Trabalho como aquela "adquirida ou desencadeada em função de condições especiais em que o trabalho é realizado e com ele se relacione diretamente, constante da relação mencionada no inciso I". 
E, finalmente, o último artigo que merece referência em razão do que está sendo discutido é o art. 21, que trata de casos em que existe a equiparação com o Acidente do Trabalho - inciso I "o acidente ligado ao trabalho que, embora não tenha a causa única, haja contribuído diretamente para a morte do segurado, para a redução ou perda da sua capacidade para o trabalho, ou produzido lesão que exija atenção médica para a recuperação". O inciso II postula que o acidente sofrido pelo segurado no local e no horário de trabalho, em conseqüência de agressão, sabotagem, ofensa física intencional, ato de imprudência, negligência ou imperícia etc. deve ser enquadrado como acidente do trabalho. No Inciso III é citada a doença proveniente de contaminação acidental no exercício da função. E o inciso IV contempla acidente fora do local e horário de trabalho, como por exemplo, no percurso da residência para o local de trabalho qualquer que seja o meio de locomoção (Brasil, 1991b).

\subsection{Doutrina do Infortúnio do Trabalho}

Inicialmente, a doutrina judiciária, presumia sempre a existência de culpa (Fávero, 1954), ou seja, a ocorrência de acidente implicava existência de imprudência, negligência ou imperícia de alguém. Porém, estudos realizados em diferentes demonstraram que essa premissa nem sempre é verdadeira. Na realidade, ficou comprovado que, na etiologia dos infortúnios a contribuição maior era do que se denominou de RISCO PROFISSIONAL (Dória, 1941; Fávero, 1954; Arbenz, 1959; Carvalho et al., 1965; Arbenz, 1988; França, 1995), que seria a possibilidade de perigo própria e inerente a 
todo trabalho. Portanto, nessas situações, quando ocorrer dano à saúde do trabalhador, a culpa não deve ser imputada a alguém.

A etiologia dos acidentes, segundo Carvalho et al. (1965), distribuise conforme o quadro abaixo:

Quadro 1 - Principais causas de acidentes do trabalho e suas porcentagens.

\begin{tabular}{|l|c|}
\hline \multicolumn{1}{|c|}{ CAUSAS DE ACIDENTES DO TRABALHO } & PORCENTAGENS (\%) \\
\hline Falta do empregador & 08 \\
Falta do empregado & 16 \\
Falta de ambos & 03 \\
Falta de terceiros & 03 \\
Risco Profissional & 69 \\
Outras causas & 01 \\
\hline
\end{tabular}

Fonte: Carvalho et al., 1965

Como pode ser verificado, o Risco Profissional é o responsável por 69\% dos Acidentes do Trabalho. Ressalte-se que, na hipótese de ter havido a notificação da existência de situações que aumentem esse risco, e de não terem sido tomadas as providências devidas, caberá ao responsável pela empresa a responsabilidade - penal e civil - no caso de ocorrência de acidentes (Campos, 1991).

Essa nova postura perante o infortúnio do trabalho trouxe benefícios para o trabalhador porque anteriormente, como conseqüência da presunção da culpa, os processos eram muitos demorados. Com a introdução da Doutrina do Risco Profissional, houve uma agilização dos trâmites processuais, apesar do aumento do volume de processos. 


\subsection{Aspectos Médico-Legais}

Para que se configure o acidente de trabalho é necessário que, como conseqüência do dano, decorra perturbação física ou psíquica. A perturbação física pode ser classificada em lesão corporal, perturbação funcional (incapacidade) ou doença que resulte em morte, perda total ou parcial, permanente ou temporária da capacidade para o trabalho (França, 1995).

Na perturbação psíquica, estão enquadradas aquelas situações em que, apesar da não existência do dano físico, geraram perturbações que impedem um bom desempenho do trabalhador - que estará mais vulnerável aos riscos de acidentes do trabalho, bem como de eventuais doenças profissionais.

Em ambos os casos, é necessário que a causa tenha agido direta ou indiretamente para resultar no dano. As causas podem ser classificadas em: causa eficiente, que é sempre necessária mas nem sempre é suficiente para provocar o dano; causa coadjuvante, que é aquela que permite a ação da causa eficiente; causa predisponente, representada por fatores antecedentes em relação à ocorrência do dano.

O empregador não poderá argumentar que o empregado já se encontrava predisposto ao acidente porque entende a Doutrina que, tendo sido aceito para o trabalho, o indivíduo apresentava condições de saúde para tanto.

A legislação não diferencia se o trabalho contém ou apenas possui condições para a ocorrência do dano. Porém, é necessário que se verifique 
o nexo causal, ou seja, que se admita a correlação entre o trabalho e o infortúnio - acidente-tipo, doença profissional e doença do trabalho (Carvalho et al., 1965; Arbenz, 1988).

O infortúnio do trabalho é dividido em:

Acidente-Tipo - que se caracteriza por um trauma súbito, violento, concentrado, com patogenia manifesta e relativamente independente do tipo do trabalho. A profilaxia desses eventos é feita em âmbito geral como, por exemplo, características especiais do equipamento de trabalho que visem maior segurança do operador (Arbenz, 1988). O Acidente-Tipo, como acontece de maneira súbita, pode ser causado por peças de máquinas, instrumentos, engrenagens, fragmentos de peças, pós abrasivos etc. que, atingindo o complexo maxilofacial podem lesar lábios, bochechas, queixo, dentes, maxilares, glândulas salivares, língua, abóbada palatina, assoalho da boca, atingindo mucosa, vasos sangüíneos, vasos linfáticos, músculos e/ou nervos (Dória, 1941).

Doença Profissional - também denominada de Idiopatia ou Ergopatia - que tem um caráter lento, crônico, diluído no tempo, com patogenia insidiosa, dependente do tipo de trabalho. A profilaxia desse infortúnio é específica, por exemplo, a prevenção contra a intoxicação por chumbo, mercúrio etc. Nas Doenças Profissionais que ocorrem de maneira lenta, crônica, temos uma série de agentes físicos, químicos, biológicos e mecânicos que levam a manifestações na cavidade oral que estão relacionadas a determinados tipos de trabalhos, como podemos observar no quadro constante do Anexo 9 (Brinõn, 1984; Midorikawa \& Nagano, 1995; Midorikawa et al., 1996). Percebemos que há carência de estudos mais aprofundados e recentes sobre esse tema, que se reflete na existência de dúvidas acerca dos processos etiofisiopatogênicos. Assim, em virtude dessa escassez, o presente trabalho procurou reunir dados de diversas áreas correlatas. 
Doença do Trabalho - também chamada de Mesopatia, cuja causa está diluída no tempo, e que tem um caráter inespecífico, como as varizes, as LERs etc.

Nos casos de infortúnio do trabalho a indenização é concedida após a verificação do nexo causal e da avaliação da origem do dano - se por ação direta ou indireta do trabalho, caso fortuito ou força maior, ou mesmo culpa da vítima. Só não há indenização quando houver dolo da vítima.

\subsection{Perícia}

Novamente citamos a lei oㅜ 5081, 24 de agosto de 1966, que estabelece:

"Art. $6^{\circ}$ Compete ao cirurgião-dentista:

IV - proceder a perícia odonto-legal em foro cível, criminal, trabalhista e em sede administrativa...

IX - utilizar no exercício da função de Perito Odontológico, em caso de necropsia, as vias de acesso do pescoço e da cabeça."

Silva (1994) cita a definição de Souza Lima sobre diligência médicolegal: "diligência Médico Legal é toda sindicância promovida por autoridade policial ou judiciária acompanhada de exame, em que, pela natureza do mesmo, os peritos são ou devem ser médicos".

Para Silva (1997), essa definição é "perfeitamente aplicável à atividade pericial odontológica par ao qual os peritos são ou devem ser cirurgiões-dentistas".

Brandimiller (1996) conceitua perícia como sendo "o exame de situações ou fatos relacionados a coisas e pessoas, praticado por especialista na matéria que lhe é submetida, com o objetivo de elucidar determinados aspectos técnicos (em geral especificados através de quesitos)”. 
A perícia tem como objetivo prestar esclarecimentos técnicos para a Justiça, através da redação de um laudo decorrente de um exame pericial (Silva, 1994). Buono Neto \& Buono (1996) citam cinco objetivos das perícias, que são:

1) esclarecimento de dúvidas, estabelecendo a verdade, demonstrando tecnicamente a existência ou não da causa alegada;

2) conclusão fundamentada em dados coerentes e precisos, sem deixar dúvidas;

3) utilização, no laudo, de termos que permitam sua compreensão por leigos;

4) a prova técnica irrefutável, para fundamentar a sentença pelos Juizes; e,

5) qualidade técnica invulnerável a impugnações, tanto no campo técnico como no jurídico.

A perícia trabalhista - ou de infortúnios do trabalho - pode ser realizada pelo cirurgião-dentista em acidentes-tipo, quando a face e a cavidade bucal são atingidas, ou em doenças profissionais com manifestações bucais.

A perícia em infortunística obedece o mesmo padrão das perícias de outras áreas. Assim, o perito deve sempre realizar uma análise cuidadosa da documentação ou do processo; realizar, no exame pericial, a anamnese ocupacional, a anamnese clínica e o exame clínico minucioso e, se necessário, pedir a realização de exames complementares e pareceres.

Pode ser necessária a vistoria do local de trabalho e de suas condições, da organização do trabalho, além da avaliação dos dados epidemiológicos e da identificação dos riscos físicos, químicos, biológicos, 
mecânicos e ergonômicos etc. Assim, e de posse de todas as informações necessárias, o perito poderá elaborar o laudo, respondendo aos quesitos formulados pela Justiça e pelas partes envolvidas.

As perícias objetivam a comprovação ou não da existência do dano, a verificação do nexo causal e a qualificação e quantificação do dano no artigo da Lei dos Acidentes do Trabalho (Dória, 1941; Arbenz, 1988; Paixão, 1994; França, 1995).

Os compêndios de Medicina e Odontologia Legal atentam para os cuidados que o perito deve tomar, durante a realização do exame clínico, quanto à possibilidade de simulação pelo paciente, de lesões inexistentes ou de lesões existentes, mas independentes do trabalho ou ainda, de lesões existentes e parcialmente dependentes do trabalho.

O cirurgião-dentista do trabalho pode ser chamado para exercer a função de perito do juízo ou de assistente técnico de uma das partes. $O$ papel do assistente técnico é analisar o processo e assessorar tecnicamente o advogado da parte que o contratou para, juntos, redigirem os quesitos que serão respondidos pelo perito do juízo de forma a justificar a tese do advogado. Deve também acompanhar a perícia tanto no exame clínico quanto no local de trabalho. $O$ assistente técnico poder concordar ou não com o laudo do perito oficial. Caso não concorde, pode apresentar outro laudo, com base cientifica e consciente, pois está a par dos dados colhidos pelo perito.

No Decreto oㅜ 3.048, de 6 de maio de 1999 (Anexo 10), que aprova o Regulamento da Previdência Social encontramos as lista de agentes e 
fatores de risco de natureza ocupacional relacionados à etiologia de doenças profissionais e de outras doenças relacionadas ao trabalho, e também algumas manifestações bucais de doenças profissionais (Brasil, 1999a).

A Portaria do Ministério da Saúde nำ 1339, de 18 de novembro de 1999 (Anexo 11), instituiu a Lista de Doenças relacionadas ao trabalho, a ser adotada como referência nos agravos originados no processo de trabalho no Sistema Único de Saúde, para uso clinico e epidemiológico. Junto com o Decreto acima, lista algumas manifestações bucais de doenças profissionais como erosão dentária, alterações pós-eruptivas da cor dos tecidos duros dos dentes, gengivite crônica e estomatite ulcerativa crônica (Brasil, 1999b).

A Resolução do Instituto Nacional do Seguro Social INSS/DC/ n010, de 23 de dezembro de 1999 (Anexo 12), aprovou os protocolos médicos periciais de doenças relacionadas ao trabalho. Nessa Portaria são descritas a erosão dentária, as alterações pós-eruptivas da cor dos tecidos duros dos dentes (dentes manchados), a gengivite crônica e a estomatite ulcerosa crônica e como diagnosticá-las, avaliá-las e os procedimentos para o reconhecimento técnico do nexo causal entre a doença e o trabalho. Apesar de constarem como procedimentos médico-periciais, deve o cirurgiãodentista realizar tais perícias (Brasil, 2000a).

No Anexo III do Decreto no 3.048, de 6 de maio de 1999 (Anexo 10), temos a relação das situações que dão direito ao auxilio acidente. No quadro no 4 do referido Decreto temos que acidentes que atinjam crânio e/ou face e/ou pescoço, ou que provoquem perda de dentes - desde que ocorra também deformação da arcada dentária que impeça o uso de prótese -, são 
considerados como prejuízo estético em grau médio ou máximo. O quadro № 6 do Decreto no 3.048 trata das alterações articulares, e a primeira situação apresentada é a redução dos movimentos de mandíbula de grau médio ou superior - para o enquadramento nesses graus, o documento estabelece os critérios: grau mínimo - redução de até um terço da amplitude normal do movimento da articulação; grau médio - redução de mais de um terço e até dois terços da amplitude normal do movimento da articulação; grau máximo - redução acima de dois terços da amplitude normal do movimento da articulação.

No quadro o 4 do Decreto no 3.048 observa-se a falta de critérios para avaliação do prejuízo estético, pois, se a deformação da arcada dentária impede o trabalhador de usar prótese, decorre de um acidente de grandes proporções. O que deve acontecer mais freqüentemente em acidentes do trabalho de menor proporção são perdas ou fraturas dentais que prejudicam a estética, a função mastigatória e até a função de fonação, e, mesmo com o uso de prótese, as funções e a estética originais jamais serão retomadas.

Acompanhamos um caso de acidente do trabalho em que a queda de parte do reboco de uma parede sobre o trabalhador provocou cortes no lábio superior e na mucosa bucal vestibular, além da fratura da coroa do dente incisivo central superior. Resta-nos a dúvida: como se enquadra essa lesão?

Aspecto importante a ser considerado é a recomendação de que, na avaliação do aspecto desagradável, sejam levados em conta o sexo, a idade 
e a profissão do acidentado. Apesar de algumas profissões exigirem melhor aparência que outras, e de que a idade e o sexo tenham influência na avaliação, qualquer perda de elementos dentários por trauma ou doença profissional causa deformidade estética, problemas funcionais e trauma psicológico no trabalhador que jamais serão resolvidos pelo uso de prótese, qualquer que seja esta.

\subsection{ANÁLISE DOS QUESTIONÁRIOS}

Com relação ao questionário aplicado nas empresas, percebemos que a composição dos SESMTs respeita a legislação em vigor, poucas incluíram outros profissionais além daqueles estabelecidos pela Lei.

Também constatamos que as empresa estão conscientes da influência e importância da odontologia do trabalho, mas ainda incluíram profissionais da área nas equipes do SESMT.

A visão da atuação e colaboração da odontologia na saúde do trabalhador ainda é conservadora, tanto por parte da empresa e do SESMT quanto pelos próprios CDs. Não está errado atribuir, ao CD do trabalho, as funções de proferir palestras e realizar ações corretivas e preventivas, mas limitar a atuação desse profissional a elas caracteriza uma visão estreita sobre as possibilidades de atuação da odontologia na equipe de saúde do trabalhador. 
A maioria das empresas ainda possui uma visão conservadora da atuação do cirurgião-dentista e, não raras vezes, não entendem o que vem a ser a odontologia em saúde do trabalhador, o que nos leva a recomendar que a classe odontológica envide esforços no sentido de esclarecer empresários, trabalhadores e sociedade sobre a importância social dessa atuação. 


\section{CONCLUSÕES}

A revisão da literatura possibilitou-nos uma visão mais detalhada da evolução, atuação e conceito da Odontologia em Saúde do Trabalhador, permitindo o balizamento dessa nova área de atuação do cirurgião-dentista. Assim, e considerando as condições de realização do presente estudo, permitimo-nos concluir que:

1. A Odontologia não pode ficar alheia à área de Saúde do Trabalhador, em que diferentes profissões se unem buscando melhores condições de saúde àqueles que movem a sociedade com sua força de trabalho. Como vimos, a contribuição dos profissionais dessa área do conhecimento é muito significativa, pois os cirurgiões-dentistas são capazes de estabelecer o diagnóstico precoce de doenças profissionais que apresentam manifestações bucais.

2. A manutenção de um bom estado de saúde bucal é importante para que o trabalhador possa desempenhar sua atividades laborativas e sociais de forma segura e produtiva.

3. Todos os atores sociais dessa interface têm ganhos: o trabalhador, a empresa, os SESMTs, o cirurgião-dentista do trabalho, a odontologia e o país. 
4. Na atuação pericial, o cirurgião-dentista poderá realizar desde avaliações técnicas de tratamentos odontológicos a perícias ligadas às áreas trabalhista e cível, desde que desenvolva competência, capacidade e habilidade em Deontologia e Odontologia Legal.

5. É imprescindível que novas pesquisas sobre a inserção do cirurgiãodentista nessa área do conhecimento sejam realizadas, pois muitas questões ainda carecem de elucidação e/ou aprofundamento.

6. A análise dos questionários leva-nos a concluir que é necessário um trabalho de esclarecimento e conscientização - voltado às empresas, aos trabalhadores, ao governo, aos sindicatos, aos profissionais da área de saúde do trabalhador e à classe profissional odontológica -, sobre a importância do cirurgião-dentista do trabalho.

7. No momento, a Odontologia em Saúde do Trabalhador é competência do cirurgião-dentista, mas, a médio prazo, tornar-se-á uma especialidade da Odontologia. 


\section{ANEXO 1 \\ ORGANIZAÇÃO INTERNACIONAL DO TRABALHO \\ RECOMENDAÇÃO N. ${ }^{\circ} 112$}

\section{Recomendação sobre os Serviços de Medicina. do Trabalho nos locais de trabalho}

A Conferência Geral da Organização Internacional do Trabalho:

Convocada em Genebra pelo Conselho de Administração do Escritório Internacional do Trabalho e congregada na referida cidade, em 3 de junho de 1959, em sua $43^{\mathrm{a}}$ reunião;

Depois de ter decidido adotar diversas proposições relativas à organização dos serviços de medicina do trabalho nos locais de emprego, questão que constitui o quarto ponto da ordem do dia da reunião, e

Depois de ter decidido que as referidas proposições se revestem na forma de recomendação, adota, com data de vinte e quatro de junho de mil novecentos e cinqüenta e nove, a seguinte Recomendação, que poderá ser citada como a Recomendação sobre os serviços de medicina do trabalho, 1959:

\section{I - DEFINIÇÃO}

1 - Para os efeitos desta Recomendação, a expressão "serviços de medicina do trabalho" designa um serviço organizado nos locais de trabalho ou em suas imediações, destinado:

a) garantir a proteção dos trabalhadores contra todo o risco que prejudique a sua saúde e que possa resultai de seu trabalho ou das condições em que este se efetue;

b) a contribuir na adaptação física e mental dos trabalhadores em particular pela adequação do trabalho aos trabalhadores e por sua colocação em postos de trabalho correspondentes a suas aptidões;

c) a contribuir ao estabelecimento e manutenção do nível mais elevado possível de bem estar físico e mental dos trabalhadores.

\section{II - MÉTODO DE APLICAÇÃO}

2 - Levando-se em consideração a diversificação de condições e de prática nacionais, os serviços de medicina do trabalho poderiam, segundo as circunstâncias, criar-se:

a) por via legislativa;

b) em virtude de contratos coletivos ou de quaisquer outros acordos concertados entre os empregadores e os trabalhadores interessados;

c) de qualquer outra forma reconhecida pela autoridade competente, com prévia consulta às organizações de empregadores e de trabalhadores. 


\section{III - ORGANIZAÇÃO}

3 - Segundo as circunstâncias e as normas aplicáveis, os serviços de medicina do trabalho deveriam:

a) serem organizados por empresas interessadas ou agregadas a um organismo exterior;

b) serem organizadas:

i) como serviços próprios de uma empresa; ou

ii) como serviços comuns a certo número de empresas.

4 - Para que todos os trabalhadores possam aproveitar os benefícios da medicina do trabalho, deveriam ser organizados serviços de medicina do trabalho nas empresas industriais, não industriais e agrícolas, assim como nos serviços públicos. Entretanto, quando os serviços de medicina do trabalho não possam ser estabelecidos imediatamente em todas as empresas, estes serviços deveriam ser organizados em primeiro lugar:

a) nas empresas onde os riscos são geralmente mais importantes;

b) nas empresas onde a saúde dos trabalhadores está exposta a riscos especiais; e

c) nas empresas que empregam um número de trabalhadores superior a um mínimo fixado.

5 - Quando a organização de um serviço de medicina do trabalho, tal como se define nesta Recomendação, não seja possível de imediato, por razões geográficas ou por outras razões que haverá de precisar a legislação nacional, a empresa deverá consertar um acordo com um médico ou com um serviço médico local que estaria encarregado de:

a) prestar os atendimentos de urgência;

b) realizar os exames médicos prescritos pela legislação nacional;

c) garantir a vigilância das condições de higiene da empresa.

\section{IV - FUNÇÕES}

6 - A função dos serviços de medicina do trabalho deveria ser essencialmente preventiva.

7 - Os serviços de medicina do trabalho não deveriam se encarregar de comprovar se as ausências por doenças são ou não justificadas. Isto não deveria impedir que os serviços de medicina do trabalho se certifiquem das circunstâncias que podem motivar uma ausência por doença e da evolução das doenças dos trabalhadores para melhor avaliar a eficácia de seu programa de prevenção, descobrir os riscos profissionais e destinar os trabalhadores a trabalhos apropriados, com vistas a sua readaptação.

8 - Na medida que uma ou várias das funções seguintes não estiverem garantidas de maneira satisfatória, de conformidade com a legislação ou a prática nacionais, por 
outros serviços apropriados, as funções dos serviços de medicina do trabalho deveriam desenvolver-se progressivamente, segundo as circunstâncias, de maneira que compreendam em particular:

a) a vigilância, na empresa, de todos os fatores que possam afetar a saúde dos trabalhadores, e o assessoramento para a direção e aos trabalhadores ou a seus representantes na empresa, nesta matéria;

b) o estudo dos postos de trabalho ou a participação neste estudo desde os pontos de vista higiênicos, fisiológicos e psicológicos, e o assessoramento para a direção e aos trabalhadores nas questões que se referem para a melhor disposição possível dos postos de trabalho desde estes pontos de vista;

c) a participação com os organismos ou serviços interessados da empresa, na prevenção dos acidentes do trabalho e das doenças profissionais e na vigilância dos meios de proteção pessoal e de sua utilização, assim como o assessoramento para a direção e aos trabalhadores nesta matéria;

d) a vigilância da higiene das instalações sanitárias, assim como de todas as instalações da empresa previstas para o bem estar do trabalhador, tais como cozinhas, cantinas, creches, residências de repouso e, em caso necessário, a vigilância dos regimes alimentares para os trabalhadores;

e) os exames médicos de admissão ao emprego e os exames periódicos e especiais, incluindo, em caso necessário, os exames laboratoriais e radiológicos, prescritos pela legislação nacional ou por acordo entre as partes ou organizações interessadas ou que o médico do trabalho estime convenientes desde o ponto de vista preventivo; os referidos exames deveriam ser previstos para garantir uma vigilância particular de determinadas categorias de trabalhadores, expostos a riscos especiais, e ás pessoas de capacidade física diminuídas;

f) a vigilância da adequação do trabalho para os trabalhadores, e em particular aos trabalhadores incapacitados, de acordo com suas aptidões físicas, e a participação em sua readaptação e em sua reeducação, assim como o assessoramento nesta matéria;

g) o assessoramento para a direção e aos trabalhadores para o destino e a reclassificação dos trabalhadores;

h) os conselhos individuais aos trabalhadores, quando solicitados sobre os transtornos que se manifestam ou se agravam durante o trabalho;

i) os primeiros socorros às vítimas de acidentes ou de indisposição, assim como, em certas circunstâncias e de acordo com as partes interessadas (incluindo ao médico que trata do trabalhador), os tratamentos médicos ambulatoriais para os trabalhadores que não tenham interrompido seu trabalho ou que o tenham de prosseguir;

j) a formação de pessoas encarregadas dos primeiros socorros e sua instrução periódica, assim como a vigilância e a conservação do material de primeiros socorros, em colaboração com os serviços e organismos interessados;

k) a instrução do pessoal da empresa relativa a saúde e a higiene;

1) o estabelecimento e exame periódico de estatísticas sobre o estado sanitário da empresa;

m) os trabalhos de investigação sobre medicina do trabalho ou a participação em tais trabalhos em colaboração com os serviços ou institutos especializados.

9 - Quando uma ou várias das funções enumeradas no parágrafo anterior estiverem garantidas, de conformidade com a legislação ou a prática nacionais, por outros 
serviços apropriados que não forem os de medicina do trabalho, esses serviços deverão proporcionar aos médicos do trabalho todas as informações úteis que estes julgarem conveniente solicitar-lhes.

10 - Os serviços de medicina do trabalho deverão manter estreitas relações com os demais serviços e organismos da empresa interessados nas questões de saúde, de segurança e do bem estar dos trabalhadores, em particular com o serviço social, serviço de segurança, serviço de pessoal, serviços sindicais das empresas, comitês de higiene e segurança, ou qualquer outro comitê ou qualquer pessoa que se ocupe na empresa de questões sanitárias ou sociais.

11 - Os serviços de medicina do trabalho deverão, além do mais, manter estreitas relações com os serviços e organismos exteriores que se dedicam a questões de higiene, de segurança, de reeducação, de readaptação, de reclassificação profissional e de bem estar dos trabalhadores.

12.1 - Os serviços de medicina do trabalho deverão estabelecer, para cada trabalhador, no momento do exame médico de admissão ao empregado e devido a primeira visita feita ao serviço, um expediente médico confidencial e mantê-lo atualizado toda a vez que se efetuem exames ou consultas posteriores.

12.2 - Os serviços de medicina do trabalho deverão, além do mais, registrar convenientemente todos os dados úteis, objetivando poder proporcionar as informações necessárias de suas próprias atividades e sobre o estado de saúde geral dos trabalhadores da empresa, reservadas as disposições previstas no parágrafo 21 .

\section{V - PESSOAL E INSTALAÇÕES}

13 - Da direção do serviço de medicina do trabalho deverá se encarregar um médico, que, segundo os casos, deverá ser diretamente responsável pelo serviço perante a direção da empresa ou perante o organismo do qual depende o serviço.

14 - Os médicos do trabalho não deverão ter sob sua responsabilidade maior número de trabalhadores daquele que lhe permita atender com eficácia, levando-se em consideração os problemas particulares da indústria de que se trata e de suas características.

15 - Os médicos do trabalho deverão gozar de independência profissional e moral completa em relação ao empregador e aos trabalhadores. Para garantir esta independência, a legislação nacional ou os acordos entre as partes ou organizações interessadas deverão dotar aos médicos do trabalho de um estatuto, especialmente no que se refere as suas condições de contratação e de demissão.

16 - O médico encarregado de um serviço de medicina do trabalho deverá, na medida do possível, possuir formação especial em medicina do trabalho ou estar pelo menos familiarizado com a higiene do trabalho, a administração dos primeiros socorros e a patologia do trabalho, assim como com a legislação relacionada com as diferentes 
atividades do serviço. Deve-se proporcionar-lhe a possibilidade de aperfeiçoar-se nestas matérias.

17 - O pessoal de enfermagem agregado aos serviços de medicina do trabalho deverá ter uma qualificação cujas normas deverão ser fixadas por organismo competente.

18 - O pessoal encarregado dos primeiros socorros deverá:

a) estar composto exclusivamente de pessoas devidamente qualificadas; e

b) estar prontamente disponível durante as horas de trabalho.

19 - Os locais e a equipe dos serviços de medicina do trabalho deverão estar de acordo com as normas fixadas pelo organismo competente.

\section{VI - MEIOS DE AÇÃO}

20 - Para poder exercer de forma eficaz suas funções, os serviços de medicina do trabalho deverão:

a) ter livre acesso a todas as instalações auxiliares da empresa e a todos os lugares de trabalho;

b) visitar os locais de trabalho em intervalos adequados, em colaboração, se necessário, com outros serviços da empresa;

c) ser informado sobre os procedimentos empregados, as normas de trabalho e as substâncias utilizadas ou cuja utilização está prevista;

d) ter a possibilidade de efetuar, ou de solicitar que se efetuem por organismos técnicos reconhecidos:

i) averiguações e investigações sobre riscos profissionais que podem ameaçar a saúde; por exemplo, mediante colheita de amostras e análises da atmosfera dos locais de trabalho, dos produtos e das substâncias utilizadas de qualquer outra matéria de suposta nocividade;

ii) o controle dos agentes físicos prejudiciais.

e) ter a possibilidade de pedir às autoridades competentes que fiscalizem o cumprimento das normas de higiene e de segurança no trabalho.

21 - Toda pessoa designada para trabalhar em um serviço de medicina do trabalho, deverá guardar segredo profissional no que se refere, tanto aos dados médicos como aos dados técnicos, que chegam ao seu conhecimento em razão das funções e das atividades enumeradas, reservando-se as excessões previstas pela legislação nacional.

\section{VII - DISPOSIÇÕES GERAIS}

22 - Os trabalhadores e suas organizações deverão colaborar plenamente para lograr as facilidades dos serviços de medicina do trabalho.

23 - As prestações do serviço de medicina do trabalho previstas pela presente Recomendação não deverão ocasionar gasto algum para o trabalhador. 
24 - Sempre que a legislação nacional não disponha outra coisa, e houver falta de acordo entre as partes interessadas, o funcionamento da organização e o funcionamento de um serviço de medicina do trabalho deverão correr a cargo do empregador.

25 - A legislação nacional deverá especificar a autoridade responsável do controle da organização e do funcionamento dos serviços de medicina do trabalho. Em casos apropriados, poderá conferir a função de assessores nesta matéria a serviços técnicos reconhecidos. 


\section{ANEXO 2 \\ ORGANIZAÇÃO INTERNACIONAL DO TRABALHO \\ CONVÊNIO N. ${ }^{\circ} 161$}

\section{Convênio sobre os Serviços de Saúde do Trabalho}

A Conferência Geral da Organização Internacional do Trabalho:

Convocada em Genebra pelo Conselho de Administração do Escritório Internacional do Trabalho e congregada na referida cidade, em 3 de junho de 1985, em sua $71^{\mathrm{a}}$ reunião;

Considerando que a proteção dos trabalhadores contra as doenças, sejam ou não profissionais, e contra os acidentes do trabalho constitui uma das tarefas destinadas à Organização Internacional do Trabalho por sua Constituição;

Recordando os convênios e recomendações internacionais do trabalho na matéria, e em especial a Recomendação sobre a proteção da saúde dos trabalhadores, 1953; a Recomendação sobre os serviços de medicina do trabalho, 1959; o Convênio sobre os representantes dos trabalhadores, 1971, e o Convênio e a Recomendação sobre a segurança e a saúde dos trabalhadores, 1981, que estabeleceu os princípios de uma política nacional e de uma ação a nível nacional;

Depois de haver decidido adotar diversas proposições relativas aos serviços de saúde no trabalho, questão que constitui o quarto ponto da ordem do dia da reunião, e

Depois de haver decidido que as referidas proposições revistam a forma de um convênio internacional, adota, com data de vinte e seis de junho de mil novecentos e oitenta e cinco o presente Convênio que poderá ser citado como o Convênio sobre serviços de saúde no trabalho, 1985.

\section{Parte I}

\section{Princípios de uma Política Nacional}

\section{Artigo 1}

Para os efeitos do presente Convênio:

a) a expressão "serviços de saúde no trabalho" designa aqueles serviços investidos de funções essencialmente preventivas e encarregadas de assessorar o empregador, os trabalhadores e os seus representantes a respeito de:

i) os requisitos necessários para estabelecer e conservar o meio ambiente de trabalho seguro e sadio que favoreça uma saúde física e mental ótima em relação com o trabalho;

ii) a adaptação do trabalho às capacidades dos trabalhadores, considerando o seu estado de saúde física e mental.

b) a expressão "representantes dos trabalhadores na empresa" designa as pessoas reconhecidas como tal em virtude da legislação ou da prática nacionais. 


\begin{abstract}
Artigo 2
À luz das condições e prática nacionais e em consulta com as organizações de empregadores e de trabalhadores mais representativas, quando existam, todo Membro deverá formular, aplicar e reexaminar periodicamente uma política nacional coerente sobre serviços de saúde no trabalho.
\end{abstract}

\title{
Artigo 3
}

1 - Todo o Membro se compromete a estabelecer progressivamente serviços de saúde no trabalho para todos os trabalhadores, incluídos os do setor público e os membros das cooperativas de produção, em todos os ramos de atividade econômica e em todas as empresas. As disposições adotadas deverão ser adequadas e apropriadas aos riscos específicos que prevaleçam nas empresas;

2 - Quando não podem se estabelecer imediatamente os serviços de saúde no trabalho para todas as empresas, todo o Membro deverá elaborar planos para o estabelecimento de tais serviços, em consulta com as organizações de empregadores e de trabalhadores mais representativas, quando existam;

3 - Todo o Membro interessado deverá indicar, no primeiro relatório sobre a aplicação do Convênio que submeta em virtude do artigo 22 da Constituição da Organização Internacional do Trabalho, os planos que elaborou de conformidade com o $\S 2 .^{\circ}$ do presente artigo, e expor em relatórios ulteriores todo o progresso realizado em sua aplicação.

\section{Artigo 4}

A autoridade competente deverá consultar as organizações de empregadores e de trabalhadores mais representativas, quando existam, a respeito das medidas que é preciso adotar para tornar efetivas as disposições do presente Convênio.

\section{Parte II}

\section{Funções}

\section{Artigo 5}

Sem prejuízo da responsabilidade de cada empregador com respeito a saúde e a segurança dos trabalhadores a quem emprega, e considerando a necessidade de que os trabalhadores participem em matéria de saúde e de segurança no trabalho, os serviços de saúde no trabalho deverão garantir as funções seguintes que sejam adequadas e apropriadas aos riscos da empresa para a saúde no trabalho:

a) identificação e avaliação dos riscos que possam prejudicar a saúde no local de trabalho;

b) vigilância dos fatores do meio ambiente de trabalho e das práticas de trabalho que possam afetar a saúde dos trabalhadores, incluídas as instalações sanitárias, 
restaurantes e alojamentos, quando estas facilidades sejam proporcionadas pelo empregador;

c) assessoramento sobre o planejamento e a organização do trabalho, incluído o desenho dos locais de trabalho, sobre a seleção, a manutenção e o estado das máquinas e dos equipamentos e sobre as substâncias utilizadas no trabalho;

d) participação no desenvolvimento de programas para o melhoramento das práticas de trabalho, assim como nas provas e na avaliação de novos equipamentos, em relação com a saúde;

e) assessoramento em matéria de saúde, de segurança e de higiene no trabalho e de ergonomia, assim como em matéria de equipamentos de proteção individual e coletiva;

f) vigilância da saúde dos trabalhadores em relação com o trabalho;

g) fomento da adaptação do trabalho aos trabalhadores;

h) assistência em prol da adoção de medidas de reabilitação profissional;

i) colaboração na difusão de informações na formação e educação em matéria de saúde e higiene no trabalho e de ergonomia;

j) organização dos primeiros socorros e dos atendimentos de urgência;

k) participação na análise dos acidentes do trabalho e das doenças profissionais.

\section{Parte III}

\section{Organizacão}

\section{Artigo 6}

Para o estabelecimento dos serviços de saúde no trabalho deverão adotar-se disposições:

a) por via legislativa;

b) por convênios coletivos ou outros acordos entre os empregadores e os trabalhadores; ou

c) de qualquer outra maneira de acordo com a autoridade competente, após prévia consulta com as organizações representativas de empregadores e de trabalhadores interessados.

\section{Artigo 7}

1 - Os serviços de saúde no trabalho podem ser organizados, segundo os casos, como serviços para uma só empresa ou como serviços comuns a várias empresas.

2 - De conformidade com as condições e a prática nacionais, os serviços de saúde no trabalho poderão ser organizados:

a) por poderes públicos ou serviços oficiais;

b) por empresas ou grupos de empresas interessadas;

c) pelas instituições de seguridade social;

d) por qualquer outro organismo habilitado pela autoridade competente; 
e) por uma combinação de qualquer das formas anteriores.

\section{Artigo 8}

O empregador, os trabalhadores e seus representantes, quando existam, deverão cooperar e participar na aplicação de medidas relativas a organização e demais aspectos dos serviços de saúde no trabalho, sobre base eqüitativa.

\section{Parte IV}

\section{Condições de Funcionamento}

\section{Artigo 9}

1- De conformidade com a legislação e a prática nacionais, os serviços de saúde no trabalho deverão ser multidisciplinares. A composição do pessoal deverá ser determinada em função da índole das tarefas que devam ser executadas.

2 - Os serviços de saúde no trabalho deverão cumprir funções em cooperação com os demais serviços da empresa.

3 - De conformidade com a legislação e a prática nacionais, deverão ser tomadas medidas para garantir a adequada cooperação e coordenação entre os serviços de saúde no trabalho e, quando for conveniente, com outros serviços envolvidos na outorgação das prestações relativas a saúde.

\section{Artigo 10}

O pessoal que preste serviço de saúde no trabalho deverá gozar de plena independência profissional, tanto em relação ao empregador como dos trabalhadores e de seus representantes quando existam, em relação com as funções estipuladas no artigo 5.

\section{Artigo 11}

A autoridade competente deverá determinar as qualificações que se exijam do pessoal que irá prestar serviços de saúde no trabalho, segundo a característica das funções que deva desempenhar e de conformidade com a legislação e da prática nacionais.

\section{Artigo 12}

A vigilância da saúde dos trabalhadores em relação com o trabalho não deverá significar para eles nenhuma perda de salários, deverá ser gratuita e, na medida do possível, realizar-se durante as horas de trabalho.

\section{Artigo 13}


Todos os trabalhadores deverão ser informados dos riscos para a saúde que intimamente se relacionem com seu trabalho.

\section{Artigo 14}

O empregador e os trabalhadores deverão informar aos serviços de saúde no trabalho de todo o fator conhecido e de todo o fator suspeito no meio ambiente de trabalho que possa afetar a saúde dos trabalhadores.

\section{Artigo 15}

Os serviços de saúde do trabalho deverão ser informados dos casos de doença entre os trabalhadores e das ausências ao trabalho por razões de saúde, a fim de poder identificar qualquer relação entre as causas da doença ou da ausência e os riscos para a saúde que podem apresentar-se nos locais de trabalho. Os empregadores não devem encarregar o pessoal dos serviços de saúde do trabalho que verifiquem as causas da ausência do trabalho.

\section{Parte V}

\section{Disposições Gerais}

\section{Artigo 16}

Uma vez estabelecidos os serviços de saúde do trabalho, a legislação nacional deverá designar a autoridade ou autoridades encarregadas de supervisionar seu funcionamento e assessorá-los.

\section{Artigo 17}

As ratificações formais do presente Convênio serão comunicadas, para seu registro, ao Diretor Geral do Escritório Internacional do Trabalho.

\section{Artigo 18}

1 - Este Convênio obrigará unicamente aqueles Membros da Organização Internacional do Trabalho cujas ratificações tenham sido registradas pelo Diretor Geral.

2 - Entrará em vigor doze meses após a data em que as ratificações dos Membros tenham sido registrados pelo Diretor Geral.

3 - A partir deste momento, este Convênio entrará em vigor, para cada Membro, doze meses após a data em que tenha sido registrada sua ratificação.

\section{Artigo 19}

1 - Todo o Membro que tenha ratificado este Convênio poderá denunciá-lo ao término de um período de dez anos, a partir da data em que se tenha colocado 
inicialmente em vigor, mediante ata comunicada, para seu registro, ao Diretor Geral do Escritório Internacional do Trabalho. A denúncia não surtirá efeito até um ano depois da data em que se tenha registrado.

2 - Todo o Membro que tenha ratificado este Convênio e que, no prazo de um ano depois da expiração do período de dez anos mencionado no parágrafo precedente, não faça uso do direito de denúncia previsto neste artigo, ficará obrigado durante um novo período de dez anos, e no sucessivo poderá denunciar este Convênio na expiração de cada período de dez anos, nas condições previstas neste artigo.

\section{Artigo 20}

1 - O Diretor Geral do Escritório Internacional do Trabalho notificará a todos os Membros da Organização Internacional do Trabalho o registro de quantas ratificações, declarações e denúncias que são comunicadas pelos Membros da Organização.

2 - Ao notificar os Membros da Organização o registro, da segunda ratificação que lhe tenha sido comunicada, o Diretor Geral chamará a atenção dos Membros da Organização sobre a data em que entrará em vigor o presente Convênio.

\section{Artigo 21}

O Diretor Geral do Escritório Internacional do Trabalho comunicará ao Secretário Geral das Nações Unidas para efeito de registro e de conformidade com o artigo io2 da Carta das Nações Unidas, uma informação completa sobre todas as ratificações, declarações e atas de denúncia que tenha registrado de acordo com os artigos precedentes.

\section{Artigo 22}

Cada vez que o considere necessário, o Conselho de Administração do Escritório Internacional do Trabalho apresentará para a Conferência memorial sobre a aplicação do Convênio, e considerará a conveniência de incluir na ordem do dia da Conferência a questão de sua revisão total ou parcial.

\section{Artigo 23}

1 - No caso de que a Conferência adote um novo convênio que implique revisão total ou parcial do presente, e a menos que o novo convênio contenha dispositivos em contrário:

a) a ratificação, por um Membro, de novo convênio revisor implicará, ipso jure, na denúncia imediata deste Convênio, não obstante as disposições contidas no artigo 19, sempre que o novo convênio revisor tenha entrado em vigor;

b) a partir da data em que entre em vigor o novo convênio revisor, o presente Convênio cessará de estar aberto para a ratificação pelos Membros, 
2 - Este Convênio continuará em vigor em todo o caso, em sua forma e contendo atuais, para os Membros que o tenham ratificado e não ratifiquem o convênio revisor,

\section{Artigo 24}

As versões inglesa e francesa do texto deste Convênio são igualmente autênticas. 


\section{ANEXO 3 \\ ORGANIZAÇÃO INTERNACIONAL DO TRABALHO \\ RECOMENDAÇÃO N. ${ }^{\circ} 171$}

\section{Recomendação sobre os Serviços de Saúde do Trabalho}

A Conferência Geral da Organização Internacional do Trabalho:

Convocada em Genebra pelo Conselho de Administração do Escritório Internacional do Trabalho e congregada na referida cidade, em 7 de junho de 1985, em sua $71^{\mathrm{a}}$ reunião;

Considerando que a proteção dos trabalhadores contra as doenças sejam ou não profissionais e contra os acidentes do trabalho constitui uma das tarefas destinadas à Organização Internacional do Trabalho por sua Constituição;

Recordando os convênios e recomendações internacionais do trabalho na matéria, em especial a Recomendação sobre a proteção da saúde dos trabalhadores, 1953; a Recomendação sobre os serviços de medicina do trabalho, 1959; o Convênio sobre os representantes dos trabalhadores, 1971, e o Convênio e a Recomendação sobre segurança

e saúde dos trabalhadores, 1981, que estabelecem os princípios de uma política nacional e de uma ação a nível nacional; e a Declaração tripartite de princípios sobre as empresas multinacionais e a política social adotada pelo Conselho de Administração do Escritório Internacional do Trabalho;

Depois de ter decidido adotar diversas proposições relativas aos serviços de saúde no trabalho, questão que constitui o quarto ponto da ordem do dia da reunião, e Depois de ter decidido que as referidas proposições revistam a forma de uma recomendação que complete o Convênio sobre serviços de saúde no trabalho, 1985.

Adota, com data de vinte e seis de junho de mil novecentos e oitenta e cinco, a presente Recomendação, que poderá ser citada como a Recomendação sobre os serviços de saúde no trabalho, 1985.

\section{I - PRINCÍPIOS DE UMA POLÍTICA NACIONAL}

1 - De conformidade com as condições e prática nacionais e em consulta com as organizações de empregadores e de trabalhadores mais representativas, quando existam, todo o Membro deveria formular, aplicar e reexaminar periodicamente uma política nacional coerente sobre serviços de saúde no trabalho, incluídos os princípios gerais de suas funções, de sua organização e de seu funcionamento.

2.1 - Todo o Membro deveria estabelecer progressivamente serviços de saúde no trabalho para todos os trabalhadores, incluídos os do setor público e os membros das cooperativas de produção, em todos os ramos de atividades econômicas e em todas as empresas. As disposições adotadas deveriam ser adequadas e apropriadas aos riscos específicos para a saúde que prevalecem nas empresas,

2.2 - Na medida em que seja necessário e praticamente realizável, deveriam adotar-se também disposições para facilitar aos trabalhadores independentes uma proteção 
análoga aquela prevista no Convênio sobre os serviços de saúde no trabalho, 1985, e na presente Recomendação.

\section{II - FUNÇÕES}

3 - A função dos serviços de saúde no trabalho deveria ser essencialmente preventiva.

4 - Os serviços de saúde no trabalho deveriam estabelecer um programa de atividades adaptado à empresa ou às empresas das quais servem principalmente em função dos riscos profissionais que se apresentam nos locais de trabalho e dos problemas específicos que se estabelecem nos respectivos ramos de atividade econômica.

\section{A - VIGILÂNCIA DO MEIO AMBIENTE DE TRABALHO}

5.1 - A vigilância do meio ambiente deverá compreender:

a) a identificação e avaliação dos fatores do meio ambiente de trabalho que possam afetar a saúde dos trabalhadores;

b) a avaliação das condições de higiene do trabalho e dos fatores da organização do trabalho que possam ocasionar riscos para a saúde dos trabalhadores;

c) a avaliação dos meios de proteção coletiva e individual;

d) a avaliação, quando seja apropriado, da exposição dos trabalhadores aos agentes nocivos, mediante métodos de controle válidos e geralmente aceitos;

e) a verificação dos sistemas de controle destinados a eliminar ou reduzir a exposição.

5.2 - A referida vigilância deverá ser levada a termo em relação com os demais serviços técnicos da empresa e com a cooperação dos trabalhadores interessados e de seus representantes na empresa ou do comitê de segurança e higiene quando existam.

6.1 - De conformidade com a legislação e a prática nacionais, os dados resultantes da vigilância do local de trabalho deverá consignar-se em forma apropriada e manter-se à disposição do empregador, dos trabalhadores e de seus representantes na empresa ou do comitê de segurança e higiene, quando existam.

6.2 - Tais dados deverão ser utilizados respeitando seu caráter confidencial, e somente para orientar e dar assessoramento a respeito das medidas destinadas a melhorar o meio ambiente de trabalho, a saúde e a segurança dos trabalhadores.

6.3 - A autoridade competente deverá ter acesso a estes dados, os quais o serviço de saúde no trabalho somente deverá comunicar a terceiros após prévio acordo do empregador, dos trabalhadores e de seus representantes na empresa ou do comitê de segurança e higiene, se os tiver.

7 - A vigilância do meio ambiente de trabalho deverá compreender as visitas do pessoal de serviços de saúde no trabalho que sejam necessárias para examinar os fatores do meio ambiente de trabalho susceptíveis de prejudicar a saúde dos 
trabalhadores, a salubridade do meio ambiente de trabalho e as condições de trabalho.

8 - Os serviços de saúde no trabalho deverão:

a) efetuar quando necessário, a vigilância da exposição dos trabalhadores a riscos especiais para a saúde;

b) supervisionar as instalações sanitárias e outras instalações colocadas à disposição dos trabalhadores pelo empregador tais como a administração de água potável, cantina e alojamento;

c) assessorar à respeito das possíveis incidências na saúde dos trabalhadores, pela utilização de tecnologias;

d) participar e assessorar na seleção dos equipamentos necessários para a proteção individual dos trabalhadores contra os riscos profissionais;

e) colaborar na análise dos postos de trabalho e no estudo da organização do trabalho e dos métodos de trabalho, a fim de garantir uma melhor adaptação do trabalho aos trabalhadores;

f) participar na análise dos acidentes do trabalho e das doenças profissionais e nos programas de prevenção de acidentes.

9 - O pessoal que prestar serviços de saúde no trabalho deverá, depois de informado ao empregador, aos trabalhadores e ao seus representantes quando for apropriado:

a) ter livre acesso a todos os locais de trabalho e às instalações que a empresa facilitar para os trabalhadores;

b) ter acesso às informações sobre métodos, normas de trabalho, materiais e substâncias ou cuja utilização esteja prevista, sob reserva de que se preserve o segredo de toda a informação de índole confidencial que se consiga e que não concerne a saúde dos trabalhadores;

c) poder recolher amostras, para fins de análise dos produtos, materiais e substâncias utilizadas ou manipuladas.

10 - O serviço de saúde no trabalho deveria ser consultado sobre qualquer modificação prevista em matéria de métodos e condições de trabalho susceptível de ter algum efeito sobre a saúde ou a segurança dos trabalhadores.

\section{B - VIGILÂNCIA DA SAÚDE DOS TRABALHADORES}

11.1 - A vigilância da saúde dos trabalhadores deverá atingir, nos casos e segundo as condições que defina a autoridade competente, todas as avaliações necessárias para proteger a saúde dos trabalhadores que possam incluir:

a) uma avaliação da saúde dos trabalhadores antes de que se lhes indiquem tarefas específicas que possam apresentar um perigo para sua saúde ou para os demais;

b) avaliação da saúde em intervalos periódicos durante todo o emprego que implique uma exposição a riscos particulares para a saúde;

c) uma avaliação da saúde dos trabalhadores que retornam ao trabalho após uma ausência prolongada por motivos de saúde, com a finalidade de descobrir eventuais 
origens profissionais, de recomendar uma ação apropriada para proteger aos trabalhadores e de determinar a adaptabilidade dos trabalhadores às suas tarefas e a necessidade de uma reclassificação e de uma readaptação;

d) avaliações da saúde ao terminar e depois de terminar atribuições em posto de trabalho que apresentam riscos susceptíveis de provocar prejuízos ulteriores para a saúde ou de contribuir para tais prejuízos.

11.2 - Deveriam adotar-se disposições para proteger a intimidade dos trabalhadores e procurar que a vigilância de sua saúde não seja utilizada com fins discriminatórios nem de nenhuma outra maneira prejudicial para seus interesses,

12.1 - Quando os trabalhadores estão expostos a riscos profissionais específicos, a vigilância de seu estado de saúde deverá compreender, quando necessário, além dos exames de saúde previstos no $\S 11$ da presente Recomendação, todos os exames e investigações necessários para detectar os níveis de exposição e as reações e os efeitos biológicos precoces.

12.2 - Quando existe um método válido e geralmente aceito de vigilância biológica da saúde dos trabalhadores para a detecção precoce dos efeitos sobre a saúde da exposição a riscos profissionais específicos, poderá utilizar-se o referido método para identificar nos trabalhadores que requerem um exame médico detalhado, sujeito ao consentimento individual do trabalhador.

13 - Os serviços de saúde no trabalho deverão ser informados dos casos de doenças entre os trabalhadores e das ausências ao trabalho por razões de saúde, a fim de poderem identificar qualquer relação entre as causas da doença ou da ausência e os riscos para a saúde que possam se apresentar nos locais de trabalho. O pessoal encarregado dos serviços de saúde no trabalho não deverá ser obrigado pelos empregadores a verificar as razões das ausências ao trabalho.

14.1 - Os serviços de saúde no trabalho deverão registrar os dados relativos a saúde dos trabalhadores em expedientes individuais de saúde e confidenciais. Os referidos expedientes deverão também conter informações à respeito das tarefas que tenham realizado os trabalhadores, de sua exposição aos riscos profissionais inerentes ao seu trabalho e dos resultados de toda a avaliação da exposição dos trabalhadores a tais riscos.

14.2 - O pessoal que presta serviços de saúde no trabalho somente deverá ter acesso aos expedientes de saúde se as informações neles contidas tenham relação com o cumprimento de suas funções. Quando os expedientes contenham informações pessoais de caráter médico confidencial, este acesso deve limitar-se ao pessoal médico.

14.3 - Os dados pessoais relativos a avaliação do estado de saúde somente deverão ser comunicados à terceiros após prévio consentimento do trabalhador devidamente informado. 
15 - A legislação nacional, a autoridade competente ou a prática nacionais baseadas em pautas de ética reconhecidas deverão prescrever as condições e o período de conservação dos expedientes pessoais de saúde, as condições relativas a transmissão e comunicação de tais expedientes e as medidas necessárias para preservar seu caráter confidencial, em particular quando as informações que contenham são registradas em computador.

16.1 - Ao término de exame médico prescrito para determinar a aptidão de um trabalhador para posto de trabalho que exige exposição a risco determinado, o médico que o tenha realizado deverá comunicar suas conclusões por escrito ao trabalhador e ao empregador.

16.2 - Esta declaração não deverá conter indicação alguma de caráter médico; segundo os casos, poderá indicar que o trabalhador é apto para o posto de trabalho previsto ou bem especificar os tipos de trabalho e as condições de trabalho que forem contra indicados, temporário ou permanente, desde um ponto de vista médico.

17 - Quando a manutenção de um trabalhador em posto de trabalho, está contra indicada por motivos de saúde, os serviços de saúde no trabalho deverão colaborar nos esforços destinados a encontrar-lhe outra colocação na empresa ou outra solução apropriada.

18 - Quando a vigilância da saúde tenha permitido detectar uma doença profissional, esta deverá ser notificada para a autoridade competente de conformidade com a legislação e a prática nacionais. $O$ empregador, os trabalhadores e seus representantes deverão ser informados de que a referida notificação foi efetuada.

\section{C - INFORMAÇÃO, EDUCAÇÃO, FORMAÇÃO, ASSESSORAMENTO}

19 - Os serviços de saúde no trabalho deverão participar na elaboração e aplicação de programas de informação, de educação e de formação, destinados ao pessoal da empresa, sobre questões de saúde e higiene relacionados com o trabalho.

20 - Os serviços de saúde no trabalho deverão participar na informação e o aperfeiçoamento periódico do pessoal de primeiros socorros e na formação gradual e contínua de todo o pessoal da empresa que contribui para a segurança e a saúde no trabalho.

21 - A fim de fomentar a adaptação do trabalho aos trabalhadores e o melhor das condições e meio ambiente de trabalho, os serviços de saúde no trabalho deverão assumir a função de assessores do empregador, dos trabalhadores e de seus representantes na empresa e do comitê de segurança e higiene do trabalho e da ergonomia, e deverão colaborar com os organismos que já atuam como assessores nesta esfera.

22.1 - Todo o trabalhador deverá ser informado, de maneira conveniente e adequada dos riscos para a saúde que apresenta o seu trabalho, e dos resultados dos exames de saúde de que tenha sido objeto e da avaliação de seu estado de saúde. 
22.2 - Todo o trabalhador terá o direito de que se corrija qualquer dado que seja errôneo ou que possa induzir em erro.

22.3 - Os serviços de saúde no trabalho deverão além do mais de assessorar individualmente os trabalhadores à respeito de sua saúde em relação com o seu trabalho.

\section{D - ATENDIMENTOS DE URGÊNCIA, TRATAMENTOS E PROGRAMAS DE SAÚDE}

23 - Considerando-se a legislação e prática nacionais, os serviços de saúde no trabalho nas empresas deverão proporcionar os atendimentos de urgência e as consultas de urgência aos trabalhadores vítimas de acidentes ou de indisposição no local de trabalho e colaborar na organização da administração dos atendimentos de urgência.

24 - Considerando-se a organização da medicina preventiva a nível nacional, os serviços de saúde no trabalho deverão, quando possível e apropriado:

a) proceder imunizações em relação aos riscos biológicos que se apresentam nos locais de trabalho;

b) participar em campanhas de proteção da saúde;

c) colaborar com as autoridades sanitárias nos programas de saúde pública.

25 - Considerando-se a legislação e a prática nacionais e a prévia consulta com as organizações de empregadores e de trabalhadores mais representativas, quando existam, a autoridade competente, se for necessário, deverá autorizar os serviços de saúde no trabalho, de acordo com todos os interessados, incluído o próprio trabalhador e seu médico particular, ou um serviço de cuidados primários da saúde, quando seja possível sua aplicação, a assumir uma ou várias das funções seguintes, ou a participar nelas:

a) o tratamento dos trabalhadores que não tenham interrompido seu trabalho ou que tenham se reintegrado ao mesmo após uma ausência;

b) o tratamento das vítimas de acidentes de trabalho;

c) o tratamento das doenças profissionais e das afecções agravadas pelo trabalho;

d) os aspectos médicos da reeducação e reabilitação profissionais.

26 - Considerando-se a legislação e a prática nacionais em matéria de organização da assistência à saúde e do afastamento dos centros que a dispensam, os serviços de saúde no trabalho poderão desenvolver outras atividades relacionadas com a saúde, incluída a assistência médica curativa aos trabalhadores e a suas famílias na forma que permita a autoridade competente em consulta com as organizações de empregadores e de trabalhadores, mais representativas, quando existam. 
27 - Os serviços de saúde no trabalho deverão cooperar com os demais serviços interessados na elaboração de planos de urgência para fazer frente aos acidentes importantes.

\section{E - OUTRAS FUNÇÕES}

28 - Os serviços de saúde no trabalho deverão analisar os resultados da vigilância da saúde dos trabalhadores e do meio ambiente de trabalho e os resultados da vigilância biológica e da vigilância individual contínua da exposição dos trabalhadores a determinados riscos profissionais, quando estes existam, a fim de avaliar as possíveis relações entre a exposição aos riscos profissionais e os prejuízos para a saúde, e de propor medidas encaminhadas a melhorar as condições e o meio ambiente de trabalho.

29 - Os serviços de saúde no trabalho deverão elaborar planos e, a intervalos apropriados, relatórios sobre suas atividades e as condições de saúde na empresa. Estes planos e relatórios deverão ser colocados à disposição do empregador e dos representantes dos trabalhadores na empresa ou do comitê de segurança e higiene, quando existam, e a autoridade competente deverá ter acesso aos mesmos,

30.1 - De acordo com os seus recursos, os serviços de saúde no trabalho, em consulta com os representantes dos empregadores e dos trabalhadores, deverão contribuir na investigação, participando em estudos ou pesquisas efetuados a nível da empresa ou do ramo de atividade econômica por exemplo, com objetivo de reunir informação epidemiológica e orientar suas atividades.

30.2 - Os resultados das medições realizadas na vigilância,do meio ambiente de trabalho e os resultados das avaliações de saúde dos trabalhadores poderão ser utilizados com finalidade de investigação, sob reserva das disposições dos $\S \S 6.3 \mathrm{e}$ 14.3, da presente Recomendação.

31 - Os serviços de saúde no trabalho deverão participar com outros serviços da empresa, quando assim convier, nas medidas encaminhadas para impedir que as atividades desta ocasionem prejuízo ao meio ambiente geral.

\section{III - ORGANIZAÇÃO}

32 - Na medida do possível, os serviços de saúde no trabalho deverão estar situados no local de trabalho ou nas proximidades deste, ou estar bem organizados de forma que seja garantido o desempenho de suas funções no local de trabalho,

33.1 - Os empregadores, os trabalhadores e seus representantes, se os tenham, deverão cooperar e participar na aplicação das medidas relativas a organização e demais aspectos dos serviços de saúde no trabalho sobre base equiitativa.

33.2 - De conformidade com as condições e a prática nacionais, os empregadores e os trabalhadores, ou seus representantes na empresa, ou o comitê de segurança e higiene quando existam, deverão participar nas decisões sobre organização e 
funcionamento destes serviços, incluídas as relativas ao emprego do pessoal e a planificação dos programas do serviço.

34.1 - Os serviços de saúde no trabalho podem ser organizados segundo os casos, como serviços para uma empresa somente ou como serviços comuns a várias empresas.

34.2 - De conformidade com as condições e a prática nacionais, os serviços de saúde no trabalho podem ser organizados por:

a) as empresas ou grupo de empresas interessadas;

b) os poderes públicos ou os serviços oficiais;

c) as instituições de seguridade social;

d) qualquer outro organismo habilitado pela autoridade competente;

e) uma combinação de qualquer das fórmulas anteriores.

34.3 - A autoridade competente deverá precisar as circunstâncias quando os serviços de saúde no trabalho ainda não estão organizados, para que os serviços adequados existentes possam ser reconhecidos provisoriamente como organismos habilitados no sentido de subparágrafo 2 supra.

35 - Nos casos em que a autoridade competente, após consultar as organizações de empregadores e de trabalhadores representativas interessadas, quando existam, determine que o estabelecimento de um serviço de saúde no trabalho ou o acesso a tal serviço é praticamente impossível, as empresas deverão, em caráter provisório e após consultar os representantes dos trabalhadores na empresa ou o comitê de segurança e higiene, quando existam, estabelecer acordo com um serviço médico da localidade para proceder aos exames de saúde prescritos pela legislação nacional, controlar as condições sanitárias existentes na empresa e fiscalizar, para que os primeiros socorros e as consultas de urgência estejam organizadas de forma adequada.

\section{IV - CONDIÇÕES DE FUNCIONAMENTO}

36.1 - De conformidade com a legislação e prática nacionais, os serviços de saúde no trabalho deverão estar formados por equipes multidisciplinares constituídas em função da característica das tarefas que devam ser executadas.

36.2 - Os serviços de saúde no trabalho deverão dispor de pessoal técnico em número suficiente, com formação especializada e experiências em esferas tais como a medicina do trabalho, a higiene do trabalho, a ergonomia, os cuidados de enfermagem do trabalho e outras questões correlatas. Este pessoal deverá, na máxima medida possível, manter-se conhecedor dos progressos nos conhecimentos científicos e técnicos necessários para o cumprimento de suas funções e ter possibilidade de adquiri-los sem prejuízo de seu salário.

36.3 - Os serviços de saúde no trabalho deverão, além do mais, dispor de pessoal administrativo necessário para o se/u funcionamento. 
37.1 - Deverá ser salvaguardada a independência profissional do pessoal que presta serviço em matéria de saúde no trabalho, de conformidade com a prática e a legislação nacionais. Isto poderá ser alcançado mediante leis, regulamentos e consultas apropriadas entre o empregador, os trabalhadores e seus representantes e os comitês de segurança e higiene, se existirem.

37.2 - A autoridade competente deverá especificar, quando proceder, de conformidade com a legislação e prática nacionais, as condições relativas a contratação e o. término do emprego do pessoal dos serviços de saúde no trabalho, em consulta com as organizações representativas de trabalhadores e de empregadores interessados.

38 - Reservadas as exceções que prevêem as leis e os regulamentos nacionais todo o pessoal de um serviço de saúde no trabalho deverá estar obrigado a guardar segredo profissional sobre os dados médicos e técnicos que chequem a conhecer em razão de suas funções e das atividades do serviço.

39.1 - A autoridade competente poderá prescrever normas relativas aos locais e à equipe necessárias para o funcionamento dos serviços de saúde no trabalho.

39.2 - Os serviços de saúde no trabalho deverão dispor de instalações adequadas para efetuar as análises e provas necessárias para a vigilância da saúde dos trabalhadores e a salubridade do meio ambiente de trabalho.

40.1 - Dentro do enfoque multidisciplinar, os serviços de saúde no trabalho deverão colaborar com:

a) os serviços que se ocupam da segurança dos trabalhadores na empresa;

b) os distintos serviços ou unidades de produção para ajudá-los a formular e para aplicar programas preventivos convenientes;

c) o departamento de pessoal da empresa e us demais serviços interessados;

d) os representantes dos trabalhadores na empresa como também seus representantes de segurança e o comitê de segurança e higiene, se os tenha.

2 - Quando for apropriado, os serviços de saúde no trabalho e os serviços de segurança no trabalho poderão ser organizados conjuntamente.

41 - Além disso, os serviços de saúde no trabalho deverão manter contatos, quando necessário, com os serviços e organismos externos à empresa que se ocupam de questões relativas à saúde, à higiene, à segurança, à readaptação, ao readestramento e reclassificação profissional e às condições de trabalho e de bem-estar dos trabalhadores, assim como com os serviços de inspeção e o organismo nacional que tenha sido designado para participar no Sistema Internacional de Alerta para a segurança e a saúde dos trabalhadores estabelecido pela Organização Internacional do Trabalho. 
42 - A pessoa encarregada de um serviço de saúde no trabalho deverá poder, de conformidade com as disposições do $\S 38$, consultar a autoridade competente, tendo antes informado ao empregador e aos representantes dos trabalhadores na empresa ou ao comitê de segurança e higiene se os possua, à respeito da aplicação das normas de segurança e higiene do trabalho na empresa.

43 - Os serviços de saúde no trabalho de toda a empresa nacional ou multinacional que conte com mais de um estabelecimento, deverão prestar o nível máximo de serviços sem discriminações, aos trabalhadores de todos os estabelecimentos, qualquer que for o lugar ou o país em que estejam situados.

\section{V - DISPOSIÇÕES GERAIS}

44.1 - Sendo de sua responsabilidade a segurança e a saúde dos trabalhadores que empregam, os empregadores deverão adotar todas as disposições necessárias para facilitar o cumprimento das funções dos serviços de saúde no trabalho.

2 - Os trabalhadores e suas organizações deverão proporcionar seu apoio aos serviços de saúde no trabalho para o cumprimento de suas funções.

45 - As prestações relacionadas com a saúde no trabalho dispensadas pelos serviços de saúde no trabalho deverão ser totalmente gratuitas para os trabalhadores.

46 - Quando os serviços de saúde no trabalho tenham sido estabelecidos e suas funções fixadas pela legislação nacional, esta deverá determinar também a forma de financiar tais serviços.

47 - Para os efeitos da presente Recomendação, a expressão "representantes dos trabalhadores na empresa" designa as pessoas reconhecidas como tal pela legislação ou prática nacionais,

48 - A presente Recomendação, que completa o Convênio sobre os Serviços de saúde no trabalho, 1985, substitui a Recomendação sobre os serviços de medicina do trabalho, 1959. 


\section{ANEXO 4 \\ NR 4 - SERVIÇOS ESPECIALIZADOS EM ENGENHARIA DE SEGURANÇA E EM MEDICINA DO TRABALHO}

4.1 As empresas privadas e públicas, os órgãos públicos da administração direta e indireta e dos poderes Legislativo e Judiciário, que possuam empregados regidos pela Consolidação das Leis do Trabalho - CLT manterão, obrigatoriamente, Serviços Especializados em Engenharia de Segurança e em Medicina do Trabalho, com a finalidade de promover a saúde e proteger a integridade do trabalhador no local de trabalho.

4.2 O dimensionamento dos Serviços Especializados em Engenharia de Segurança e em Medicina do Trabalho vincula-se à gradação do risco da atividade principal e ao número total de empregados do estabelecimento constantes dos Quadros 1 e II anexos, observadas as exceções previstas nesta NR.

4.2.1. Para fins de dimensionamento, os canteiros de obras e as frentes de trabalho com menos de 1.000 (um mil) empregados e situados no mesmo Estado, Território ou Distrito Federal não serão considerados como estabelecimentos, mas como integrantes da empresa de engenharia principal responsável, a quem caberá organizar os Serviços Especializados em Engenharia de Segurança e em Medicina do Trabalho.

4.2.1.1. Neste caso, os engenheiros de segurança do trabalho, os médicos do trabalho e os enfermeiros do trabalho poderão ficar centralizados.

4.2.1.2. Para os técnicos de segurança do trabalho e auxiliares de enfermagem do trabalho, o dimensionamento será feito por canteiro de obra ou frente de trabalho, conforme o Quadro II, anexo.

4.2.2. As empresas que possuam mais de $50 \%$ (cinqüenta por cento) de seus empregados em estabelecimento ou setor com atividade cuja gradação de risco seja de grau superior ao da atividade principal deverão dimensionar os Serviços Especializados em Engenharia de Segurança e em Medicina do Trabalho em função do maior grau de risco, obedecido o disposto no Quadro II desta NR.

4.2.3. A empresa poderá constituir Serviço Especializado em Engenharia de Segurança e em Medicina do Trabalho centralizado para atender a um conjunto de estabelecimentos pertencentes a ela, desde que a distância a ser percorrida entre aquele em que se situa o serviço e cada um dos demais não ultrapasse a $5.000 \mathrm{~m}$ (cinco mil metros), dimensionando-o em função do total de empregados e do risco, de acordo com o Quadro II anexo e o subitem 4.2.2.

4.2.4. Havendo, na empresa, estabelecimento(s) que se enquadre(m) no Quadro II, desta NR, e outro(s) que não se enquadre(m), a assistência a este(s) será feita 
pelos serviços especializados daquele(s) dimensionados conforme os subitens 4.2.5.1 e 4.2.5.2 e desde que. localizados no mesmo Estado, Território ou Território Federal.

4.2.5. Havendo, na mesma empresa, apenas estabelecimentos que, isoladamente, não se enquadrem no Quadro II anexo, o cumprimento desta NR será-feito através de Serviços Especializados em Engenharia de Segurança e em Medicina do Trabalho centralizados em cada Estado, Território ou Distrito Federal, desde que o total de empregados dos estabelecimentos no Estado, Território ou Distrito Federal alcance os limites previstos no Quadro II anexo, aplicado o disposto no subitem 4.2.2.

4.2.5.1. Para as empresas enquadradas no grau de risco 1 o dimensionamento dos serviços referidos no subitem 4.2.5. obedecerá ao Quadro II anexo, considerando-se como número de empregados o somatório dos empregados existentes no estabelecimento que possua o maior número e a média aritmética do número de empregados dos demais estabelecimentos, devendo todos os profissionais integrantes dos Serviços Especializados em Engenharia de Segurança e em Medicina do Trabalho, assim constituídos, cumprirem tempo integral.

4.2.5.2. Para as empresas enquadradas nos graus de risco 2,3 e 4 o dimensionamento dos serviços referidos no subitem 4.2.5 obedecerá ao Quadro II anexo, considerando-se como número de empregados o somatório dos empregados de todos os estabelecimentos.

4.3. As empresas enquadradas no grau de risco 1 obrigadas a constituir Serviços Especializados em Engenharia de Segurança e em Medicina do Trabalho e que possuam outros serviços de medicina e engenharia poderão integrar estes serviços com os Serviços Especializados em Engenharia de Segurança e em Medicina do Trabalho constituindo um serviço único de engenharia e medicina.

4.3.1. As empresas que optarem pelo serviço único de engenharia e medicina ficam obrigadas a elaborar e submeter à aprovação da Secretaria de Segurança e Medicina do Trabalho, até o dia 30 de março, um programa bienal de segurança e medicina do trabalho a ser desenvolvido.

4.3.1.1. As empresas novas que se instalarem após o dia 30 de março de cada exercício poderão constituir o serviço único de que trata o subitem 4.3.1 e elaborar o programa respectivo a ser submetido à Secretaria de Segurança e Medicina do Trabalho no prazo de 90 (noventa) dias a contar de sua instalação.

4.3.1.2. As empresas novas, integrantes de grupos empresariais que já possuam serviço único poderão ser assistidas pelo referido serviço, após comunicação à DRT.

4.3.2. À Secretaria de Segurança e Medicina do Trabalho fica reservado o direito de controlar a execução do programa e aferir a sua eficácia.

4.3.3. O serviço único de engenharia e medicina deverá possuir os profissionais especializados previstos no Quadro II anexo, sendo permitido aos demais 
engenheiros e médicos exercerem engenharia de segurança e medicina do trabalho, desde que habilitados e registrados conforme estabelece a NR-27.

4.3.4. 0 dimensionamento do serviço único de engenharia e medicina deverá obedecer ao disposto no Quadro II desta NR, no tocante aos profissionais especializados.

4.4. Os Serviços Especializados em Engenharia de Segurança e em Medicina do Trabalho deverão ser integrados por Médico do Trabalho, Engenheiro de Segurança do Trabalho, Enfermeiro do Trabalho, Técnico de Segurança do Trabalho e Auxiliar de Enfermagem do Trabalho, obedecido o Quadro II anexo.

4.4.1. Para fins desta Norma Regulamentadora, as empresas obrigadas a constituir Serviços Especializados em Engenharia de Segurança e em Medicina do Trabalho, deverão exigir dos profissionais que os integram, comprovação de que satisfazem os seguintes requisitos:

a) Engenheiro de Segurança do Trabalho - engenheiro ou arquiteto portador de certificado de conclusão de curso de especialização em Engenharia de Segurança do Trabalho, em nível de pós-graduação;

b) Médico do Trabalho - médico portador de certificado de conclusão de curso de especialização em Medicina do Trabalho, em nível depôs-graduação, ou portador de certificado de residência médica em área de concentração em saúde do trabalhador ou denominação equivalente, reconhecida pela Comissão Nacional de Residência Médica, do Ministério da Educação, ambos ministrados por universidade ou faculdade que mantenha curso de graduação em medicina.

c) Enfermeiro do Trabalho - enfermeiro portador de certificado de conclusão de curso de especialização em Enfermagem do Trabalho, em nível de pós-graduação, ministrado por universidade ou faculdade que mantenha curso de graduação em enfermagem;

d) Auxiliar de Enfermagem do Trabalho - auxiliar de enfermagem ou técnico de enfermagem portador de certificado de conclusão de curso de qualificação de Auxiliar de Enfermagem do Trabalho, ministrado por instituição especializada reconhecida e autorizada pelo Ministério da Educação;

e) Técnico de Segurança do Trabalho: técnico portador de comprovação de Registro Profissional expedido pelo Ministério do Trabalho.

4.4.1.1. Em relação às Categorias mencionadas nas alíneas a e e, observar-se-á o disposto na Lei $\mathrm{n}^{\circ} 7.410$, de 27 de novembro de 1985.

4.4.2. Os profissionais integrantes dos Serviços Especializados em Engenharia de Segurança e em Medicina do Trabalho deverão ser empregados da empresa, salvo os casos previstos nos itens 4.14 e 4.15 . 
4.5. A empresa que contratar outra(s) para prestar serviços em estabelecimentos enquadrados no Quadro II anexo deverá estender a assistência de seus Serviços Especializados em Engenharia de Segurança e em Medicina do Trabalho aos empregados da(s) contratada(s), sempre que o número de empregados desta(s), exercendo atividade naqueles estabelecimentos não alcançar os limites previstos no Quadro II, devendo, ainda, a contratada cumprir o disposto no subitem 4.2.5.

4.5.1. Quando a empresa contratante e as outras por ela contratadas não se enquadrarem no Quadro li anexo, mas que pelo número total de empregados de ambas, no estabelecimento, atingirem os limites dispostos no referido quadro, deverá ser constituído um Serviço Especializado em Engenharia de Segurança e em Medicina do Trabalho comum, nos moldes do item 4.14 .

4.5.2. Quando a empresa contratada não se enquadrar no Quadro II anexo, mesmo considerando-se o total de empregados nos estabelecimentos, a contratante deve estender aos empregados da contratada a assistência de seus Serviços Especializados em Engenharia de Segurança e em Medicina do Trabalho, sejam estes centralizados ou por estabelecimento.

4.6. Os Serviços Especializados em Engenharia de Segurança e em Medicina do Trabalho das empresas que operem em regime sazonal deverão ser dimensionados, tomando-se por base a média aritmética do número de trabalhadores do ano civil anterior e obedecidos os Quadros 1 e II anexos.

4.7. Os Serviços Especializados em Engenharia de Segurança e em Medicina do Trabalho deverão ser chefiados por profissional qualificado, segundo os requisitos especificados no subitem 4.4.1 desta Norma Regulamentadora.

4.8. O técnico de segurança do trabalho e o auxiliar de enfermagem do trabalho deverão dedicar 8 (oito) horas por dia para as atividades dos Serviços Especializados em Engenharia de Segurança e em Medicina do Trabalho, de acordo com o estabelecido no Quadro II anexo.

4.9. O engenheiro de segurança do trabalho, o médico do trabalho e o enfermeiro do trabalho deverão dedicar, no mínimo, 3 (três) horas (tempo parcial) ou 6 horas (tempo integral) por dia para as atividades dos Serviços Especializados em Engenharia de Segurança e em Medicina do Trabalho, de acordo com o estabelecido no Quadro II anexo, respeitada a legislação pertinente em vigor.

4.10. Ao profissional especializado em Segurança e em Medicina do Trabalho é vedado o exercício de outras atividades na empresa, durante o horário de sua atuação nos Serviços Especializados em Engenharia de Segurança e em Medicina do Trabalho.

4.11. Ficará por conta exclusiva do empregador todo o ônus decorrente da instalação e manutenção dos Serviços Especializados em Engenharia de Segurança e em Medicina do Trabalho. 
4.12. Compete aos profissionais integrantes dos Serviços Especializados em Engenharia de Segurança e em Medicina do Trabalho:

a) aplicar os conhecimentos de Engenharia de Segurança e de Medicina do Trabalho ao ambiente de trabalho e a todos os seus componentes, inclusive máquinas e equipamentos, de modo a reduzir até eliminar os riscos ali existentes à saúde do trabalhador;

b) determinar, quando esgotados todos os meios conhecidos para a eliminação do risco e este persistir, mesmo reduzido, a utilização, pelo trabalhador, de equipamentos de proteção individual (EPI), de acordo com o que determina a NR-6, desde que a concentração, a intensidade ou característica do agente assim o exija;

c) colaborar, quando solicitado, nos projetos e na implantação de novas instalações físicas e tecnológicas da empresa, exercendo a competência disposta na alínea "a",

d) responsabilizar-se, tecnicamente, pela orientação quanto ao cumprimento do disposto nas NR aplicáveis às atividades executadas pela empresa e/ou seus estabelecimentos;

e) manter permanente relacionamento com a CIPA, valendo-se ao máximo de suas observações, além de apoiá-la, treiná-la e atendê-la, conforme dispõe a NR-5;

f) promover a realização de atividades de conscientização, educação e orientação dos trabalhadores para a prevenção de acidentes do trabalho e doenças ocupacionais, tanto através de campanhas, quanto de programas de duração permanente;

g) esclarecer e conscientizar os empregados sobre acidentes do trabalho e doenças ocupacionais, estimulando-os em favor da prevenção;

h) analisar e registrar em documento(s) específico(s) todos os acidentes ocorridos na empresa ou estabelecimento, com ou sem vítima, e todos os casos de doença ocupacional, descrevendo a história e as características do acidente e/ou da doença ocupacional, os fatores ambientais, as características do agente e as condições do(s) indivíduo(s) portador(es) de doença ocupacional ou acidentado(s);

i) registrar mensalmente os dados atualizados de acidentes do trabalho, doenças ocupacionais e agentes de insalubridade preenchendo, no mínimo, os quesitos descritos nos modelos de mapas constantes nos Quadros III, IV, V e VI, devendo a empresa encaminhar um mapa contendo avaliação anual dos mesmos dados à Secretaria de Segurança e Medicina do Trabalho até o dia 31 de janeiro, através do órgão regional do MTb;

j) manter os registros de que tratam as alíneas 'h e i' na sede dos Serviços Especializados em Engenharia de Segurança e em Medicina do Trabalho ou facilmente alcançáveis a partir da mesma, sendo de livre escolha da empresa o método de arquivamento e recuperação desde que sejam asseguradas condições de acesso aos registros e entendimento de seu conteúdo, devendo ser guardados somente os mapas anuais dos dados correspondentes às alíneas " $h$ " e "i" por um período não inferior a 5 (cinco) anos;

1) as atividades dos profissionais integrantes dos Serviços Especializados em Engenharia de Segurança e em Medicina do Trabalho são essencialmente prevencionistas, embora não seja vedado o atendimento de emergência, quando se torna necessário. Entretanto, a elaboração de planos de controle de efeitos de catástrofes, de disponibilidade de meios que visem ao combate a incêndios e ao 
salvamento e de imediata atenção à vítima deste ou de qualquer outro tipo de acidente estão incluídos em suas atividades.

4.13. Os Serviços Especializados em Engenharia de Segurança e em Medicina do Trabalho deverão manter entrosamento permanente com a CIPA, dela valendo-se como agente multiplicador, e deverão estudar suas observações e solicitações, propondo soluções corretivas e preventivas, conforme o disposto no subitem 5.14.1. da NR-5.

4.14. As empresas cujos estabelecimentos não se enquadrem no Quadro II, anexo a esta NR, poderão dar assistência na área de segurança e medicina do trabalho a seus empregados através de Serviços Especializados em Engenharia de Segurança e em Medicina do Trabalho comuns organizados pelo sindicato ou associação da categoria econômica correspondente ou pelas próprias empresas interessadas.

4.14.1. A manutenção desses Serviços Especializados em Engenharia de Segurança e em Medicina do Trabalho deverá ser feita pelas empresas usuárias que participarão das despesas em proporção ao número de empregados de cada uma.

4.14.2. Os Serviços Especializados em Engenharia de Segurança e em Medicina do Trabalho previstos no tem 4.14. deverão ser dimensionados em função do somatório dos empregados das empresas participantes, obedecendo ao disposto nos Quadros 1 e II no subitem 4.12.12 desta NR.

4.15. As empresas referidas no item 4.14. poderão optar pelos Serviços Especializados em Engenharia de Segurança e em Medicina do Trabalho de instituição oficial ou instituição privada de utilidade pública, cabendo às empresas o custeio das despesas, na forma prevista no subitem 4.14.1.

4.16. As empresas cujos Serviços Especializados em Engenharia de Segurança e em Medicina do Trabalho não possuam médico e/ou engenheiro de segurança do trabalho, de acordo com o Quadro II desta NR, poderão se utilizar dos serviços destes profissionais existentes nos Serviços Especializados em Engenharia de Segurança e em Medicina do Trabalho mencionados no item 4.14 e subitem 4.14.1 ou no subitem 4.15 para atendimento do disposto nas Normas Regulamentadoras.

4.16.1. O ônus decorrente dessa utilização caberá à empresa solicitante.

4.17. Os Serviços Especializados em Engenharia de Segurança e em Medicina do Trabalho de que trata esta NR deverão ser registrados no órgão regional do MTb.

4.17.1. O registro referido no item 4.17 deverá ser requerido ao órgão regional do MTb e o requerimento deverá conter os seguintes dados:

a) nome dos profissionais integrantes dos Serviços Especializados em Engenharia de Segurança e em Medicina do Trabalho;

b) número de registro dos profissionais na Secretaria de Segurança e Medicina do Trabalho, do MTb; 
c) número de empregados da requerente e grau de risco das atividades, por estabelecimento;

d) especificação dos turnos de trabalho por estabelecimento;

e) horário de trabalho dos profissionais dos Serviços Especializados em Engenharia de Segurança e em Medicina do Trabalho.

4.18. Os Serviços Especializados em Engenharia de Segurança e em Medicina do Trabalho já constituídos deverão ser redimensionados nos termos desta NR e a empresa terá 90 (noventa) dias de prazo, a partir da publicação desta Norma, para efetuar o redimensionamento e o registro referido no item 4.17 .

4.19. A empresa é responsável pelo cumprimento da NR, devendo assegurar, como um dos meios para concretizar tal responsabilidade, o exercício profissional dos componentes dos Serviços Especializados em Engenharia de Segurança e em Medicina do Trabalho. O impedimento do referido exercício profissional, mesmo que parcial, e o desvirtuamento ou desvio de funções constituem, em conjunto ou separadamente, infrações classificadas no grau 14, se devidamente comprovadas, para os fins de aplicação das penalidades previstas na NR-28.

4.20. Quando se tratar de empreiteiras ou empresas prestadoras de serviços, considerase estabelecimento, para fins de aplicação desta NR, o local em que os seus empregados estiverem exercendo suas atividades.

SECURANÇA E MEDICINA DO TRABALHO

QUADRO II

DIMENSIONAMENTO DOS SESMT

\begin{tabular}{|c|c|c|c|c|c|c|c|c|c|}
\hline $\begin{array}{l}\text { GRAU } \\
\text { DE } \\
\text { FuSCO }\end{array}$ & Nicos & $\underset{160}{A 0}$ & $\begin{array}{c}101 \\
\text { A } \\
250\end{array}$ & $\begin{array}{c}251 \\
\text { A } \\
000\end{array}$ & $\begin{array}{c}501 \\
\text { A } \\
1.000\end{array}$ & $\underset{2.009}{1.009}$ & $\begin{array}{c}2.001 \\
\text { A } \\
2.500\end{array}$ & $\begin{array}{c}1.501 \\
\text { A } \\
5.060\end{array}$ & 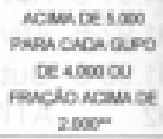 \\
\hline 1 & 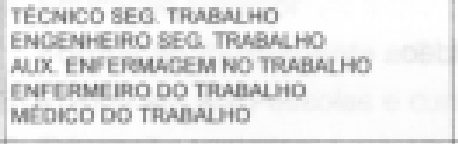 & & & & 1 & 1 & $\begin{array}{c}1 \\
1 \\
1 \\
1\end{array}$ & $\begin{array}{l}2 \\
1 \\
1 \\
1 \\
1 \\
1\end{array}$ & $\begin{array}{l}1 \\
1 \\
1 \\
1\end{array}$ \\
\hline 2 & 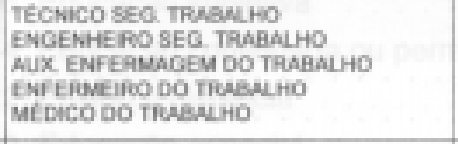 & & & & 1 & $\begin{array}{l}1 \\
1 * \\
1 \\
1 *\end{array}$ & $\begin{array}{l}2 \\
1 \\
1 \\
1 \\
1\end{array}$ & $\begin{array}{l}5 \\
1 \\
1 \\
1 \\
1 \\
1\end{array}$ & $\begin{array}{l}1 \\
1 \\
1 \\
1 \\
1\end{array}$ \\
\hline 3 & $\begin{array}{l}\text { TECNACO SEQ TRMENLHO } \\
\text { ENGENHERO SEQ TRABALHO } \\
\text { ALX ENFEAMACEM NO TRABALHO } \\
\text { ENF EDONEIPO DO TRABALHO } \\
\text { ME DICO DO TRABALHO }\end{array}$ & & 1 & 2 & $\begin{array}{l}3 \\
1 *\end{array}$ & $\begin{array}{l}4 \\
1 \\
1 \\
1 \\
1\end{array}$ & $\begin{array}{l}6 \\
1 \\
2 \\
1\end{array}$ & $\begin{array}{l}3 \\
2 \\
1 \\
1 \\
2\end{array}$ & $\begin{array}{l}3 \\
1 \\
1 \\
1\end{array}$ \\
\hline 4 & 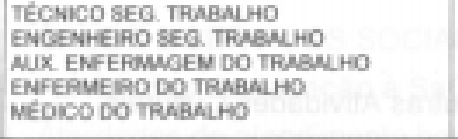 & 1 & $\begin{array}{l}2 \\
1 *\end{array}$ & $\begin{array}{l}3 \\
1^{4}\end{array}$ & $\begin{array}{l}4 \\
1 \\
1\end{array}$ & $\begin{array}{l}5 \\
1 \\
1\end{array}$ & $\begin{array}{l}3 \\
2\end{array}$ & $\begin{array}{c}10 \\
3 \\
1 \\
1 \\
3\end{array}$ & $\begin{array}{l}3 \\
1 \\
1 \\
1\end{array}$ \\
\hline (7)- & \multicolumn{3}{|c|}{ 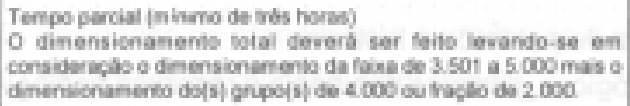 } & \multicolumn{6}{|c|}{ 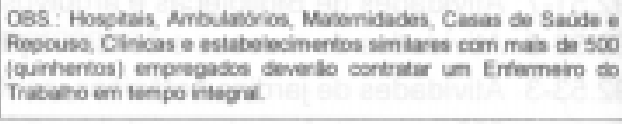 } \\
\hline
\end{tabular}




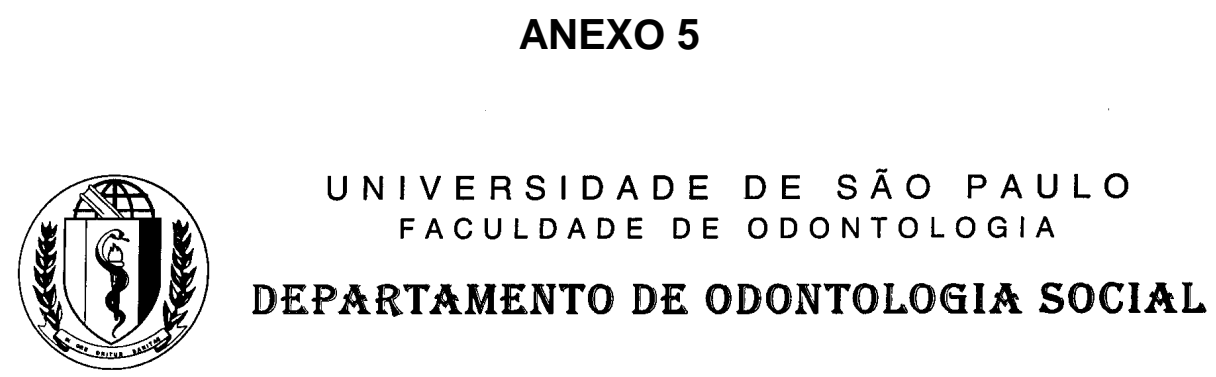

Este questionário faz parte do material da Dissertação de Mestrado, cujo tema é: Estudo exploratório a respeito da Odontologia do Trabalho nas empresas de grande porte do município de São Paulo, que está sendo realizado junto ao Departamento de Odontologia Social da Faculdade de Odontologia da Universidade de São Paulo (FOUSP).

Todos os dados deste questionário serão mantidos sob sigilo e faremos a devolução dos resultados para as empresas que colaborarem no presente trabalho.

Solicitamos à área de Recursos Humanos que encaminhe os questionários para o Diretor de $\mathrm{RH}$, o Médico do Trabalho, o Engenheiro de Segurança do Trabalho e, se houver, para o Cirurgião-Dentista.

Agradecemos de antemão a sua colaboração e a gentileza de remetê-los preenchidos no envelope anexo, pelo correio, até o dia 15/12/98.

Muito Obrigado.

\section{Edward Toshiyuki Midorikawa}

Cirurgião-Dentista, Especialista em Administração Hospitalar e de Sistemas de Saúde pela FGV e

Mestrando em Deontologia e Odontologia Legal pela Fac. de Odontologia da USP

Obs: para maiores esclarecimentos entrar em contato com Edward no telefone(011) 280-9315,

(011) 818-7891, ou pelo E-mail: p-edward@siso.fo.usp.br 
UNIVERSIDADE DE SÃO PAULO

FACULDADE DE ODONTOLOGIA

\section{DEPARTAMENTO DE ODONTOLOGIA SOCIAL}

Este questionário faz parte do material da Dissertação de Mestrado, cujo tema é: Estudo exploratório a respeito da Odontologia do Trabalho nas empresas de grande porte do município de São Paulo, que está sendo realizado junto ao Departamento de Odontologia Social da Faculdade de Odontologia da Universidade de São Paulo (FOUSP). Todos os dados deste questionário serão mantidos sob sigilo e faremos a devolução dos resultados para as empresas que colaborarem no presente trabalho. Agradecemos de antemão a sua colaboração e a gentileza de devolvê-lo preenchido ao setor de $\mathrm{RH}$, o mais breve possível, para que possa ser remetido até o dia 15/12/98.

Obrigado.

\section{Edward Toshiyuki Midorikawa}

Cirurgião-Dentista, Especialista em Administração Hospitalar e de Sistemas de Saúde pela FGV e Mestrando em Deontologia e Odontologia Legal pela Fac. de Odontologia da USP

Orientador: Prof. Dr. Marco Segre

Prof. Titular do Depto de Medicina Legal, Ética Médica, Medicina Social e do Trabalho da Fac. de Medicina da USP

IDENTIFICAÇÃo

Empresa: no de funcionários:

Nome:

Cargo: Tel:

Endereço: CEP:

Bairro: Cidade: Estado: 


\section{QUESTIONÁRIO}

1) A empresa possui um Serviço Especializado em Segurança e Medicina do Trabalho (SESMT)?
( ) Sim
( ) Não

2) Qual é a sua composição?

( ) Médico do Trabalho - no:

( ) Enfermeira do Trabalho - $n$ :

( ) Auxiliar de Enfermagem do Trabalho - $\mathrm{n}$ :

( ) Engenheiro de Segurança do Trabalho - $n^{\circ}$ :

( ) Técnico de Segurança do Trabalho - no:

( ) outros: $-\mathrm{n}^{0}$

3) Para o senhor(a) a Saúde Bucal:

( ) é importante para o bom desempenho dos funcionários mas não é de responsabilidade da empresa.

( ) não faz diferença para o bom desempenho dos funcionários.

( ) é importante para o bom desempenho dos funcionários e a empresa deve facilitar o acesso ao tratamento odontológico.

4) A empresa possui um serviço odontológico?

( ) Sim ( ) Não

5) Pertence a quem?

( ) à empresa

( ) Terceirizada. Qual?

( ) Ambos. Qual?

6) Qual(ais) são a(s) função(ões) exercida(s) por este(s) serviço(s)?

7) A respeito da Saúde Bucal dos funcionários o senhor(a) acha que está:
( ) boa
( ) ruim
( ) não sabe

8) Para o senhor(a) como pode ser definido Odontologia do Trabalho?

9) Quais as funções que este profissional (Cirurgião-Dentista do Trabalho) poderia, na sua opinião, desempenhar dentro da equipe de saúde ocupacional ou do trabalhador?

10) Observações e comentários: 


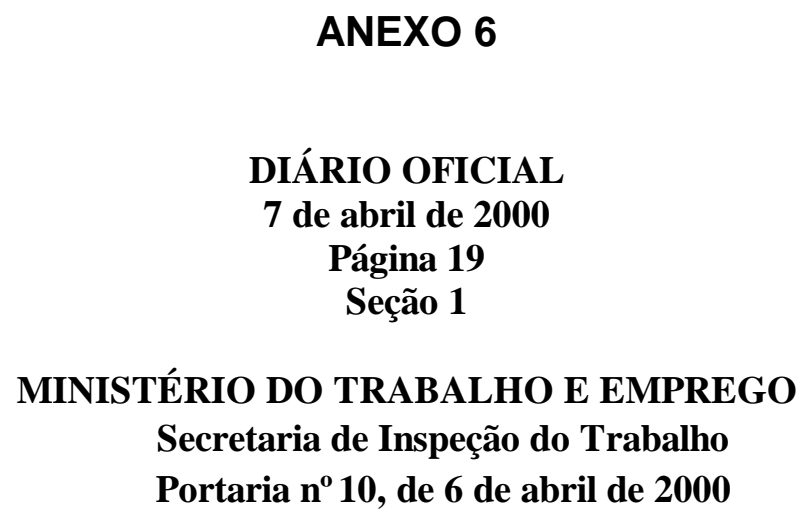

A SECRETÁRIA DE INSPEÇÃo DO TRABALHO e o DIRETOR DE SEGURANÇA E SAÚDE NO TRABALHO, no uso das atribuições que lhes confere o artigo IV da Portaria n ${ }^{\circ}$ 393, de 9 de abril de 1996, resolvem:

Art. $1^{\circ}$ - Divulgar para consulta pública a proposta de alteração da NR 4 -Serviço Especializado em Engenharia de Segurança e em Medicina do Trabalho - SESMT, especialmente quanto ao Quadro I - Gradação de Risco por Classificação Nacional de Atividades Econômica / CNAE, como a seguir demonstrado:

\section{NR 4- SISTEMA INTEGRADO DE PREVENÇÃO DE RISCOS DO TRABALHO}

4.1 O Sistema Integrado de Prevenção de Riscos do Trabalho - SPRT consiste no conjunto permanente de ações, medidas e programas, previstos em normas e regulamentos, além daqueles desenvolvidos por livre iniciativa da empresa, tendo como objetivo a prevenção de acidentes e doenças, de modo a tomar compatível permanentemente o trabalho com a preservação da vida, a promoção da saúde do trabalhador e do meio ambiente de trabalho;

4.2 É responsabilidade do empregador implantar o SPRT, objetivando garantir, permanentemente, um nível mais eficaz de segurança e saúde a todos os trabalhadores, observando como princípios básicos:

a) a integração da atividade preventiva ao processo produtivo, abrangendo todos os aspectos relacionados ao trabalho;

b)o planejamento das ações de prevenção, através da implementação dos programas de gestão da segurança e saúde do trabalhador; 
c)a participação dos trabalhadores no planejamento, execução e avaliação das medidas adotadas pela empresa;

d)o emprego de técnicas atualizadas de prevenção;

4.3 As ações de prevenção de acidentes e doenças do trabalho pressupõem:

a)a adaptação do trabalho ao homem, especialmente, na concepção dos postos de trabalho, escolha de equipamentos e métodos de produção, incluindo a atenuação do trabalho monótono e repetitivo;

b)o conhecimento das condições de cada atividade e posto de trabalho em relação a organização, ao meio ambiente de trabalho, às relações sociais e às inovações tecnológicas;

c) a avaliação dos riscos para a segurança e saúde dos trabalhadores em todas as fases do processo de produção;

d)o combate aos riscos na sua origem, priorizando as medidas de proteção coletiva, incluindo aquelas derivadas da substituição de matérias-primas ou insumos que exponham a saúde dos trabalhadores;

e) a adoção de medidas destinadas a assegurar o adequado controle à saúde dos trabalhadores;

f) a análise de acidentes e doenças do trabalho, de forma participativa, mantendo adequados registros de informação;

g)o acompanhamento das atividades de trabalho que tenham causado acidentes ou doenças, avaliando, na normalidade, os determinantes desses eventos;

h)o desenvolvimento de atividades educativas em prevenção para todos os trabalhadores, inclusive, para os ocupantes de cargos de direção e chefia, com conteúdo específico para a gestão do SPRT.

i) a implementação dos programas de prevenção previstos nas demais NR.

\subsection{O empregador deverá:}

a) garantir que os meios e recursos da empresa ou do estabelecimento sejam suficientes para observar os objetivos e princípios do SPRT;

b) recorrer a profissionais especializados em segurança e saúde no trabalho de acordo com o previsto nas NR; 
c) quando delegar atribuições e responsabilidades, garantir condições para que os vários níveis hierárquicos e setores da empresa incorporem a obrigação da prevenção de riscos, em quaisquer atividades que realizem e nas decisões que adotem.

4.5 Os trabalhadores devem de acordo com sua formação e instruções fornecidas pelo empregador:

a) participar e cooperar na efetivação dos princípios, objetivos e ações que compõem o SPRT;

b) utilizar corretamente as máquinas e equipamentos, bem como os equipamentos de proteção coletiva e individual;

c) cuidar dos dispositivos de segurança, não desligando, mudando ou deslocando arbitrariamente os mesmos;

d) comunicar imediatamente à sua chefia e aos trabalhadores que desempenham funções específicas em matéria de segurança e saúde do trabalhador, as situações sobre as quais existam suspeitas de risco grave e iminente;

e) zelar pela sua segurança e saúde, bem como pela segurança e saúde de outras pessoas que possam ser afetadas por suas ações;

4.5.1 Os trabalhadores com atribuições no SPRT deverão dispor do tempo adequado para realizar suas funções, não podendo ser prejudicados por sua participação nas atividades de proteção e de prevenção dos riscos profissionais;

4.6 O SPRT deverá ser organizado e desenvolvido nas empresas privadas ou públicas, independente do setor econômico e do número de empregados, contando com a participação, no mínimo, do:

a) designado da CIPA previsto na NR 5, nos estabelecimentos não obrigados a constituir CIPA;

b) Presidente e vice-presidente da CIPA, nos estabelecimentos obrigados a constituir essa Comissão; 


\section{Do Serviço Especializado em Segurança e Saúde no Trabalho - SEST}

4.7 O SEST é um serviço especializado constituído por uma unidade organizada e integrada, composta por profissionais dedicados exclusivamente ao cumprimento de atribuições relacionadas à prevenção de riscos laborais.

4.8 O SEST tem por atribuições o desenvolvimento das ações técnicas necessárias a observação do cumprimento dos princípios e dos objetivos do SPRT, inclusive quanto à observância do disposto nas NR, em especial aquelas referentes aos programas de gestão da segurança e saúde no trabalho.

4.9 As empresas com mais de vinte empregados, observando o disposto nesta NR, deverão contratar ou constituir uma das seguintes modalidades de SEST:

a) Próprio: quando os profissionais especializados mantiverem vínculo empregatício com a empresa;

b) Externo: quando a empresa terceirizar a contratação dos profissionais especializados;

c) Coletivo: quando um segmento empresarial ou econômico terceirizar a contratação dos profissionais especializados.

4.10 O SEST deverá ser composto pelos seguintes profissionais especializados:

I - de nível superior:

a) Engenheiro de Segurança do Trabalho;

b) Médico do Trabalho;

c) Enfermeiro do Trabalho.

II - de nível médio:

a) Técnico de Segurança do Trabalho;

b) Auxiliar de Enfermagem do Trabalho.

4.10.1 Essa composição poderá ser alterada por convenção coletiva, para indicar outros profissionais especializados, que melhor atendam às necessidades de implementação do SPRT. 
4.10.2 Sempre que se fizer necessário o SEST poderá contar com a colaboração de profissionais com formação específica, diversa daquelas dos seus integrantes.

\section{Do SEST Próprio}

4.11 Para fins de SEST Próprio, as empresas, em função de seu código na Classificação Nacional de Atividades Econômicas _CNAE e de parâmetros técnicos, estabelecidos e reavaliados trienalmente pelo Ministério do Trabalho e Emprego através da CTPP, serão enquadradas nos Grupos A, B e C, previstos no Anexo I.

4.11.1 Dos parâmetros técnicos deverão constar obrigatoriamente indicadores de mortalidade, morbidade e de doenças ocupacionais de cada grupo de setores econômicos.

4.12 Será obrigatória a constituição de SEST Próprio para as empresa que se enquadrarem nos dimensionamentos previstos nos Quadros 1 e II da presente NR.

4.13 O dimensionamento do SEST Próprio quanto aos profissionais de nível superior, será feito de acordo com o Grupo e com o número de empregados da empresa, por unidade da federação, observando o Quadro 1 em anexo.

4.14 O dimensionamento do quantitativo dos profissionais de nível médio observará o Grupo e o número de empregados do estabelecimento, de acordo com o Quadro II em anexo.

4.15 A empresa deverá comunicar ao sindicato da categoria profissional predominante o nome, a formação e a jornada de trabalho dos integrantes do SEST Próprio.

\section{Do SEST Externo}


4.16 As empresas com mais de vinte empregados, desobrigadas de constituir SEST Próprio, deverão contratar os serviços de uma empresa especializada em segurança e saúde no trabalho, que será considerado como SEST Externo.

4.17 O SEST Externo, para desenvolver suas ações, deverá obedecer às seguintes condições:

a) exercer exclusivamente atividades de prestação de serviços em segurança e saúde no trabalho;

b) contar com o número mínimo de profissionais estabelecidos em Quadro específico a ser elaborado pelo MTE, devendo os mesmos ser empregados ou sócios do SEST;

c) possuir personalidade jurídica própria.

4.18 Os programas de gestão da segurança e saúde no trabalho nas empresas que utilizem SEST Externo deverão mencionar a razão social, a composição da empresa prestadora de serviços, endereço e CNPJ ou CGC.

4.19 O SEST Externo, com mais de um ano de funcionamento, deverá manter à disposição da fiscalização do trabalho uma memória anual de suas atividades constando, no mínimo, as empresas onde atuou e quais foram os serviços prestados no período.

4.20 O SEST Externo deverá ser credenciado no órgão regional do Ministério do Trabalho e Emprego devendo para tanto apresentar:

a) os programas que o compõe;

b) as empresas atendidas;

c) profissionais e recursos técnicos disponíveis;

d) acordo ou convenção coletiva, quando for o caso.

4.20.1 O SEST Externo poderá ser descredenciado pelo MTE sempre que os serviços desobedecerem os critérios estabelecidos nesta NR. 
4.21 As empresas que contratarem SEST Externo devem observar as seguintes condições:

a) comunicar ao sindicato da categoria profissional predominante a prestadora de serviços que pretende contratar;

b) manter à disposição da fiscalização, em todos os seus estabelecimentos, documento atualizado comprobatório do SEST Externo.

4.22 Também poderão recorrer aos serviços de um SEST Externo:

a) empresas não obrigadas a constituir nenhuma das modalidades deste Serviço;

b) empresas obrigadas a constituir SEST Próprio, exclusivamente para complementação dos serviços.

\section{Do SEST Coletivo}

4.23 As empresas obrigadas a constituir SEST Próprio ou Externo poderão optar pelo SEST Coletivo quando se configurar uma das seguintes situações:

a) várias empresas instaladas em um mesmo estabelecimento, desde que ouvidos os sindicatos das categorias profissionais predominantes;

b) empresas de um mesmo setor produtivo, estabelecidas em um mesmo mumcípio ou estado da federação, desde que estabelecido em convenção coletiva de trabalho;

c) empresas situadas em pólos ou centros industriais, desde que estabelecido em acordos coletivos de trabalho;

d) várias empresas sob controle acionário de um mesmo grupo econômico, desde que ouvidos os sindicatos das categorias profissionais.

4.24 O SEST Coletivo deverá ser constituído formalmente pelas empresas participantes, devendo suas atividades restringir-se às mesmas.

4.25 O SEST Coletivo deverá ser credenciado no órgão regional do Ministério do Trabalho e Emprego devendo para tanto apresentar:

a) os programas que o compõe;

b) as empresas atendidas;

c) profissionais e recursos técnicos disponíveis; 
d) acordo ou convenção coletiva, quando for o caso.

4.25.1 O SEST Coletivo poderá ser descredenciado pelo MTE sempre que os serviços desobedecerem os critérios estabelecidos nesta NR.

4.26 O SEST Coletivo deverá manter à disposição da fiscalização do trabalho uma memória anual de suas atividades constando, no mínimo, as empresas onde atuou e quais foram os serviços prestados no período.

4.27 O dimensionamento do SEST Coletivo deverá obedecer o estabelecido em Quadro específico a ser elaborado pelo MTE.

4.28 Responderão solidariamente pelas responsabilidades do SEST Coletivo todas as empresas que utilizem de seus serviços.

4.29 O SEST Coletivo deverá desenvolver suas atividades em consonância com os princípios básicos do SPRT de cada empresa.

4.30 As Unidades Descentralizadas do MTE deverão constituir Comissões Tripartites de avaliação e acompanhamento dos SEST nas suas respectivas regiões.

Art. 20 - Fixar prazo de 90 dias, após a publicação deste ato, para o recebimento de sugestões às propostas de alterações da presente portaria, que deverão ser encaminhadas para:

MJNSTÉRIO DO TRABALHO E EMPREGO

Departamento de Segurança e Saúde no Trabalho - Esplanada dos Ministérios, Bloco F, Edifício Anexo, $1^{\circ}$ andar, Ala "B” - CEP 70059-900 - Brasflia - DF

Art. $3^{\circ}$ - Esta portaria entre em vigor na data de sua publicação

Vera Olímpia Gonçalves

Secretária de Inspeção do Trabalho

Juarez Correia Barros Júnior

Diretor de Segurança e Saúde no Trabalho

(Of. El. no 3/2000) 
Quadro 1

Dimensionamento, por emprese, des profissionais de nivel sepperior

\begin{tabular}{|c|c|c|c|c|c|}
\hline $\begin{array}{l}\text { Falka } \\
\text { Grupo }\end{array}$ & $\begin{array}{c}501 \\
a \\
1000\end{array}$ & $\begin{array}{l}1.001 \\
2060\end{array}$ & $\begin{array}{l}2.001 \\
3.500\end{array}$ & $\begin{array}{c}3.501 \\
5.000\end{array}$ & $\begin{array}{c}\text { Pars cada grupe de } \\
\text { 4.000 ou frachầ aclma de } \\
5.000\end{array}$ \\
\hline$A$ & & $\begin{array}{l}1 \text { Médico } \\
1 \text { Eng. }\end{array}$ & $\begin{array}{l}1 \text { Medico } \\
\text { I Fing. }\end{array}$ & $\begin{array}{l}2 \text { Medicos } \\
2 \text { Enz. }\end{array}$ & $\begin{array}{l}1 \text { Madico } \\
1 \text { Fing. }\end{array}$ \\
\hline B & $\begin{array}{l}1 \text { Medice } \\
\text { I Eag. }\end{array}$ & $\begin{array}{l}1 \text { Medico } \\
1 \text { Eng. }\end{array}$ & $\begin{array}{l}1 \text { Mético } \\
1 \text { Eng. }\end{array}$ & $\begin{array}{l}2 \text { Medicus } \\
2 \text { Eag. } \\
1 \text { Faf. }\end{array}$ & $\begin{array}{ll}1 & \text { Mädico } \\
1 & \text { Eag. } \\
1 & \text { Enf. } \\
\end{array}$ \\
\hline $\mathrm{C}$ & $\begin{array}{l}1 \text { Medico } \\
\text { I Ene. }\end{array}$ & $\begin{array}{l}1 \text { Medies } \\
\text { I Eng. }\end{array}$ & $\begin{array}{l}1 \text { Medico } \\
1 \text { Eac }\end{array}$ & $\begin{array}{l}2 \text { Medicos } \\
2 \text { Eac. } \\
1 \text { Enf. }\end{array}$ & $\begin{array}{l}1 \text { Módico } \\
1 \text { Eng } \\
1 \text { Enf. } \\
\end{array}$ \\
\hline
\end{tabular}

Qvadro II

Dimensionomento, por estabelecimento, des profissionais de nivel midio

\begin{tabular}{|c|c|c|c|c|c|c|c|}
\hline $\begin{array}{c}\text { Faisa } \\
\text { Grup } \\
a\end{array}$ & $\begin{array}{c}101 \\
a \\
250\end{array}$ & $\begin{array}{c}251 \\
a \\
500\end{array}$ & $\begin{array}{c}501 \\
a \\
1000\end{array}$ & $\begin{array}{c}1.001 \\
2000 \\
2000\end{array}$ & $\begin{array}{c}2.051 \\
3.500\end{array}$ & $\begin{array}{c}3.501 \\
5.0000\end{array}$ & $\begin{array}{c}\text { Para cada } \\
\text { sropo de } \\
4.000 \text { ou } \\
\text { fraclio aciane } \\
\text { de } 5.000\end{array}$ \\
\hline$A$ & & & I Ténico & $\begin{array}{l}1 \text { Tocrico } \\
1 \text { Ausiliuf } \\
\end{array}$ & $\begin{array}{l}2 \text { Ttenicos } \\
1 \text { Anxiliar }\end{array}$ & \begin{tabular}{|l}
4 Tenisos \\
1 Amxiliar \\
\end{tabular} & $\begin{array}{l}1 \text { Tosrices } \\
1 \text { Ausiliat }\end{array}$ \\
\hline B & & 1 Tócnices & 2 Tecnices & $\begin{array}{l}3 \text { Téricos } \\
1 \text { Ausiliar }\end{array}$ & $\begin{array}{l}4 \text { TEcnioes } \\
1 \text { Auxilixy }\end{array}$ & \begin{tabular}{|l|}
6 Tecriece \\
2 Aux illaves \\
\end{tabular} & $\begin{array}{l}2 \text { Teenicos } \\
1 \text { Ausilier } \\
\end{array}$ \\
\hline C & 1 Técnice & 2 Tbericos & $\begin{array}{l}3 \text { Tenenicos } \\
1 \text { Ausilier }\end{array}$ & $\begin{array}{l}4 \text { TEcaicos } \\
1 \text { Aexiliar }\end{array}$ & $\begin{array}{l}6 \text { Tderioses } \\
2 \text { auxilianes }\end{array}$ & $\begin{array}{l}6 \text { Técnicos } \\
2 \text { ausilines }\end{array}$ & $\begin{array}{l}3 \text { TEeaticas } \\
1 \text { Ausiliar }\end{array}$ \\
\hline
\end{tabular}


ANEXO 7

FICHA DE AVALIAÇĀO DA SAÚDE BUCAL - OMS (1997)

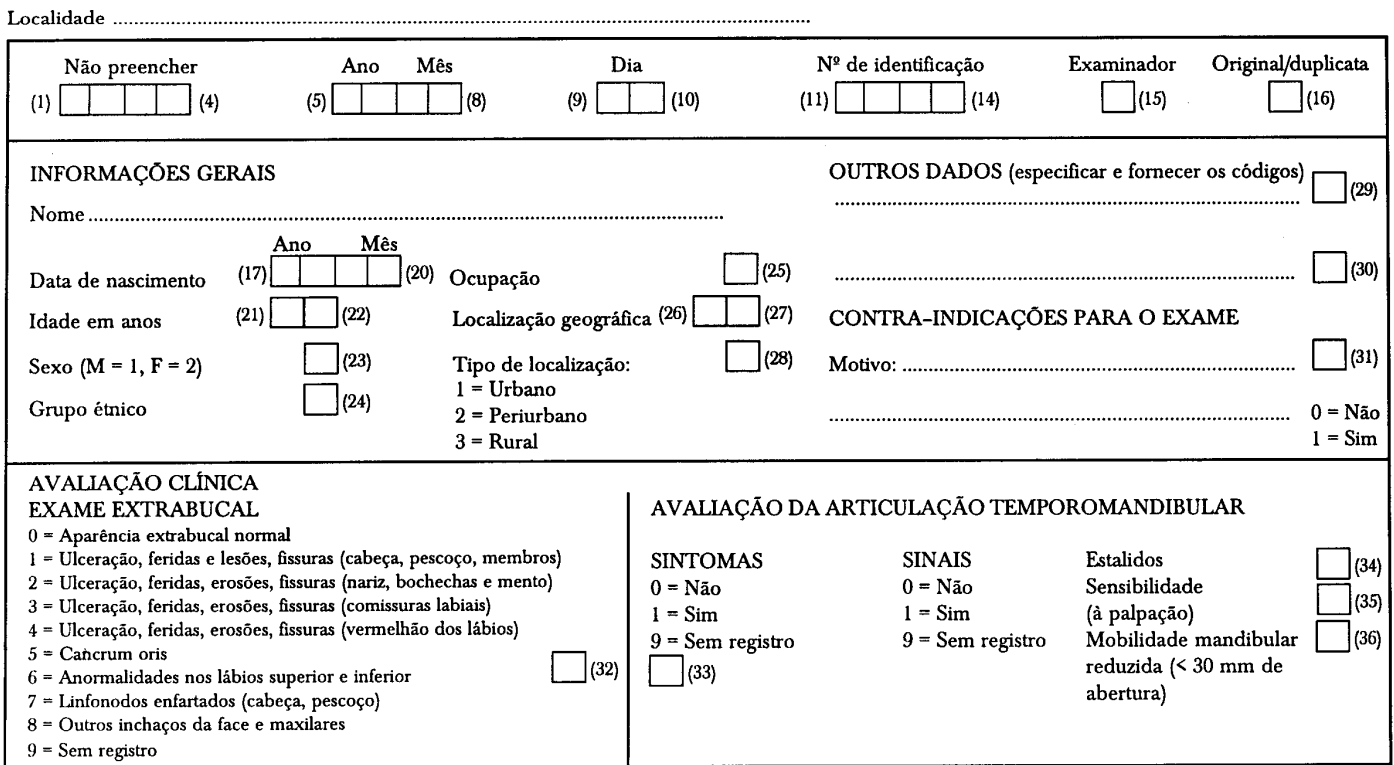

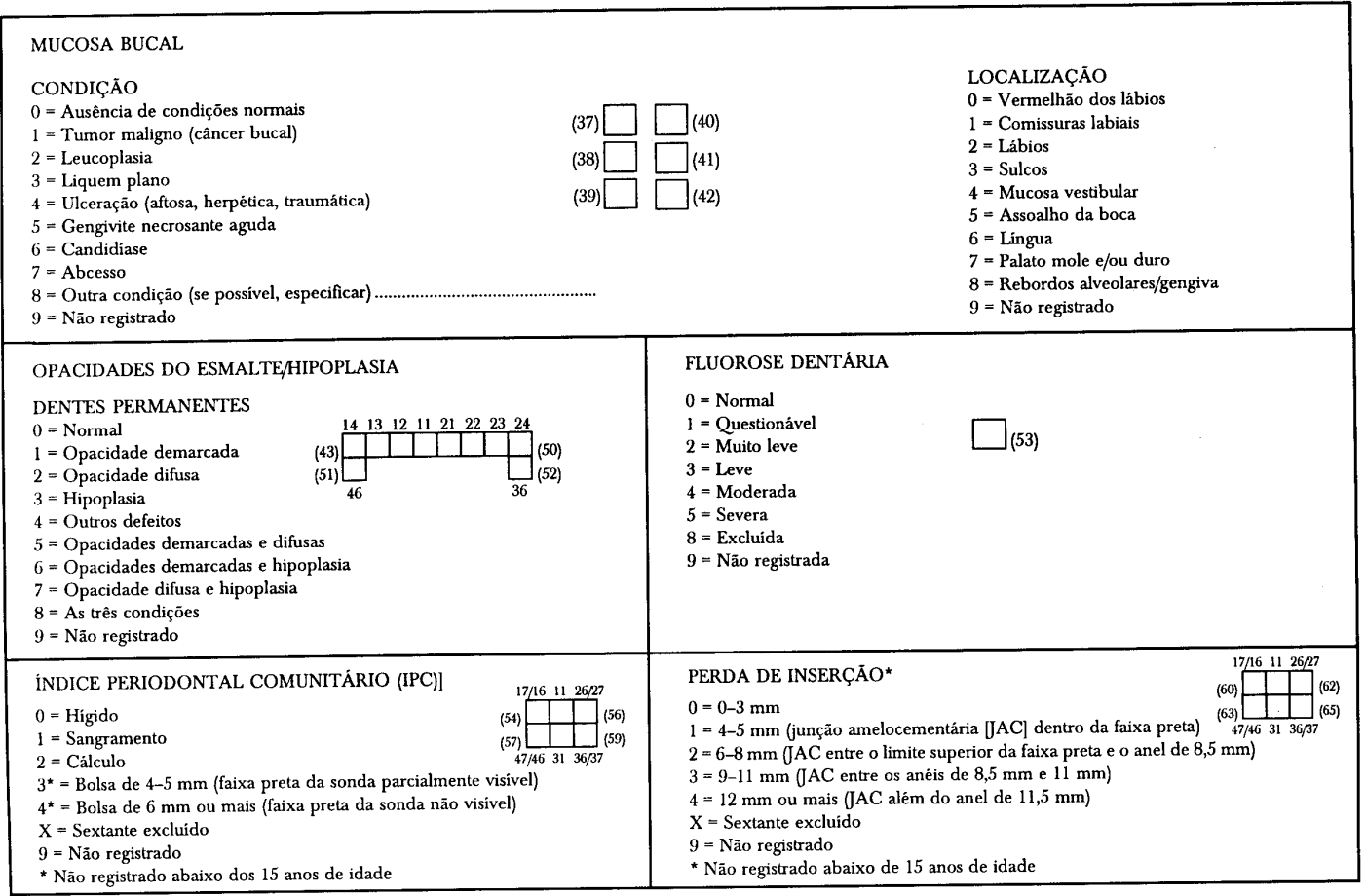




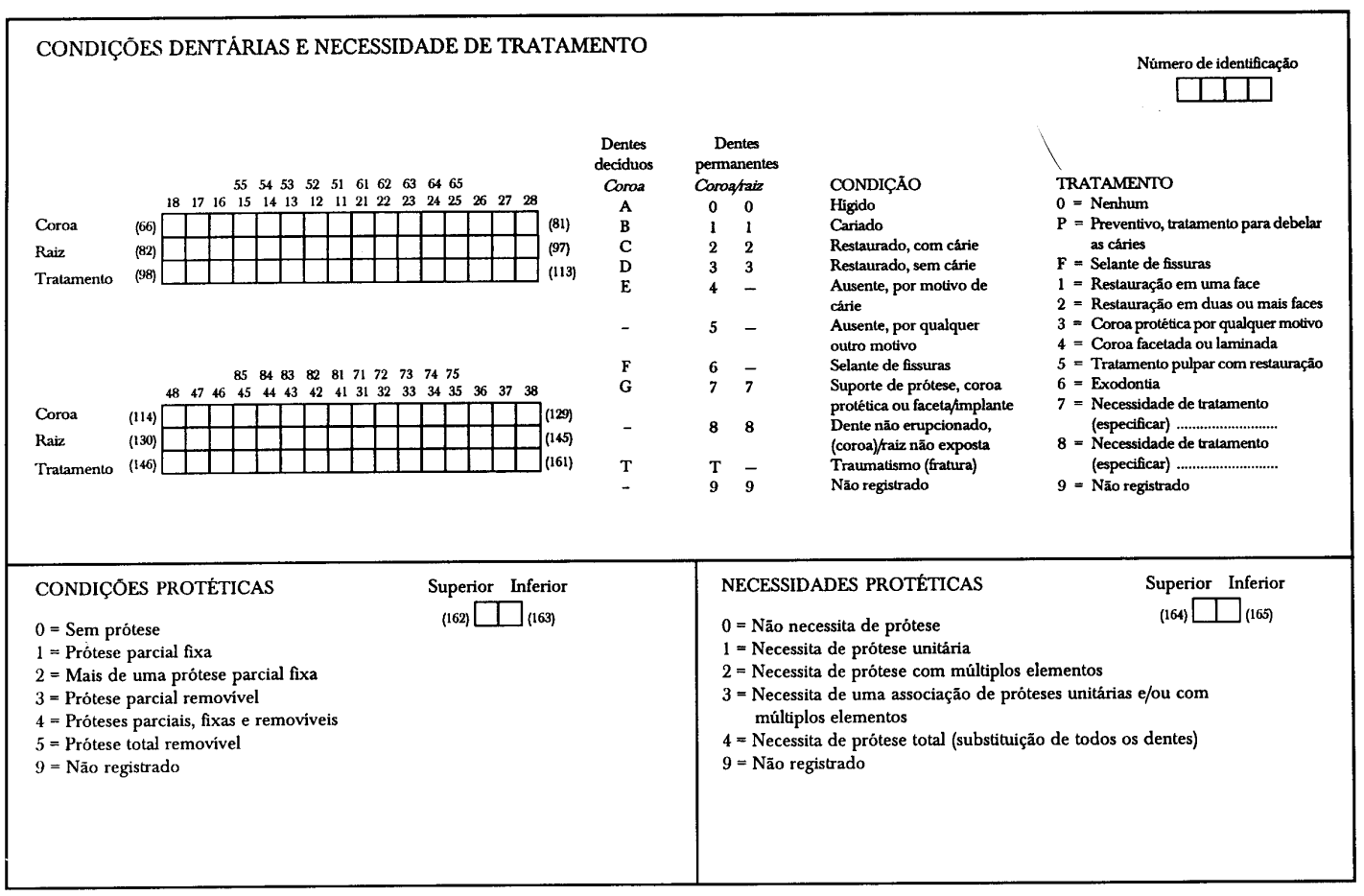

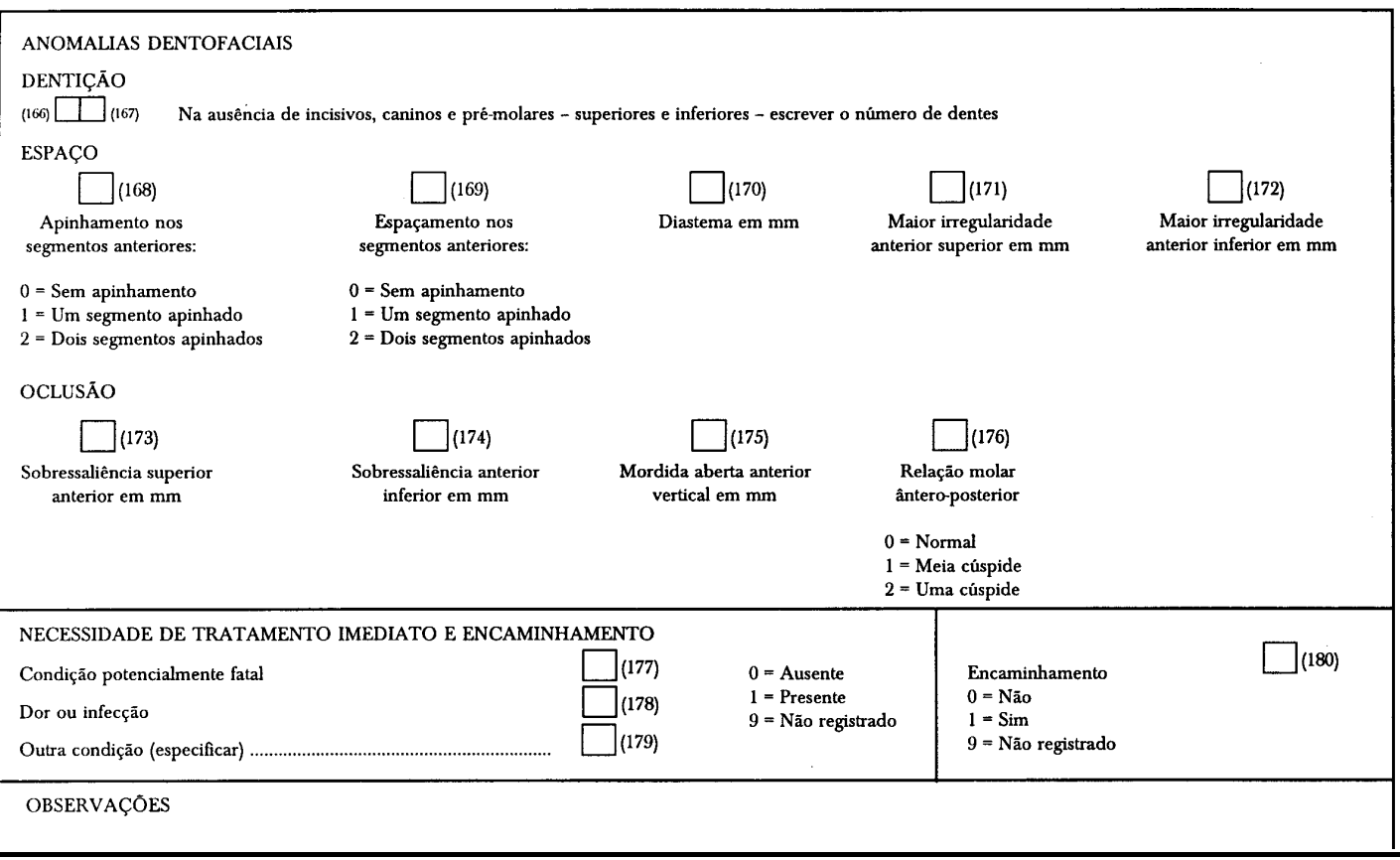




\section{ANEXO 8 \\ Sugestão de um Prontuário em Odontologia em Saúde do Trabalhador}

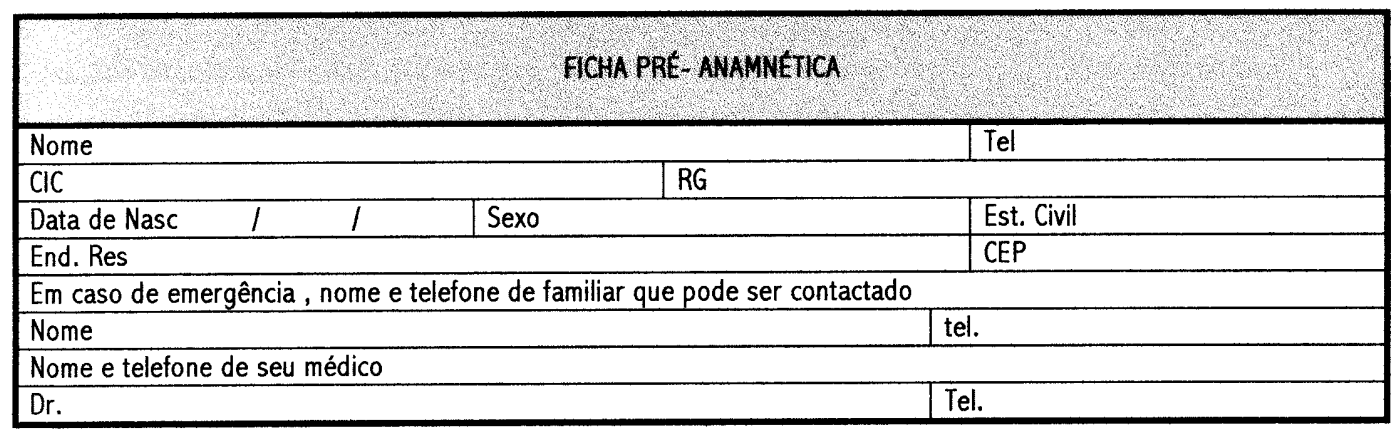

0 presente questionário tem a finalidade de ajudar o seu dentista a conhecer os aspectos de sua saúde geral que podem influir no seu tratamento ou na medicação a ser receitada. É CONFIDENCIAL e deve ser entregue PESSOALMENTE AO CIRURGIÃO-DENTISTA DO TRABALHO.

\section{Questionário de Anamnese}

Responda apenas SIM ou NÃO às perguntas abaixo

01. No momento está em tratamento médico?

02. Está tomando alguma medicação no momento?

03. Tem ou teve alguma doença como hepatite ou siffilis ou outra?

04. Você é hemofilico?

05 . As vezes sente o coraçăo bater muito rapidamente?

06 . Sofre de alguma doença do coração?

07 . Sente falta de ar com frequência?

08 . Costuma ter os pés ou pernas inchadas?

09. Tem tosse persistente com frequência?

10. Alguma vez escarrou sangue?

11. Você é diabético?

12. Costuma sentir muita sede?

13. Quando se fere, as feridas demoram a cicatrizar?

14. Sangra muito quando se fere ou extrai dente?

15. Tem algum tipo de alergia?

16. Alguma vez precisou tomar transfusão de sangue?

17. Alguma vez tomou Penicilina (Benzetacil)?

18. Tem algum problema de estômago (gastrite, úlcera, etc...)?

19. Você está grávida?

Outras informações que julgar importante referir:

Declaro que o respondido acima é verdadeiro.

São Paulo, de de 2.0

$R G n^{\circ}$ 


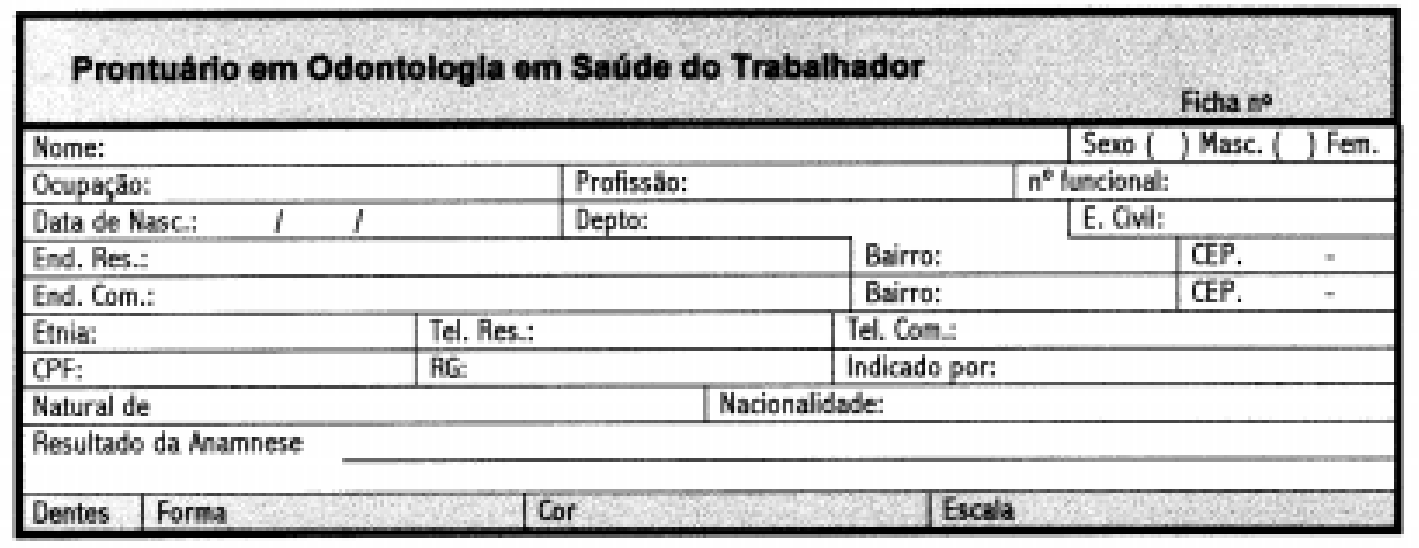

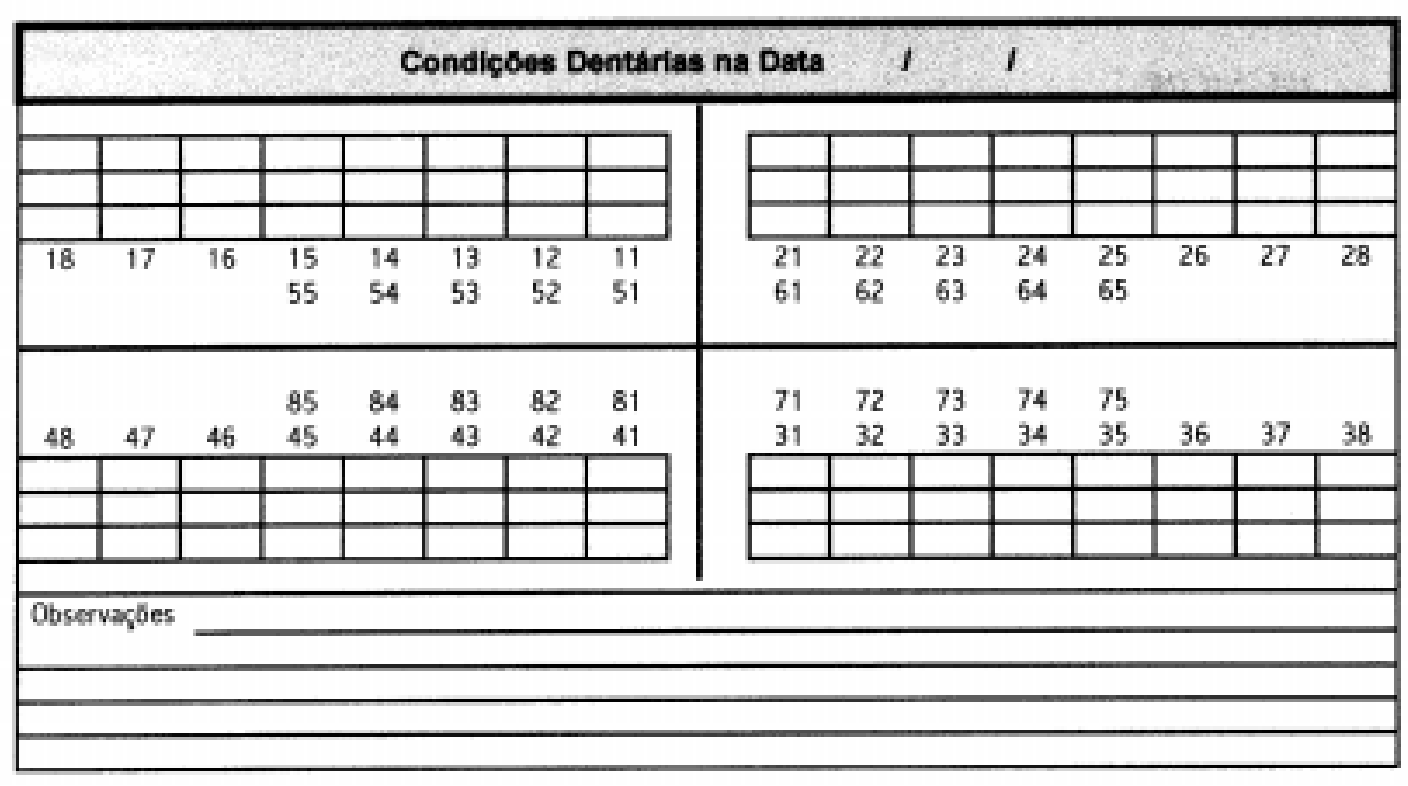

Data Dats

MPOMACABDABAAAGME

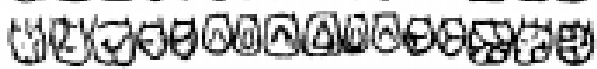
भध由 (स)

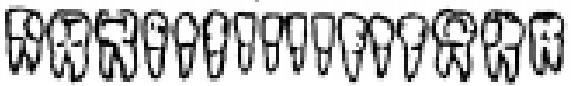

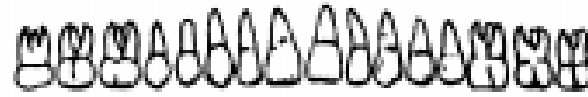

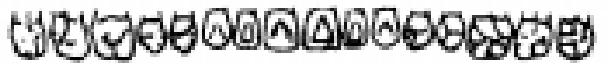

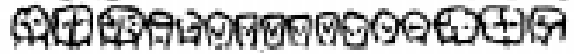
क्ष 


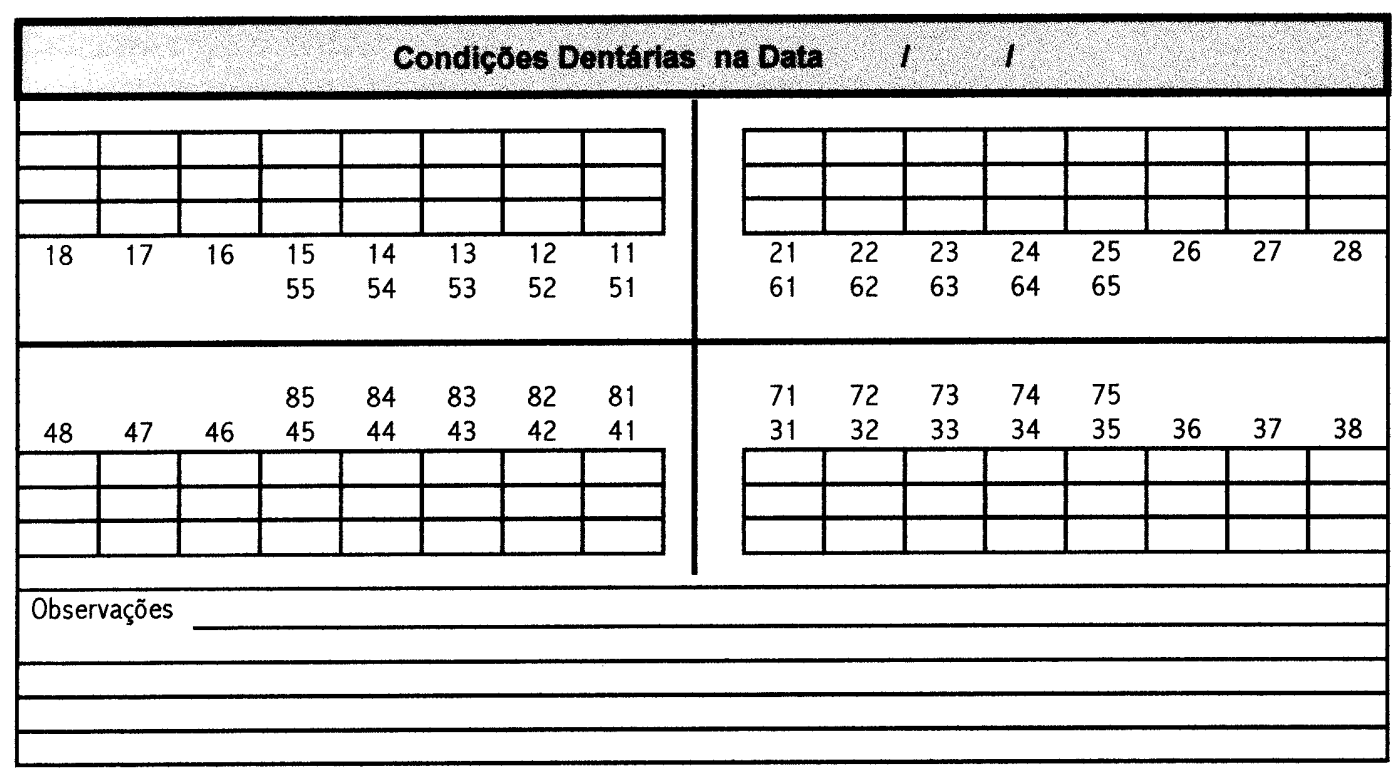

Ciéncia do Trabalhador

Declaro estar ciente das minhas condições bucais e havendo sido esclarecido sobre os problemas diagnosticados, comprometo-me a procurar tratamento odontológico para resolvê-los.

São Paulo, de de 2.0

$R G n^{\circ}$

Assinatura do paciente ou responsável

\begin{tabular}{|l|l|l|l|}
\hline Data & Regiåo & Procedimento & CD \\
\hline & & & \\
\hline & & & \\
\hline & & & \\
\hline & & & \\
\hline & & & \\
\hline & & & \\
\hline & & & \\
\hline & & & \\
\hline & & & \\
\hline & & & \\
\hline & & & \\
\hline & & & \\
\hline
\end{tabular}




\title{
Código para o preenchimento do odontograma do Prontuário
}

\author{
c Canais tratados - radiografias - outras observações \\ $\mathrm{b}$ \\ Material utilizado ou cárie \\ a \\ Faces restauradas ou trabalhos envolvendo o elemento dentário, ou exodontias.
}

Espaço (a)

- Faces:

$$
\begin{aligned}
& \mathrm{O}=\text { oclusal } \\
& \mathrm{M}=\text { mesial } \\
& \mathrm{V}=\text { vestibular }
\end{aligned}
$$$$
\mathrm{I}=\text { incisal }
$$$$
\mathrm{D}=\text { distal }
$$$$
\mathrm{L}=\text { lingual }
$$

- Trabalhos envolvendo os elementos:

$$
\begin{aligned}
& \text { CO - coroa } \\
& \text { PFP - ponte fixa pilar } \\
& \text { PF - ponte fixa elemento suspenso } \\
& \text { CP - coroa pivô } \\
& \text { PRG - ponte removível indicando elemento como grampo } \\
& \text { PR - ponte removivel elementos colocados } \\
& \text { Exo - Exodontia } \\
& \text { R - Raiz }
\end{aligned}
$$

Espaço (b) - Material utilizado:

Ag - amálgama

$\mathrm{Si}$ - cimento de silicato

$\mathrm{Au}-$ ouro

LNA - liga não áurica

RA - resina acrílica

$\mathrm{RC}$ - resina composta

RCF - resina composta fotopolimerizável

MP - metaloplástica Venner

MC - metalocerâmica

$\mathrm{P}$ - porcelana

$\mathrm{N}$ - núdeo

etc.

OBS.: Caso tenha sido utilizado algum outro material, escrever por extenso no espaço ou fazer a citação no espaço de observações.

Cáries: "C - cárie"

\section{Espaço (c)}

Tratamento de 1 conduto - 1C

Tratamento de 2 condutos - $2 \mathrm{C}$

Tratamento de 3 condutos - 3C

$\mathrm{RX}$ - se houver radiografia daquele elemento

INCL - dente incluso

$\mathrm{S}$ - INCL - dente semi-incluso

NOTA: Observar que, sendo esta uma ficha odontolegal, os trabalhos não codificados devem ser descritos minuciosamente na parte referente a observações (próteses totais, aparelhos ortodônticos, forma do arco, anodontias, dentes extranumerários, etc.). 
FICHA COMPLEMENTAR DA ANAMNESE

Identificação

Nome:

$n^{\circ}$ funcional:

Depto.:

Data:

Queixa Principal / Duração

\begin{tabular}{|l|}
\hline \\
\hline
\end{tabular}

História da Doença Atual

\begin{tabular}{|l|}
\hline \\
\hline \\
\hline \\
\hline
\end{tabular}

Antecedentes Familiais / Situação Familiar

\begin{tabular}{|l|}
\hline \\
\hline
\end{tabular}

Antecedentes Mórbidos Pessoais

Hábitos / Vícios

Observações 
EXAME FísICo

\section{A) GERAL}

B) REGIONAL

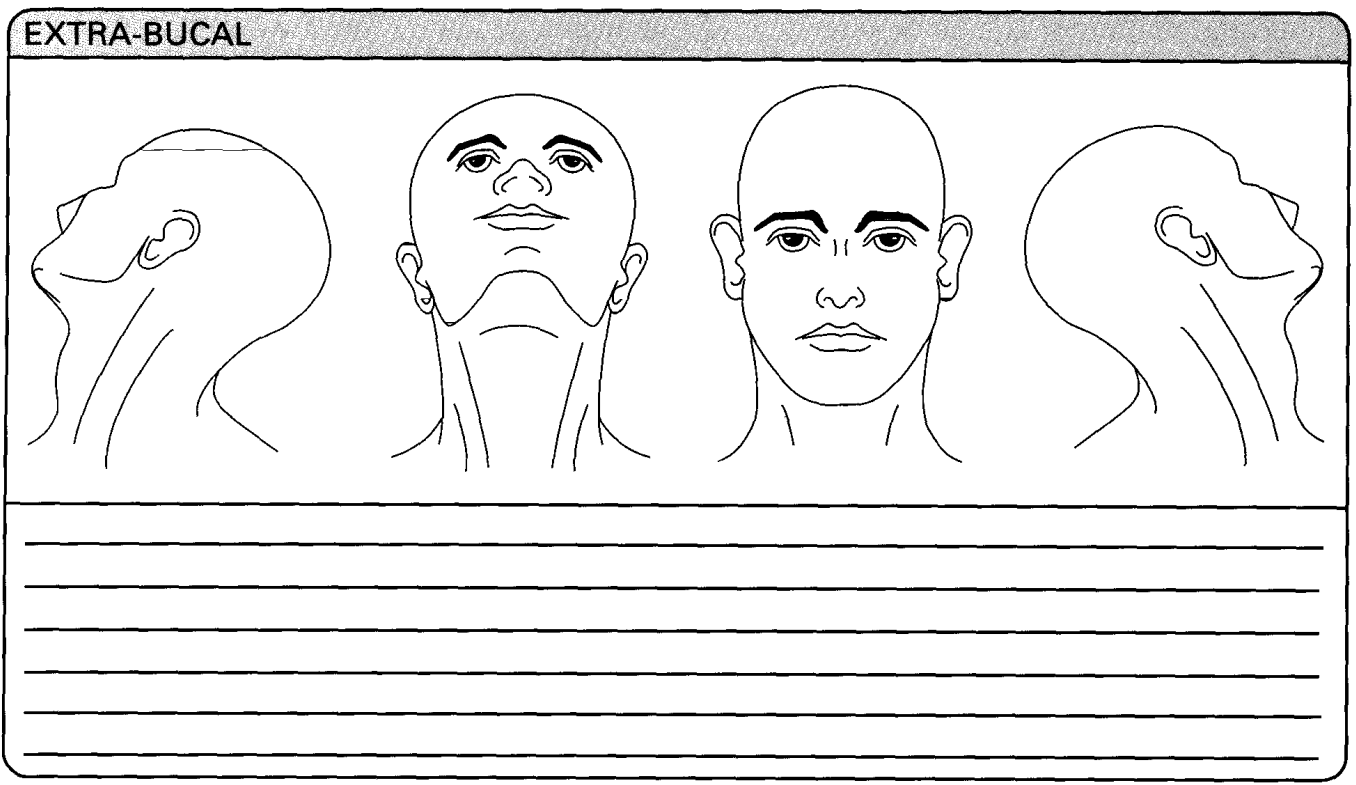

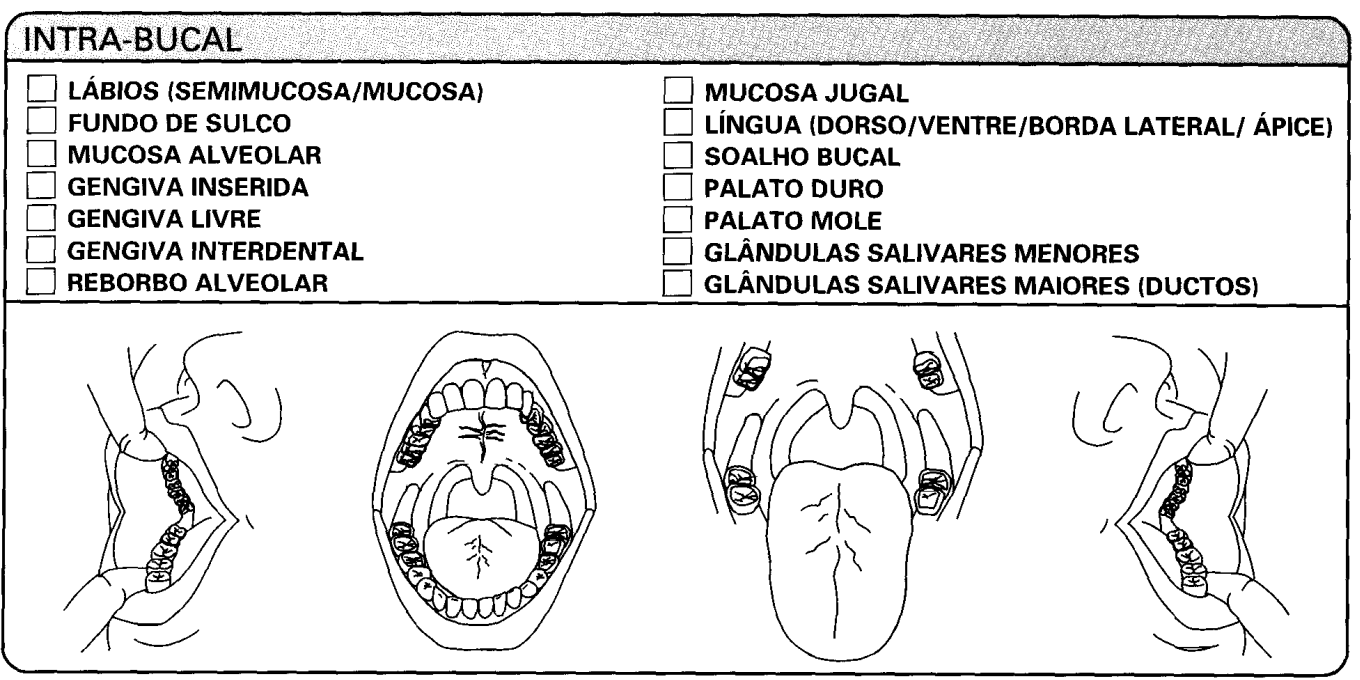




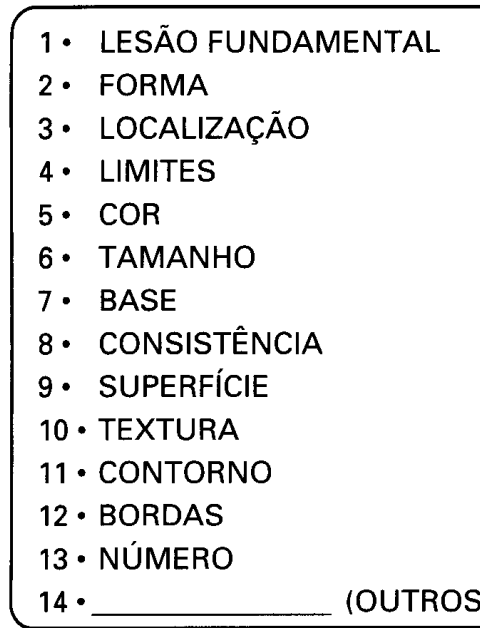

\section{HIPÓTESES DE DIAGNÓSTICO/DIAGNÓSTICO CLÍNICO}

\section{EXAMES COMPLEMENTARES SOLICITADOS E/OU REALIZADOS}

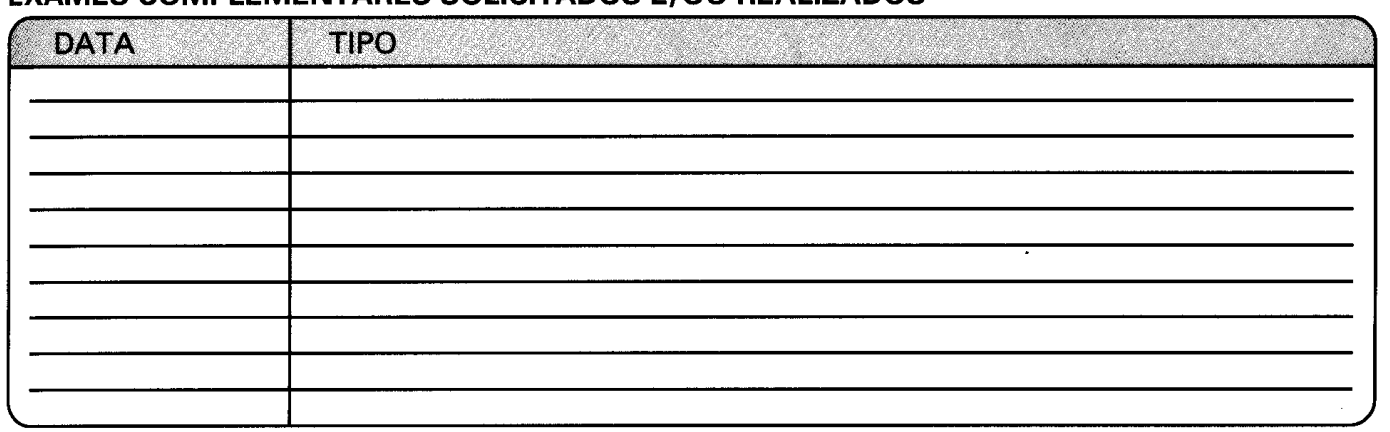

\section{RESULTADO DE EXAMES}

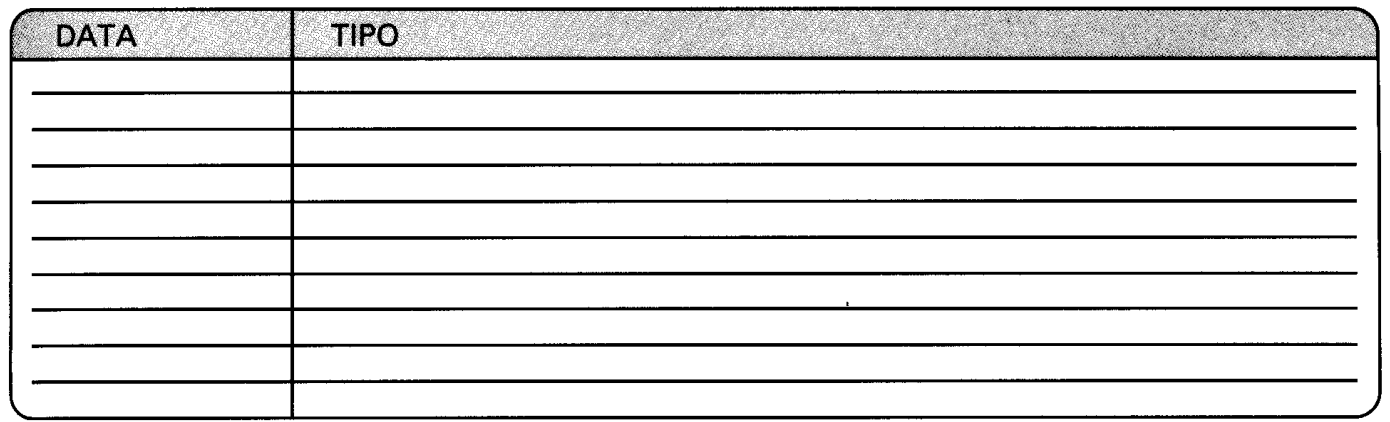

DIAGNÓSTICO FINAL

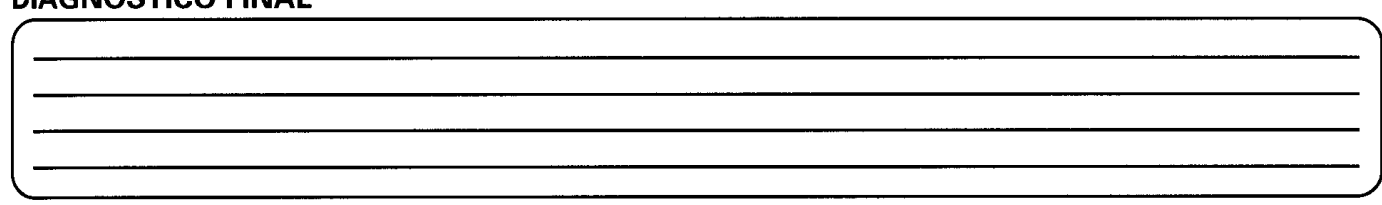


a. DANO ANATÓMICO

D. DANO FUNCIONAL

c. EFETMIOADE DOS RECURSOS TERAPEUTICOS

d. CONDIÇOES OAGANNICAS DO PACIENTE

e. TIPO DA DOENCA

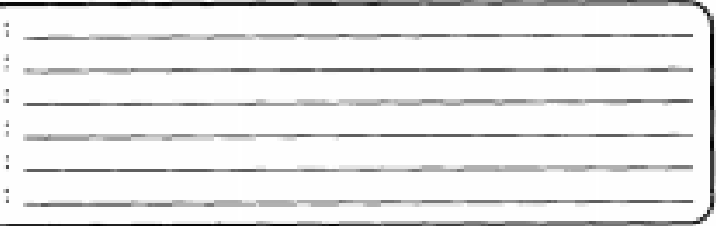

\section{TRATAMENTO}

a. SUPORTE

b. EXPECTANTE

c. SINTOMÁTICO

d. ENOLÓGICO

a. PRONA TERAPEUTICA

t. CIAÜRGICO

\section{$\mathrm{X}$ - OBSEavacóes}

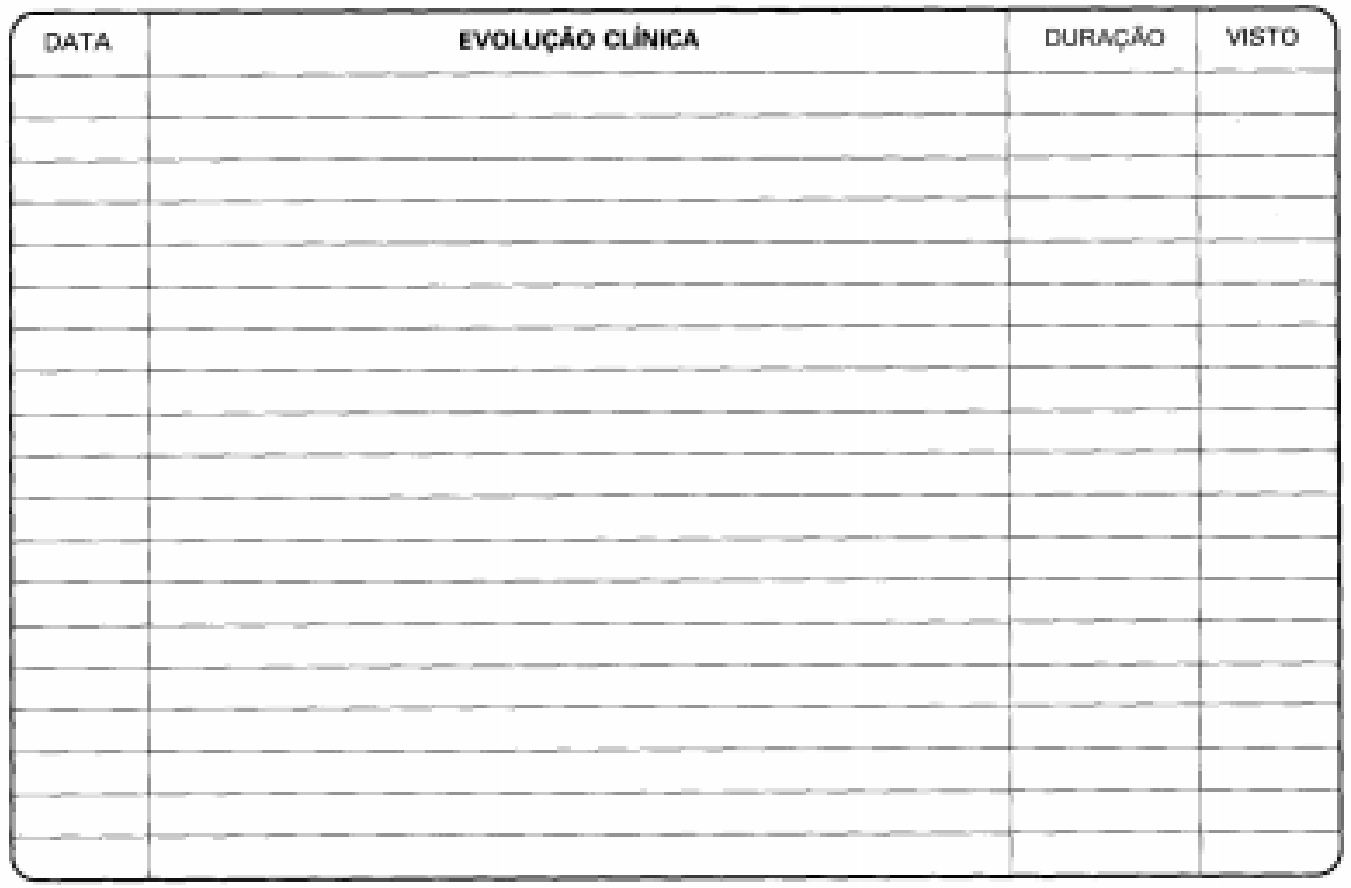

(Boraks, 1999) 


\begin{abstract}
ANEXO 9
Manifestação oral de Doenças Profissionais de acordo com agente e ocupação. (adaptado de Schour e Sarnat)
\end{abstract}

\begin{tabular}{|c|c|c|}
\hline AGENTES & $\begin{array}{c}\text { MANIFESTAÇÕES } \\
\text { BUCAIS }\end{array}$ & OCUPAÇÕES \\
\hline Apreensão de Objetos & $\begin{array}{l}\text { Abrasão localizada } \\
\text { Abrasão localizada,alteração da } \\
\text { musculatura buco-facial, } \\
\text { pneumatocele e lábio inferior } \\
\text { congesto e edemaciado }\end{array}$ & $\begin{array}{l}\text { Costureiras, Carpinteiros, } \\
\text { Tarrafeiros, Tipógrafos, etc. } \\
\text { Músicos (instrumentos de sopro) } \\
\text { e sopradores de vidro }\end{array}$ \\
\hline $\begin{array}{l}\text { Blastomicose Sul-Americana } \\
\text { (Paracoccidiodes brasilienses) }\end{array}$ & $\begin{array}{l}\text { Lesões erosivas ou ulceradas, cor } \\
\text { esbranquiçada, superfície } \\
\text { granulosa e com pontos } \\
\text { hemorrágicos, dor, ardor, prurido, } \\
\text { sialorréia, odontalgia, gengivas } \\
\text { inflamadas (hemorrágicas e/ou } \\
\text { retração gengival), enfartamento } \\
\text { ganglionar e agravamento do } \\
\text { estado geral }\end{array}$ & Trabalhadores agrícolas \\
\hline Alcatrão & $\begin{array}{l}\text { Estomatites, carcinoma de lábio e } \\
\text { mucosa }\end{array}$ & $\begin{array}{l}\text { Pescadores, Trabalhadores com } \\
\text { asfalto e alcatrão, Calceteiros, } \\
\text { Telhadores com piche e } \\
\text { Preservadores de madeira }\end{array}$ \\
\hline Inorgânico (cobre, ferro, níquel ) & $\begin{array}{l}\text { Manchas verdes nos dentes, } \\
\text { pigmentações na gengiva, } \\
\text { gengivoestomatite }\end{array}$ & $\begin{array}{l}\text { Bronzeadores, Trabalhadores } \\
\text { com cimento, Gravadores e } \\
\text { Mineiros }\end{array}$ \\
\hline $\begin{array}{l}\text { Orgânico ( osso, celulóide, } \\
\text { serragem, farinha, tabaco ) }\end{array}$ & $\begin{array}{l}\text { Pigmentação dos dentes e } \\
\text { gengiva, abrasão generalizada, } \\
\text { gengivoestomatite, hemorragia }\end{array}$ & $\begin{array}{l}\text { Trabalhadores em osso, } \\
\text { celulóide,serragem, farinha, } \\
\text { tabaco }\end{array}$ \\
\hline \multirow[t]{2}{*}{ Arsênico } & $\begin{array}{l}\text { Gosto metálico, sialorréia, } \\
\text { gengiva edemaciada, mucosa } \\
\text { ulcerada, erosões } \\
\text { esbranquiçadas, ardor local, } \\
\text { necrose pulpar, necrose óssea, } \\
\text { periostite }\end{array}$ & $\begin{array}{l}\text { Trabalhadores com produtos } \\
\text { químicos, refinadores, } \\
\text { siderúrgicos,fabricantes de } \\
\text { inseticidas }\end{array}$ \\
\hline & $\begin{array}{l}\text { Hemorragias, edemas, } \\
\text { gengivoestomatite, pigmentação }\end{array}$ & \\
\hline
\end{tabular}




\begin{tabular}{|c|c|c|}
\hline Bismuto & $\begin{array}{l}\text { da mucosa bucal e gengival (linha } \\
\text { de bismuto), coloração negro- } \\
\text { azulado (papila e geng. marginal), } \\
\text { sensação de ardor, gosto } \\
\text { metálico }\end{array}$ & $\begin{array}{l}\text { Manipuladores de bismuto, } \\
\text { Fabricantes de pós }\end{array}$ \\
\hline Cromo & $\begin{array}{l}\text { Necrose óssea, ulceração dos } \\
\text { tecidos bucais, manchas } \\
\text { amarelas nos dentes }\end{array}$ & $\begin{array}{l}\text { Trabalhadores com compostos de } \\
\text { anilina, cromo, aço, máquina } \\
\text { fotográfica, impressores e } \\
\text { misturadores de borracha }\end{array}$ \\
\hline Flúor & $\begin{array}{l}\text { Osteoclerose, perda de } \\
\text { tranparência do esmalte, } \\
\text { sialorréia }\end{array}$ & Trabalhadores com criolita \\
\hline Chumbo & $\begin{array}{l}\text { Linha de Burton (acinzentada), } \\
\text { hálito fétido, gosto metálico, } \\
\text { gengivoestomatite, sialorréia, } \\
\text { aumento de volume das } \\
\text { glândulas salivares, parotidite }\end{array}$ & $\begin{array}{l}\text { Gravadores, Fabr. de inseticidas, } \\
\text { Acumuladores elétricos, } \\
\text { Refinadores de chumbo, } \\
\text { Impressores }\end{array}$ \\
\hline Mercúrio & $\begin{array}{l}\text { Sialorréia, gengivoestomatite, } \\
\text { osteomielite, dentes enegrecidos, } \\
\text { parotidite, afrouxamento dental, } \\
\text { gosto metálico, orla azul escura } \\
\text { (colo dos dentes) }\end{array}$ & $\begin{array}{l}\text { Bronzeadores (cano de arma), } \\
\text { Fabricantes de tintas e baterias, } \\
\text { DENTISTAS, detonadores, } \\
\text { Trabalhadores com explosivos }\end{array}$ \\
\hline Fósforo & $\begin{array}{l}\text { Gengivoestomatite, halitose, } \\
\text { descalcificação, cárie e perda } \\
\text { gradual dos dentes, ulceração } \\
\text { dos tecidos bucais, osteomielites } \\
\text { (supuração alvéolo-dentário com } \\
\text { exsudato purulenta fosforecente) }\end{array}$ & $\begin{array}{l}\text { Fundidores de latão, } \\
\text { Trabalhadores em fábrica de } \\
\text { fósforo, em bronze fosforoso, } \\
\text { Fabr. de fertilizante e fogos de } \\
\text { artifício }\end{array}$ \\
\hline Prata & $\begin{array}{l}\text { gengivite, halitose, sialorréia, } \\
\text { gengiva com orla empardecida, } \\
\text { pigmentação da pele e mucosa }\end{array}$ & Indústria química \\
\hline Açúcar & Cárie e periodontite & $\begin{array}{l}\text { Refinadores, padeiros e } \\
\text { confeiteiros }\end{array}$ \\
\hline Anilina & $\begin{array}{l}\text { Coloração azul dos lábios e } \\
\text { gengiva }\end{array}$ & $\begin{array}{l}\text { Trabalhadores com alcatrão, de } \\
\text { hulha, explosivos, pintores, } \\
\text { curtidores e vulcanizadores }\end{array}$ \\
\hline Benzeno & $\begin{array}{l}\text { Hemorragia gengival, estomatite, } \\
\text { hálito e gosto benzóico, } \\
\text { osteomielite dos maxilares }\end{array}$ & $\begin{array}{l}\text { Trabalhadores com coque, } \\
\text { metalúrgico e laca, lavagem } \\
\text { seca, vulcanizadores, fabr. de } \\
\text { pólvora sem fumaça }\end{array}$ \\
\hline Fenol & $\begin{array}{l}\text { metacromasia amarela dos } \\
\text { dentes, gosto amargo }\end{array}$ & Indústria química (desinfetante) \\
\hline
\end{tabular}




\begin{tabular}{|c|c|c|}
\hline Cresol & Estomatite & $\begin{array}{l}\text { Trabalhadores com alcatrão, } \\
\text { hulha, borracha, destilaria, } \\
\text { curativos cirúrgicos de } \\
\text { desinfetantes }\end{array}$ \\
\hline Variação de pressão & $\begin{array}{l}\text { Sangramento gengival, } \\
\text { odontalgias }\end{array}$ & Mergulhadores, aviadores \\
\hline $\begin{array}{c}\text { Ácidos }\left(\mathrm{H}_{2} \mathrm{SO}_{4}, \mathrm{HNO}_{3}, \mathrm{HCl}, \mathrm{HF} \text {, }\right. \\
\text { etc. })\end{array}$ & $\begin{array}{l}\text { Descalcificação do esmalte, } \\
\text { osteomielite, hemorragia } \\
\text { gengival, estomatite, ulceração }\end{array}$ & $\begin{array}{l}\text { Manejo de ácidos em cartuchos, } \\
\text { refinadores de petróleo, } \\
\text { trabalhadores com explosivos e } \\
\text { algodão }\end{array}$ \\
\hline Calor & dores nos maxilares & Foguistas, ferreiros, bombeiros \\
\hline Frio & $\begin{array}{l}\text { Afecções dos dentes, articulações } \\
\text { e ossos maxilares, afrouxamento } \\
\text { dos dentes, queda de } \\
\text { restaurações }\end{array}$ & $\begin{array}{l}\text { Indústria com câmara frigorífica } \\
\text { (enlatados, matadouros, sorvete) }\end{array}$ \\
\hline $\begin{array}{l}\text { Monóxido de carbono, dióxido de } \\
\text { carbono }\end{array}$ & $\begin{array}{l}\text { Cárie, inflamação gengival, queda } \\
\text { precoce dos dentes, debilidade } \\
\text { da musculatura da língua e rosto }\end{array}$ & $\begin{array}{l}\text { Mineiros, fundidores, } \\
\text { trabalhadores com motor à } \\
\text { gasolina }\end{array}$ \\
\hline Radio, Raios X & $\begin{array}{l}\text { Candidíase, gengivite, } \\
\text { periodontopatias, xerostomia } \\
\text { (cárie de irradiação), } \\
\text { osteorradionecrose, etc. }\end{array}$ & $\begin{array}{l}\text { Técnicos, pintores de } \\
\text { mostradores de relógio, } \\
\text { pesquisadores,DENTISTAS }\end{array}$ \\
\hline
\end{tabular}




\title{
ANEXO 10
}

\author{
DIÁRIO OFICIAL \\ I2de maio de 1999 \\ Página 1 \\ Secão 1

\section{Atos do Poder Executivo Decreto $\mathrm{n}^{\circ}$ 3.048, de 6 de maio de $1999\left(^{*}\right)$}

Aprova o Regulamento da Previdência Social, e dá outras providências.

O Presidente da República, no uso da atribuição que lhe confere o art. 84, inciso IV, da Constituição Federal, e de acordo com a Emenda Constitucional $n^{\circ}$ 20, de 1998, as Leis Complementares $n^{\circ} 70$, de 30 de dezembro de 1991, e 84, de 18 de janeiro de 1996, e as Leis $n^{\circ} 8.138$, de 28 de dezembro de 1990, 8.212, de 24 de julho de 1991, 8.213, de 24 de julho de 1991, 8.218, de 29 de agosto de 1991, 8.383, de 30 de dezembro de 1991, 8.398, de 7 de janeiro de 1992, 8.436, de 25 de junho de 1992, 8.444, de 20 de julho de 1992, 8.540, de 22 de dezembro de 1992, 8.542, de 23 de dezembro de 1992,8.619, de 5 de janeiro de 1993, 8.620, de 5 de janeiro de 1993, 8.630, de 25 de fevereiro de 1993, 8.647, de 13 de abril de 1993, 8.742, de 7 de dezembro de 1993, 8.745, de 9 de dezembro de 1993, 8.861, de 25 de março de 1994,8.864, de 28 de março de 1994, 8.870, de 15 de abril de 1994, 8.880, de 27 de maio de 1994, 8.935, de 18 de novembro de 1994,8.981, de 20 de janeiro de 1995, 9.032, de 28 de abril de 1995, 9.063, de 14dejunhode 1995, 9.065, de 20 de junho de 1995, 9.069, de 29 de junho de 1995, 9.129, de 20 de novembro de 1995, 9.249, de 26 de dezembro de 1995, 9.250, de

26 de dezembro de 1995, 9.317, de 5 de dezembro de 1996, 9.429, de 26 de dezembro de 1996, 9.476, de 23 de julho de 1997, 9.506, de 30 de outubro de 1997, 9.528, de 10 de dezembro de 1997, 9.601, de 21 de janeiro de 1998, 9.615, de 24 de março de 1998, 9.639, de 25 de maio de 1998,9.649, de 27 de maio de 1998,9.676, de 30 de junho de 1998,9.703, de 17 de novembro de 1998, 9.711, de 21 de novembro de 1998, 9.717, de 27 de novembro de 1998, 9.718, de 27 de novembro de 1998, 9.719, de 27 de novembro de 1998, 9.720, de 30 de novembro de 1998, e 9.732, de 11 de dezembro de 1998 ,

Decreta:

Art. $1^{\circ}$ O Regulamento da Previdência Social passa a vigorar na forma do texto apenso ao presente Decreto, com seus anexos.

Art. $2^{\mathbf{0}}$ Este Decreto entra em vigor na data de sua publicação.

Art. $3^{\mathbf{o}}$ Ficam revogados os Decretos $\mathrm{n}^{\circ}$ 33.335, de 20 de julho de 1953, 36.911, de 15 de fevereiro de 1955,65.106, de 5 de setembro de 1969, 69.382, de 19 de outubro de 1971, 72.771, de 6 de setembro de 1973, 73.617, de 12 de fevereiro de 1974,73.833, de 13 de março de 1974, 74.661, de 7 de outubro de 1974, 75.478, de 14 de março de 1975, 75.706, de 8 de maio de 1975, 75.884, de 19 de junho de 1975, 76.326, de 23 de setembro de 1975, 77.210, de 20 de fevereiro de 1976, 79.037, de 24 de dezembro de 1976, 79.575, de 26 de abril de 1977, 79.789, de 7 de junho de 1977, 83.080, de 24 de janeiro de 1979, 83.081, de 24 de janeiro de 1979, 85.745, de 23 de fevereiro de 1981, 85.850, de 30 de março 1981, 86.512, de 29 de outubro de 1981, 87.374, de 8 de julho de $1982,87.430$, de 28 de julho de 1982, 88.353, de 6 de junho de 1983, 88.367, de 7 de junho de $1983,88.443$, de 29 de junho de 1983, 89.167, de 9 de dezembro de 1983, 89.312, de 23 de janeiro de 1984,90.038, de 9 de agosto de 1984,90.195, de 12 de setembro de 1984, 90.817, de 17 de janeiro de 1985, 91.406, de 5 de julho de 1985, 92.588, de 25 de abril de 1986, 92.700, de 21 de maio de 1986,92.702, de 21 de maio de 1986, 92.769, de 10 de junho de 1986, 92.770, de 10 de junho de 1986, 92.976, de 22 de julho de 1986,94.512, de 24 de junho de 1987, 96.543, de 22 de agosto de 1988, 96.595, de 25 de agosto de 1988, 98.376, de 7 de novembro de 1989,99.301, de 15 de junho de 1990, 99.351, de 27 de junho 1990, 1.197, de 14 de julho de 1994,1.514, deSde junho de 1995,1.826, de 29 de fevereiro de 1996, 1.843, de 25 de março de 1996, 2.172, deSde março de 1997, 2.173, de 5 de março de 1997,2.342, de 9 de outubro de 1997, 2.664, de iOdejulhode 1998, 2.782, de 14 de setembro de 1998, 2.803, de 20 de outubro de 1998, 2.924, de 5 de janeiro de 1999, e 3.039, de 28 de abril de 1999 .

Brasília, 6 de maio de 1999; $178^{\circ}$ da Independência e $111^{\circ}$ da República.

Fernando Henrique Cardoso

Waldeck Ornélas

(*) republicado por ter saído com incorreção no Diário Oficial de 7 de maio de 1999, Seção 1, páginas 50 a 108. 


\title{
REGULAMENTO DA PREVIDENCIA SOCIAL
}

\author{
ANEXO III \\ RELAÇÃO DAS SITUAÇÕES QUE DÃO DIREITO AO AUXÍLIO- \\ ACIDENTE
}

\section{QUADRO N 1}

Aparelho visual

Situações:

a) acuidade visual, após correção, igual ou inferior a 0,2 no olho acidentado;

b) acuidade visual, após correção, igual ou inferior a 0,5 em ambos os olhos, quando ambos tiverem sido acidentados;

c) acuidade visual, após correção, igual ou inferior a 0,5 no olho acidentado, quando a do outro olho for igual a 0,5 ou menos, após correção;

d) lesão da musculatura extrinseca do olho, acarretando paresia ou paralisia;

e) lesão bilateral das vias lacrimais, com ou sem fistulas, ou unilateral com fistula.

NOTA 1 - A acuidade visual restante é avaliada pela escala de Wecker, em décimos, e após a correção por lentes.

NOTA 2- A nubécula e o leucoma são analisados em função da redação da acuidade ou do prejuizo estético que acarretam, de acordo com os quadros respectivos.

\section{QUADRO N 2}

\section{Aparelho auditivo}

\section{TRAUMA ACÚSTICO}

a) perda da audição no ouvido acidentado;

b) redução da audição em grau médio ou superior em ambos os sonidos, quando os dois tiverem sido acidentados:

c) redução da audição, em grau médio ou superior, no ouvido acidentado, quando a audição do outro estiver também reduzida em grau médio ou superior.

NOTA 1 - A capacidade auditiva em cada ouvido é avaliada mediante audiometria apenas aérea, nas frequiências de 500, 1.000, 2.000 e 3.000 Hertz.

NOTA 2 - A redução da audição, em cada ouvido, é avaliada pela média aritmética dos valores, em decibéis, encontrados nas frequiências de 500, 1.000, 2,000 e 3.000 Hertz, segundo adaptação da classificação de Ouvis \& Silvermann, 1970.

Audição normal - até vinte e cinco decibéis.

Redução em grau mínimo - viste e seis a quarenta decibéis;

Redução em grau médio - quarenta e um a setenta decibéis;

Redução em grau máximo - setenta e um a noventa decibéis; 
Perda de audição - inalo de noventa decibéis.

\section{QUADRO No 3}

Situação:

Perturbação da palavra em grau médio ou máximo, desde que comprovada por métodos clínicos objetivos.

\section{QUADRO Nº 4}

\section{Prejuízo estético}

Situações:

Prejuízo estético, em grau médio ou máximo, quando atingidos crânio, e/ou face, e/ou pescoço ou perda de dentes quando há também deformação da arcada dentária que impede o uso de prótese.

NOTA 1 - Só é considerado como prejuízo estético a lesão que determina apreciável modificação estética do segmento corpóreo atingido, acarretando aspecto desagradável. tendo-se em conta sexo, idade e profissão do acidentado.

NOTA 2 - A perda anatômica de membro, a redução de movimentos articulares ou a alteração da capacidade funcional de membro não são considerados como prejuízo estético, podendo, porém, ser enquadradas, se for o caso, nos quadros respectivos.

\section{QUADRO No 5}

Situações:

\section{Perdas de segmentos de membros}

a) perda de segmento ao nível ou acima do carpo;

b) perda de segmento do primeiro quirodáctilo, desde que atingida a falange distal;

c) perda de segmentos de dois quirodáctilos, desde que atingida a falange distal em pelo menos um deles,

d) perda de segmento do segundo quirodáctilo, desde que atingida a falange distal;

e) perda de segmento de três ou mais falanges, de três ou mais quirodáctilos:

f) perda de segmento ao nível ou acima do fumo;

g) perda de segmento do primeiro pododáctilo, desde que atingida a falange distal;

h) perda de segmento de dois pododáctilos, desde que atingida a falange distal em ambos;

i) perda de segmento de três ou mais falanges, de três ou mais pododáctilos.

NOTA: Para efeito de enquadramento, a perda parcial de parte óssea de um segmento equivale á perda do segmento. A perda parcial de partes motes sem perda de parte óssea do segmento não é onsiderada para efeito de enquadramento.

\section{QUADRO N 6}


Situações:

\section{Alterações articulares}

a) redução em grau médio ou superior dos movimentos da mandíbula;

b) redução em grau máximo dos movimentos do segmento cervical da coluna vertebral;

c) redução em grau máximo dos movimentos do segmento lombo-sacro da coluna vertebral:

d) redação em grau médio ou superior dou movimentos das articulações do ombro ou do cotovelo;

e) redação em grau médio ou superior dos movimentos de pronação e/ou de supinação do antebraço:

f) redução em grau máximo dou movimentos do primeiro e/ou do segundo quirodáctilo, desde que atingidas as articulações metacarpo-falangeana e falangefalangeana;

g) redução em grau médio ou superior dos movimentos das articulações coxofemural e/ou joelho, e/ou tibio-társica,

NOTA 1 Os gruas de redução de movimentos articulares referidos neste quadro são avaliados de acordo com os seguintes critérios:

Grau máximo: redução acima de dois terços da amplitude normal do movimento da articulação;

Grau médio: redução de mais de um terço e até dois terços da amplitude normal do movimento da articulação;

Grau mínimo: redução de até um terço da amplitude normal do movimento da articulação.

NOTA 2 - A redução de movimentos do cotovelo, de pronação e supinação do antebraço, punho, joelho e tíbio-társica, secundária a uma fratura de osso longo do membro, consolidada em posição viciosa e com desvio de eixo, também é enquadrado dentro dos limites estabelecidos.

\section{OUADRO $\mathrm{N}^{\circ} 7$}

\section{Encurtamento de membro inferior}

Situação:

Encurtamento de mais de $4 \mathrm{~cm}$ (quatro centímetros).

NOTA: A preexistência de lesão de bacia deve ser considerada quando da avaliação do encurtamento.

\section{QUADRO N 8}

$\underline{\text { Redução da forço e/ou da capacidade funcional dos membros }}$

Situações:

a) redução da torça e/ou da capacidade funcional da mão, do punho, do antebraço ou de todo o membro superior em grau sofrível ou interior da classificação de desempenho muscular;

b) redução da forço e/ou da capacidade funcional do primeiro quirodáctilo em grau sofrível ou inferior: 
c) redução da força e/ou da capacidade funcional do pé, da perna ou de todo o membro inferior em grau sofrível ou inferior.

NOTA 1 -Esta classificação se aplica a situações decorrentes de comprometimento muscular ou neurológico. Não se aplica a alterações decorrentes de lesões articulares ou de perdes anatômicas constantes dos quadros próprios.

NOTA 2 - Na avaliação de redação da torça ou de capacidade funcional é utilizada a classificação da carta de desempenho muscular da The National Foundation for Infantile Paralysis, adotada pelas Sociedades Internacionais de Ortopedia e Traumatologia, e a seguir transcrita:

Desemoenho muscular

Grau 5- Norrnal - cem por cento - Amplitude completa de movimento contra a gravidade e contra grande resistência.

Grau 4- Bom - setenta e cinco por cento - Amplitude completa de movimento contra a gravidade e contra alguma resistência.

Grau 3- Sofrível -cinquienta por cento - Amplitude completa de movimento contra a gravidade sem opor resistência.

Grau 2 - Pobre - vinte e cinco por cento - Amplitude completa de movimento quando eliminada a gravidade.

Grau 1 - Traços - dez por cesto - Evidência de leve contração. Nenhum movimento articular.

Grou O (zero) - zero por cento - Nenhuma evidência de contração.

Grau E ou EG - zero por cento - Espasmo ou espasmo grave.

Grau C ou CG - Contratura ou contratura grave.

NOTA - O enquadramento dos casou degrau sofrível ou inferior abrange, na prática, os casos de redução em que há impossibilidade de movimento contra alguma força de resistência além da torça de gravidade.

\section{QUADRO N9}

\section{Outros aparelhos e sistemas}

Situações:

a) segmentectomia pulmonar que acarrete redução em grau média ou superior da capacidade funcional respiratória; devidamente correlacionada à sua atividade laborativa.

b) perda do segmento do aparelho digestivo cuja localização ou extensão traz repercussões sobre a nutrição e o estado geral.

\section{B- DOENÇAS PROFISSIONAIS E AS DO TRABALHO}

As doenças profissionais e as do trabalho, que após consolidações das lesões resultem seqüielas permanentes com redução da capacidade de trabalho, deverão ser enquadradas conforme o art. 104 deste Regulamento. 


\section{ANEXO 11}

\section{DIÁRIO OFICIAL}

19 de novembro de 1999

Página 21

Ministério da Saúde

Gabinete do Ministro

Portaria n 1.339 , de 18 de novembro de 1999

O Ministro de Estado da Saúde, no uso de suas atribuições, e considerando o artigo 60, parágrafo 30 inciso VII da Lei $n^{\circ} 8.080 / 90$, que delega ao Sistema Único de Saúde - SUS a revisão periódica da listagem oficial de doenças originadas no processo de trabalho;

a Resolução do Conselho Nacional de Saúde, n 220, de 05 de maio de 1997, que recomenda ao Ministério da Saúde a publicação da Lista de Doenças relacionadas ao Trabalho;

a importância da definição do perfil nosológico da população trabalhadora para o estabelecimento de políticas públicas no campo da saúde do trabalhador, resolve:

Art. $1^{\circ}$ Instituir a Lista de Doenças relacionadas ao Trabalho, a ser adotada como referência dos agravos originados no processo de trabalho no Sistema Único de Saúde, para uso clínico e epidemiológico, constante no Anexo 1 desta Portaria.

Art. $2^{\circ}$ Esta lista poderá ser revisada anualmente.

Art. $3^{\circ}$ Esta Portaria entra em vigor na data de sua publicação.

\section{JOSÉ SERRA}

\section{LISTA DE DOENÇAS RELACIONADAS AO TRABALHO}

Relação de Agentes ou Fatores de Risco de Natureza Ocupacional, com as Respectivas Doenças que podem estar com eles relacionadas

\begin{tabular}{|c|c|}
\hline $\begin{array}{c}\text { Agentes Etiológicos ou Fatores de Risco } \\
\text { de Natureza Ocupacional }\end{array}$ & $\begin{array}{c}\text { Doenças Causalmente Relacionadas com } \\
\text { os Respectivos Agentes ou Fatores de } \\
\text { Risco (denominadas e codificadas } \\
\text { segundo a CID-1O) }\end{array}$ \\
\hline $\begin{array}{l}\text { 1) Arsênio e seus compostos } \\
\text { arsenicais }\end{array}$ & 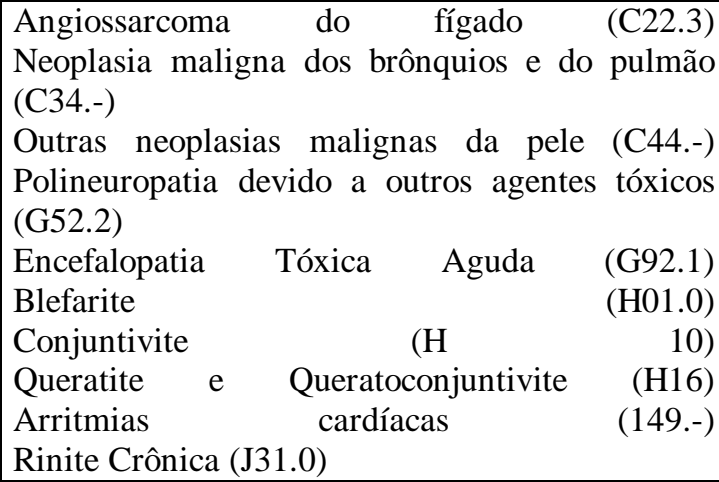 \\
\hline
\end{tabular}




\begin{tabular}{|c|c|c|c|}
\hline $\begin{array}{l}\text { 3) Benzeno e seus homó } \\
\text { logos tóxicos }\end{array}$ & $\begin{array}{l}\text {-Ulceração ou Necrose do Septo Nasal } \\
\text { (J34.0) } \\
\text {-Bronquiolite Obliterante Crônica, Enfisema } \\
\text { Crônico Difuso ou Fibrose Pulmonar Crô- } \\
\text { nica (J68.4) } \\
\text {-Estomatite Ulcerativa Crônica (K12.1) } \\
\text {-Gastroenterite e Colites tóxicas (K52.-) } \\
\text {-Hipertensão Portal (K76.6) } \\
\text {-Dermatite de Contatopor Irritantes (L24.-) } \\
\text {-Outras formas de hiperpigmentação pela } \\
\text { melanina: “Melanodermia” (L81.4) } \\
\text {-Leucodermia, não classificada em outra } \\
\text { parte (Inclui "Vitiligo Ocupacional”) } \\
\text { (L81.5) } \\
\text {-Ceratose Palmar e Plantar Adquirida } \\
\text { (L85.1) } \\
\text {-Efeitos Tóxicos Agudos (T57.0) } \\
\text {-Neoplasia maligna do estômago (C16.-) } \\
\text {-Neoplasia maligna da laringe (C32.-) } \\
\text {-Neoplasia maligna dos brônquios e do } \\
\text { pulmão (C34.-) } \\
\text {-Mesotelioma da pleura (C45.0) } \\
\text {-Mesotelioma do peritônio (C45.1) } \\
\text {-Mesotelioma do pericárdio (C45.2) } \\
\text {-Placas epicárdicas ou pericárdicas (134.8) } \\
\text {-Asbestose (J60.-) } \\
\text {-Derrame Pleural (J90.-) } \\
\text {-Placas Pleurais (J92.-) } \\
\text {-Leucemias (C91-C95.-) } \\
\text {-Síndromes Mielodisplásicas (D46.-) } \\
\text {-Anemia Aplástica devido a outros agentes } \\
\text { externos (D61.2) } \\
\text {-Hipoplasia Medular (D61.9) } \\
\text {-Púrpura e outras manifestações } \\
\text { hemorrágicas (D69.-) } \\
\text {-Agranulocitose (Neutropenia tóxica) } \\
\text { (D70) } \\
\text {-Outros transtornos especificados dos } \\
\text { glóbulos brancos: Leucocitose, Reação } \\
\text { Leucemóide (D72.8) } \\
\text {-Outros transtornos mentais decorrentes de } \\
\text { lesão e disfunção cerebrais e de doença fí- } \\
\text { sica (F06.-) (Tolueno e outros solventes aro- } \\
\text { máticos neurotóxicos) } \\
\text {-Transtornos de personalidade e de com- } \\
\text { portamento decorrentes de doença, lesãoe } \\
\text { de disfunção de personalidade (F07.-) } \\
\text { (Tolueno e outros solventes aromáticos } \\
\text { neurotóxicos) } \\
\text {-Transtorno Mental Orgânico ou Sintomá- } \\
\text { tico não especificado (F09.-) (Tolueno e } \\
\text { outros solventes aromáticos neurotóxicos) } \\
\text {-Episódios depressivos (F32.-) (Tolueno e } \\
\text { outros solventes aromáticos neurotóxicos) } \\
\text {-Neurastenia (Inclui “Síndrome de Fadiga”) } \\
\text { (F48.0) (Tolueno e outros solventes aro- } \\
\text { máticos neurotóxicos) } \\
\text {-Encefalopatia Tóxica Crônica (G92.2) } \\
\text {-Hipoacusia Ototóxica (H91.0) (Tolueno e } \\
\text { Xileno) } \\
\end{array}$ & $\begin{array}{l}\text { 6) Cádmio ou seus com- } \\
\text { postos }\end{array}$ & 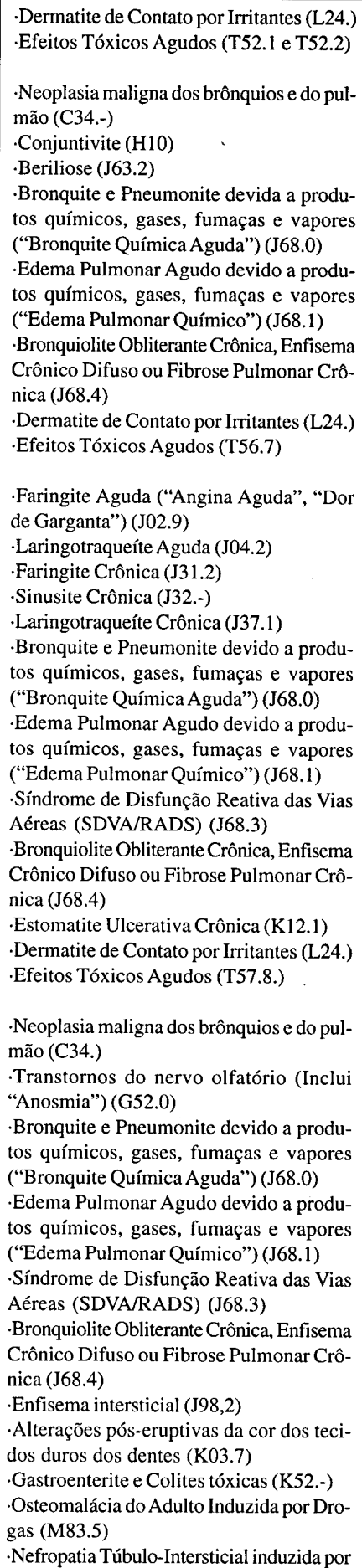 \\
\hline
\end{tabular}


metais pesados (N14.3)

-Efeitos Tóxicos Agudos (T56.3)

7) Carbonetos metálicos ·Outras Rinites Alérgicas (J30.3)

de Tungstênio sinterizados -Asma (J45.-)

-Pneumoconiose devido a outras poeiras inorgânicas especificadas (J63.8)

8) Chumbo ou seus com- Outras anemias devido a transtornos postos tóxicos

\section{enzimáticos (D55.8)}

-Anemia Sideroblástica secundária a toxinas (D64.2)

·Hipotireoidismo devido a substâncias exógenas (E03.-)

- Outros transtornos mentais decorrentes de lesão e disfunção cerebrais e de doença física (F06.-)

-Polineuropatia devido a outras agentes tóxicos (G52.2)

-Encefalopatia Tóxica Aguda (G92.1)

-Encefalopatia Tóxica Crônica (G92.2)

-Hipertensão Arterial (I10.-)

-Arritmias Cardíacas (149.-)

“Cólica da Chumbo" (K59.8)

-Gota Induzida pelo Chumbo (M10.1)

- Nefropatia Túbulo-Intersticial induzida por

metais pesados (N14.3)

-Insuficiência Renal Crônica (N17)

-Infertilidade Masculina (N46)

-Efeitos Tóxicos Agudos(T56.0)

9) Cloro $\quad$ Rinite Crônica (J31.0)

- Outras Doenças Pulmonares Obstrutivas Crônicas (Inclui "Asma Obstrutiva", "Bronquite Crônica", "Bronquite Obstrutiva Crônica") (J44.-)

Bronquite e Pneumonite devido a produtos químicos, gases, fumaças e vapores ("Bronquite Química Aguda") (J68.0)

Edema Pulmonar Agudo devido a produtos químicos, gases, fumaças e vapores ("Edema Pulmonar Químico") (J68.1) -Síndrome de Disfunção Reativa das Vias Aéreas (SDVA/RADS) (J68.3)

-Bronquiolite Obliterante Crônica, Enfisema Crônico Difuso ou Fibrose Pulmonar Crônica (J68.4)

-Efeitos Tóxịcos Agudos (T59.4)

10) Cromo ou seus com- -Neoplasia maligna dos brônquios e do pulpostos tóxicos mão (C34.-)

Outras Rinites Alérgicas (J30.3)

Rinite Crônica (J31.0)

Ulceração ou Necrose do Septo Nsal (J34.0)

Asma (J45.-)

"Dermatoses Pápulo-Pustulosas e suas complicações infecciosas" (L08.9)

-Dermatite Alérgica de Contato (L23.-)

Dermatite de Contato por Irritantes (L24.)

-Úlcera Crônica da Pele, não classificada em outra parte (L98.4)
·Efeitos Tóxicos Agudos (T56.2)

11) Flúor ous seus com- . postos tóxicos

Conjuntivite (H10)

-Rinite Crônica (J31.0)

-Bronquite e Pneumonite devido a produtos químicos, gases, fumaças e vapores ("Bronquite Química Aguda") (J68.0) -Edema Pulmonar Agudo devido a produtos químicos, gases, fumaças e vapores ("Edema Pulmonar Químico") (J68.1) -Bronquiolite Obliterante Crônica, Enfisema Crônico Difuso ou Fibrose Pulmonar Crônica (J68.4)

-Erosão Dentária (K03.2)

- Dermatite de Contato por Irritantes (L24.)

-Fluorose do Esqueleto (M85.1)

-Intoxicação Aguda (T59.5)

12)Fósforo ou seus com- Polineuropatia devida a outras agentes tópostos tóxicos $\quad$ xicos (G52.2)

-Arritmias cardíacas (I49.-) (Agrotóxicos organofosforados e carbamatos) -Dermatite Alérgica de Contato (L23.-)

- Dermatite de Contato por Irritantes (L24.)

-Osteomalácia do Adulto Induzida por Drogas (M83.5)

- Osteonecrose (M87.-): Osteonecrose Devida a Drogas (M87.1); Outras Osteonecroses Secundárias (M87.3)

-Intoxicação Aguda (T57.1) (Intoxicação Aguda por Agrotóxicos Organofosforados:T60.0)

13) Hidrocarbonetos Angiossarcoma do fígado (C22.3)

alifáticos ou aromáticos Neoplasia maligna do pâncreas (C25.-)

(seus derivados haloge- Neoplasia maligna dos brônquios e do pul-

nados tóxicos) mão (C34.-)

Púrpura e outras manifestações hemorrágicas (D69.-)

Hipotireoidismo devido a substâncias exógenas (E03.-)

Outras porfirias (E80.2)

Delirium, não sobreposto à demência, como descrita (F05.0) (Brometo de Metila)

Outros transtornos mentais decorrentes de lesão e disfunção cerebrais e de doença física (F06.-)

Transtornos de personalidade e de comportamento decorrentes de doença, lesão e de disfunção de personalidade (F07.-)

Transtorno Mental Orgânico ou Sintomático não especificado (F09.-)

Episódios Depressivos (F32.-)

Neurastenia (Inclui "Síndrome de Fadiga") (F48.0)

Outras formas especificadas de tremor (G25.2)

Transtorno extrapiramidal do movimento não especificado (G25.9)

Transtornos do nervo trigêmio (G50.-)

Polineuropatia devido a outros agentes tóxicos (G52.2) (n-Hexano)

Encefalopatia Tóxica Aguda (G92.1) 


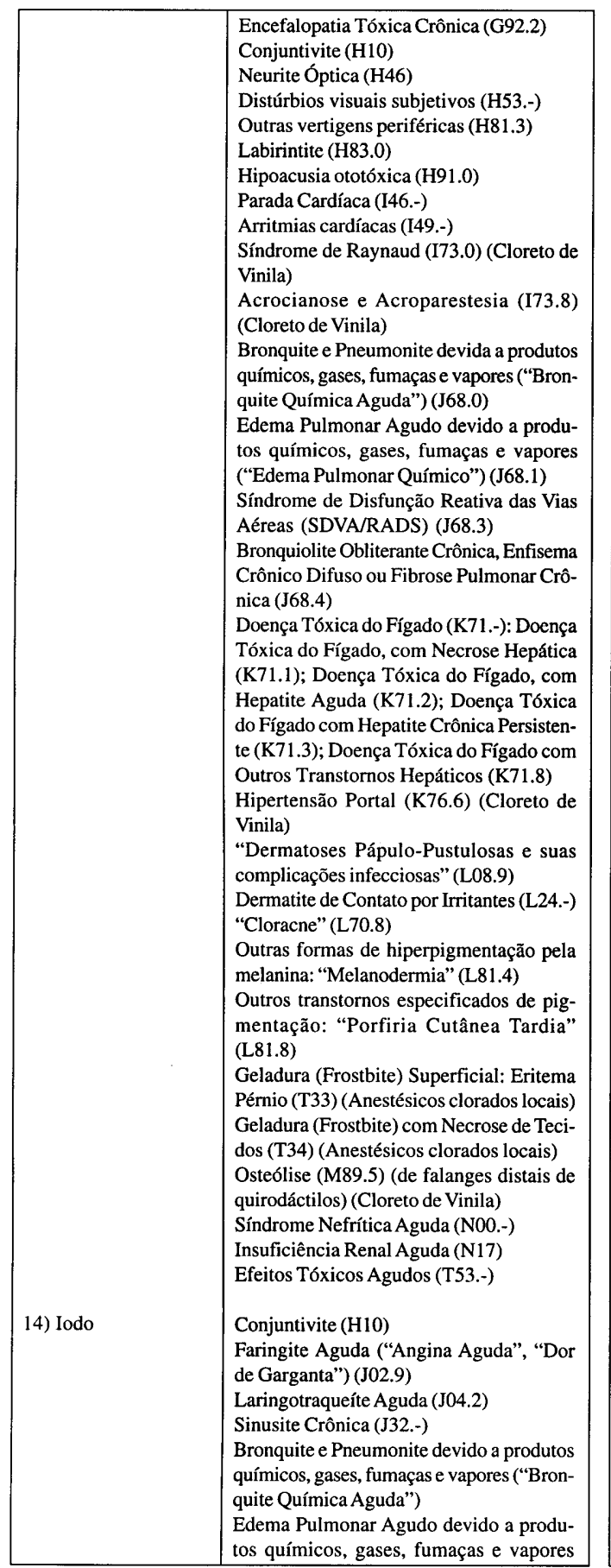

\begin{tabular}{|c|c|}
\hline & $\begin{array}{l}\text { ("Edema Pulmonar Químico") (J68.1) } \\
\text { Síndrome de Disfunção Reativa das Vias } \\
\text { Aéreas (SDVA/RADS) (J68.3) } \\
\text { Bronquiolite Obliterante Crônica, Enfisema } \\
\text { Crônico Difuso ou Fibrose Pulmonar Crô-- } \\
\text { nica (J68.4) Dermatite Alérgica de Con- } \\
\text { tato (L23.-) } \\
\text { Efeitos Tóxicos Agudos (T57.8) }\end{array}$ \\
\hline $\begin{array}{l}\text { 15) Manganês e seus } \\
\text { compostos tóxicos }\end{array}$ & $\begin{array}{l}\text { Demência em outras doenças específicas } \\
\text { classificiadas em outros locais (F02.8) } \\
\text { Outros transtornos mentais decorrentes de } \\
\text { lesão e disfunção cerebrais e de doença fí- } \\
\text { sica (F06.-) } \\
\text { Transtornos de personalidade e de compor- } \\
\text { tamento decorrentes de doença, lesão e de } \\
\text { disfunção de personalidade (F07.-) } \\
\text { Transtorno Mental Orgânico ou Sintomáti- } \\
\text { co não especificado (F09.-) } \\
\text { Episódios Depressivos (F32.-) } \\
\text { Neurastenia (Inclui "Síndrome de Fadiga") } \\
\text { (F48.0) } \\
\text { Parkisonismo Secundário (G21.2) } \\
\text { Inflamação Coriorretiniana (H30) } \\
\text { Bronquite e Pneumonite devido a produtos } \\
\text { qứmicos, gases, fumaças e vapores ("Bron- } \\
\text { quite Quúmica Aguda") (J68.0) } \\
\text { Bronquiolite Obliterante Crônica, Enfisema } \\
\text { Crônico Difuso ou Fibrose Pulmonar Crô-- } \\
\text { nica (J68.4) } \\
\text { Efeitos Tóxicos Agudos (T57.2) }\end{array}$ \\
\hline $\begin{array}{l}\text { 16) Mercúrio e seus } \\
\text { compostos tóxicos }\end{array}$ & $\begin{array}{l}\text { Outros transtornos mentais decorrentes de } \\
\text { lesão e disfunção cerebrais e de doença fi- } \\
\text { sica (F06.-) } \\
\text { Transtornos de personalidade e de compor- } \\
\text { tamento decorrentes de doença, lesão e de } \\
\text { disfunção de personalidade (F07.-) } \\
\text { Transtorno Mental Orgânico ou Sintomáti- } \\
\text { co não especificado (F09.-) } \\
\text { Epiśdios Depressivos (F32.-) } \\
\text { Neurastenia (Inclui “Síndrome de Fadiga”) } \\
\text { (F48.0) } \\
\text { Ataxia Cerebelosa (G1 1.1) } \\
\text { Outras formas especificadas de tremor } \\
\text { (G25.2) } \\
\text { Transtorno extrapiramidal do movimento } \\
\text { não especificado (G25.9) } \\
\text { Encefalopatia Tóxica Aguda (G92.1) } \\
\text { Encefalopatia Tóxica Crônica (G92.2) } \\
\text { Arritmias cardíacas) (I49.-) } \\
\text { Gengivite Crônica (K05.1) } \\
\text { Estomatite Ulcerativa Crônica (K12.1) } \\
\text { Dermatite Alérgica de Contato (L23.-) } \\
\text { Doença Glomerular Crônica (N03.-) } \\
\text { Nefropatia Túbulo-Intersticial induzida por } \\
\text { metais pesados (N14.3) } \\
\text { Efeitos Tóxicos Agudos (T57.1) }\end{array}$ \\
\hline $\begin{array}{l}\text { 17) Substâncias asfixian- } \\
\text { tes: Monóxido de Carbo- } \\
\text { no, Cianeto de Hidrogênio }\end{array}$ & $\begin{array}{l}\text { Demência em outras doenças específicas } \\
\text { classificadas em outros locais (F02.8) } \\
\text { Transtornos do nervo olfatório (Inclui }\end{array}$ \\
\hline
\end{tabular}


ou seus derivados tóxi$\cos$, Sulfeto de Hidrogênio (Ácido Sulfídrico)
“Anosmia") (G52.0) ( $\left.\mathrm{H}_{2} \mathrm{~S}\right)$

Encefalopatia Tóxica Crốnica (G92.2) (Se

qüela)

Conjuntivite (H10) (H/S)

Queratite e Queratoconjuntivite (H16)

Angina Pectoris (120.-) (CO)

Infarto Agudo do Miocárdio (I21.-) (CO)

Parada Cardíaca (I46.-) (CO)

Arritmias cardíacas (I49.-) (CO)

Bronquite e Pneumonite devido a produtos

químicos, gases, fumaças e vapores ("Bronquite Química Aguda") (HCN)

Edema Pulmonar Agudo devido a produtos químicos, gases, fumaças e vapores ("Edema Pulmonar Químico") (J68.1) ( $\mathrm{HCN})$

Síndrome de Disfunção Reativa das Vias Aéreas (SDVA/RADS) (J68.3) (HCN) Bronquiolite Obliterante Crônica, Enfisema Crônico Difuso ou Fibrose Pulmonar Crônica (J68.4) (HCN; $\left.\mathrm{H}_{2} \mathrm{~S}\right)$

Efeitos Tóxicos Agudos (T57.3; T58; T59.6)

Neoplasia maligna dos brônquios e do pulmão (C34.-)

Cor Pulmonale (I27.9)

Outras Doenças Pulmonares Obstrutivas Crônicas (Inclui "Asma Obstrutiva", "Bronquite Crônica","Bronquite Obstrutiva Crônica") (J44.-)

Silicose (J62.8)

Pneumoconiose associada com Tuberculose ("Sílico-Tuberculose") (J63.8)

Síndrome de Caplan (J99.1; M05.3)

19) Sulfeto de Carbono Demência em outras doenças específicas ou Dissulfeto de Carbono classificadas em outros locais (F02.8)

Outros transtornos mentais decorrentes de lesão e disfunção cerebrais e de doença física (F06.-)

Transtornos de personalidade e de comportamento decorrentes de doença, lesão e de disfunção de personalidade (F07.-)

Transtorno Mental Orgânico ou Sintomático não especificado (F09.-)

Episódios Depressivos (F32.-)

Neurastenia (Inclui "Síndrome de Fadiga") (F48.0)

Polineuropatia devido a outros agentes tóxicos (G52.2)

Encefalopatia Tóxica Crônica (G92.2)

Neurite Óptica (H46)

Angina Pectoris (120.-)

Infarto Agudo do Miocárdio (I21.-)

Ateroesclerose (I70.-) e Doença

Ateroesclerótica do Coração (125.1)

Efeitos Tóxicos Agudos (T52.8)

20) Alcatrão, Breu, Be- Neoplasia maligna dos brônquios e do pultume, Hulha Mineral, mão (C34.-)

Parafina e produtos ou Outras neoplasias malignas da pele (C44.) resíduos dessas substâncias, causadores de epiteliomas primitivos da pele

Neoplasia maligna da bexiga (C67.-) Dermatite Alérgica de Contato (L23.-)

Outras formas de hiperpigmentação pela melanina: "Melanodermia" (L81.4)

21) Ruído e afeç̧ão au- Perda da Audição Provocada pelo Ruído ditiva

(H83.3)

Outras percep̧ões auditivas anormais: Alteração Temporária do Limiar Auditivo, Comprometimento da Discriminação Auditiva e Hiperacusia (H93.2)

Hipertensão Arterial (I10.-)

Ruptura Traumática do Tímpano (pelo ruído) $(\mathrm{S} 09.2)$

22) Vibrações (afecções Síndrome de Raynaud (173.0)

dos músculos, tendões, Acrocianose e Acroparestesia (I73.8)

ossos, articulações, vasos Outros transtornos articulares não classifi-

sangüíneos periféricos ou cados em outra parte: Dor Articular (M25.5)

dos nervos periféricos) Síndrome Cervicobraquial (M53.1)

Fibromatose da Fascia Palmar: "Contratura ou Moléstia de Dupuytren" (M72.0)

Lesões do Ombro (M75.-): Capsulite Adesiva do Ombro (Ombro Congelado, Periartrite do Ombro) (M75.0); Síndrome do Manguito Rotatório ou Síndrome do Supraespinhoso (M75.1); Tendinite Bicipital (M75.2); Tendinite Calcificante do Ombro (M75.3); Bursite do Ombro (M75.5); Outras Lesões do Ombro(M75.8); Lesões do Ombro, não especificadas (M75.9)

Outras entesopatias (M77.-): Epicondilite Medial (M77.0); Epicondilite lateral ("Cotovelo de Tenista"); Mialgia (M79.1) Outros transtornos especificados dos tecidos moles (M79.8)

Osteonecrose (M87.-): Osteonecrose Devida a Drogas (M87.1); Outras Osteonecroses Secundárias (M87.3)

Doença de Kienböck do Adulto (Osteocondrose do Adulto do Semilunar do Carpo) (M93.1) e outras Osteocondro-patia especificadas (M93.8)

23) Ar Comprimido

Otite Média não supurativa (H65.9)

Perfuração da Membrama do Tímpano (H72 ou S09.2)

Labirintite (H83.0)

Otalgia e Secreção Auditiva (H92.-

Outros transtornos especificados do ouvido (H93.8)

Osteonecrose no "Mal dos Caixões" (M90.3)

Otite Barotraumática (T70.0)

Sinusite Barotraumática (IT70.1)

"Mal dos Caixões" (Doença da Descompressão) (T70.4)

Síndrome devida ao deslocamento de ar de uma explosão (T70.8)

24) Radiações Ionizantes Neoplasia maligna da cavidade nasal e dos 


\begin{tabular}{|c|c|}
\hline $\begin{array}{l}\text { 25) Microorganismos e } \\
\text { parasitas infecciosos vivos } \\
\text { e seus produtos tóxicos } \\
\text { (Exposiçãoocupacional aq } \\
\text { agente e/ou transmissor do } \\
\text { doença, em profissões e } \\
\text { ou condições de trabalho } \\
\text { especificadas) }\end{array}$ & 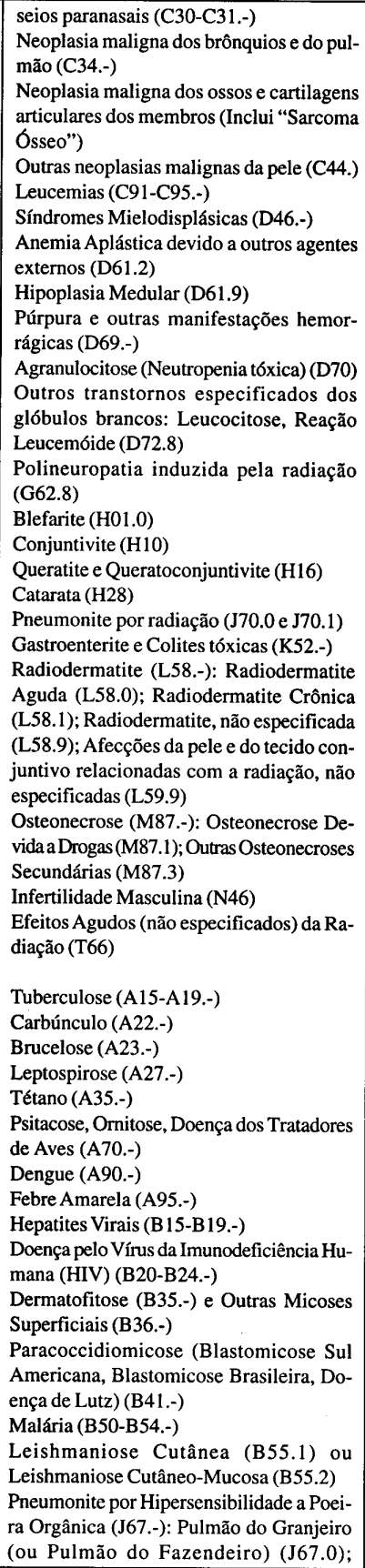 \\
\hline
\end{tabular}

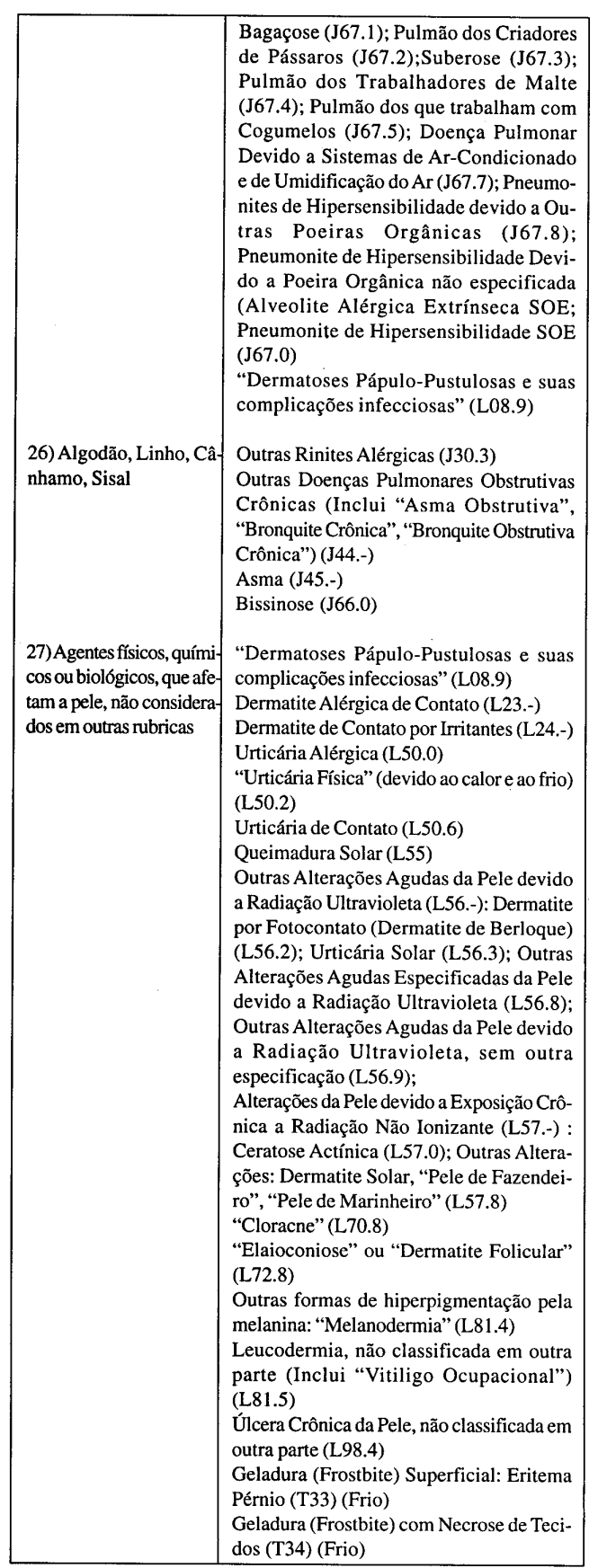




\begin{tabular}{|c|c|c|c|}
\hline \multicolumn{2}{|c|}{$\begin{array}{l}\text { DOENÇAS INFECCIOSAS E PARASITÁRIAS RELACIONADAS COM } 0 \text { TRABAHO } \\
\text { (Grupo I do (ID-10) }\end{array}$} & \multirow{2}{*}{ Febre Amarela (A95.-) } & \multirow{2}{*}{$\begin{array}{l}\text { gue, principalmente em atividades em zo- } \\
\text { nas endêmicas, em trabalhos de saúde pú- } \\
\text { blica, e em trabalhos de laboratórios de pes- } \\
\text { quisa, entre outros. (Z57.8) (Quadro 25) }\end{array}$} \\
\hline Doenças & $\begin{array}{c}\text { Agentes etiológicos ou fatores de risco } \\
\text { de natureza ocupacional }\end{array}$ & & \\
\hline Tuberculose (A15-A19.-) & $\begin{array}{l}\text { Exposição ocupacional ao Mycobacterium } \\
\text { tuberculosis (Bacilo de Koch) ou } \\
\text { Mycobacterium bovis, em atividades em } \\
\text { laboratórios de biologia, e atividades reali- } \\
\text { zadas por pessoal de saúde, que propiciam } \\
\text { contato direto com produtos contaminados } \\
\text { ou com doentes cujos exames bacteriológi- } \\
\text { cos são positivos (Z57.8) (Quadro 25) } \\
\text { Hipersuscetibilidade do trabalhador expos- } \\
\text { to a poeiras de sílica (Sílico-tuberculose) } \\
\text { (J65.-) } \\
\text { Zoonose causada pela exposição ocupacional } \\
\text { ao Bacillus anthracis, em atividades susce- } \\
\text { tíveis de colocar os trabalhadores em con- } \\
\text { tato direto com animais infectados ou com } \\
\text { cadáveres desses animais; trabalhos } \\
\text { artesanais ou industriais com pelos, pele, } \\
\text { couro ou lã. (Z57.8) (Quadro 25) }\end{array}$ & $\begin{array}{l}\text { Hepatites Virais (B15- } \\
\text { B19.) }\end{array}$ & $\begin{array}{l}\text { Exposiçao ocupacional ao mosquito (Aedes } \\
\text { aegypti), transmissor do arbovírus da Fe- } \\
\text { bre Amarela, principalmente em atividades } \\
\text { em zonas endêmicas, em trabalhos de saú- } \\
\text { de pública, e em trabalhos de laboratórios } \\
\text { de pesquisa, entre outros. (Z57.8) (Quadro } \\
\text { 25) } \\
\text { Exposição ocupacional ao Vírus da Hepati- } \\
\text { te A (HAV); Vírus da Hepatite B (HBV); } \\
\text { Vírus da Hepatite C (HCV); Vírus da He- } \\
\text { patite D(HDV); Vírus da Hepatite E(HEV), } \\
\text { em trabalhos envolvendo manipulação, } \\
\text { acondicionamento ou emprego de sangue } \\
\text { humano ou de seus derivados; trabalho com } \\
\text { "águas usadas"e esgotos; trabalhos em con- } \\
\text { tato com materiais provenientes de doentes } \\
\text { ou objetos contaminado por eles. (Z57.8) } \\
\text { (Quadro 25) }\end{array}$ \\
\hline Brucelose (A23.-) & $\begin{array}{l}\text { Zoonose causada pela exposição ocupacional } \\
\text { a Brucella melitensis, B. abortus, B. suis, } \\
\text { B. canis, etc., em atividades em abate- } \\
\text { douros, frigoríficos, manipulação de pro- } \\
\text { dutos de carne; ordenha e fabricação de la- } \\
\text { ticínios e atividades assemelhadas. (Z57.8) } \\
\text { (Quadro 25) }\end{array}$ & $\begin{array}{l}\text { Doença pelo Vírus da } \\
\text { Imunodeficiência Huma- } \\
\text { na (HIV) (B20-B24.-) }\end{array}$ & $\begin{array}{l}\text { Exposição ocupacional ao Vírus da Imuno- } \\
\text { deficiência Humana (HIV), principalmente } \\
\text { em trabalhadores da saúde, em decorrência } \\
\text { de acidentes perfurocortantes com agulhas } \\
\text { ou material cirúrgico contaminado, e na ma- } \\
\text { nipulação, acondicionamento ou emprego } \\
\text { de sangue ou de seus derivados, e contato } \\
\text { com materiais provenientes de pacientes } \\
\text { infectados. (Z57.8) (Quadro } 25 \text { ) }\end{array}$ \\
\hline \multirow[t]{2}{*}{ Leptospirose (A27.-) } & $\begin{array}{l}\text { Exposição ocupacional a Leptospira ictero- } \\
\text { haemorrhagiae (e outras especies), em tra- } \\
\text { balhos expondo ao contato direto com águas } \\
\text { sujas, ou efetuado em locais suscetíveis de } \\
\text { serem sujos por dejetos de animais porta- } \\
\text { dores de germes; trabalhos efetuados den- } \\
\text { tro de minas, túneis, galerias, esgotos em } \\
\text { locais subterrâneos; trabalhos em cursos } \\
\text { d'água; trabalhos de drenagem; contato com }\end{array}$ & $\begin{array}{l}\text { Dermatofitose (B35.-) e } \\
\text { Outras Micoses Superfi-- } \\
\text { ciais (B36.-) }\end{array}$ & $\begin{array}{l}\text { Exposição ocupacional a fungos do gênero } \\
\text { Epidermophyton, Microsporum e } \\
\text { Trichophyton, em trabalhos em condições } \\
\text { de temperatura elevada e umidade (cozinhas, } \\
\text { ginásios, piscinas) e outras situações espe- } \\
\text { cíficas de exposição ocupacional. (Z57.8) } \\
\text { (Quadro 25) }\end{array}$ \\
\hline & $\begin{array}{l}\text { roedores; trabalhos com animais domésti- } \\
\text { cos, e com gado; preparação de alimentos de } \\
\text { origem animal, de peixes, de laticínios, etc.. } \\
\text { (Z57.8) (Quadro 25) } \\
\text { Exposição ao Clostridium tetani, em circuns- } \\
\text { tâncias de acidentes do trabalho na agricul- } \\
\text { tura, na construção civil, na indústria, ou em }\end{array}$ & Candidíase (B37.-) & $\begin{array}{l}\text { Exposição ocupacional a Candida albicans, } \\
\text { Candida glabrata, etc., em trabalhos que } \\
\text { requerem longas imersões das mãos em } \\
\text { água e irritação mecânica das mãos, tais } \\
\text { como trabalhadores de limpeza, lavadeiras, } \\
\text { cozinheiras, entre outros.. (Z57.8) (Qua- } \\
\text { dro 25) }\end{array}$ \\
\hline Psitacose, Ornitose, Dó & $\begin{array}{l}\text { acidentes de trajeto (Z57.8) (Quadro 25) } \\
\text { Zoonoses causadas pela exposição } \\
\text { ocupacional a Chlamydia psittaci ou } \\
\text { Chlamydia pneumoniae, em trabalhos em } \\
\text { criadouros de aves ou pássaros, atividades }\end{array}$ & $\begin{array}{l}\text { Paracoccidioidomicose } \\
\text { (Blastomicose Sul Ame- } \\
\text { ricana, Blastomicose } \\
\text { Brasileira, Doença de } \\
\text { Lutz)(B41.-) }\end{array}$ & $\begin{array}{l}\text { Exposição ocupacional ao Paracoccidioides } \\
\text { brasiliensis, principalmente em trabalhos } \\
\text { agrícolas ou florestais e em zonas en- } \\
\text { dêmicas. (Z57.8) (Quadro 25) }\end{array}$ \\
\hline & $\begin{array}{l}\text { de Veterinária, em zoológicos, e em labora- } \\
\text { tórios biológicos, etc.(Z57.8) (Quadro 25) }\end{array}$ & Malária (B50 B54.-) & Exposição ocupacional ao Plasmodium \\
\hline $\begin{array}{l}\text { Dengue [Dengue Clássi- } \\
\text { co] (A90.-) }\end{array}$ & $\begin{array}{l}\text { Exposição ocupacional ao mosquito (Aedes } \\
\text { aegypti), transmissor do arbovírus da Den- }\end{array}$ & & $\begin{array}{l}\text { palmente em atividades de mineração, cons- } \\
\text { trução de barragens ou rodovias, em extra- }\end{array}$ \\
\hline
\end{tabular}




\begin{tabular}{|c|c|c|c|}
\hline $\begin{array}{l}\text { Leishmaniose Cutânea } \\
\text { (B55.1) ou Leishmaniose } \\
\text { Cutâneo-Mucosa (B55.2) }\end{array}$ & $\begin{array}{l}\text { ção de petróleo e outras atividades que obri- } \\
\text { gam a entrada dos trabalhadores em zonas } \\
\text { endêmicas (Z57.8) (Quadro 25) } \\
\text { Exposição ocupacional à Leishmania } \\
\text { braziliensis, principalmente em trabalhos } \\
\text { agrícolas ou florestais e em zonas } \\
\text { endêmicas, e outras situações específicas } \\
\text { de exposição ocupacional. (Z57.8) (Qua- } \\
\text { dro 25) }\end{array}$ & \multirow{3}{*}{$\begin{array}{l}\text { Neoplasia maligna dos } \\
\text { ossos e cartilagens arti- } \\
\text { culares dos membros (In- } \\
\text { clui "Sarcoma Ósseo") } \\
\text { (C40.-) }\end{array}$} & \multirow{3}{*}{$\begin{array}{l}\text {-Radiações ionizantes (W88.-;Z57.1)(Qua- } \\
\text { dro 24) } \\
\text { - Emissões de fornos de coque (X49.-; } \\
\text { Z57.5) } \\
\text { - Níquel e seus compostos (X49.-; Z57.5) } \\
\text { - Acrilonitrila (X49.-;Z57.5) } \\
\text { - Indústria do alumínio (fundições) (X49.- } \\
\text {;Z57.5) } \\
\text { - Neblinas de 6leos minerais (6leo de corte) } \\
\text { (X49.-;Z57.5) } \\
\text { - Fundições de metais (X49.-; Z57.5) } \\
\text { - Radiações ionizantes (W88.-;Z57.1)(Qua- } \\
\text { dro 24) }\end{array}$} \\
\hline \multicolumn{2}{|c|}{$\begin{array}{l}\text { NEOPLASIAS (TUMORES) RELACIONADOS COM O TRABALHO } \\
\text { (GRUPO II do CID-10) }\end{array}$} & & \\
\hline Doenças & $\begin{array}{c}\text { Agentes etiológicos ou fatores de risco } \\
\text { de natureza ocupacional }\end{array}$ & & \\
\hline $\begin{array}{l}\text { Neoplasia maligna do es- } \\
\text { tômago (C16.-) } \\
\text { Angiossarcoma do fíga- } \\
\text { do (C22.3) }\end{array}$ & $\begin{array}{l}\text { - Asbesto ou Amianto (X49.-; Z57.2) (Qua- } \\
\text { dro 2) } \\
\text { - Arsênio e seus compostos arsenicais } \\
\text { (X48.-; X49.-;Z57.5) (Quadro 1) }\end{array}$ & $\begin{array}{l}\text { Outras neoplasias malig- } \\
\text { nas da pele (C44.-) }\end{array}$ & $\begin{array}{l}\text { - Arsênio e seus compostos arsenicais } \\
\text { (X49.-; Z57.4 e Z57.5) (Quadro 1) } \\
\text { - Alcatrão, breu, betume, hulha mineral, pa- } \\
\text { rafina e produtos de resíduos dessas subs- } \\
\text { tâncias causadores de epiteliomas da pele } \\
\text { (X49.-; Z57.5) (Quadro 20) } \\
\text { - Radiações ionizantes (W88.-;Z57.1) (Qua- } \\
\text { dro 24) } \\
\text { - Radiações ultravioletas (W89; Z57.1) }\end{array}$ \\
\hline $\begin{array}{l}\text { Cloreto de Vinila (X46.-; } \\
\text { Z57.5) (Quadro 13) }\end{array}$ & $\begin{array}{l}\text { - Epicloridrina (X49.-;Z57.5) } \\
\text { - Hidrocarbonetos alifáfitos e aromáticos } \\
\text { na Indústria do Petróleo (X46.-;Z57.5) }\end{array}$ & $\begin{array}{l}\text { Mesotelioma (C45.):Me- } \\
\text { sotelioma da pleura } \\
\text { (C45.0), Mesotelioma do } \\
\text { peritónio (C45.1) e }\end{array}$ & $\begin{array}{l}\text {-Asbesto ou Amianto (X49.-; Z57.2) (Qua- } \\
\text { dro 2) }\end{array}$ \\
\hline $\begin{array}{l}\text { Neoplasia maligna daca- } \\
\text { vidade nasal e dos seios } \\
\text { paranasais (C30-C31.-) }\end{array}$ & $\begin{array}{l}\text { - Radiaçōes ionizantes (W88.-; Z57.1)(Qua- } \\
\text { dro 24) } \\
\text { - Níquel e seus compostos (X49.-; Z57.5) }\end{array}$ & $\begin{array}{l}\text { Mesotelioma do peri- } \\
\text { cárdio (C45.2) }\end{array}$ & 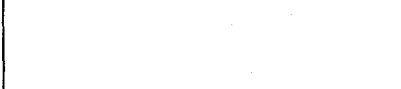 \\
\hline & $\begin{array}{l}\text { - Poeiras de madeira e outras poeiras orgâ- } \\
\text { nicas da indústria do mobiliário (X49.-; } \\
\text { Z57.2) } \\
\text { - Poeiras da indústria do couro (X49.-; } \\
\text { Z57.2) } \\
\text { - Poeiras orgânicas (na indústria têxtil e em } \\
\text { padarias) (X49.-; Z57.2) } \\
\text { 60-Indústria do petróleo (X46.-; Z57.5) }\end{array}$ & $\begin{array}{l}\text { Neoplasia maligna da be- } \\
\text { xiga (C67.-) }\end{array}$ & $\begin{array}{l}\text { - Alcatrão, breu, betume, hulha mineral, pa- } \\
\text { rafina e produtos de resíduos dessas subs- } \\
\text { tâncias (X49.-; Z57.5 (Quadro 20) } \\
\text { - Aminas aromáticas e seus derivados (Beta- } \\
\text { naftilamina, 2-cloroanilina, benzidina, o- } \\
\text { toluidina, 4-cloro-orto-toluidina }(\mathrm{X} 49 .-; \mathrm{Z57.5}) \\
\text {-Emissões de fornos de coque (X49.-;Z57.5) }\end{array}$ \\
\hline \multirow{5}{*}{$\begin{array}{l}\text { Neoplasia maligna da la- } \\
\text { ringe (C32.-) } \\
\text { Neoplasia maligna dos } \\
\text { brônquios e do pulmão } \\
\text { (C34.-) }\end{array}$} & \multirow{5}{*}{$\begin{array}{l}\text { - Asbesto ou Amianto (Z57.2) (Quadro 2) } \\
\text { - Arsênio e seus compostos arsenicais } \\
\text { (X48.-; X49.-; Z57.4 e Z57.5) (Quadro 1) } \\
\text { - Asbesto ou Amianto (X49.-; Z57.2) (Qua- } \\
\text { dro 2) } \\
\text { - Berílio (X49.-; Z57.5) (Quadro 4) } \\
\text { - Cádmio ou seus compostos (X49.-; } \\
\text { Z57.5)(Quadro 6) } \\
\text { - Cromo e seus compostos tóxicos (X49.-; } \\
\text { Z57.5) (Quadro 10) } \\
\text {-Cloreto deVinila (X46.-;Z57.5) (Quadro 13) } \\
\text {-Clorometil éteres (X49.-;Z57.5) (Quadro 13) } \\
\text { - Sílica-livre (Z57.2) (Quadro 18) } \\
\text { - Alcatrão, breu, betume, hulha mineral,pa- } \\
\text { rafina e produtos de resíduos dessas subs- } \\
\text { tâncias (X49.-;Z57.5) (Quadro 20) }\end{array}$} & Leucemias (C91-C95.-) & $\begin{array}{l}\text { - Benzeno (X46.-; Z57.5) (Quadro 3) } \\
\text { - Radiaçöes ionizantes (W88.-;Z57.1) (Qua- } \\
\text { dro 24) } \\
\text { - Oxido de etileno (X49.-; Z57.5) }\end{array}$ \\
\hline & & & $\begin{array}{l}\text { - Agentes antineoplásicos (X49.-; Z57.5) } \\
\text { - Campos eletromagnéticos (W90.-;Z57.5) } \\
\text { - Agrotóxicos clorados (Clordane e } \\
\text { Heptaclor) (X48.-;Z57.4) }\end{array}$ \\
\hline & & \multicolumn{2}{|c|}{$\begin{array}{l}\text { DOENÇAS DO SANGUE E DOS ÓRGÃOS HEMATOPOÉTICOS RELACIONADAS } \\
\text { COM } 0 \text { TRABALHO (Grupo III do (ID-10) }\end{array}$} \\
\hline & & Doenças & $\begin{array}{l}\text { Agentes etiológicos ou fatores de risco } \\
\text { de natureza ocupacional }\end{array}$ \\
\hline & & $\begin{array}{l}\text { Síndromes Mielodisplá- } \\
\text { sicas (D46.-) }\end{array}$ & $\begin{array}{l}\text { - Benzeno (X46,-; Z57.5) (Quadro 3) } \\
\text { - Radiações ionizantes (W88.-;Z57.1) (Qua- } \\
\text { dro 24) } \\
\text { - Chumbo ou seus compostos tóxicos }\end{array}$ \\
\hline
\end{tabular}


Outras anemias devidas (X49.-; Z57.5) (Quadro 8) a transtornos enzimáticos

(D55.8)

Anemia Hemolítica ad- - Derivados nitrados e aminados do quirida (D59.2) Benzeno (X46.-; Z57.5)

Anemia Aplástica devida - Benzeno (X46.-; Z57.5) (Quadro 3) a outros agentes externos - Radiações ionizantes (W88.-) (Quadro 24) (D61.2)

Anemia Aplástica não es- - Benzeno (X46.-; Z57.5)(Quadro 3) pecificada, Anemia hipo- - Radiações ionizantes (W88.-;Z57.1) (Quaplástica SOE, Hipoplasia dro 24) medular (D61.9)

Anemia Sideroblástica - Chumbo ou seus compostos tóxicos secundária a toxinas (In- (X46.-; Z57.5) (Quadro 8) clui "Anemia Hipocrô-

mica, Microcítica, com

Reticulocitose") (D64.2)

Púrpura e outras mani- - Benzeno (X46.-; Z57.5) (Quadro 3)

festações hemorrágicas - Cloreto de Vinila (X46.-)(Quadro 13)

(D69.-) -Radiações ionizantes (W88.-;Z57.1) (Quadro 24)

Agranulocitose (Neutro- - Benzeno (X46.-; Z57.5) (Quadro 3) penia tóxica) (D70) - Radiações ionizantes (W88.-;Z57.1) (Quadro 24)

- Derivados do Fenol, Pentaclorofenol, Hidroxibenzonitrilo (X49.-; XZ57.5)

Outros transtornos espe- - Benzeno (X46.-; Z57.5)(Quadro 3) cificados dos glóbulos -Radiações ionizantes (W88.-;Z57.1) (Quabrancos: leucocitose, re- dro 24) ação leucemóide (D72.8)

Metahemoglobinemia - Aminas aromáticas e seus derivados (D74.-) (X49.-; Z57.5)

DOENÇAS ENDÓCRINAS, NUTRICIONAIS E METABÓLICAS RELACIONADAS COM O TRABALHO (Grupo IV do CID-10)

\section{Doenças Agentes etiológicos ou fatores de risco} de natureza ocupacional

Hipotireoidismo devido a - Chumbo ou seus compostos tóxicos substâncias exógenas (X49.-; Z57.5) (Quadro 8) (E03.-) - Hidrocarbonetos halogenados (Clorobenzeno e seus derivados) (X46.-; Z57.5) (Quadro 13)

- Tiuracil (X49.-;Z57.5)

- Tiocinatos (X49.-;Z57.5

- Tiuréia (X49.-;Z57.5)

Outras Porfirias (E.80.2) Clorobenzeno e seus derivados (X46.-; Z57.4 e Z57.5) (Quadro 13)
TRANSTORNOS MENTAIS E DO COMPORTAMENTO RELACIONADOS COM O TRABALHO (Grupo V do CID-10)

\begin{tabular}{|c|c|}
\hline Doenças & $\begin{array}{c}\text { Agentes etiológicos ou fatores de risco } \\
\text { de natureza ocupacional }\end{array}$ \\
\hline $\begin{array}{l}\text { Demência em outras } \\
\text { doenças específicas } \\
\text { classificadas em outros } \\
\text { locais (F02.8) }\end{array}$ & $\begin{array}{l}\text {-Manganês (X49.-; Z57.5) (Quadro 15) } \\
\text {-Substâncias asfixiantes: CO, } \mathrm{H}_{2} \mathrm{~S} \text {, etc. (se- } \\
\text { qüela) (X47.-; Z57.5) (Quadro 17) } \\
\text {-Sulfeto de Carbono (X49.-; Z57.5) (Qua- } \\
\text { dro 19) }\end{array}$ \\
\hline $\begin{array}{l}\text { Delirium, não sobre- } \\
\text { posto a demência, como } \\
\text { descrita (F05.0) }\end{array}$ & $\begin{array}{l}\text { - Brometo de Metila (X46.-;Z57.4 eZ57.5) } \\
\text { (Quadro 13) } \\
\text { - Sulfeto de Carbono (X49.-; Z57.5) (Qua- } \\
\text { dro 19) }\end{array}$ \\
\hline $\begin{array}{l}\text { Outros transtornos men- } \\
\text { tais decorrentes de le- } \\
\text { são e disfunção cere- } \\
\text { brais e de doença física } \\
\text { (F06.-): Transtorno } \\
\text { Cognitivo Leve (F06.7) }\end{array}$ & $\begin{array}{l}\text { - Tolueno e outros solventes aromáticos } \\
\text { neurotóxicos (X46.-; Z57.5) (Quadro 3) } \\
\text { - Chumbo ou seus compostos tóxicos } \\
\text { (X49.-; Z57.5) (Quadro 8) } \\
\text { - Tricloroetileno, Tetracloroetileno, Triclo- } \\
\text { roetano e outros solventes orgânicos halo- } \\
\text { genados neurotóxicos (X46.-;Z57.5) (Qua- } \\
\text { dro 13) } \\
\text { - Brometo de Metila (X46.-;Z57.4 e Z57.5) } \\
\text { (Quadro 13) } \\
\text { - Manganês e seus compostos tóxicos } \\
\text { (X49.-; Z57.5) (Quadro 15) } \\
\text { - Mercúrio e seus compostos tóxicos (X49.- } \\
\text {;Z57.4 e Z57.5) (Quadro 16) } \\
\text { - Sulfeto de Carbono (X49.-;Z57.5) (Qua- } \\
\text { dro 19) } \\
\text { - Outros solventes orgânicos neurotóxicos } \\
\text { (X46.-; X49.-; Z57.5) }\end{array}$ \\
\hline $\begin{array}{l}\text { Transtornos de perso- } \\
\text { nalidade e de compor- } \\
\text { tamento decorrentes de } \\
\text { doença, lesão e de } \\
\text { disfunção de persona- } \\
\text { lidade (F07.-): Trans- } \\
\text { torno Orgânico de Per- } \\
\text { sonalidade (F07.0); } \\
\text { Outros transtornos de } \\
\text { personalidade e de } \\
\text { comportamento decor- } \\
\text { rentes de doença, lesão } \\
\text { ou disfunção cerebral } \\
\text { (F07.8) }\end{array}$ & $\begin{array}{l}\text { - Tolueno e outros solventes aromáticos } \\
\text { neurotóxicos (X46.-; Z57.5) (Quadro 3) } \\
\text { - Tricloroetileno, Tetracloroetileno, Triclo- } \\
\text { roetano e outros solventes orgânicos halo- } \\
\text { genados neurotóxicos (X46.-;Z57.5) (Qua- } \\
\text { dro 13) } \\
\text { - Brometo de Metila (X46.-;Z57.4 e Z57.5) } \\
\text { (Quadro 13) } \\
\text { - Manganês e seus compostos tóxicos } \\
\text { (X49.--; Z57.5) (Quadro 15) } \\
\text { - Mercúrio e seus compostos tóxicos (X49.- } \\
\text {; Z57.4 e Z57.5) (Quadro 16) } \\
\text { - Sulfeto de Carbono (X49.-;Z57.5) (Qua- } \\
\text { dro 19) } \\
\text { - Outros solventes orgânicos neurotóxicos } \\
\text { (X46.-; X49.-; Z57.5) }\end{array}$ \\
\hline $\begin{array}{l}\text { Transtorno Mental Or- } \\
\text { gânico ou Sintomático } \\
\text { não especificado (F09.) }\end{array}$ & $\begin{array}{l}\text { - Tolueno e outros solventes aromáticos } \\
\text { neurotóxicos (X46.-; Z57.5) (Quadro 3) } \\
\text { - Tricloroetileno, Tetracloroetileno, } \\
\text { Tricloroetano e outros solventes orgânicos } \\
\text { halogenados neurotóxicos (X46.-; Z57.5) } \\
\text { (Quadro 13) } \\
\text { - Brometo de Metila (X46.-; Z57.5) (Qua- } \\
\text { dro 13) }\end{array}$ \\
\hline
\end{tabular}




\begin{tabular}{|c|c|}
\hline & $\begin{array}{l}\text { - Manganês e seus compostos tóxicos } \\
\text { (X49.-; Z57.5) (Quadro 15) } \\
\text { - Mercúrio e seus compostos tóxicos (X49.; } \\
\text { Z57.4 e Z57.5) (Quadro 16) } \\
\text { - Sulfeto de Carbono (X49.-; Z57.5) (Qua- } \\
\text { dro 19) } \\
\text { - Outros solventes orgânicos neurotóxicos } \\
\text { (X46.-; X49.-; Z57.5) }\end{array}$ \\
\hline $\begin{array}{l}\text { Transtornos mentais e } \\
\text { comportamentais devi- } \\
\text { dos ao uso do álcool: Al- } \\
\text { coolismo Crônico (Rela- } \\
\text { cionado com o Trabalho) } \\
\text { (F10.2) }\end{array}$ & $\begin{array}{l}\text { - Problemas relacionados com o emprego e } \\
\text { com o desemprego: Condições difíceis de } \\
\text { trabalho (Z56.5) } \\
\text { - Circunstância relativa às condições de tra- } \\
\text { balho (Y96) }\end{array}$ \\
\hline $\begin{array}{l}\text { Episódios Depressivos } \\
\text { (F32.-) }\end{array}$ & $\begin{array}{l}\text { - Tolueno e outros solventes aromáticos } \\
\text { neurotóxicos (X46.-; Z57.5) (Quadro 3) } \\
\text { - Tricloroetileno, Tetracloroetileno, Triclo- } \\
\text { roetano e outros solventes orgânicos halo- } \\
\text { genados neurotóxicos (X46.-; Z57.5) (Qua- } \\
\text { dro 13) } \\
\text { - Brometo de Metila (X46.-;Z57.4 e Z57.5) } \\
\text { (Quadro 13) } \\
\text { - Manganês e seus compostos tóxicos } \\
\text { (X49.-; Z57.5) (Quadro 15) } \\
\text { - Mercúrio e seus compostos tóxicos (X49.- } \\
\text {;Z57.4 e Z57.5) (Quadro 16) } \\
\text { - Sulfeto de Carbono (X49.-; Z57.5) (Qua- } \\
\text { dro 19) } \\
\text { - Outros solventes orgânicos neurotóxicos } \\
\text { (X46.-; X49.-; Z57.5) }\end{array}$ \\
\hline $\begin{array}{l}\text { Reações ao "Stress" Gra- } \\
\text { ve e Transtornos de } \\
\text { Adaptação(F43.-): Esta- } \\
\text { do de "Stress" Pós-Trau- } \\
\text { mático (F43.1) }\end{array}$ & $\begin{array}{l}\text { - Outras dificuldades físicas e mentais re- } \\
\text { lacionadas com o trabalho: reação após aci- } \\
\text { dente do trabalho grave ou catastrófico, ou } \\
\text { após assalto no trabalho (Z56.6) } \\
\text {-Circunstância relativa às condições de tra- } \\
\text { balho (Y96) }\end{array}$ \\
\hline $\begin{array}{l}\text { Neurastenia (Inclui } \\
\text { "Síndrome de Fadiga") } \\
(\mathrm{F} 48.0)\end{array}$ & $\begin{array}{l}\text { - Tolueno e outros solventes aromáticos } \\
\text { neurotóxicos (X46.-; Z57.5) (Quadro 3) } \\
\text { - Tricloroetileno, Tetracloroetileno, Triclo- } \\
\text { roetano e outros solventes orgânicos } \\
\text { halogenados (X46.-; Z57.5) (Quadro 13) } \\
\text { - Brometo de Metila (X46.-;Z57.4 e Z57.5) } \\
\text { (Quadro 13) } \\
\text { - Manganês e seus compostos tóxicos } \\
\text { (X49.-; Z57.5) (Quadro 15) } \\
\text { - Mercúrio e seus compostos tóxicos (X49.- } \\
\text {;Z57.4 e Z57.5) (Quadro 16) } \\
\text { - Sulfeto de Carbono (X49.-;Z57.5) (Qua- } \\
\text { dro 19) } \\
\text { - Outros solventes orgânicos neurotóxicos } \\
\text { (X46.-; X49.-; Z57.5) }\end{array}$ \\
\hline $\begin{array}{l}\text { Outros transtornos neu- } \\
\text { róticos especificados (In- } \\
\text { clui "Neurose Profissio- } \\
\text { nal") (F48.8) }\end{array}$ & $\begin{array}{l}\text { - Problemas relacionados com o emprego e } \\
\text { com o desemprego (Z56.-): Desemprego } \\
\text { (Z56.0); Mudança de emprego (Z56.1); } \\
\text { Ameaça de perda de emprego (Z56.2); Rit- } \\
\text { mo de trabalho penoso (Z56.3); Desacordo } \\
\text { com patrão e colegas de trabalho (Condi- }\end{array}$ \\
\hline
\end{tabular}

\begin{tabular}{|c|c|}
\hline & $\begin{array}{l}\text { ções difíceis de trabalho) (Z56.5); Outras } \\
\text { dificuldades físicas e mentais relacionadas } \\
\text { com o trabalho (Z56.6) }\end{array}$ \\
\hline $\begin{array}{l}\text { Transtorno do Ciclo Vi- } \\
\text { gília-Sono Devido a Fa- } \\
\text { tores Não-Orgânicos } \\
\text { (F51.2) }\end{array}$ & $\begin{array}{l}\text { Problemas relacionados com o emprego e } \\
\text { com o desemprego: Má adaptação à orga- } \\
\text { nização do horário de trabalho (Trabalho } \\
\text { em Turnos ou Trabalho Noturno) (Z56.6) } \\
\text {-Circunstância relativa às condições de tra- } \\
\text { balho (Y96) }\end{array}$ \\
\hline $\begin{array}{l}\text { Sensação de Estar Aca- } \\
\text { bado ("Síndrome de } \\
\text { Burn-Out", "Síndrome } \\
\text { do Esgotamento Profis- } \\
\text { sional") (Z73.0) }\end{array}$ & $\begin{array}{l}\text { - Ritmo de trabalho penoso (Z56.3) } \\
\text { - Outras dificuldades físicas e mentais rela- } \\
\text { cionadas com o trabalho (Z56.6) }\end{array}$ \\
\hline
\end{tabular}

\section{DOENÇAS DO SISTEMA NERVOSO RELACIONADAS COM O TRABALHO} (Grupo VI da CID-10)

\begin{tabular}{|l|l|}
\hline \multicolumn{1}{|c|}{ Doenças } & $\begin{array}{l}\text { Agentes etiológicos ou fatores de risco } \\
\text { de natureza ocupacional }\end{array}$ \\
\hline $\begin{array}{l}\text { Ataxia Cerebelosa } \\
\text { (G11.1) }\end{array}$ & -Mercúrio seus compostos tóxicos (X49.; \\
Z57.4 e Z57.5) (Quadro 16) \\
$\begin{array}{l}\text { Parkisonismo Secundário } \\
\text { devido a outros agentes } \\
\text { externos (G21.2) }\end{array}$ & - Manganês e seus compostos tóxicos \\
(X49.-; Z57.5) (Quadro 15) \\
$\begin{array}{l}\text { Outras formas especifi- } \\
\text { cadas de tremor (G25.2) }\end{array}$ & $\begin{array}{l}\text { - Brometo de metila (X46.-; Z57.4 e Z57.5) } \\
\text { (Quadro 13) }\end{array}$ \\
\hline
\end{tabular}

cadas de tremor (G25.2) (Quadro 13)

- Tetracloroetano (X46.-; Z57.5) (Quadro 13)

- Mercúrio e seus compostos tóxicos (X49. Z57.4 e Z57.5) (Quadro 16)

-Outros solventes orgânicos neurotóxicos (X46.-; X49.-; Z57.5)

Transtorno extrapiramidal - Mercúrio e seus compostos tóxicos (X49.do movimentonão especi- ; Z57.4 e Z57.5) (Quadro 16)

ficado (G25.9) $\quad$ - Cloreto de metileno (Diclorometano) e outros solventes halogenados neurotóxicos (X46.-; Z57.5) (Quadro 13)

Distúrbios do Ciclo Vi- - Problemas relacionados com o emprego e gília-Sono (G47.2) com o desemprego: Má adaptação à organização do horário de trabalho (Trabalho em Trunos ou Trabalho Noturno) (Z56.6)

Transtornos do nervo tri- - Tricloroetileno e outros solventes halogêmio (G50.-) genados neurotóxicos (X46.-; Z57.5) (Quadro 13)

Transtornos do nervo - Cádmio ou seus compostos (X49.-; olfatório (G52.0) (Inclui Z57.5) (Quadro 6)

"Anosmia") (Quadro 17)

Transtornos do plexo - Posições forçadas e gestos repetitivos 
braquial (Síndrome daSa- (Z57.8)

ída do Torax, Síndrome

do Desfiladeiro Torácico)

(G54.0)

Mononeuropatias dos - Posições forçadas e gestos repetitivos Membros Superiores (G (Z57.8)

56.-): Síndrome do Túnel

do Carpo (G56.0); Outras

Lesões do Nervo Media-

no: Síndrome do Pronador

Redondo (G56.1); Sín-

drome do Canal de Guyon

(G56.2); Lesão do Nervo

Cubital (ulnar): Sindrome

do Túnel Cubital (G56.2);

Lesão do Nervo Radial

(G56.3); Outras Mo-

noneuropatias dos Mem-

bros Superiores: Com-

pressão do Nervo Supra-

escapular (G56.8)

Mononeuropatias do - Posições forçadas e gestos repetitivos membro inferior (G57.): (Z57.8)

Lesão do Nervo Poplíteo

Lateral (G57.3)

Polineuropatia devido a - Arsênio e seus compostos arsenicais outros agentes tóxicos (X49.-; Z57.4 e Z57.5) (Quadro 1)

(G62.2)

- Chumbo e seus compostos tóxicos (X49.

;Z57.5) (Quadro 8)

- Fósforo (X48.-; X49.-; Z57.4 e Z57.5)

(Quadro 12)

- Sulfeto de Carbono (X49.-; Z57.5)(Quadro 19)

- n-Hexano (X46.-; Z57.5) (Quadro 13)

- Metil-n-Butil Cetona (MBK) (X46.-; Z57.5)

Polineuropatia induzida - Radiações ionizantes (X88.-;Z57.1) (Quapela radiação (G62.8) dro 24)

Encefalopatia Tóxica - Arsênio e seus compostos arsenicais Aguda (G92.1) X49.-;Z57.4 e Z57.5) (Quadro 1) - Chumbo e seus compostos tóxicos (X49. Z57.5) (Quadro 8)

- Hidrocarbonetos alifáticos ou aromáticos (seus derivados halogenados neurotóxicos) (X46.-; Z57.5) (Quadro 13)

- Mercúrio e seus derivados tóxicos (X49.:Z57.4 e Z57.5) (Quadro 16)

Encefalopatia Tóxica - ToluenoeXileno(X46.-;Z57.5)(Quadro 3) Crônica (G92.2) Chumbo e seus compostos tóxicos (X49. ;Z57.5) (Quadro 8)

- Solventes orgânicos halogenados neurotóxicos (X46.-; Z57.5) (Quadro 13) -Mercúrio e seus compostos tóxicos (X49.ZZ57.5) (Quadro 16)

-Substâncias asfixiantes: $\mathrm{CO}, \mathrm{H}_{2} \mathrm{~S}$, etc. (seqüela) (X47.-;Z57.5) (Quadro 17)
- Sulfeto de Carbono (X49.-; Z57.5) (Quadro 19)

DOENÇAS DO OLHO E ANEXOS RELACIONADAS COM O TRABALHO (Grupo VII do CID-10)

\begin{tabular}{|c|c|}
\hline Doenças & $\begin{array}{c}\text { Agentes etiológicos ou fatores de risco } \\
\text { de natureza ocupacional }\end{array}$ \\
\hline Blefarite (H01.0) & $\begin{array}{l}\text { - Arsênio e seus compostos arsenicais } \\
\text { (X49.-; Z57.4 e Z57.5) (Quadro 1) } \\
\text { - Radiações Ionizantes (W88.-;Z57.1) (Qua- } \\
\text { dro 24) } \\
\text { - Cimento (X49.-; Z57.2) }\end{array}$ \\
\hline Conjuntivite (H10) & $\begin{array}{l}\text { - Arsênio e seus compostos arsenicais } \\
\text { (X49.-; Z57.4 e Z57.5) (Quadro 1) } \\
\text { - Berílio e seus compostos tóxicos (X49.-; } \\
\text { Z57.5) (Quadro 4) } \\
\text { - Flúor e seus compostos tóxicos (X49.-) } \\
\text { (Quadro 11) } \\
\text { - Iodo (X49.-; Z57.5) (Quadro 14) } \\
\text {-Cloreto de etila (X46.-;Z57.5) (Quadro 13) } \\
\text { - Tetracloreto de carbono (X46.-; Z57.5) } \\
\text { (Quadro 13) } \\
\text { - Outros solventes halogenados tóxicos } \\
\text { (X46.-;Z57.4 e Z57.5) (Quadro 13) } \\
\text { - Ácido sulfídrico (Sulfeto de hidrogênio) } \\
\text { (X49.-;Z57.5) (Quadro 17) } \\
\text { - Radiações ionizantes (W88.-;Z57.1)(Qua- } \\
\text { dro 24) } \\
\text { - Radiações Ultravioletas (W89;Z57.1 } \\
\text { - Acrilatos (X49.-;Z57.5) } \\
\text { - Cimento (X49.-;Z57.2) } \\
\text { - Enzimas de origem animal, vegetal ou } \\
\text { bacteriana (X44.-;Z57.2) } \\
\text { - Furfural e Álco61 Furfurílico (X45.-; } \\
\text { Z57.5) } \\
\text { - Isocianatos orgânicos (X49.-;Z57.5) } \\
\text { - Selênio e seus compostos (X49.-;Z57.5) }\end{array}$ \\
\hline $\begin{array}{l}\text { Queratite e Queratocon- } \\
\text { juntivite (H16) }\end{array}$ & $\begin{array}{l}\text { - Arsênio e seus compostos arsenicais } \\
\text { (X49.-; Z57.4 e Z57.5) (Quadro 1) } \\
\text { - Ácido sulfídrico (Sulfeto de hidrogênio) } \\
\text { (X49.-; Z57.5) (Quadro 17) } \\
\text { - Radiações ionizantes (W88.-;Z57.1) (Qua- } \\
\text { dro 24) } \\
\text { - Radiaçōes Infravermelhas (W90.-;Z57.1) } \\
\text { - Radiaçōes Ultravioletas (W89.-;Z57.1) }\end{array}$ \\
\hline Catarata $(\mathrm{H} 28)$ & $\begin{array}{l}\text { - Radiações ionizantes (W88.-;Z57.1) (Qua- } \\
\text { dro 24) } \\
\text { - Radiações Infravermelhas (W90.-; Z57.1) }\end{array}$ \\
\hline
\end{tabular}

Inflamação Coriorreti- - Manganês e seus compostos tóxicos niana $(\mathrm{H} 30)$ (X49.-; Z57.5) (Quadro 15)

Neurite Óptica (H46) - Brometo de metila (X46.-; Z57.4 e Z57.5) (Quadro 13)

- Cloreto de metileno (Diclorometano) e outros solventes clorados neurotóxicos 


\begin{tabular}{|c|c|}
\hline $\begin{array}{l}\text { Distúrbios visuais subje- } \\
\text { tivos (H53.-) }\end{array}$ & $\begin{array}{l}\text { (X46.-; Z57.5) (Quadro 13) } \\
\text { - Tetracloreto de carbono (X46.-; Z57.5) } \\
\text { (Quadro 13) } \\
\text {-Sulfeto de Carbono (X49.-;Z57.5)(Quadro } \\
\text { 19) } \\
\text { - Metanol (X45.-;Z57.5) } \\
\\
\text { - Brometo de metila (X46.-;Z57.4 eZ57.5) } \\
\text { (Quadro 13) } \\
\text { - Cloreto de metileno e outros solventes } \\
\text { clorados neurotóxicos (X46.-;Z57.5) (Qua- } \\
\text { dro 13) }\end{array}$ \\
\hline \multicolumn{2}{|c|}{$\begin{array}{l}\text { DOENÇAS DO OUVIDO RELACIONADAS COM O TRABALHO } \\
\text { (Grupo VIII da (ID-10) }\end{array}$} \\
\hline Doenças & $\begin{array}{l}\text { Agentes etiológicos ou fatores de risco } \\
\text { de natureza ocupacional }\end{array}$ \\
\hline $\begin{array}{l}\text { Otite Média não-supu- } \\
\text { rativa (H65.9) }\end{array}$ & $\begin{array}{l}\text { - “Ar Comprimido" (W94.-; Z57.8) (Qua- } \\
\text { dro 23) } \\
\text { - Pressão atmosférica inferior à pressão } \\
\text { padrão (W94.-;Z57.8) }\end{array}$ \\
\hline $\begin{array}{l}\text { Perfuração da Membra- } \\
\text { na do Tímpano (H72 ou }\end{array}$ & $\begin{array}{l}\text { - "Ar Comprimido" (W94.-; Z57.8) (Tabe- } \\
\text { la 23) }\end{array}$ \\
\hline S09.2) & $\begin{array}{l}\text { - Pressão atmosférica inferior à pressão } \\
\text { padrão (W94.-;Z57.8) }\end{array}$ \\
\hline $\begin{array}{l}\text { Outras vertigens perifé- } \\
\text { ricas }(\mathrm{H} 81.3)\end{array}$ & $\begin{array}{l}\text { - Cloreto de metileno e outros solventes } \\
\text { halogenados tóxicos (X46.-; Z57.5) (Qua- } \\
\text { dro 13) }\end{array}$ \\
\hline Labirintite (H81.3) & $\begin{array}{l}\text { - Brometo de metila (X46.-; Z57.4 e Z57.5) } \\
\text { (Quadro 13) } \\
\text {-"Ar Comprimido" (W94.--;Z57.8) (Qua- } \\
\text { dro 23) }\end{array}$ \\
\hline $\begin{array}{l}\text { Efeitos do ruído sobre o } \\
\text { ouvido interno/ Perda da } \\
\text { Audição Provocada pelo } \\
\text { Ruído e Trauma Acústi- } \\
\text { co (H83.3) }\end{array}$ & $\begin{array}{l}\text { - Exposição ocupacional ao Ruído (Z57.0; } \\
\text { W42.-) (Quadro 21) }\end{array}$ \\
\hline $\begin{array}{l}\text { Hipoacusia Ototóxica } \\
\text { (H91.0) }\end{array}$ & $\begin{array}{l}\text { 60.Homologos do Benzeno otoneuroto- } \\
\text { xicos (Tolueno e Xileno) (X46.-; Z57.5) } \\
\text { (Quadro 3) } \\
\text {-Solventes orgânicos otoneurotóxicos } \\
\text { (X46.-;Z57.8) (Quadro 13) }\end{array}$ \\
\hline $\begin{array}{l}\text { Otalgia e Secreção Audi- } \\
\text { tiva (H92.-): Otalgia } \\
(\text { H92.0), Otorréia } \\
(\text { H92.1) ou Otorragia } \\
(\text { H92.2) }\end{array}$ & $\begin{array}{l}\text { - "Ar Comprimido" (W94.-; Z57.8) (Qua- } \\
\text { dro 23) }\end{array}$ \\
\hline $\begin{array}{l}\text { Outras percepções audi- } \\
\text { tivas anormais: Alteração } \\
\text { Temporária do Limiar } \\
\text { Auditivo, Comprometi- }\end{array}$ & $\begin{array}{l}\text { - Exposição ocupacional ao Ruído (Z57.0; } \\
\text { X42.-) (Quadro 21) } \\
\text { Outros transtornos especificados do ouvi- }\end{array}$ \\
\hline
\end{tabular}

\begin{tabular}{|c|c|}
\hline & \\
\hline $\begin{array}{l}\text { mento da Discriminação } \\
\text { Auditiva e Hiperacusia } \\
\text { (H93.2) }\end{array}$ & $\begin{array}{l}\text { do (H93.8) - Brometo de metila (X46.- } \\
\text {;Z57.4 e Z57.5) (Quadro 13) } \\
\text { "“Ar Comprimido"(W94.-;Z57.8) (Qua- } \\
\text { dro 23) }\end{array}$ \\
\hline $\begin{array}{l}\text { Otite Barotraumática } \\
(\mathrm{T} 70.0)\end{array}$ & $\begin{array}{l}\text { - "Ar Comprimido" (W94.-;Z57.8) (Qua- } \\
\text { dro 23) } \\
\text { - Alterações na pressão atmosférica ou na } \\
\text { pressão da água no ambiente (W94.-;Z57.8) }\end{array}$ \\
\hline $\begin{array}{l}\text { Sinusite Barotraumática } \\
\text { (T70.1) }\end{array}$ & $\begin{array}{l}\text { - "Ar Comprimido" (W94.-; Z57.8) (Qua- } \\
\text { dro 23) } \\
\text { - Alterações na pressão atmosférica ou na } \\
\text { pressão da água no ambiente (W94.-) }\end{array}$ \\
\hline $\begin{array}{l}\text { "Mal dos Caixões" (Do- } \\
\text { ença de Descompressão) } \\
\text { (T70.4) }\end{array}$ & $\begin{array}{l}\text { - “Ar Comprimido" (W94.-; Z57.8)(Quadro } \\
\text { 23) } \\
\text { - Alterações na pressão atmosférica ou na } \\
\text { pressão da água no ambiente (W94.-;Z57.8) }\end{array}$ \\
\hline $\begin{array}{l}\text { Síndrome devida ao des- } \\
\text { locamento de ar de uma } \\
\text { explosão (T70.8) }\end{array}$ & $\begin{array}{l}\text { - "Ar Comprimido" (W94.-; Z57.8) (Qua- } \\
\text { dro 23) } \\
\text { - Alterações na pressão atmosférica ou na } \\
\text { pressão da água no ambiente (W94.-;Z57.8) }\end{array}$ \\
\hline $\begin{array}{r}\text { DOENÇAS DO SISTEM } \\
\text { TRABA }\end{array}$ & $\begin{array}{l}\text { A CIRCULATÓRIO RELACIONADAS COM } 0 \\
\text { LHO (Grupo IX da (ID-10) }\end{array}$ \\
\hline Doenças & $\begin{array}{c}\text { Agentes etiológicos ou fatores de risco } \\
\text { de natureza ocupacional }\end{array}$ \\
\hline $\begin{array}{l}\text { Hipertensão Arterial } \\
\text { (I10.-) }\end{array}$ & $\begin{array}{l}\text { - Chumbo ou seus compostos tóxicos } \\
\text { (X49.-; Z57.5) (Quadro 8) } \\
\text {-Exposição ocupacional ao Ruído (Z57.0; } \\
\text { X42.-) (Quadro 21) } \\
\text {-Problemas relacionados com o emprego e } \\
\text { com o desemprego (Z56.-) }\end{array}$ \\
\hline Angina Pectoris (I20.-) & $\begin{array}{l}\text { - Monóxido de Carbono (X47.-; Z57.5) } \\
\text { (Quadro 17.1) } \\
\text { - Sulfeto de Carbono (X49.-;Z57.5)(Quadro } \\
\text { 19) } \\
\text { - Nitroglicerina e outros ésteres do ácido } \\
\text { nítrico (X49.-:Z57.5) } \\
\text { - Problemas relacionados com o emprego e } \\
\text { com o desemprego (Z56.-) }\end{array}$ \\
\hline $\begin{array}{l}\text { Infarto Agudo do Mio- } \\
\text { cárdio (I21.-) }\end{array}$ & $\begin{array}{l}\text {-Monóxido de Carbono (X47.-; Z57.5) } \\
\text { (Quadro 17.1) } \\
\text {-Sulfeto de Carbono (X49.-;Z57.5)(Quadro } \\
\text { 19) } \\
\text {-Nitroglicerina e outros ésteres do ácido } \\
\text { nítrico (X49.-;Z57.5) } \\
\text {-Problemas relacionados com o emprego e } \\
\text { com o desemprego (Z56.-) }\end{array}$ \\
\hline $\begin{array}{l}\text { Cor Pulmonale SOE ou } \\
\text { Doença Cardiopulmonar } \\
\text { Crônica (I27.9) }\end{array}$ & $\begin{array}{l}\text { - Complicação evolutiva das pneumoco- } \\
\text { nioses graves, principalmente Silicose } \\
\text { (Z57.2) (Quadro 18) }\end{array}$ \\
\hline
\end{tabular}


Placas epicárdicas ou - Asbesto ou Amianto (W83.-; Z57.2) pericárdicas (134.8)

(Quadro 2)

Parada Cardíaca (I46.) Derivados halogenados dos hidrocarbonetos alifáticos (X46.-) (Quadro 13)

-Monóxido de Carbono (X47.-; Z57.5)

(Quadro 17.1)

Outros agentes potencialmente causadores de arritmia cardíaca (Z57.5)

Arritmias cardíacas (149.-) ·Arsênio e seus compostos arsenicais (X49.-; Z57.5) (Quadro 1)

-Chumbo ou seus compostos tóxicos (X49.;Z57.5) (Quadro 8)

- Derivados halogenados dos hidrocar-bonetos alifáticos (X46.-;Z57.5) (Quadro 13)

-Mercúrio e seus compostos tóxicos (X49.;

Z57.5) (Quadro 16)

-Monóxido de Carbono (X47.-; Z57.5)

(Quadro 17.1)

-Agrotóxicos organofosforados e

carbamatos (X48; Z57.4) (Quadros $12 \mathrm{e}$ 27)

-Exposição ocupacional a Cobalto (X49.-; Z57.5)

-Nitroglicerina e outros ésteres do ácido nítrico (X49.-; Z57.5)

-Problemas relacionados com o emprego e com o desemprego (Z56.-)

- Sulfeto de carbono (X49.-;Z57.5)(Quadro 19)

Ateroesclerose (170.-) e Síndrome de Raynaud (173.0) - Cloreto Doença Ateroesclerótica de vinila (X46.-; Z57.5)(Quadro 13) do Coração (I25.1) - Vibrações localizadas (W43.-; Z57.7) (Quadro 22)

- Trabalho em baixas temperaturas (frio) (W93.-;Z57.6)

Acrocianose e Acropa- - Cloreto de vinila (X46.-; Z57.5) (Quadro restesia (173.8)

13)

- Vibrações localizadas (W43.-; Z57.7) (Quadro 22)

- Trabalho em baixas temperaturas (frio) (W93.-;Z57.6)

DOENÇAS DO SISTEMA RESPIRATÓRIO RELACIONADAS COM O TRABALHO (Grupo X do CID-10)

\begin{tabular}{cc}
\hline Doenças & $\begin{array}{c}\text { Agentes etiológicos ou fatores de Risco } \\
\text { de Natureza Ocupacional }\end{array}$ \\
\hline
\end{tabular}

Faringite Aguda, não - Bromo (X49.-; Z57.5) (Quadro 5) especificada ("Angina - Iodo (X49.-; Z57.5)(Quadro 14)

Aguda", "Dor de Gar-

ganta") (J02.9)

Laringotraqueíte Aguda - Bromo (X49.-; Z57.5) (Quadro 5)

(J04.2) - Iodo (X49.-; Z57.5)(Quadro 14)
Outras Rinites Alérgicas 'Carbonetos metálicos de tungstênio (J30.3) sinterizados (X49.-; Z57.2 e Z57.5) (Quadro 7)

Cromo e seus compostos tóxicos (X49.-; Z57.5) (Quadro 10)

. Poeiras de algodão, linho, cânhamo ou sisal (Z57.2) (Quadro 26)

-Acrilatos (X49.-; Z57.5)

-Aldeído fórmico e seus polímeros (X49.-;

Z57.5)

-Aminas aromáticas e seus derivados $(\mathrm{X} 49$. Z57.5)

-Anidrido ftálico (X49.-;Z57.5)

-Azodicarbonamida (X49.-;Z57.5)

Carbetos de metais duros: cobalto e titânio (Z57.2)

-Enzimas de origem animal, vegetal ou bacteriano (X44.-; Z57.3)

-Furfural e Álcoól Furfurílico (X45.Z57.5)

-Isocianatos orgânicos (X49.-:Z57.5)

- Níquel e seus compostos (X49.-; Z57.5)

-Pentóxido de vanádio (X49.-; Z57.5)

Produtos da pirólise de plásticos, cloreto

de vinila, teflon (X49.-;Z57.5)

Sulfitos, bissulfitos e persulfatos (X49.-

Z57.5)

Medicamentos: macrólidos; ranetidina penicilina e seus sais; cefalosporinas (X44. ;Z57.3)

Proteínas animais em aerossóis (Z57.3)

-Outras substâncias de origem vegetal (cereais, farinhas, serragem, etc.) (Z57.2)

Outras susbtâncias químicas sensibilizantes da pele e das vias respiratórias (X49.-; Z57.2) (Quadro 27)

Rinite Crônica (J31.0) - Arsênico e seus compostos arsenicais (X49.-; Z57.4 e Z57.5) (Quadro 1)

- Cloro gasoso (X47.-; Z57.5)(Quadro 9)

- Cromo e seus compostos tóxicos (X49.-) (Quadro 10)

- Gás de flúor e Fluoreto de Hidrogênio (X47.-; Z57.5) (Quadro 11)

- Amônia (X47.-;Z57.5)

- Anidrido sulfuroso (X49.-; Z57.5)

- Cimento (Z57.2)

- Fenol e homólogos (X46.-;Z57.5)

- Névoas de ácidos minerais (X47.-;Z57.5)

- Níquel e seus compostos (X49.-; Z57.5)

- Selênio e seus compostos (X49.-;Z57.5)

Faringite Crônica (J31.2) - Bromo (X49.-;Z57.5)(Quadro 5)

Sinusite Crônica (J32.-) - Bromo (X49.-; Z57.5)(Quadro 5) - Iodo (X49.-; Z57.5)(Quadro 14)

Ulceração ou Necrose do - Arsênio e seus compostos arsenicais Septo Nasal (J34.0) (X49.-; Z57.4 e Z57.5) (Quadro 1)

- Cádmio ou seus compostos (X49.-Z57.5) (Quadro 6)

- Cromo e seus compostos tóxicos (X49.-; 


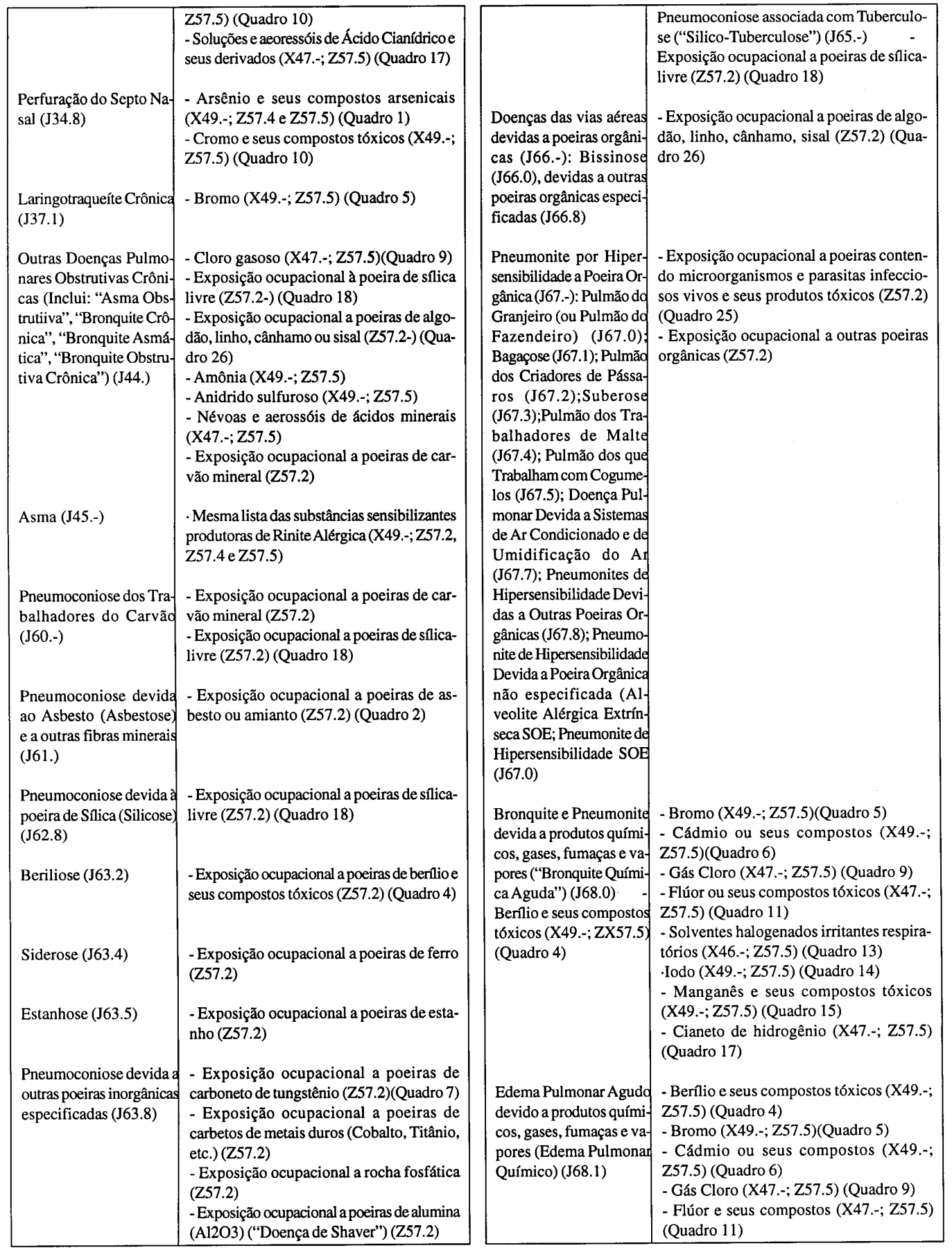


- Solventes halogenados irritantes respiratórios (X46.-; Z57.5) (Quadro 13)

- Iodo (X49.-; Z57.5) (Quadro 14)

- Cianeto de hidrogênio (X47.-; Z57.5)

(Quadro 17)

Síndrome de Disfunção - Bromo (X49.-; Z57.5) (Quadro 5) Reativa das Vias Aéreas - Cádmio ou seus compostos (X49.-: (SDVA/RADS) (J68.3) Z57.5) (Quadro 6)

- Gás Cloro (X47.-; Z57.5)(Quadro 9)

- Solventes halogenados irritantes respiratórios (X46.-; Z57.5) (Quadro 13)

- Iodo (X49.-; Z57.5)(Quadro 14)

- Cianeto de hidrogênio (X47.-; Z57.5)

(Quadro 17)

-Amônia (X49.-;Z57.5)

Afecç̧ões respiratórias - Arsênico e seus compostos arsenicais crônicas devidas à inala- (X49.-; Z57.4 e Z57.5) (Quadro 1) ção de gases, fumos, va- - Berílio e seus compostos (X49.-; Z57.5) pores e substâncias quími- (Quadro 4)

cas: Bronquiolite Obli- - Bromo (X49.-; Z57.5)(Quadro 5) terante Crônica, Enfisema - Cádmio ou seus compostos (X49.-; Crônico Difuso, Fibrose Z57.5) (Quadro 6)

Pulmonar Crônica (J68.4) - Gás Cloro (X47.-; Z57.5) (Quadro 9)

- Flúor e seus compostos (X47.-; Z57.5) (Quadro 11)

- Solventes halogenados irritantes respiratórios (X46.-; Z57.5) (Quadro 13)

- Iodo (X49.-; Z57.5)(Quadro 14)

- Manganês e seus compostos tóxicos

(X49.-; Z57.5) (Quadro 15)

- Cianeto de hidrogênio (X47.-; Z57.5)(Quadro 17)

- Ácido Sulfídrico (Sulfeto de hidrogênio)

(X47.-; Z57.5) (Quadro 17)

- Carbetos de metais duros (X49.-; Z57.5)

- Amônia (X49.-; Z57.5)

- Anidrido sulfuroso (X49.-; Z57.5)

- Névoas e aerossóis de ácidos minerais (X47.-; Z57.5)

- Acrilatos (X49.-; Z57.5)

- Selênio e seus compostos (X49.-;Z57.5)

Pneumonite por Radiação - Radiações ionizantes (W88.-;Z57.1) (Qua(manifestação aguda) dro 24)

(J70.0) e Fibrose Pulmo-

nar Consequiente à Radi-

ação (manifestação crôni-

ca) $(\mathbf{J} 70.1)$

Derrame pleural (J90.-) - Exposição ocupacional a poeiras de Asbesto ou Amianto (Z57.2) (Quadro 2)

Placas pleurais (J92.-) - Exposição ocupacional a poeiras de Asbesto ou Amianto (Z57.2)(Quadro 2)

Enfisema intersticial - Cádmio ou seus compostos (X49.-; (J98.2) Z57.5) (Quadro 6)

Transtornos respiratórios - Exposição ocupacional a poeiras de Carem outras doenças sistê- vão Mineral (Z57.2) micas do tecido conjunti- - Exposição ocupacional a poeiras de Sílica vo classificadas em outra livre (Z57.2) (Quadro 18) parte (M05.3): "Síndrome

de Caplan" (J99.1)

DOENÇAS DO SISTEMA DIGESTIVO RELACIONADAS COM O TRABALHO (Grupo XI da CID-10)

\begin{tabular}{cc}
\hline Doenças & $\begin{array}{c}\text { Agentes etiológicos ou fatores de risco } \\
\text { de natureza ocupacional }\end{array}$ \\
\hline
\end{tabular}

Erosão Dentária (K03.2) · Névoas de fluoretos ou seus compostos tóxicos (X47.-; Z57.5) (Quadro 11) -Exposição ocupacional a outras névoas ácidas (X47.-; Z57.5)

Alterações pós-eruptivas · Névoas de Cádmio ou seus compostos da cor dos tecidos duros (X47.-; Z57.5) (Quadro 6)

dos dentes (K03.7) -Exposição ocupacional a metais: Cobre, Níquel, Prata (X47.-;Z57.5)

Gengivite Crônica(K05.1) Mercúrio e seus compostos tóxicos (X49.; Z57.5) (Quadro 16)

Estomatite Ulcerativa - Arsênio e seus compostos arsenicais Crônica (K12.1) (X49.-; Z57.5) (Quadro 1) - Bromo (X49.-; Z57.5) (Quadro 12. - Mercúrio e seus compostos tóxicos (X49.; Z57.5) (Quadro 16)

Gastroenterite e Colite - Arsênio e seus compostos arsenicais tóxicas (K52.-) (X49.-; Z57.5) (Quadro 1)

.Cádmio ou seus compostos (X49.-;Z57.5) (Quadro 6) -Radiações ionizantes (W88.-; Z57.1) (Quadro 24)

Outros transtomos funci- - Chumbo ou seus compostos tóxicos onais do intestino ("Sín- (X49.-; Z57.5) (Quadro 8)

drome dolorosa abdomi-

nal paroxística apirética,

com estado suboclusivo

("cólica do chumbo")

(K59.8)

Doença Tóxica do Fígado - Cloreto de Vinila, Clorobenzeno, (K71.-): Doença Tóxicado Tetracloreto de Carbono, Clorofórmio, e Fígado, com Necrose He- outros solventes halogenados hepatotóxicos pática (K71.1); Doença (X46.- e X48.-;Z57.4 e Z57.5) (Quadro 13) T6́xica do Fígado, com ·Hexaclorobenzeno (HCB) (X48.-; Z57.4 Hepatite Aguda (K71.2); e Z57.5)

Doença Tóxica do Fígado - Bifenilas policloradas (PCBs) (X49.-; com Hepatite Crônica Per- Z57.4 e Z57.5)

sistente (K71.3); Doença ·Tetraclorodibenzodioxina (TCDD) (X49.)

Tóxica do Fígado com

Outros Transtornos Hepá-

ticos (K71.8)

Hipertensão Portal (K76.6) ·Arsênio e seus compostos arsenicais (X49.; Z57.4 e Z57.5) (Quadro 1) Cloreto deVinila (X46.-;Z57.5) (Quadro 13) -Tório (X49.-;Z57.5) 


\begin{tabular}{|c|c|}
\hline \multicolumn{2}{|c|}{$\begin{array}{l}\text { DOENÇAS DA PELE E DO TECIDO SUBCUTÂNEO RELACIONADAS COM } 0 \\
\text { TRABALHO (Grupo XII do (ID-10) }\end{array}$} \\
\hline Doenças & $\begin{array}{c}\text { Agentes etiológicos ou fatores de risco } \\
\text { de natureza ocupacional }\end{array}$ \\
\hline $\begin{array}{l}\text { Outras Infecções Locais } \\
\text { da Pele e do Tecido Sub- } \\
\text { cutâneo: "Dermatoses } \\
\text { Pápulo-Pustulosas e suas } \\
\text { complicaçôes infeccio- } \\
\text { sas" (L08.9) }\end{array}$ & $\begin{array}{l}\text { - Cromo e seus compostos tóxicos (Z57.5) } \\
\text { (Quadro 10) } \\
\text { - Hidrocarbonetos alifáticos ou aromáticos } \\
\text { (seus derivados tóxicos) (Z57.5) (Quadro } \\
\text { 13) } \\
\text { - Microorganismos e parasitas infecciosos } \\
\text { vivos e seus produtos tóxicos (Z57.5) (Qua- } \\
\text { dro 25) } \\
\text { - Outros agentes químicos ou biológicos } \\
\text { que afetem a pele, não considerados em } \\
\text { outras rubricas (Z57.5) (Quadro 27) }\end{array}$ \\
\hline $\begin{array}{l}\text { Dermatite Alérgica de } \\
\text { Contato devido a Metais } \\
\text { (L23.0) }\end{array}$ & $\begin{array}{l}\text { - Cromo e seus compostos tóxicos (Z57.5) } \\
\text { (Quadro 10) } \\
\text { - Mercúrio e seus compostos tóxicos } \\
\text { (Z57.5) (Quadro 16) }\end{array}$ \\
\hline $\begin{array}{l}\text { Dermatite Alérgica de } \\
\text { Contato devido a Adesi- } \\
\text { vos (L23.1) }\end{array}$ & $\begin{array}{l}\text { - Adesivos, em exposição ocupacional } \\
\text { (Z57.5) (Quadro 27) }\end{array}$ \\
\hline $\begin{array}{l}\text { Dermatite Alérgica de } \\
\text { Contato devido a Cosmé- } \\
\text { ticos (fabricação/manipu- } \\
\text { lação) (L23.2) }\end{array}$ & $\begin{array}{l}\text { - Fabricação/manipulação de Cosméticos } \\
\text { (Z57.5) (Quadro 27) }\end{array}$ \\
\hline $\begin{array}{l}\text { Dermatite Alérgica de } \\
\text { Contato devido a Drogas } \\
\text { em contato com a pele } \\
\text { (L23.3) }\end{array}$ & $\begin{array}{l}\text { - Drogas, em exposição ocupacional } \\
\text { (Z57.5) (Quadro 27) }\end{array}$ \\
\hline $\begin{array}{l}\text { Dermatite Alérgica de } \\
\text { Contato devido Corantes } \\
\text { (L23.4) }\end{array}$ & $\begin{array}{l}\text { - Corantes, em exposição ocupacional } \\
\text { (Z57.5) (Quadro 27) }\end{array}$ \\
\hline $\begin{array}{l}\text { Dermatite Alérgica de } \\
\text { Contato devido a outros } \\
\text { produtos químicos (L23.5) }\end{array}$ & $\begin{array}{l}\text { - Cromo e seus compostos tóxicos (Z57.5) } \\
\text { (Quadro 10) } \\
\text { - Fósforo ou seus produtos tóxicos (Z57.5) } \\
\text { (Quadro 12) } \\
\text { - Iodo (Z57.5) (Quadro 14) } \\
\text { - Alcatrão, Breu, Betume, Hulha Mineral, } \\
\text { Parafina ou resíduos dessas substâncias } \\
\text { (Z57.8) (Quadro 20) } \\
\text { - Borracha (Z57.8) (Quadro 27) } \\
\text { - Inseticidas (Z57.5) (Quadro 27) } \\
\text { - Plásticos (Z57.8) (Quadro 27) } \\
\end{array}$ \\
\hline $\begin{array}{l}\text { Dermatite Alérgica de } \\
\text { Contato devido aAlimen- } \\
\text { tos em contato com a pele } \\
\text { (fabricação/ manipula- } \\
\text { ção) (L23.6) }\end{array}$ & $\begin{array}{l}\text { - Fabricação/manipulação de Alimentos } \\
\text { (Z57.5) (Quadro 27) }\end{array}$ \\
\hline $\begin{array}{l}\text { Dermatite Alérgica de } \\
\text { Contato devido a Plantas } \\
\text { (Não inclui plantas usa- }\end{array}$ & $\begin{array}{l}\text { - Manipulação de Plantas, em exposição } \\
\text { ocupacional (Z57.8) (Quadro 27) }\end{array}$ \\
\hline
\end{tabular}

das como alimentos) (L23.7)

Dermatite Alérgica de - Agentes químicos, não especificados anContato devido a outros teriormente, em exposição ocupaciona agentes (Causa Externa (Z57.5) (Quadro 27) especificada) (L23.8)

Dermatite de Contato por - Detergentes, em exposição ocupacional Irritantes devido a Deter- (Z57.5) (Quadro 27) gentes (L24.0)

Dermatite de Contato por - Óleos e Gorduras, em exposição Irritantes devido a Óleos ocupacional (Z57.5) (Quadro 27) e Gorduras (L.24.1)

Dermatite de Contato por $\cdot$ Hidrocarbonetos aromáticos ou alifáticos Irritantes devido a Sol- ou seus derivados halogenados tóxicos ventes: Cetonas, Ciclo- (Z57.5) (Quadro 13)

hexano, Compostos do

Cloro, Ésteres, Glicol, Hidrocarbonetos (L24.2) 60.Benzeno (X46.-; Z57.5) (Quadro 3)

Dermatite de Contato por - Cosméticos, em exposição ocupacional Irritantes devido a Cosméticos (L24.3)

Dermatite de Contato por - Drogas, em exposição ocupacional Irritantes devido a Dro- (Z57.5) (Quadro 27) gas em contato com a pele (L24.4)

Dermatite de Contato por - Arsênio e seus compostos arsenicais Irritantes devido a outros (Z57.5) (Quadro 1)

produtos químicos: Arsê- - Berílio e seus compostos tóxicos (Z57.5) nio, Berílio, Bromo, Cro- (Quadro 4)

mo, Cimento, Flúor, Fós- - Fósforo (Z57.5) (Quadro 12)

foro, Inseticidas (L24.5) - Bromo (Z57.5) (Quadro 5)

- Cromo e seus compostos tóxicos (Z57.5) (Quadro 10)

- Flúor ou seus compostos tóxicos (Z57.5) (Quadro 11)

Dermatite de Contato por - Alimentos, em exposição ocupacional Irritantes devido a Alimentos em contato com a pele (L24.6)

Dermatite de Contato por Irritantes devido a Plantas, exceto alimentos (L24.7)

Dermatite de Contato por - Agentes químicos, não especificados anIrritantes devido a outros teriormente, em exposição ocupacional agentes: Corantes (L24.8)

UrticáriaAlérgica (L50.0) Agrotóxicos e outros produtos químicos (X48.-; Z57.4 e Z57.5) Quadro 27)

Urticária devido ao Calor - Exposição ocupacional a calor e frio 
e ao Frio (L50.2)

(W92,-; W93.-; Z57.6) (Quadro 27)

Urticária de Contato 'Exposição ocupacional a agentes quími(L50.6) $\cos$, físicos e biológicos que afetam a pele (X49.-; Z57.4 e Z57.5) (Quadro 27)

Queimadura Solar(L55) - Exposição ocupacional a radiações actínicas (X32.-;Z57.1) (Quadro 27)

Outras Alterações Agu- - Radiação Ultravioleta (W89.-; Z57.1)

das da Pele devido a Ra- (Quadro 27)

diação Ultravioleta

(L56.): Dermatite por

Fotocontato (Dermatite

de Berloque) (L56.2);

Urticária Solar (L56.3);

Outras Alterações Agu-

das Especificadas da Pele

devidas a Radiação Ul

travioleta(L56.8); Outras

Alterações Agudas da

Pele devidas a Radiação

Ultravioleta, sem outra

especificação (L56.9):

Alterações da Pele devi- - Radiações não-ionizantes (W89.-; X32.-; das a Exposição Crônica Z57.1) (Quadro 27)

a Radiação Não Ionizante

(L57.-): Ceratose Actínica

(L57.0); Outras Altera-

ções: Dermatite Solar

"Pele de Fazendeiro",

"Pele de Marinheiro"

(L57.8)

Radiodermatite (L58.-): - Radiações ionizantes (W88.-;Z57.1) (QuaRadiodermatite Aguda dro 24)

(L58.0); Radiodermatite

Crônica (L58.1); Radio-

dermatite, não especi-

ficada (L58.9); Afecções

da pele e do tecido con-

juntivo relacionadas com

a radiação, não especi-

ficadas (L59.9)

Outras formas de Acne: - Derivados halogenados dos hidrocarbonetos "Cloracne" (L70.8) aromáticos, Monoclorobenzeno, Monobromobenzeno, Hexaclorobenzeno (X46. Z57.5) (Quadro 13)

- Derivados do fenol, pentaclorofenol e do hidrobenzonitrilo (X49,-; Z57.4 e Z57.5) (Quadro 27)

- Policloretos de Bifenila (PCBs) (X49.-; Z57.4 e Z57.5) (Quadro 27)

Outras formas de Cistos - Óleos e gorduras de origem mineral ou Foliculares da Pele e do sintéticos (X49.-; Z57.5) (Quadro 27)

Tecido Subcutâneo: "E-

laioconiose" ou "Der

matite Folicular" (L72.8)
Outras formas de hiper- - Arsênio e seus compostos arsenicais pigmentação pela mela- (X49.-; Z57.4 e Z57.5) (Quadro 1)

nina: "Melanodermia" - Clorobenzeno e Diclorobenzeno (X46.-; (L81.4)

Z57.4 e Z57.5)(Quadro 13)

- Alcatrão, Breu, Betume, Hulha Mineral, Parafina, Creosoto, Piche, Coaltar ou resíduos dessas substâncias (Z57.8) (Quadro 20)

- Antraceno e Dibenzoantraceno (Z57.5) (Quadro 20)

- Bismuto (X44.-;Z57.5) (Quadro 27)

- Citostáticos (X44.-; Z57.5) (Quadro 27)

- Compostos nitrogenados: Ácido nítrico, Dinitrofenol (X49.-; Z57.5) (Quadro 27)

- Naftóis adicionados a corantes (X49,-; Z57.5) (Quadro 27)

- Óleos de corte (Z57.5) (Quadro 27)

- Parafenilenodiamina e seus derivados

(X49.-;Z47.5) (Quadro 27)

- Poeira de determinadas madeiras (Z57.3)

(Quadro 27)

- Quinino e seus derivados (Z57.5) (Quadro 27)

- Sais de ouro (X44.-; Z57.5) (Quadro 27) - Sais de prata (Seqüelas de Dermatite Crônica de Contato) (X44.-;Z57.5) (Quadro 27)

Leucodermia, não clas- - Arsênio e seus compostos (X49.-; Z57.4 e sificada em outra parte (In- Z57.5) (Quadro 1)

clui "Vitiligo Ocupa- - Hidroquinona e ésteres derivados (X49.; cional") (L81.5) Z Z57.5) (Quadro 27)

- Monometil éter de hidroquinona (MBEH) (X49.-; Z57.5) (Quadro 27)

- para-Aminofenol (X49.-; Z57.5) (Quadro 27)

- para-Butilfenol (X49.-;Z57.5) (Quadro 27) - para-Cresol (X49.-; Z57.5) (Quadro 27) - Catecol e Pirocatecol (X49.-; Z57.5) (Quadro 27)

- Clorofenol (X46.-; Z57.4 e Z57.5)(Quadro 27)

Outros transtornos espe- - Derivados halogenados dos hidrocarcificados da pigmenta- bonetos aromáticos: minoclorobenzeno, ção: "Porfiria Cutânea monobromo-benzeno, hexaclorobenzeno Tardia"(L81.8) （X46.-; Z57.4 e Z57.5) (Quadro 13)

Ceratose Palmar e Plan- - Arsênio e seus compostos arsenicais tar Adquirida (L85.1) (X49.-; Z57.4 e Z57.5) (Quadro 1)

Úlcera Crônica da Pele, - Cromo e seus compostos tóxicos (Z57.5) não classificada em outra (Quadro 10)

parte (L98.4) - Enzimas de origem animal, vegetal ou bacteriana (Z57.8) (Quadro 27)

Geladura (Frostbite) Su- . Cloreto de etila (anestésico local) (W93.-; perficial (T33): Eritema Z57.6) (Quadro 13)

Pérnio

- Frio (X31.-; W93.-; Z57.6) (Quadro 27)

Geladura (Frostbite) com - Cloreto de etila (anestésico local) (W93.-; Necrose de Tecidos (T34) Z57.6) (Quadro 13)

Frio (X31.-; W93.-; Z57.6) (Quadro 27) 


\begin{tabular}{|c|c|}
\hline \multicolumn{2}{|c|}{$\begin{array}{l}\text { DOENCAS DO SISTEMA OSTEOMUSCULAR E DO TECIDO CONJUNTIVO, } \\
\text { RELACIONADAS COM O TRABALHO } \\
\text { (Grupo XIII do }(I D-10 \text { ) }\end{array}$} \\
\hline Doenças & $\begin{array}{c}\text { Agentes etiológicos ou fatores de risco } \\
\text { de natureza ocupacional }\end{array}$ \\
\hline $\begin{array}{l}\text { Artrite Reumatóide asso- } \\
\text { ciada a Pneumoconiose } \\
\text { dos Trabalhadores do Car- } \\
\text { vão (J60.-): "Síndrbme de } \\
\text { Caplan"(M05.3) }\end{array}$ & $\begin{array}{l}\text { - Exposição ocupacional a poeiras de car- } \\
\text { vão mineral (Z57.2) } \\
\text { - Exposição ocupacional a poeiras de sílica } \\
\text { livre (Z57.2)(Quadro 18)l }\end{array}$ \\
\hline $\begin{array}{l}\text { Gota induzida pelo chum- } \\
\text { bo (M10.1) }\end{array}$ & $\begin{array}{l}\text { - Chumbo ou seus compostos tóxicos } \\
\text { (X49.-; Z57.5) (Quadro 8) }\end{array}$ \\
\hline Outras Artroses (M19.-) & $\begin{array}{l}\text { - Posições forçadas e gestos repetitivos } \\
\text { (Z57.8) }\end{array}$ \\
\hline $\begin{array}{l}\text { Outros transtornos arti- } \\
\text { culares não classificados } \\
\text { em outra parte: Dor Arti- } \\
\text { cular (M25.5) }\end{array}$ & $\begin{array}{l}\text { - Posições forçadas e gestos repetitivos } \\
\text { (Z57.8) } \\
\text { - Vibrações localizadas (W43.-; Z57.7) } \\
\text { (Quadro 22) }\end{array}$ \\
\hline $\begin{array}{l}\text { Síndrome Cervicobra- } \\
\text { quial (M53.1) }\end{array}$ & $\begin{array}{l}\text { - Posições forçadas e gestos repetitivos } \\
\text { (Z57.8) } \\
\text { - Vibraçס̃es localizadas (W43.-; Z57.7) } \\
\text { (Quadro 22) }\end{array}$ \\
\hline $\begin{array}{l}\text { Dorsalgia (M54.-): Cer- } \\
\text { vicalgia (M54.2); Ciática } \\
\text { (M54.3); Lumbago com } \\
\text { Ciática (M54.4) }\end{array}$ & $\begin{array}{l}\text { - Posições forçadas e gestos repetitivos } \\
\text { (Z57.8) } \\
\text {-Ritmo de trabalho penoso (Z56.3) } \\
\text { - Condições difíceis de trabalho (Z56.5) }\end{array}$ \\
\hline $\begin{array}{l}\text { Sinovitese Tenossinovites } \\
\text { (M65.-): Dedo em Gatilho } \\
\text { (M65.3); Tenossinovite do } \\
\text { Estiloide Radial (De } \\
\text { Quervain) (M65.4); Ou- } \\
\text { tras Sinovites e Tenossino- } \\
\text { vites (M65.8); Sinovites e } \\
\text { Tetlossinovites, não es- } \\
\text { pecificadas (M65.9) }\end{array}$ & $\begin{array}{l}\text { - Posições forçadas e gestos repetitivos } \\
\text { (Z57.8) } \\
\text { - Ritmo de trabalho penoso (Z56.3) } \\
\text { - Condições difíceis de trabalho (Z56.5) }\end{array}$ \\
\hline $\begin{array}{l}\text { Transtornos dos tecidos } \\
\text { moles relacionados como } \\
\text { uso, o uso excessivo e a } \\
\text { pressão, de origem ocu- } \\
\text { pacional (M70.-): Sinovite } \\
\text { CrepitanteCrônica da mão } \\
\text { e do punho (M70.0); } \\
\text { Bursite da Mão (M70.1); } \\
\text { Bursite do Olécrano } \\
\text { (M70.2); Outras Bursites } \\
\text { do Cotovelo (M70.3); } \\
\text { Outras Bursites. Pré- } \\
\text { rotulianas (M70.4); Ou- } \\
\text { tras Bursites do Joelho } \\
\text { (M70.5); Outros trans- } \\
\text { tornos dos tecidos moles } \\
\text { relacionados com o uso, } \\
\text { o uso excessivo e a pres- }\end{array}$ & $\begin{array}{l}\text { - Posições forçadas e gestos repetitivos } \\
\text { (Z57.8) } \\
\text { - Ritmo de trabalho penoso (Z56.3) } \\
\text { - Condições difíceis de trabalho (Z56.5) }\end{array}$ \\
\hline
\end{tabular}

são (M70.8); Transtorno

não especificado dos te-

cidos moles, relacionados

com o uso, o uso exces-

sivo e a pressão (M70.9)

Fibromatose da Fascia - Posições forçadas e gestos repetitivos Palmar: "Contratura ou (Z57.8)

Moléstia de Dupuytren" - Vibrações localizadas (W43.-; Z57.7) (M72.0)

Lesões do Ombro(M75.-): - Posições forçadas e gestos repetitivos Capsulite Adesiva do (Z57.8)

Ombro (Ombro Congela- - Ritmo de trabalho penoso (Z56)

do, Periartrite do Ombro) - Vibrações localizadas (W43.-; Z57.7) (M75.0); Síndrome do (Quadro 22)

Manguito Rotatório ou

Síndrome do Supraes-

pinhoso (M75.1); Ten-

dinite Bicipital (M75.2);

Tendinite Calcificante do

Ombro (M75.3); Bursite

do Ombro (M75.5); Ou-

tras Lesões do Ombro

(M75.8); Lesões do Om-

bro, não especificadas

(M75.9)

Outras entesopatias - Posições forçadas e gestos repetitivos (M77.-): Epicondilite (Z57.8)

Medial (M77.0); Epicon- - Vibrações localizadas (W43.-; Z57.7) dilite lateral ("Cotovelo (Quadro 22)

de Tenista"); Mialgia (M79.1)

Outros transtornos espe- - Posições forçadas e gestos repetitivos cificados dos tecidos mo- $(\mathrm{Z} 57.8)$

les (M79.8) (Quadro 22)

Osteomalácia do Adulto . Cádmio ou seus compostos (X49.-)(Quainduzida por drogas dro 6)

(M83.5) de Fósforo) (X49.-; Z57.5) (Quadro 12)

Fluorose do Esqueleto - Flúor e seus compostos tóxicos (X49.-(M85.1)

Z57.5) (Quadro 11)

Osteonecrose (M87.-): - Fósforo e seus compostos (Sesquissulfeto Osteonecrose devida a de Fósforo) (X49.-; Z57.5) (Quadro 12) drogas (M87.1); Outras - Vibrações localizadas (W43.-; Z57.7) Osteonecroses secundá- (Quadro 22)

rias (M87.3)

Ostéolise (M89.5) (de -Cloreto de Vinila (X49.-;Z57.5)(Quadro 13) falanges distais de quirodáctilos)

Osteonecrose no "Mal - "Ar Comprimido" (W94.-; Z57.8) (Quados Caixões" (M90.3) dro 23)

Doença de Kienböck do - Vibrações localizadas (W43.-; Z57.7) 
Adulto (Osteo-condrose (Quadro 22)

do Adulto do Semilunar

do Carpo) (M93.1) e ou-

tras Osteocondropatias

especificadas (M93.8)

\begin{tabular}{ll}
\hline \multicolumn{1}{c}{ DOENÇAS DO SISTEMA GÊNITO-URINÁRIO RELACIONADAS COM O } \\
TRABALHO (Grupo XIV do CID-10)
\end{tabular}

TRAUMATISMOS, ENVENENAMENTOS E ALGUMAS OUTRAS

CONSEQÜÊNCIAS DE CAUSAS EXTERNAS, RELACIONADOS COM 0 TRABALHO (Grupo XIX da CID-10)

Agentes etiológicos ou fatores de risco
de natureza ocupacional

Efeitos tóxicos de Sol- · Exposição ocupacional a agentes tóxicos ventes Orgânicos (T52.): em outras indústrias (Z57.5)

Álcoóis (T51.8) e Ceto-

nas (T52.4); Benzeno, Tetracloroetileno (T53.3); Dicloroetano Tolueno e Xileno (T52.1 (T53.4); Clorofluorcarbonos (T53.5); Oue T52.2); Derivados tros derivados halogenados de halogenados dos Hidro- hidrocarbonetos alifáticos (T53.6); Outros carbonetos Alifáticos e derivados halogenados de hidrocarbonetos Aromáticos (T53): Te- aromáticos(T53.7); Derivados halogenados tracloreto de Carbono de hidrocarbonetos alifáticos e aromáticos,
(T53.0); Clorofórmio não especificados (T53.9); Sulfeto de Car(T53.1); Tricloroetileno bono(T65.4) (T53.2);

Efeito tóxico de Substân- ·Exposição ocupacional a agentes tóxicos cias Corrosivas (T54): em outras indústrias (Z57.5)

Fenol e homólogos do fenol (T54.0); Flúor e seus compostos (T65.8);

Selênio e seus compostos

(T56.8); Outros compostos orgânicos corrosivos (T54.1); Ácidos corrosivos e substâncias ácidas similares (T54.2); Álcalis cáusticos e substâncias alcalinas similares (T54.3); Efeito tóxico de substância corrosiva, não especificada (T54.9).

Efeito tóxico de Metais Exposição ocupacional a agentes tóxicos (T56): Arsênico e seus em outras indústrias (Z57.5) compostos (T57.0); Cádmio e seus compostos (T56.3); Chumbo e seus compostos (T56.0); Cromo e seus compostos (T56.2); Manganês e seus compostos (T57.2); Mercúrio e seus compostos (T56.1); Outros metais (T56.8); Metal, não especificado (T56.9).

Asfixiantes Químicos ·Exposição ocupacional a agentes tóxicos (T57-59): Monóxido de em outras indústrias (Z57.5)

Carbono (T58); Ácido

cianídrico e cianetos

(T57.3); Sulfeto de hi-

drogênio T59.6); Aminas

aromáticas e seus deriva-

$\operatorname{dos}(\mathrm{T} 65.3)$

Praguicidas (Pesticidas, · Exposição ocupacional a agentes tóxicos "Agrotóxicos") (T60): naAgricultura (Z57.4)

Organofosforados

Carbamatos (T60.0)

Halogenados (T60.1)

Outros praguicidas

(T60.2)

Efeitos da Pressão do Are - Exposição ocupacional a pressões atmosda Pressão da Água(T70): féricas anormais (W94.-; Z57.8)

Barotrauma Otítico (T

70.0); Barotrauma Sinusal

(T70.1); Doença

Descompressiva ("Mal

dos Caixões") (T70.3)

Outros efeitos da pressão

do ar e da água (T70.8) 


\begin{abstract}
ANEXO 12
INSTITUTO NACIONAL

DO SEGURO SOCIAL - INSS

DIRETORIA COLEGIADA

Resolução INSS/DC/ n 010, de 23 de dezembro de 1999.
\end{abstract}

Assunto: Aprova os Protocolos Médicos, com alterações realizadas pela Coordenação Geral de Benefícios por Incapacidade da Diretoria de Benefícios e dá outras providencias.

\title{
FUNDAMENTAÇÃO LEGAL:
}

Lei $n^{0} 8.213$, de 24 de julho de 1991, e Decreto $n^{0} 3.048$, de 06 de maio de1991.

A DIRETORIA COLEGIADA DO INSTITUTO NACIONAL DO SEGURO SOCIAL - INSS, no uso da competência que lhe confere o inciso III, artigo 11 do Anexo 1, da Estrutura Regimental do INSS, aprovada pelo Decreto $\mathrm{n}^{0} 3.081$, de $10 \mathrm{de}$ junho de 1999,

CONSIDRANDO os estados técnicos realizados, relativamente a lista $\mathrm{B}$, do Anexo II, do Regulamento da Previdência Social, conforme previsto no art. 20 da lei 8.213/91,

CONSIDERANDO a avaliação técnica procedida pela área de perícias medicas do INSS,

\section{RESOLVE:}

1 - Aprovar os Protocolos Médicos, com alterações realizadas pela Coordenação Geral de Benefícios por Incapacidade, da Diretoria de Benefícios, deste Instituto, conforme Anexos, contendo os seguintes grupos:

Anexo I - Grupo 1 - Doenças Infecciosas e Parasitárias que podem estar relacionadas com o trabalho;

Anexo II - Grupo 2- Neoplasias (Tumores) que podem estar relacionadas com o trabalho;

Anexo III - Grupo 3 - Doenças do Sangue e dos Órgãos Hematopoiéticos que podem estar relacionados com o trabalho

Anexo IV - Grupo 4- Doenças Endócrinas, Nutricionais e Metabólicas que podem estar relacionadas com o trabalho;

Anexo V - Grupo 5 - Transtornos mentais e do comportamento que podem estar relacionados com o trabalho;

Anexo VI - Grupo 7 - Doenças do olho e anexos que podem estar relacionadas com o trabalho. 
Anexo VII - Grupo 9- Doenças do sistema circulatório que podem estar relacionadas com o trabalho;

Anexo VIII - Grupo 10 - Doenças do aparelho respiratório que podem estar relacionadas com o trabalho;

Anexo X - Grupo 11 - Doenças do aparelho digestivo que podem ser relacionadas com o trabalho;

Anexo XI - Grupo 12- Doenças da pele do tecido subcutâneo que podem estar relacionadas com o trabalho;

Anexo XII - Grupo 13 - Doenças osteomusculares do tecido conjuntivo que podem estar relacionadas com o trabalho, e

Anexo XIII - Grupo 14 - Doenças do sistema Gênito-Urinário que pode estar relacionado com o trabalho.

2 - Considerar aprovadas, permanecendo válidas as seguintes Normas Técnicas, aprovadas anteriormente, por Atos do Diretor do Seguro Social, da estrutura anterior do INSS:

2.1 - Ordem de Serviço (INSS/DSS no 606, de 05 de agosto de 1998 - Norma Técnica sobre Distúrbios Osteomusculares Relacionados ao Trabalho - DORT, publicada no DOU n ${ }^{0} 159$, de 20/08/98, Seção 1, pág. 70/79.

2.2- Ordem de Serviço INSS/DSS n ${ }^{0} 607$, de 05 de agosto de 1998 - Normas Técnicas sobre Intoxicação Ocupacional de

Benzeno, publicada no DOU n ${ }^{0} 158$, de 19/ 08/1998, Seção 1, pág. 38/44.

2.3 — Ordem de Serviço/INSS/DSS n ${ }^{0}$ 608, de 05 de agosto de 1998 - Normas Técnicas sobre Perda Auditiva Neurosensorial por Exposição Continuada a Níveis Elevados de Pressão Sonoro de Origem Ocupacional, publicada no DOU $n^{0} 158$, de 19/08/98, Seção 1 pag. 44/53, e

2.4 - Ordem de Serviço/INSS/DSS n ${ }^{0}$ 609, de 19 de agosto de 1998- Norma Técnica sobre Pneumoconioses, publicadas no DOU $n^{0} 159$, de 19/08/98, Seção 1, pág. 53/60.

3 - Esta Resolução entra em vigor na data de sua publicação e revoga as disposições em contrário.

CRÉSIO DE MATOS ROLIM

Diretor-Presidente

MARCOS MAIA JUNIOR

Procurador-Geral

PAULO ROBERTO TANNUS FREITAS

Diretor de Administração

SEBASTIÂO FAUSTINO DE PAULA

Diretor de Benefícios

LU]Z ALBERTO LAZINHO

Diretor de Arrecadação 


\section{DOENÇAS INFECCIOSAS E PARASITÁRIAS QUE PODEM ESTAR RELACIONADAS COM O TRABALHO}

I. Tuberculose (A15-19.-)

II. Carbúnculo (A22.-)

III. Brucelose (A23.-)

IV. Leptospirose (A27.-)

V. Tétano (Do Adulto) (A35.-)

VI. Psitacose, Ornitose (Doença dos Tratadores de Aves) (A70.-)

VII. Dengue (Dengue Clássico) (A90.-)

VIII. Febre Amarela (A95.-)

IX. Hepatite Viral (B15-B19.-)

X. Doenças pelo Vírus da Imunodeficiência Humana (HIV) (B20-B24.-)

XI. Dermatofitose e Outras Micoses (B35-B36.-)

XII. Candidíase da Pele e das Unhas (B37.2)

XIII. Paracoccidiodomicose (Blastomicose Sul Americana, Blastomicose

Brasileira, Doença de Lutz) (B41.-)

XIV.Malária (Relacionada com o Trabalho)(B50-B54.-)

XV. Leishmaniose Cutânea e Leishmaniose Cutâneo-Mucosa (B55.1 e B55.2)

\section{DOENÇAS DO APARELHO DIGESTIVO QUE PODEM SER RELACIONADAS COM O TRABALHO}

I. Erosão Dentária (K03.2)

II. Alterações Pós-Eruptivas da Cor dos Tecidos Duros dos Dentes (Dentes Manchados) (K03.7)

III. Gengivite Crônica (K05.1)

IV. Estomatite Ulcerosa Crônica (KI2.1)

V. Gastroenterite e Colite Tóxicas (K52. 1)

VI. Cólica do Chumbo (K59.8)

VII. Doença Hepática Tóxica (K71.-)

VIII. Hipertensão Portal (K76.6)

PROTOCOLO DE PROCEDIMENTOS MÉDICO-PERICIAIS N. 11.1

Doença: “EROSÃO DENTÁRIA” (Relacionada com o Trabalho)

Código CID-10: K03.2

Versão de 6/99

SEÇÃO 1

\section{I - DEFINIÇÃO DA DOENÇA E CRITERIOS PARA SEU DIAGNÓSTICO}

Erosão dentária é a destruição do tecido dentário observada em trabalhadores expostos a alguns agentes ocupacionais. 
O quadro é de destruição dentária partindo da superfície incisal para a cervical, com aspecto de polimento regular. Quando o esmalte é destruído, a dentina é atacada podendo atingir a polpa dental, com aparecimento de dor. Pode ainda haver invasão bacteriana e conseqüente formação de abscessos.

\section{II - FATORES ETIOLÓGICOS (GERAIS) E IDENTIFICAÇÃO DOS PRINCIPAIS "AGENTES PATOGÊNICOS"}

Entre as causas não ocupacionais de erosão dentária, destacam-se o bruxismo e hábitos de morder objetos ou superfícies duras, que podem produzir abrasão e outros danos.

A exposição ocupacional a névoas de fluoretos e outras névoas ácidos, entre elas as de ácido crômico, ácido tartárico, ácido nítrico e ácido sulfúrico pode cursar com o desenvolvimento de erosões dentários. Entre nós, os trabalhadores mais acometidos encontram-se nas galvanoplastias (exposição a névoas de ácido crômico) e em fábricas de baterias (exposição a névoas de ácido sulfúrico, na operação de carga elétrica da bateria). Em fábrica de fertilizantes e outros trabalhos com rocha fosfática, o achado de erosão dentária está associado à exposição a fluoretos.

Em trabalhadores expostos, as erosões dentárias devem ser consideradas como doenças relacionadas com o trabalho do Grupo 1 da Classificação de Schilling, isto é, "doenças profissionais", em que o "trabalho" ou a "ocupação" constituem causa necessária. Se não ocorresse a exposição ocupacional, seria K03.2 improvável que esta doença ocorresse.

III - PARÂMETROS QUE TÊM SIDO UTILIZADOS PARA AVALIAR, SOB O PONTO DE VISTA ESTRITAMENTE MÉDICO, A NATUREZA E O GRAU DA "DEFICIÊNCIA" OU "DISFUNÇÃO" EVENTUALMENTE PRODUZIDOS POR ESTA DOENÇA

"Deficiência"-Redução permanente e irreversível em grau variado de uma função ou sistema que não impede a execução de atos funcionais. "Disfunção"- qualquer perda ou anormalidade da estrutura ou função psicológica, fisiológica ou anatômica, podendo ser temporária ou permanente, não contribuindo necessariamente para a execução de atos funcionais.

A avaliação médica da deficiência - se e quando necessária - está justificada pela constatação de que o diagnóstico de "erosão dentária", por si só é insuficiente para dar uma idéia da gravidade, das repercussões sobre o desempenho do paciente, e mesmo do prognóstico.

\section{IV - PROCEDIMENTOS MEDICOS PARA O ESTABELECIMENTO DO NEXO CAUSAL}

Recomenda-se, incluir nos procedimentos e no raciocínio médico-pericial, a resposta a dez questões essenciais, a saber:

- Natureza da exposição: o "agente patogênico" é claramente identificável pela história ocupacional e/ou pelas informações colhidas no local de trabalho e/ou de fontes idôneas familiarizadas com o ambiente ou local de trabalho do Segurado? 
- "Especificidade" da relação causal e "força" da associação causal: o "agente patogênico" ou o "fator de risco" podem estar pesando de forma importante entre os fatores causais da doença?

- Tipo de relação causal com o trabalho: o trabalho é causa necessária (Tipo 1)? Fator de risco contributivo de doença de etiologia multicausal (Tipo II)? Fator desencadeante ou agravante de doença pré-existente (Tipo III)?

- No caso de doenças relacionadas com o trabalho, do tipo II, foram as outras causas gerais, não ocupacionais, devidamente analisadas e, no caso concreto, excluídas ou colocadas em hierarquia inferior às causas de natureza ocupacional?

- Grau ou intensidade da exposição: é ele compatível com a produção da doença?

- Tempo de exposição: é ele suficiente para produzir a doença?

- Tempo de latência: é ele suficiente para que a doença se desenvolva e apareça?

- Há o registro do "estado anterior" do trabalhador segurado?

- O conhecimento do "estado anterior" favorece o estabelecimento do nexo causal entre o "estado atual" e o trabalho?

- Existem outras evidências epidemiológicas que reforçam a hipótese de relação causal entre a doença e o trabalho presente ou pregresso do segurado?

A resposta positiva à maioria destas questões irá conduzir o raciocínio na direção do reconhecimento técnico da relação causal entre a doença e o trabalho.

\section{SEÇÃO II}

\section{I - AVALIAÇÃO DA INCAPACIDADE LABORATIVA}

"Incapacidade" É a impossibilidade do desempenho das funções específicas de uma atividade ou ocupação, em consequiência de alterações morfopsicofisiológicas provocadas por doença ou acidente. $\mathrm{O}$ risco de vida para si ou para terceiros, ou de agravamento que a permanência em atividade possa acarretar, está implicitamente incluído no conceito de incapacidade, desde que palpável e indiscutível. Portanto, para o pronunciamento médico-pericial sobre a existência de "incapacidade laborativa" do segurado, é imprescindível considerar as seguintes informações:

- Diagnóstico da doença

- Tipo de atividade ou profissão e suas exigências

- Dispositivos legais pertinentes

- Viabilidade de reabilitação profissional

\section{II - PROCEDIMENTOS MÉDICO-PERICIAIS PARA O} "RECONHECIMENTO TÉCNICO DO NEXO CAUSAL ENTRE A DOENÇA E O TRABALHO" (Art. 337 Decreto 3048/99)

Para o reconhecimento técnico do nexo causal a Perícia Médica deve considerar os seguintes elementos:

- A história clínica e ocupacional, decisiva em qualquer diagnóstico elou investigação de nexo causal;

- O estudo do local de trabalho;

- O estudo da organização do trabalho;

- Os dados epidemiológicos;

- A ocorrência de quadro clínico incapacitante em trabalhador exposto a condições agressivas; 
- A identificação de riscos físicos, químicos, biológicos, mecânicos, ergonômicos, e outros;

PROTOCOLO DE PROCEDIMENTOS MÉDICO-PERICIAIS N ${ }^{0}$. 11. II Doença: “ALTERAÇÕES PÓS-ERUPTIVAS DA COR DOS TECIDOS DUROS DOS DENTES" ("Dentes Manchados") (Relacionadas com o Trabalho) Código CID-10: K03.7 Versão de 6/99

\section{SEÇÃO 1 \\ I - DEFINIÇÃO DA DOENÇA E CRITÉRIOS PARA SEU \\ DIAGNÓSTICO}

Alterações da cor dos dentes constituem achado relativamente comum, que pode ser facilmente observado, sem procedimentos propedêuticos mais complexos.

\section{II- FATORES ETIOLÓGICOS (GERAIS) E IDENTIFICAÇÃO DOS PRINCIPAIS “AGENTES PATOGENICOS”}

Nos adultos, a principal causa de manchas dentárias é o tabagismo, responsável pelo escurecimento, de tom marrom amarelado. O envelhecimento "normal" também provoca o escurecimento dos dentes, ainda que lentamente. Causa comum de escurecimento dentário é a necrose da polpa, ou cáries profundas que a atingem, ou a absorção de hemossiderina pela polpa, após trauma.

As manchas dentárias de origem ocupacional podem, também, ocorrer em trabalhadores expostos a névoas de sais metálicos e seus compostos. A exposição ocupacional ao cádmio produz manchas de cor amarelo-ouro; a exposição ocupacional ao cobre produz manchas verde escuro; a exposição ocupacional ao níquel produz manchas dentárias de cor esverdeada ou preta; a exposição ocupacional à prata produz manchas cinza-acastanhadas ou marrons.

Em trabalhadores expostos a estes produtos químicos, as manchas dentárias, com as características de cor e história de desenvolvimento pós-exposição ocupacional, podem ser consideradas como doenças relacionadas com o trabalho do Grupo I da Classificação de Schilling, isto é, "doenças profissionais", em que o "trabalho" ou a "ocupação" constituem causa necessária. Se não ocorresse a exposição ocupacional, seria improvável que esta doença, com as características descritas, ocorresse.

III - PARÂMETROS QUE TÊM SIDO UTILIZADOS PARA AVALIAR, SOB O PONTO DE VISTA ESTRITAMENTE MÉDICO, A NATUREZA E O GRAU DA “DEFICIÊNCIA" OU "DISFUNÇAO" EVENTUALMENTE PRODUZIDOS POR ESTA DOENÇA

"Deficiência"-Redução permanente e irreversível em grau variado de uma função ou sistema que não impede a execução de atos funcionais. "Disfunção"- qualquer perda ou anormalidade da estrutura ou função psicológica, fisiológica ou anatômica, podendo ser temporária ou permanente, não contribuindo necessariamente para a execução de atos funcionais. 
A avaliação médica da deficiência - se e quando necessária - está justificada pela constatação de que o diagnóstico de "dentes manchados", por si só é insuficiente para dar uma idéia da gravidade, das repercussões sobre o desempenho do paciente, e mesmo do prognóstico.

Contudo, no caso das "doenças da cavidade oral", os critérios adotados pela AMA, publicados em seus Guides, não contemplam qualquer disfunção ou deficiência de carácter mais perene, que justifique a definição de parâmetros para a avaliação e o estadiamento, como ingrediente para avaliar eventual incapacidade.

\section{IV - PROCEDIMENTOS MÉDICOS PARA O ESTABELECIMENTO DO NEXO CAUSAL}

Recomenda-se, incluir nos procedimentos e no raciocínio médico-pericial, a resposta a dez questões essenciais, a saber:

- Natureza da exposição: o "agente patogênico" é claramente identificável pela história ocupacional e/ou pelas informações colhidas no local de trabalho e/ou de fontes idôneas familiarizadas com o ambiente ou local de trabalho do Segurado?

- "Especificidade" da relação causal e "força" da associação causal: o "agente patogênico" ou o "fator de risco" podem estar pesando de forma importante entre os fatores causais da doença?

- $\quad$ Tipo de relação causal com o trabalho: o trabalho é causa necessária (Tipo 1)? Fator de risco contributivo de doença de etiologia multicausal (Tipo II)? Fator desencadeante ou agravante de doença pré-existente (Tipo III)?

- $\quad$ No caso de doenças relacionadas com o trabalho, do tipo II, foram as outras causas gerais, não ocupacionais, devidamente analisadas e, no caso concreto, excluídas ou colocadas em hierarquia inferior às causas de natureza ocupacional?

- $\quad$ Grau ou intensidade da exposição: é ele compatível com a produção da doença?

- $\quad$ Tempo de exposição: é ele suficiente para produzir a doença?

- $\quad$ Tempo de latência: é ele suficiente para que a doença se desenvolva e apareça?

- Há o registro do "estado anterior" do trabalhador segurado?

- O conhecimento do "estado anterior" favorece o estabelecimento do nexo causal entre o "estado atual" e o trabalho?

- Existem outras evidências epidemiológicas que reforçam a hipótese de relação causal entre a doença e o trabalho presente ou pregresso do segurado?

A resposta positiva à maioria destas questões irá conduzir o raciocínio na direção do reconhecimento técnico da relação causal entre a doença e o trabalho.

SEÇAO II

1- AVALIAÇÃO DA INCAPACIDADE LABORATIVA 
"Incapacidade" É a impossibilidade do desempenho das funções específicas de uma atividade ou ocupação, em consequencia de alterações morfopsicofisiológicas provocadas por doença ou acidente. O risco de vida para si ou para terceiros, ou de agravamento que a permanência em atividade possa acarretar, esta implicitamente incluído no conceito de incapacidade, desde que palpável e indiscutível.

Portanto, para o pronunciamento médico-pericial sobre a existência de "incapacidade laborativa" do segurado, é imprescindível considerar as seguintes informações:

- Diagnóstico da doença

- Tipo de atividade ou profissão e suas exigências

- Dispositivos legais pertinentes

- Viabilidade de reabilitação profissional

II - PROCEDIMENTOS MÉDICOPERICIAIS PARA O "RECONHECIMENTO TÉCNICO DO NEXO CAUSAL ENTRE A DOENÇA E O TRABALHO” (Art. 337 Decreto

3048/99)

Para o reconhecimento técnico do nexo causal a Perícia Médica deve considerar os seguintes elementos:

- A história clínica e ocupacional, decisiva em qualquer diagnóstico elou investigação de nexo causal;

- O estudo da local de trabalho;

- O estudo da organização do trabalho;

- Os dados epidemiológicos;

- A ocorrência de quadro clínico incapacitante em trabalhador exposto a condições agressivas;

- A identificação de riscos físicos, químicos, biológicos, mecânicos, ergonômicos, e outros;

\section{OBSERVAÇÕES ADICIONAIS ÚTEIS PARA OS PROCEDIMENTOS MÉDICOPERICIAIS}

Leitura Recomendada:

ARAUJO, M.E. - Estudo da prevalência das manifestações bucais decorrentes de agentes químicos no processo de galvanoplastia: sua importância para a área de saúde bucal do trabalhador. São Paulo, 1998. [Tese de Doutorado, Faculdade de Odontologia da USP].

PROTOCOLO DE PROCEDIMENTOS MÉDICO-PERICIAIS N0 $\mathbf{N}^{0}$ 11.III Doença: "GENGIVITE CRONICA" (Relacionada com o Trabalho) Código CID- 10: K05.1

Versão de 6/99

SEÇÃO 1

I - DEFINIÇÃO DA DOENÇA E CRITÉRIOS PARA SEU DIAGNÓSTICO 
Gengivite é a inflamação da gengiva, caracterizada por entumescimento, vermelhidão, alteração dos contornos normais, exsudato e sangramento. Nos casos complicados por infecção secundária, pode haver dor, halitose, sangramento e piorréia.

\section{II - FATORES ETIOLÓGICOS (GERAIS) E IDENTIFICAÇÃO DOS PRINCIPAIS “AGENTES PATOGENICOS”}

A principal causa de gengivite é a doença periodôntica, associada à falta de higiene bucal. Outros fatores locais são a má oclusão dental, cálculos dentários, falta de restauração dentária e xerostomia. Bactérias - predominantemente anaeróbias, espiroquetas e gram-negativas - estão comumente presentes.

A gengivite ocorre, também, na puberdade, durante a menstruação e na gravidez, aparentemente associada a alterações hormonais. $\mathrm{O}$ uso de contraceptivos orais pode exacerbar quadros de gengivite. Gengivite também pode ser um sinal precoce de doenças sistêmicas, tais como o herpes simples, hipovitaminoses, alterações leucopênicas, reações alérgicas, diabetes, ou doenças consuptivas, como a AIDS, por exemplo.

Outrossim, a exposição ocupacional a névoas de fluoretos ou seus compostos tóxicos e ao mercúrio está relacionada com o desenvolvimento de gengivite crônica. A gengivite causada pelo mercúrio é o quadro mais típico e grave em Patologia do Trabalho.

Outras patologias raras que podem simular a gengivite subaguda ou crônica são o eritema multiforme, o líquen plano, o penfigóide e o pênfigo.

Em trabalhadores expostos, a gengivite crônica, excluídas outras causas subjacentes, pode ser considerada como doença relacionada com o trabalho do Grupo II da Classificação de Schilling, posto que o "trabalho" ou "ocupação" podem constituir-se em fator de risco contributivo, adicional, a doença de etiologia multicausal.

III- PARÂMETROS QUE TÊM SIDO UTILIZADOS PARA AVALIAR, SOB O PONTO DE VISTA ESTRITAMENTE MÉDICO, A NATUREZA E O GRAU DA “DEFICIÊNCIA" OU “DISFUNÇÃO” EVENTUALMENTE PRODUZIDOS POR ESTA DOENÇA

"Deficiência"- Redução permanente e irreversível em grau variado de uma função ou sistema que não impede a execução de atos funcionais. "Disfunção"- qualquer perda ou anormalidade da estrutura ou função psicológica, fisiológica ou anatômica, podendo ser temporária ou permanente, não contribuindo necessariamente para a execução de atos K05.1 funcionais.

A avaliação médica da deficiência - se e quando necessária - está justificada pela constatação de que o diagnóstico de "gengivite crônica", por si só é insuficiente para dar uma idéia da gravidade, das repercussões sobre o desempenho do paciente, e mesmo do prognóstico.

Contudo, no caso das "doenças da cavidade oral", os critérios adotados pela AMA, publicados em seus Guides, não contemplam qualquer disfunção ou deficiência de carácter mais perene, que justifique a definição de parâmetros para a avaliação e o estadiamento, como ingrediente para avaliar eventual incapacidade. 


\section{IV - PROCEDIMENTOS MEDICOS PARA O ESTABELECIMENTO DO} NEXO CAUSAL

Recomenda-se, incluir nos procedimentos e no raciocínio médico-pericial, a resposta a dez questões essenciais, a saber:

- Natureza da exposição: o "agente patogênico" é claramente identificável pela história ocupacional e/ou pelas informações colhidas no local de trabalho e/ou de fontes idôneas familiarizadas com o ambiente ou local de trabalho do Segurado?

- "Especificidade" da relação causal e "força" da associação causal: o "agente patogênico" ou o "fator de risco" podem estar pesando de forma importante entre os fatores causais da doença?

- Tipo de relação causal como trabalho: o trabalho é causa necessária (Tipo 1)? Fator de risco contributivo de doença de Etiologia multicausal (Tipo II)? Fator desencadeante ou agravante de doença pré-existente (Tipo III)?

- No caso de doenças relacionadas com o trabalho, do tipo II, foram as outras causas gerais, não ocupacionais, devidamente analisadas e, no caso concreto, excluídas ou colocadas em hierarquia inferior às causas de natureza ocupacional?

- Grau ou intensidade da exposição: é ele compatível com a produção da doença?

- Tempo de exposição: é ele suficiente para produzir a doença?

- Tempo de latência: é ele suficiente para que a doença se desenvolva e apareça?

- Há o registro do "estado anterior" do trabalhador segurado?

- O conhecimento do "estado anterior" favorece o estabelecimento do nexo causal entre o "estado atual" e o trabalho?

- Existem outras evidências epidemiológicas que reforçam a hipótese de relação causal entre a doença e o trabalho presente ou pregresso do segurado?

A resposta positiva à maioria destas questões irá conduzir o raciocínio na direção do reconhecimento técnico da relação causal entre a doença e o trabalho.

\section{SEÇÃO II}

1- AVALIAÇAO DA INCAPACIDADE LABORATIVA

"Incapacidade" É a impossibilidade do desempenho das funções específicas de uma atividade ou ocupação, em conseqüência de alterações morfopsicofisiológicas provocadas por doença ou acidente. O risco de vida para si ou para terceiros, ou de agravamento que a permanência em atividade possa acarretar, está implicitamente incluído no conceito de incapacidade, desde que palpável e indiscutível.

Portanto, para o pronunciamento médico-pericial sobre a existência de "incapacidade laborativa" do segurado, é imprescindível considerar as seguintes informações:

- Diagnóstico da doença

- Tipo de atividade ou profissão e suas exigências

- Dispositivos legais pertinentes

- Viabilidade de reabilitação profissional

II - PROCEDIMENTOS MÉDICO-PERICIAIS PARA O "RECONHECIMENTO TECNICO DO NEXO CAUSAL ENTRE A DOENÇA E O TRABALHO” (Art. 337 Decreto 3048/99) 
Para o reconhecimento técnico do nexo causal a Perícia Médica deve considerar os seguintes elementos:

- A história clínica e ocupacional, decisiva em qualquer diagnóstico elou investigação de nexo causal;

- O estudo do local de trabalho;

- O estudo da organização do trabalho;

- Os dados epidemiológicos;

- A ocorrência de quadro clínico incapacitante em trabalhador exposto a condições agressivas;

- A identificação de riscos físicos, químicos, biológicos, mecânicos, ergonômicos, e outros;

PROTOCOLO DE PROCEDIMENTOS MÉDICO-PERICIAIS No. 11.1V Doença: "ESTOMATITE ULCEROSA CRÔNICA" (Relacionada com o Trabalho)

\section{Código CID- 10: K12.1}

Versão de 6/99

\section{SEÇÃO I}

\section{I - DEFINIÇÃO DA DOENÇA E CRITÉRIOS PARA SEU DIAGNÓSTICO}

Estomatite é inflamação da mucosa oral, devido a fatores locais ou sistêmicos, que podem envolver a mucosa bucal e labial, palato, língua, céu da boca e gengiva.

Estomatite ulcerativa é lesão oral caracterizada por ulcerações rasas da mucosa da cavidade oral. As lesões orais ocasionadas pela exposição ao arsênico e ao bromo geralmente acompanham-se de sinais/sintomas relativos ao sistema respiratório.

A intoxicação por mercúrio pode cursar inicialmente com gengivite, podendo haver desprendimento do epitélio gengival formando úlceras (estomatite). Pode também cursar com periodontite grave, perdas dentárias e osteomielite, edema de glândulas salivares e salivação excessiva.

\section{II - FATORES ETIOLOGICOS (GERAIS) E IDENTIFICAÇÃO DOS PRINCIPAIS “AGENTES PATOGENICOS”}

As causas gerais não ocupacionais de estomatite são muitas, destacando-se as infecções bacterianas (estreptococos, bacilo da tuberculose, espiroqueta da sífilis, a Neisseria gonorrheae, etc.); as infecções virais (principalmente em imunodeprimidos, gengivoestomatites herpéticas agudas, etc.); as infecções fúngicas (candidíase, por exemplo); doenças sistêmicas (escarlatina, pelagra, escorbuto, leucemia, púrpura trombocitopênica, hipovitaminoses, acrodínia, etc.), e causas locais (alimentos quentes, queimaduras por condimentos, dentifrícios, les3es mecânicas por prótese dentárias, etc.).

Em exposições ocupacionais, destacam-se o arsênio, o bromo e o mercúrio (Ver Gengivite). 
Em trabalhadores expostos, a gengivite ulcerosa crônica deve ser considerada como doença relacionada com o trabalho, do Grupo I da Classificação de Schilling, isto é, "doença profissional", em que o "trabalho" ou a "ocupação" constituem causa necessária. Se não ocorresse a exposição ocupacional, seria improvável que esta doença ocorresse.

III - PARÂMETROS QUE TÊM SIDO UTILIZADOS PARA AVALIAR, SOB O PONTO DE VISTA ESTRITAMENTE MÉDICO, A NATUREZA E O GRAU DA "DEFICIÊNCIA" OU "DISFUNÇÃO" EVENTUALMENTE PRODUZIDOS POR ESTA DOENÇA

"Deficiência"- Redução permanente e irreversível em grau variado de uma função ou sistema que não impede a execução de atos funcionais. "Disfunção"- qualquer perda ou anormalidade da estrutura ou função psicológica, fisiológica ou anatômica, podendo ser temporária ou permanente, não contribuindo necessariamente para a execução de atos funcionais.

A avaliação médica da deficiência - se e quando necessária - está justificada pela constatação de que o diagnóstico de "estomatite ulcerosa crônica", por si só é insuficiente para dar uma idéia da gravidade, das repercussões sobre o desempenho do paciente, e mesmo do prognóstico.

Contudo, no caso das "doenças da cavidade oral", os critérios adotados pela AMA, publicados em seus Guides, não contemplam qualquer disfunção ou deficiência de carácter mais perene, que justifique a definição de parâmetros para a avaliação e o estadiamento, como ingrediente para avaliar eventual incapacidade. Outras doenças causadas pelos mesmos agentes patogênicos deverão também ser investigadas.

\section{IV - PROCEDIMENTOS MÉDICOS PARA O ESTABELECIMENTO DO NEXO CAUSAL}

Recomenda-se, incluir nos procedimentos e no raciocínio médico-pericial, a resposta a dez questões essenciais, a saber:

- Natureza da exposição: o "agente patogênico" é claramente identificável pela história ocupacional e/ou pelas informações colhidas no local de trabalho e/ou de fontes idôneas familiarizadas com o ambiente ou local de trabalho do Segurado?

- "Especificidade" da relação causal e "força" da associação causal: o "agente patogênico" ou o "fator de risco" podem estar pesando de forma importante entre os fatores causais da doença?

- Tipo de relação causal com o trabalho: o trabalho é causa necessária (Tipo 1)? Fator de risco contributivo de doença de etiologia multicausal (Tipo II)? Fator desencadeante ou agravante de doença pré-existente (Tipo III)?

- No caso de doenças relacionadas com o trabalho, do tipo II, foram as outras causas gerais, não ocupacionais, devidamente analisadas e, no caso concreto, excluídas ou colocadas em hierarquia inferior às causas de natureza ocupacional?

- Grau ou intensidade da exposição: é ele compatível com a produção da doença?

- Tempo de exposição: é ele suficiente para produzir a doença?

- Tempo de latência: é ele suficiente para que a doença se desenvolva e apareça?

- Há o registro do "estado anterior" do trabalhador segurado? 
- O conhecimento do "estado anterior" favorece o estabelecimento do nexo causal entre o "estado atual" e o trabalho?

- Existem outras evidências epidemiológicas que reforçam a hipótese de relação causal entre a doença e o trabalho presente ou pregresso do segurado?

A resposta positiva à maioria destas questões irá conduzir o raciocínio na direção do reconhecimento técnico da relação causal entre a doença e o trabalho.

\section{SEÇAO II}

1- AVALIAÇÃO DA INCAPACIDADE LABORATIVA

"Incapacidade" É a impossibilidade do desempenho das funções específicas de uma atividade ou ocupação, em conseqüência de alterações morfopsicofisiológicas provocadas por doença ou acidente. O risco de vida para si ou para terceiros, ou de agravamento que a permanência em atividade possa acarretar, está implicitamente incluído no conceito de incapacidade, desde que palpável e indiscutível.

Portanto, para o pronunciamento médico-pericial sobre a existência de "incapacidade laborativa" do segurado, é imprescindível considerar as seguintes informações:

- $\quad$ Diagnóstico da doença

- $\quad$ Tipo de atividade ou profissão e suas exigências

- $\quad$ Dispositivos legais pertinentes

- $\quad$ Viabilidade de reabilitação profissional

II - PROCEDIMENTOS MÉDICOPERICIAIS PARA O "RECONHECIMENTO TÉCNICO DO NEXO CAUSAL ENTRE A DOENÇA E O TRABALHO” (Art. 337 Decreto 3048/99)

Para o reconhecimento técnico do nexo causal a Perícia Médica deve considerar os seguintes elementos:

- A história clínica e ocupacional, decisiva em qualquer diagnóstico elou investigação de nexo causal;

- O estudo do local de trabalho;

- O estudo da organização do trabalho;

- Os dados epidemiológicos;

- A ocorrência de quadro clínico incapacitante em trabalhador exposto a condições agressivas;

- A identificação de riscos físicos, químicos, biológicos, mecânicos, ergonômicos, e outros;

\section{III- OBSERVAÇÕES ADICIONAIS ÚTEIS PARA OS PROCEDIMENTOS MÉDICOPERICIAIS \\ Leitura Recomendada:}

ARAUJO, M.E. - Estudo da prevalência das manifestações bucais decorrentes de agentes químicos no processo de galvanoplastia: sua importância para a área de saúde bucal do trabalhador. São Paulo, 1998. [Tese de Doutorado, Faculdade de Odontologia da USP]. 


\section{REFERÊNCIAS BIBLIOGRÁFICAS ${ }^{1}$}

1. ABEGG, C. Hábitos de higiene bucal de adultos porto-alegrenses. Rev Saúde Públ, v.31, n.6, p.586-593, jun. 1997.

2. ALBORNOZ, S. O que é trabalho. São Paulo: Brasiliense, 1995. 103p.

3. ALVES, C. Trabalho em ambientes hiperbáricos e sua relação com a saúde/doença. In: MENDES, R. Patologia do trabalho. Rio de Janeiro: Atheneu, 1995. Cap. 22. p.573-596.

4. AMERICAN DENTAL ASSOCIATION. Absenteeism and dental disease. J Am Dent Assoc, v.33, p.1154-1155, 1946.

5. AMERICAN DENTAL ASSOCIATION. Committee on economics. Dental service in industry. J Am Dent Assoc, v.29, p.299-301, Feb. 1942.

6. ANAISE, J.Z. Prevalence of dental caries among workers in the sweets industry in Israel. Community Dent Oral Epidemiol, v.6, n.6, p.286289, Nov. 1978.

7. ANDRADE, M. Doenças causadas por arsênico e seus compostos. In: FUNDAÇÃO JORGE DUPRAT FIGUEIREDO DE SEGURANÇA E MEDICINA DO TRABALHO. Curso de medicina do trabalho. São Paulo: Fundacentro, 1979a. v.4. p.1031-1033.

8. ANDRADE, M. Doenças causadas por mercúrio e seus compostos. In: FUNDAÇÃO JORGE DUPRAT FIGUEIREDO DE SEGURANÇA E MEDICINA DO TRABALHO. Curso de Medicina do Trabalho. São Paulo: Fundacentro, 1979b. v.4. p.1049-1051.

9. ARAUJO, M.E. Estudo da prevalência das manifestações bucais decorrentes de agentes químicos no processo de galvanoplastia: sua importância para a área de saúde bucal do trabalhador. São Paulo, 1998. 126p. Tese (Doutorado em Diagnóstico Bucal) - Faculdade de Odontologia da Universidade de São Paulo.

1* De acordo com NBR - 6023 da Associação Brasileira de Normas Técnicas, 1989. Abreviatura de periódicos segundo "Index to Dental Literature". 
10. ARAUJO, M.E.; GONINI Jr., A. Saúde bucal dos trabalhadores: os exames admissional e periódico como um Sistema de Informação em Saúde. Odontol Soc, v.1, n. 1/2, p.15-18, 1999.

11. ARAÚJO, N.S.; ARAÚJO, V.C. Patologia bucal. São Paulo: Artes Médicas, 1984. Cap. 3. 69-71p.

12. ARAÚJO, R.C.S.S.; SIQUEIRA, A.R.; UDIHARA, M.L.; MOTTA, R.M.M. Saúde bucal em portadores de lesões por esforços repetitivos (LER). Div Saúde Debate, v.10, p.54-56, jun. 1995.

13. ARBENZ, G.O. Introdução à odontologia legal. São Paulo: Linográfica, 1959. 248p.

14. ARBENZ, G.O. Medicina legal e antropologia forense. São Paulo: Atheneu, 1988a. Cap. 24. p.307-322.

15. ARBENZ, G.O. Medicina legal e antropologia forense. São Paulo: Atheneu, 1988b. Cap. 28. p.381-387.

16. AREIAS, R.L.F.C. A Fonoaudiologia e os distúrbios da comunicação humana. In: SEGER, L. Psicologia e odontologia: uma abordagem integradora. 3. ed. São Paulo: Santos, 1998. Cap. 22. p.383-403.

17. ASSOCIAÇÃO BRASILEIRA DOS SERVIÇOS ASSISTENCIAIS DE SAÚDE PRÓPRIOS DE EMPRESAS. Disponível em: http://www.abraspe.org.br Acesso em 19 ago. 2000.

18. ASSOCIAÇÃO PAULISTA DE ADMINISTRAÇÃO DE RECURSOS HUMANOS. Planos odontológicos. Empresas investem no benefício como diferencial. J Recursos Humanos, v.13, n. 770, 30/08/1998.

19. ASTON, E.R. Dental relations in a state industrial hygiene program. Ind Med, v.17, n.1, p.21-23, Jan. 1948.

20. ASTON, E.R. Dental review survey. Ind Med, v.15, n.8, p.483-484, Aug. 1946.

21. ASTON, E.R. Dental study of employees of five lead plants. Ind Med Surg, v.21, n.1, p.17-20, Jan. 1952.

22. ATHIAS, G. Mortes por câncer de boca crescem $50 \%$. Folha de São Paulo, São Paulo, 23 jul. 2000. Caderno Cotidiano, p. C9.

23. AUSTIN, L.T. Relationship of dental sepsis to systemic disease. J Am Dent Assoc, v.27, p.684-688, May. 1940.

24. AYER, W.A.; SEFFRIN, S.; WIRTHMAN, G.; DEATRICK, D.; DAVIS, D. Dental health promotion in the workplace. In: CATALDO, M.F.; 
COATES, T.J. Health and industry: a behavioral medicine perspective. Nova lorque: John Wiley, 1986. Cap. 10. p.255-269.

25. BALLANTINE, B.N.; COSTIGAN, F.; ANDERSON, R.J. A survey of the dental health of the workers on two groups of offshore installations. $\mathbf{J}$ Soc Occup Med, v.40, p.143-148, 1990.

26. BARNES, R.M. Estudos de movimentos e de tempos: projeto e medida do trabalho. São Paulo: Edgard Blücher, 1977. 635p.

27. BARON, R. Prophylaxis for phosphorus workers. Brit Dent J, v.76, p.331-332, June, 1944.

28. BARONI, G. A influência da dor de dente. Rev CIPA, v.17, n.202, p.40$51,1996$.

29. BATAWI, M.A.E. Health problems of industrial workers in Egypt. Ind Med Surg, v.41, n.2, p.18-23, Feb. 1972.

30. BAUM, H.B. Occupational diseases of the mouth. Dent Cosmos, v. 76, p.247-254, Feb. 1934.

31. BEDRIKOW, B. História natural das doenças profissionais devidas a agentes químicos. In: FUNDAÇÃO JORGE DUPRAT FIGUEIREDO DE SEGURANÇA E MEDICINA DO TRABALHO. Curso de medicina do trabalho. São Paulo: Fundacentro, 1979. v.1. p.6569.

32. BELLIBONI, N. Epidemiologia das dermatoses e dos cânceres profissionais. In: FUNDAÇÃO JORGE DUPRAT FIGUEIREDO DE SEGURANÇA E MEDICINA DO TRABALHO. Curso de medicina do trabalho. São Paulo: Fundacentro, 1979. v.1. p.71-90.

33. BERMAN, R. Dental activities in a medical center program. Ind Med Surg, v.21, n.3, p.115-116, Mar. 1952.

34. BIRMAN, E.G. Aspectos estomatológicos do saturnismo. Rev Assoc Paul Cir Dent, v.33, n.1, p.61-64, jan./fev. 1979.

35. BIRMAN, E.G.; ESTEVES, R.C.; SILVA, S.S.; MARCUCCI, G.; OLIVEIRA, Z.R.B.; ARAÚJO, N.S. Pigmentação labial por chumbo. Rev Assoc Paul Cir Dent, v. 36, n. 4, p.446-450, jul./ago. 1982.

36. BORAKS, S. Diagnóstico bucal. 2.ed. São Paulo: Artes Médicas, 1999. 417p.

37. BORRÁS, J.S.; SANFILIPPO, O.A. Problemas odonto-estomatológicos en el trabajo. In: CORTÉS, F.M. La salud en el trabajo. México: Novum Corporativo SA de CV, 1988. Cap.32. p.273-279. 
38. BOTAZZO, C.; BERTOLINI, S.R.; CORVÊLHO, V.M. Atenção em saúde bucal: condição atual do acesso a trabalhadores e adultos nos sistemas locais de saúde. Div Saúde Debate, n.10, p.43-53, jun. 1995.

39. BOUER, G. Qualidade: conceitos e abordagens. In: CONTADOR, J.C. coord. Gestão de operações: a engenharia de produção a serviço da modernização da empresa. São Paulo: Edgard Blücher, 1997. Cap. 14. p.177-187.

40. BRANDIMILLER, P.A. Perícia judicial em acidentes e doenças do trabalho. São Paulo: SENAC- SP, 1996. 306p.

41. BRASIL. Ministério da Saúde. Levantamento epidemiológico em saúde bucal: Brasil zona urbana, 1986. Brasília: Divisão Nacional de Saúde Bucal/FSESP, 1988. 137p.

42. BRASIL. Leis, decretos, etc. Lei 8080 , de 19 de setembro de 1990. Dispõe sobre as condições de para a promoção, proteção e recuperação da saúde, a organização e o funcionamento dos serviços correspondentes, e dá outras providências. Diário Oficial da União, Brasília, p.18055, set. 1990a.

43. BRASIL. Lei 8142 , de 28 de dezembro de 1990. Dispõe sobre a participação da comunidade na gestão do Sistema Único de Saúde - SUS e sobre as transferências intergovernamentais de recursos financeiros na área da saúde e dá outras providências. Diário Oficial da União, Brasília, p.25694, 29 dez. 1990b.

44. BRASIL. Lei no 8212 de 24 de julho de 1991. Dispõe sobre a organização da Seguridade Social, institui Plano de Custeio e dá outras providências. Diário Oficial da União, Brasília, 25 jul. 1991a.

45. BRASIL. Lei no 8213 de 24 de julho de 1991. Dispõe sobre os Planos de Benefícios da Previdência Social e dá outras providências. Diário Oficial da União, Brasília, 25 jul. 1991b.

46. BRASIL. Constituição. Constituição da República Federativa do Brasil, de 15 de outubro de 1988. São Paulo: Atlas, 1992. 200p.

47. BRASIL. Segurança e Medicina do Trabalho: lei n.6.514, de 22/12/77, normas regulamentadoras (nr) aprovadas pela portaria n.3.214, de $8 / 6 / 78$, normas regulamentadoras rurais (nrr) aprovadas pela portaria n.3.067, de 12/4/88 e índices remissivos. 39. ed. São Paulo: Atlas, 1998. 584p. (Manuais de Legislação Atlas, v.16)

48. BRASIL. Decreto $n^{\circ} 3048$ de 6 de maio de 1999. Aprova o regulamento da Previdência Social, e dá outras providências. Diário Oficial da União, Brasília, p.1, 12 maio 1999a. Seção 1. 
49. BRASIL. Portaria $\mathrm{n}^{\circ} 1339$ de 18 de novembro de 1999. Institui a Lista de Doenças relacionadas ao Trabalho. Diário Oficial da União, Brasília, p.21, 19 nov. 1999b.

50. BRASIL. Resolução INSS/DC/nํ 010, de 23 de dezembro de 1999 Aprova os Protocolos Médicos, com alterações realizadas pela Coordenação Geral de Benefícios por Incapacidade da Diretoria de Benefícios e dá outras providências. Rev CIPA, v.21, n.247, p.115306. 2000a.

51. BRASIL. Portaria no 10 de 6 de abril de 2000. Proposta de alteração da NR - 4 Serviço Especializado em Engenharia de Segurança e em Medicina do Trabalho - SESMT. Diário Oficial da União, Brasília, p.21, 7 abr. 2000b. Seção 1, p.19.

52. BRASIL. DATASUS. População total. Disponível em: htpp://www.datasus.gov.Br/cgi/tabcgi.exe?idb98/a01.def Acesso em: 19 ago. 2000b.

53. BRIÑON, E.N. Odontologia legal y practica forense. Buenos Aires: Purinzon, 1984. Cap. 5-6. p.135-195.

54. BROCK, D.W. Industrial dentistry and the general practitioner. Ind Med Surg, v.27, n.5, p.244-248, May 1958.

55. BRUGGENKATE, M.; CARDOZO, E.L.; MAASKANT, P.; WAAL, I. Lead poisoning with pigmentation of the oral mucosa. Oral Surg v.39, n.5, p.747-753, 1975.

56. BRYANT, G.W.T. Myofascial pain dysfunction and viola playing. Br Dent J, v.166, n.9, p.335-336, May 1989.

57. BUISCHI, Y.P. (Coord.) Promoção de saúde bucal na clínica odontológica. São Paulo: Artes Médicas, EAP-APCD, 2000. 336p.

58. BUONO NETO, A.; BUONO, E.A. Perícia e processo trabalhista. 2. ed. Curitiba: Gênesis, 1995. 275p.

59. BUREAU OF PUBLIC HEALTH DENTISTRY; BUREAU OF INDUSTRIAL HYGIENE. Dental programs in industry - suggested principles and policies. Ind Med, v.12, n. 11, p.780, Nov. 1943.

60. BURKET, L.W. Medicina bucal: diagnóstico y tratamiento. México: Interamericana, 1954. Cap. 7. p.71-89, Cap. 29. p.468-476.

61. CAETANO, J.C.; WATANABE, A.M. Noções básicas de Odontologia Ocupacional para profissionais da Saúde do Trabalhador. In: VIEIRA, S.I. Medicina básica do trabalho. 2. ed. Curitiba: Gênesis, 1994. v.3. p.169-190. 
62. CÂMARA, V.M.; SILVA, A.P.; PIVETTA, F.; PEREZ, M.A.; LIMA, M.I.M.; FILHOTE, M.I.F.; TAVARES, L.M.B.; MACIEL, M.V.; ALHEIRA, F.V.; DANTAS, T.; MARTINS, M.S. Estudo dos níveis de exposição e efeitos à saúde por mercúrio metálico em uma população urbana de Poconé, Mato Grosso, Brasil. Cad Saúde Publ, v.12, n.1, p.69-77, jan./mar. 1996.

63. CAMP, H.E. Dental service at Corning glass works. Ind Med Surg, v.24, n.11, p. 499, Nov. 1955.

64. CAMP, H.E. Industrial dentistry. Ind Med, v.16, n.8, p.401-403, Aug. 1947.

65. CAMPOS, J.L.D. O Ministério Público e o Meio Ambiente do Trabalho - Responsabilidade Civil e Criminal do Empregador e Prepostos. São Paulo: FUNDACENTRO, 1991.11p.

66. CARRANZA Jr., F.A. Influencia de doenças sistêmicas no periodonto. In: CARRANZA Jr., F.A.; NEWMAN, M.G. Periodontia clínica. 8. ed. Rio de Janeiro: Guanabara Koogan, 1997. Cap.14. p.192-214.

67. CARRYER, H.M.; RANDALL, R.V.; MANKIN, H.T.; CARTER, E.T. Analysis of 2812 examinations on 569 subjects at Mayo Clinic. Ind Med Surg, v.41, n.5, p.13-16, May 1972.

68. CARVALHO, A.V.; NASCIMENTO, L.P. Administração de recursos humanos. 2. ed. São Paulo: Pioneira, 1997. v.1. 339p.

69. CARVALHO, G.I.; SANTOS, L. Sistema Único de Saúde: comentários à Lei Orgânica da Saúde (Lei 8.080/90 e Lei 8.142/90). São Paulo: Hucitec, 1995. 394p.

70. CARVALHO, H.V.; BRUNO, A.M.L.; SEGRE, M. Lições de medicina legal. 3. ed. São Paulo: Saraiva, 1965, Cap. 8. p.227-234.

71. CARVALHO, J.G. Odontologia sanitária e implicações ocupacionais. Rev Fac Odontol Univ Fed Bahia, v.1, p.75-86, jan./dez. 1981.

72. CATE, H.J.T.B. Dental erosion in industry. Brit J Ind Med, v.25, p.249266, 1968.

73. CERVO, A.L.; BERVIAN, P.A. Metodologia científica. 4.ed. São Paulo: Makron, 1996. 209p.

74. CHAVES, M.M. Odontologia social. 3.ed. São Paulo: Artes Médicas, 1986. 448p.

75. CHIAVENATO, I. Recursos humanos. 3.ed. São Paulo: Atlas, 1995. $525 p$. 
76. CIPOLLA-NETO, J.; MARQUES, N.; MENNA-BARRETO, L.S. Introdução ao estudo da cronobiologia. São Paulo: Ícone, 1988. $270 \mathrm{p}$.

77. COMITÊ DE INTEGRAÇÃO DE ENTIDADES FECHADAS DE ASSISTÊNCIA À SAÚDE. Disponível em: http://www.ciefas.com.br Acesso em 19 ago. 2000.

78. CONSELHO FEDERAL DE ODONTOLOGIA. Números do CFO em todos os Estados. Disponível em: http://www.cfo.org.br/cgi/cfml.exe?template=/novonumero.cfm\&cro=todos Acesso em 17 ago 2000.

79. CONSELHO REGIONAL DE ODONTOLOGIA DE SÃO PAULO O dente pode matar. J CROSP, v.22, n.92, p.8-9, jun. 2000.

80. CONTADOR, J.C. Produtividade. In: CONTADOR, J.C. (Coord.). Gestão de operações: a engenharia de produção a serviço da modernização da empresa. São Paulo: Edgard Blücher, 1997. Cap.9. p.119-136.

81. COUNCIL ON DENTAL HEALTH. Industrial dental programs. J Dent Am Assoc, v. 45, n. 7, p.46-47, July 1952.

82. COWELL, C.R. The national health service and dentistry in industry. Ind Med Surg, v.35, n.4, p.278-285, Apr. 1966.

83. DECCA, E.S. O nascimento das fábricas. São Paulo: Brasiliense, 1996. 79 p.

84. DECHAUME, M. \& GARLOPEAU, F. Les manifestations bucales au cours des maladies professionneles. In: DESOILLE, H. Cours de médecine du travail. 2.ed. Paris: Librairie E. Le François, 1957. tomo 2. p. 269-283.

85. DECHAUME, M. Lésions buccales, dentaires et maxillaires dans les maladies professionnelles. In: DESOILLE, $\mathrm{H}$. Cours de médecine du travail. Paris: Librairie E. Le François, 1949. p.523-536.

86. DEJOURS, C. Construire as santé. In: CASSOU, B. et al. Les risques du travail: pour ne pas perdre sa vie à la gagner. Paris: La Découverte, 1985. p.18-21.

87. DEMING, W.E. Qualidade: a revolução da administração. Rio de Janeiro: Marques-Saraiva, 1990. 367p.

88. DESOILLE, H.; SCHERRER, J.; TRUHAUT, R. Affections buccales, dentaires et maxillaries. In: Précis de médecine du travail. Paris: Masson, 1975. p.573-577. 
89. DIACOV, N.; LIMA, J.R.S. Absenteísmo odontológico. Rev Odontol UNESP, v.17, n.1/2, p.183-189, 1988.

90. DIAS, E.C. Organização da atenção à saúde dos trabalhadores. In: FERREIRA Jr., M. Saúde no trabalho: temas básicos para o profissional que cuida da saúde dos trabalhadores. São Paulo: Roca, 2000. Cap.1. p.3-28.

91. DINI, E.L.; CASTELLANOS, R.A. CPITN: time and cost estimates for periodontal prevention and treatment procedures. Braz Dent J, v.6, n.1, p.53-58, 1995.

92. DÓRIA, A. M. Infortunística e odontologia. Rio de Janeiro: Of. Gr. de A Noite, 1941. 159p.

93. DOUGHERTY, H.H. Industrial dental health program sponsored by the cooperative service, Wyomissing, Pennsylvania. Ind Med Surg, v.20, n.9, p.408-410, Sept. 1951.

94. DOUGHERTY, H.H. The role of the Dental Society in occupational health. Ind Med Surg, v. 28, n.7, p.325-326, July 1959.

95. DUFFY, B. Dental problems in the offshore oil and gas industry: a review. Occup Med, v.46, n.1, p.79-83, 1996.

96. DUNNING, J.M. Dental aspects of industrial absenteeism. Ind Med Surg, v.21, n.9, p.431-432, Sept. 1952.

97. DUNNING, J.M. Steps in the initiation of an industrial dental service. $\mathbf{J}$ Am Dent Assoc, v. 29, n.11, p.1523-1527, Aug. 1942.

98. DUNNING, J.M. Your teeth and your job. Ind Med, v.14, n.4, p.318-320, Apr. 1945.

99. DUNNING, J.M.; KLEIN, H. Saving teeth among home office employes of the Metropolitan Life Insurance Company. J Am Dent Assoc, v.31, n.12, p.1632-1642, Dec. 1944.

100.DUNNING, J.M.; WALLS, R.M.; LEWIS, S.R. Prevalence and characteristics of dental service in industry. J Am Dent Assoc, v. 28, p.492-501, Mar. 1941.

101. DURAFFOURG, J. La relation santé-travail: une question complexe. In: CASSOU, B.; HUEZ, D.; MOUBEL, M.C.; SPTIZER, C.; TOURANCHET, A. Les risques du travail: pour ne pas perdre sa vie à la gagner. Paris: La Découverte, 1985. p. 21-27.

102. EGBERT, B.; TOLEDO, C.; ROSSA Jr., C. Influências das condições sistêmicas sobre as doenças periodontais e das doenças periodontais sobre as condições sistêmicas. In: TUNES, U.R. 
Atualização em periodontia e implantodontia. São Paulo: Artes Médicas, 1999. Cap. 3. p.29-60.

103. EKSTRAND, K. Diagnóstico da cárie. In: BUISCHI, Y.P. Promoção de saúde bucal na clínica odontológica. São Paulo: Artes Médicas/ EAP-APCD, 2000. Cap.6. p.125-148.

104. ENBOM, L.; MAGNUSSON, T.; WALL, G. Occlusal wear in miners. Swed Dent J, v.10, n.5, p.165-170, 1986.

105. ESCÓSSIA, F.; CLEMENTE, I. Cai o número de empregados com registro. Folha de São Paulo. São Paulo, 21 jul. 2000. Folha Dinheiro. p. B1.

106. ESTEVES, R.C. Manifestações bucais de doenças profissionais. Rev Bras Saúde Ocup, v.10, n.40, p.56-58, out./dez. 1982.

107. ESTEVES, R.C.; SBRISSA NETTO, J.M.; MOUCDCY, A. Algumas considerações sobre as manifestações bucais do saturnismo. Fac Odontol São Paulo, v.18, n.1, p.25-34, jan./jun. 1980.

108. FAHMY, M.S. Oral and dental affections in mercury-exposed workers. Community Dent Oral Epidemiol, v.6, n.4, p.161-165, july 1978.

109. FÁVERO, F. Medicina legal. 5.ed. São Paulo: Martins, 1954. v.2. p.552.

110. FEAVER, G.P. Occupational dentistry: a review of 100 years of dental care in the workplace. J Occup Med, v.38, n.1/2, p.41-43, 1988.

111. FELTON, J.S. The heritage of Bernardino Ramazzini. Occup Med, v.47, n.3, p.167-179, 1997.

112. FERNANDES, E. Qualidade de vida no trabalho: como medir para melhorar. 2.ed. Salvador: Casa da Qualidade, 1996. 121p.

113. FERRARI, C.H.; MEDEIROS, J.M.F.; SIMI Jr., J. Ocorrência de traumatismo dental e nível de esclarecimento e uso do protetor bucal em diferentes grupos de esportistas. Disponível em: http://odontologia.com.br/artigos/traumatismo-dental.html Acesso em: 09 mar. 2000b. 6p.

114. FERRARI, C.H.; MEDEIROS, J.M.F.; SIMI Jr., J.; CARRASCOZA, A. Epidemiologia e etiologia do traumatismo dental em dentes permanentes na região de Bragança Paulista. Disponível em: http://odontologia.com.Br/artigos/epidemiologia-etiologia.html Acesso em: 27 fev. 2000a. 16p. 
115. FERRAZ, C.; BELLINI, H.T. Condições dentárias de um grupo de trabalhadores adultos em Jundiaí (SP). Rev Assoc Paul Cir Dent, v. 37, n. 4, p.330-335, jul./ago. 1983.

116. FERREIRA, B. Atendimento odontológico cresce $453 \%$. Direito ou privilégio? Rev Assoc Bras Odontol, v.2, n.5, p.317-324, out./nov. 1994.

117. FERREIRA, R.A. O valor da saúde bucal nas empresas. Rev Assoc Paul Cir Dent, v. 49, n.2, p.96-107, mar./abr. 1995.

118. FERREIRA, R.A. Odontologia: essencial para a qualidade de vida. Rev Assoc Paul Cir Dent, v. 51, n.6, p.514-521, nov./dez. 1997.

119. FIALHO, F.; SANTOS, N. Manual de análise ergonômica do trabalho. 2. ed. Curitiba: Gênesis, 1997. 316 p.

120. FISHER, F.M.; PARAGUAY, A.I.B.B. A Ergonomia como instrumento de pesquisa e melhoria das condições de vida e trabalho. In: FISHER, F.M.; GOMES, J.R.; COLACIOPPO, S. Tópicos de saúde do trabalhador. São Paulo: Hucitec, 1989, 239p.

121. FRANÇA, G. Medicina legal. 4.ed. São Paulo: Guanabara-Koogan, 1995. Cap.6. p. $122-125$

122. FURUHATA, T.; YAMAMOTO, K. Presumption of occupation by the teeth. In: FURUHATA, T.; YAMAMOTO, K. Forensic odontology. Illinois: Charles C. Thomas, 1967. Cap. 6. p.89-95.

123. GARRAFA, V. Odontologia do trabalho. Rev Saúde Debate n.18, p.510, mar./abr. 1986a.

124. GARRAFA, V. Odontologia do trabalho. RGO v.34, n.6, p.508-512, nov./dez., 1986b.

125. GIBSON, A.; CARLISLE, J.M.; HOCH, S.M. Dental program in industry. Ind Med, v. 19, n. 1, p. 37-38, Jan., 1950.

126. GIL, A.C. Métodos e técnicas de pesquisa social. 5. ed. São Paulo: Atlas, 1999. 206p.

127. GOBBATO, F. Mouth and Teeth. In: ORGANIZAÇÃO INTERNACIONAL DO TRABALHO. Encyclopaedia of occupational health and safety. 4.ed. Geneva: International Labour Office, 1998. v.1. p. 4.34.5 .

128. GOLDHORN, E. Dental infections and the industrial worker. J Am Dent Assoc, v.29, n.1, p.118-126, Jan. 1942. 
129. GOLDHORN, E. Industrial toothache - an industrial dentist explains the importance of dental care in an industrial health program. Ind Med, v.16, n.3, p.140-145, Mar. 1947.

130. GOLDHORN, E. The role of dentistry in a industrial medical program. Ind Med, v.12, n.5, p.322, May 1943.

131. GOMES, E.B.; MAGALHÃES, H. Censo Bucal na empresa - sua importância no planejamento da assistência odontológica. Odontol Mod, v.7, n.3, p. 31-38, mar. 1980.

132. GOMES, J.R. Doenças causadas por chumbo e seus compostos. In: FUNDAÇÃO JORGE DUPRAT FIGUEIREDO DE SEGURANÇA E MEDICINA DO TRABALHO. Curso de medicina do trabalho. São Paulo: Fundacentro, 1979. v.4. p.1041-1047.

133. GONÇALVES, E.L. A empresa e a saúde do trabalhador. São Paulo: Pioneira, Edusp, 1988. 135p.

134. GONÇALVES, E.L. O Serviço médico da empresa. São Paulo: Edusp, 1994. 367p.

135. GONÇALVES, M.H.B.; WISE, N. Ética e trabalho. Rio de Janeiro: Senac Nacional, 1997. 96p.

136. GORDON, N.C.; BROWN, S.; KHOSLA, V.M.; HANSEN, L.S. Lead poisoning: a comprehensive review and report of a case. Oral Surg Oral Med Oral Pathol, v. 47, n. 6, p. 500-512, June 1979.

137. GRAZIANI, M. Cirurgia buco-maxilo-facial. 7.ed. Rio de Janeiro: Guanabara-Koogan, 1983. Cap. 29. p.595-596.

138. GRAZIANI, M. Traumatologia maxilo-facial. 1.ed. Rio de Janeiro: Guanabara-Koogan, 1982. Cap.9. p.184-187.

139. GREEN, C. Os caminhos da qualidade. São Paulo: Makron Books, 1995. 203p.

140. GREEN, L.W.; TRYON, W.W.; MARKS, B.; HURYN, J. Periodontal disease as a function of life events stress. J Hum Stress, v.12, n.1, p.32-36, Spring 1986.

141. GREENWOOD, A.H. The dental program in a retail establishment. Ind Med Surg, v.27, n.9, p.477-479, Sept. 1958.

142. GREGORI, C. Cirurgia odontológica para o clínico geral. São Paulo: Sarvier, 1987. 217p. 
143. GUIDUGLI NETO, J. Infecção focal e focos de infecção. In: TOMMASI, A.F. Diagnóstico em patología bucal. São Paulo: Artes Médicas, 1988. Cap. 11. p.182-188.

144. GUIMARÃES, E.; ROCHA, A.A. Odontologia do trabalho - $1^{\text {a }}$ parte. Organização dos serviços odontológicos de uma empresa. Odontol Mod, v.7, n.7, p.7-12, jul. 1979a.

145. GUIMARÃES, E.; ROCHA, A.A. Odontologia do Trabalho - $2^{\underline{a}}$ parte. Organização dos serviços odontológicos de uma empresa. Odontol Mod, v.7, n.8, p.23-26, ago. 1979b.

146. GUIMARÃES, E.; ROCHA, A.A. Odontologia do Trabalho - 3 a parte. Organização dos serviços odontológicos de uma empresa. Odont Mod, v.7, n.9, p.40-50, set. 1979c.

147. GUPTA, B.N. Occupational diseases of teeth. J Soc Occup Med, v.40, n.4, p.149-152, 1990.

148. HAHN, M.J. The dental status of workers on offshore installations in the UK oil and gas industry. Br Dent J, v.163, p.262-264, 1987.

149. HASSELL, T.M. Ações locais e sistêmicas de medicamentos e outros agentes químicos sobre os tecidos periodontais. In: GENCO, R.J.; COHEN, D.W.; GOLDMAN, H.M. Periodontia contemporânea. 3.ed. São Paulo: Santos. 1999. Cap. 21. p.269-276.

150. HEACOCK, L. D. Dental services. In: GAFAFER, W.M. Manual of industrial hygiene and medical service in war industries. U.S.A.: W.B. Saunders, 1943. Cap.6. p.88-97.

151. HEACOCK, L. D. Prevention of oral disease of occupational origin. Ind Med, v.15, n.3, p.184-187, Mar. 1946.

152. HEACOCK, L. D. The place of Dentistry in industrial health programs. Ind Med, v.12, n.10, p.672-680, Oct. 1943.

153. HEACOCK, L.D. Dental relations in industrial health services. Ind Med, v.16, n.1, p.5-9, Jan. 1947.

154. HELÖE, B.; HELÖE, L.A.; HEIBERG, A. Relationship between sociomedical factors and TMJ-symptoms in Norwegians with Myofascial Pain-Dysfunction Syndrome. Community Dent Oral Epidemiol, v. 5, n. 5, p.207-212, 1977.

155. HIRSCH, J.A.; McCALL Jr., W.D.; BISHOP, B. Jaw dysfunction in viola and violin players. J Am Dent Assoc, v.104, n.6, p.838-843, June 1982. 
156. HOLLISTER, M.C.; WEINTRAUB, J.A. The association of oral status with systemic health, quality of life, and economic productivity. $\mathbf{J}$ Dent Educ, v.57, n.12, p.901-912, Dec. 1993.

157. HOOPER, H.A. Dental ill-health - in relation to absenteeism. Ind Med, v.12, n. 1, p. 3-4, Jan. 1943.

158. HOOPER, H.A. Dental Services in industry - Observations on their effects in the redution of absenteeism. Ind Med, v.11, n. 4, p. 157162, Apr. 1942.

159. HUBERMAN, L. História da riqueza do homem. 20.ed. Rio de Janeiro: Zahar, 1984. 318p.

160. HUGHES, J.P.W.; BARON, R.; BUCKLAND, D.H.; COOKE, M.A.; CRAIG, J.D.; DUFFIELD, D.P.; GROSART, A.W.; PARLES, P.W.J.; PORTER, A.; FRAZER, A.C.; HALLAM, J.W.; SNAWDON, J.W.E.; TAVENNER, R.W.H. Phosphorus necrosis of the jaw: a presentday study with clinical and biochemical studies. $\mathrm{Br} \mathbf{J}$ Industr Med, v.19, p.83-99, 1962.

161. IIDA, I. Ergonomia: projeto e produção. São Paulo: Edgard Blücher, 1993. 465p.

162. INSTITUTO BRASILEIRO DE GEOGRAFIA E ESTATÍSTICA. Dados históricos dos censos. Disponível em: http://www.ibge.gov.br/estatística/população/censohistorico/1940 19 96.shtm Acesso em 17 ago. 2000.

163. JENNY, J.; PROSHEK, J.M. Visibility and prestige of occupations and the importance of dental appearance. J Can Dent Assoc, v.52, n.12, p.987-989, Dec. 1986.

164.KATZ, R.V.; BARNES, G.P.; LARSON, H.R.; LYON, T.C.; BRUNNER, D.G. Epidemiologic survey of accidental dentofacial injuries among U.S. Army personnel. Community Dent Oral Epidemiol, v. 7, n. 1, p.30-36, 1979.

165. KAWAMURA, M.; WRIGHT, F.A.C.; SASAHARA, H.; YAMASAKI, Y.; SUH, S.; IWAMOTO, Y. An analytical study on gender differences in self-reported oral health care and problems of Japanese employees. J Occup Health, v.41, p.104-111, Apr. 1999.

166. KITAMURA, S. Doenças causadas por gases e vapores tóxicos. In: FUNDAÇÃO JORGE DUPRAT FIGUEIREDO DE SEGURANÇA E MEDICINA DO TRABALHO. Curso de medicina do trabalho. São Paulo: Fundacentro, 1979a. v.4. p.1027-1029.

167. KITAMURA, S. Doenças causadas por fósforo e seus compostos. In: FUNDAÇÃO JORGE DUPRAT FIGUEIREDO DE SEGURANÇA E 
MEDICINA DO TRABALHO. Curso de medicina do trabalho. São Paulo: Fundacentro, 1979b. v.4. p.1035-1039.

168. KITAMURA, S.; FERREIRA Jr., Y.M. Câncer ocupacional: introdução ao tema e propostas para uma política de prevenção e controle. São Paulo: Fundação Oncocentro de São Paulo, 1991. 48p.

169. KNUDTZON, K.F. Aviation Dentistry (Aerodontia). In: MILLER, S.C. Oral diagnosis and treatment (oral medicine): a textbook for students and practitioners of dentistry and medicine. 3.ed. New York: McGrow Hill, 1957. Cap.28. p.815-840.

170. KRIGER, L. (Coord.). Promoção de saúde bucal. São Paulo: Artes Médicas, 1997. 475p.

171. KULSTAD, H.M. The place of Dentistry in industry. Ind Med, v.14, n.3, p.234-235, Mar.1945.

172. L`ÉPÉE, P.; LAZARINI, H.J.; TOUSSAINT, J.; DOIGNON, J. Arch Mal Prof, v.30, n.7-8, p.428-431, juil./août. 1969.

173. LAKATOS, E.M.; MARCONI, M.A. Metodologia científica. 2.ed. São Paulo: Atlas, 1991. 249p.

174. LASCALA, N.T.; MOUSSALLI, N.H. Compêndio terapêutico periodontal. 2.ed. São Paulo: Artes Médicas. 1995. 522p.

175. LEAVELL, H.R.; CLARK, E.G. Medicina preventiva. São Paulo: McGraw-Hill do Brasil, 1976. 744p.

176. LEGGE, R.T. The history of industrial medicine and occupational diseases. Ind Med, v.5, n.6, p.300-314, Jan. 1936.

177.LEGGE, R.T. The history of industrial medicine and occupational diseases. Ind Med, v.6, n. 1, p.34-37, Jan. 1937.

178. LEONARDO, M.R.; LEAL, J.M. Endodontia: tratamento de canais radiculares. 2.ed. São Paulo: Panamericana, 1991. 594p.

179. LIM, L.P.; DAVIES, W.I.R. Comparison of various modalities of "simple" periodontal therapy on oral cleanliness and bleeding. $\mathbf{J}$ Clin Periodontol, v.23, n.6, p.595-600, June 1996.

180. LIMA, J.R.S. Absenteísmo por causa odontológica. Análise comparativa entre funcionários da prefeitura do município de São José dos Campos e segurados do Instituto Nacional de Previdência Social INAMPS. Disponível em: http://www.odontologia.com.br/artigos/absenteismo.html Acesso em 03 maio 1997. 
181. LIVRAGHI, D.E. Auditoria odontológica. Rev San Mil Arg, p.152-157, 1983.

182. MacKENZIE, G. Dentistry at the Ford Motor Company. Ind Med Surg, v. 20, n.7, p.331-332, July 1951.

183. MARANO, V.P. Medicina do Trabalho: exames médicos admissionais, periódicos: provas funcionais. São Paulo: LTr, 1987. 192p.

184. MARANO, V.P. Organização de serviços de medicina do trabalho nas empresas. São Paulo: LTr, 1989. 149p.

185. MARCONI, M.A.; LAKATOS, E.M. Técnicas de pesquisa: planejamento e execução de pesquisas, amostragens e técnicas de pesquisas, elaboração, análise e interpretação de dados. 4.ed. São Paulo: Atlas, 1999. 260p.

186. MARQUES, N.; MENNA-BARRETO, L. Cronobiologia: princípios e aplicações. São Paulo:EDUSP, 1997. 321p.

187. MARTORELLI, S.B.F.; BRAGA, P.M.; BARBOSA, D.M.; RIBEIRO, M.; BARBOSA, M. Traumatismo facial por acidente de trabalho: relato de um caso clínico. Disponível em: http://www.odontologia.com.br/artigos/traumatismo-facial.html Acesso em 29 maio 2000.

188. MASALIN, K.; MURTOMAA, H.; MEURMAN, J.H. Oral health of workers in the modern Finnish confectionery industry. Community Dent Oral Epidemiol, v.18, n.3, p.126-130, June 1990.

189. MASCIA, F.L., SZNELWAR, L.I. Ergonomia. In: CONTADOR, J.C. coord. Gestão de operações: a engenharia de produção a serviço da modernização da empresa. São Paulo: Edgard Blücher, 1997. Cap. 13. p.165-176.

190. MATOS, A.;LEÃO, J.A. O exame médico admissional: sua importância na prevenção de acidentes nos trabalhos de ar comprimido. In: CONGRESSO NACIONAL DE PREVENÇÃO DE ACIDENTES DO TRABALHO, 1975, Rio de Janeiro, Anais... São Paulo: Fundacentro, 1975. p.911-916.

191. McCORD, C.P. Occupational disease manifestations inn dental impairments. Ind Med, v.19, n.8, p.387-388, Aug. 1950.

192. MEDEIROS, E.P.G. Exame odontológico pré-admissional. O Incisivo, v.4, n.1, p.18-22, jan. 1965.

193. MEDEIROS, E.P.G. Conceito de odontologia do trabalho. O Incisivo, v.5, n.24, p.22-24, nov. 1966. 
194. MEDEIROS, E.P.G.; BIJELLA, V.T. Bases para a organização de programas dentais para operários. Rev Bras Odontol, v.27, n.166, p.303-311, nov./dez. 1970.

195. MEDEIROS, E.P.G.; BIJELLA, V.T. Aplicação racional da odontologia social no atendimento de operários. Rev Bras Odontol, v.28, n.172, p.276-280, nov./dez. 1971.

196. MENDES, R. Medicina do trabalho e doenças profissionais. São Paulo: Sarvier, 1980. 573p.

197. MENDES, R. ; DIAS, E. C. Da medicina do trabalho à saúde do trabalhador. Rev Saúde Pública, v.25, n.5, p.341-9, 1991.

198. MENDES, R. Patologia do trabalho. Rio de Janeiro: Atheneu, 1995, $643 p$.

199. MIDORIKAWA, E.T.; NAGANO, I.N. The Importance of the Odontology in Occupational Health. In: SIMPÓSIO NIPO-BRASILEIRO DE CIÊNCIA E TECNOLOGIA, 1995, Campos do Jordão. Anais... Campos do Jordão: ACIESP, 1995. p.183-185.

200. MIDORIKAWA, E.T.; NAGANO,I.N.; CARDOZO, H.F. The role of the dentist in relation of the oral manifestation of the occupational disease. In: CONGRESSO INTERNACIONAL FORENSE'96. CONGRESSO BRASILEIRO DE ODONTOLOGIA LEGAL, 1996, São Paulo. Anais... São Paulo: FMUSP, 1996. p.43.

201. MILLER, E.W. Dental program in industry. Ind Med, v.10, n.3, p.104106, Mar. 1941.

202. MISHER, K.W. Practical application of an industrial dental program. Ind Med, v.15, n.2, p.113-114, Feb. 1946.

203. MOLINIÉ, A.F.; VOLKOF, S. Accidents du travail: des maux et des chiffres. In: CASSOU, B.; HUEZ, D.; MOUBEL, M.C.; SPTIZER, C.; TOURANCHET, A. Les risques du travail: pour ne pas perdre sa vie à la gagner. Paris: La Découverte, 1985. p. 31-36.

204. MORREY, L.W. You are only as healthy as your teeth. Ind Med, v.13, n.10, p.777, Oct. 1944.

205. MORSE, D. R. Stress and bruxism: a critical review and report of cases. J Hum Stress, v.8, n.1, p.43-54, Mar. 1982.

206. MORVAY, L.S. Conservative procedures in the treatment of acute dental injuries in industry. Ind Med, v.17, n.3, p.87-88, Mar. 1948.

207. MORVAY, L.S. Compensation laws in relation to dental and jaw injuries. Ind Med Surg, v.21, n.10, p.473-476, Oct. 1952. 
208. MORVAY, L.S. The physician and dental and jaw injuries. Ind Med Surg, v.24, n.7, p.307-308, July 1955.

209. MORVAY, L.S. The dentist's role in dental compensation claims. Ind Med Surg, v.26, n.9, p.430-432, Sept. 1957.

210. MORVAY, L.S.;KABAN, N.J.L.B.; DUNNING, J.M. State compensation laws for dental and jaw injuries. J Occup Med, v.9, n.8, p.388-396, Aug. 1967.

211. MOTTA, R.G.; ALBUQUERQUE, V.L.T. Organização e implantação do serviço odontológico em uma industria mecânica S.A.. Quintessence, v.10, n.10, p.25-33, out. 1983.

212. MOTTA, R.G.; TOLEDO, V.L. Avaliação de resultados de plano odontológico em industria mecânica. Rev Bras Saúde Ocup, v.12, n.46, p.64-71, abr.jun. 1984.

213. MOYSÉS, S.J. O conceito de promoção de saúde na construção de sistemas de atenção em saúde bucal coletiva. In: KRIGER, L. (Coord.). Promoção de saúde bucal. São Paulo: Artes Médicas, 1997. Cap. 16. p.371-407.

214. NASCIMENTO FILHA, O.B. Febre dos fumos metálicos. In: FUNDAÇÃO JORGE DUPRAT FIGUEIREDO DE SEGURANÇA E MEDICINA DO TRABALHO. Curso de medicina do trabalho. São Paulo: Fundacentro, 1979. v.4. p.1071-1073.

215. NEFUSSI, N. Conceituação de saúde ocupacional. In: FUNDAÇÃO JORGE DUPRAT FIGUEIREDO DE SEGURANÇA E MEDICINA DO TRABALHO. Curso de medicina do trabalho. São Paulo: Fundacentro, 1979. v.1, p.13-17.

216. NOGUEIRA, D. P. Odontologia e saúde ocupacional. Rev Saúde Públ, v.6, p.211-223, 1972.

217. NOGUEIRA, D. P. Introdução à segurança, higiene e medicina do trabalho - Histórico. In: FUNDAÇÃO JORGE DUPRAT FIGUEIREDO DE SEGURANÇA E MEDICINA DO TRABALHO. Curso de medicina do trabalho. São Paulo: Fundacentro, 1979. v.1, p. 5-10.

218. NYSETHER, S. Dental injuries among Norwegian soccer players. Community Dent Oral Epidemiol, v.15, n.3, p.141-143, June 1987.

219. OKESON, J.P. Fundamentos de oclusão e desordens temporomandibulares. 2.ed. São Paulo: Artes Médicas, 1992. 449p.

220. ORGANIZAÇÃO INTERNACIONAL DO TRABALHO. R112 Recomendação sobre os serviços de medicina do trabalho 
(adotada em 24/06/1959). Disponível em: http:// ilolex.ilo.ch:1567/scripts/convds.pl?query=R112\&query1=R112\&sub mit=Visualizar Acesso em 22 ago. 2000a.

221. ORGANIZAÇÃO INTERNACIONAL DO TRABALHO. C161 - Convênio sobre os serviços de saúde no trabalho (adotada em 25/06/1985). Disponível em: http:// ilolex.ilo.ch:1567/scripts/convds.pl?query=C161\&query $0=C 161 \&$ sub mit=Visualizar Acesso em 22 ago. 2000b.

222. ORGANIZAÇÃO INTERNACIONAL DO TRABALHO. R171 Recomendação sobre os serviços de saúde no trabalho (adotada em 26/06/1985). Disponível em: http:// ilolex.ilo.ch:1567/scripts/convds.pl?query=R171\&query1=R171\&sub mit=Visualizar Acesso em 22 ago. 2000c.

223. ORGANIZAÇÃO MUNDIAL DE SAÚDE. Levantamentos Básicos em Saúde Bucal. 4.ed. São Paulo: Santos. 1999. 66p.

224. OTOMO-CORGEL, J. Tratamento periodontal de pacientes com doenças sistêmicas. In: CARRANZA Jr, F.A.; NEWMAN, M.G. Periodontia clínica. 8.ed. Rio de Janeiro: Guanabara Koogan, 1997. Cap. 34. p.432-448.

225. PAIVA, J.G.; ANTONIAZZI, J.H. Endodontia: bases para a prática clínica. São Paulo: Artes Médicas, 1984, p.18.

226. PAIXÃO, F. A previdência social. 29.ed. Porto Alegre: Síntese, 1994. $636 \mathrm{p}$.

227. PASSOS, A.S.; VILLELA, F. Odontologia na saúde ocupacional. Vida Odontol, v.6, n.15, p.75-80, dez. 1983.

228. PERES, A.S. Perícia de convênio odontológico. São Paulo, 1997. 100p. Dissertação (Mestrado em Deontologia e Odontologia Legal)

- Faculdade de Odontologia da Universidade de São Paulo.

229. PERES, M.A.A. Saúde bucal dos trabalhadores. São Paulo: DS Butantã, 1989. 19p.

230. PETERSEN, P.E. Dental health among workers at a Danish chocolate factory. Community Dent Oral Epidemiol, v.11, n.6, p.337-341, Dec. 1983.

231. PETERSEN, P.E. Procesevaluering af et forebyggende tandplejeprogram for chokoladearbejdere. Tandlaegebladet, v.92, n.14, p.572-576, 1988. 
232. PETERSEN, P.E. Evaluation of a dental preventive program for Danish chocolate workers. Community Dent Oral Epidemiol, v.17, n.2, p.53-59, 1989.

233. PETERSEN, P.E.; GORMSEN, C. Oral conditions among German battery factory workers. Community Dent Oral Epidemiol, v.19, n.2, p.104-106, 1991.

234. PETTIBONE, E.L. Industrial Dentistry. J Am Dent Assoc, v.10 p.10301031, 1923.

235. PETTY, F.F. What is necessary to make industrial dentistry a credit to the dental profession? J Am Dent Assoc, v.30, p.1418-1427, Sept. 1943.

236. PIMENTEL, F.; RUSSO, M.; NEIVA, A. Aspectos sociais do tratamento protético em grupos operários. Rev Farm Odontol, v.28, n.250, p.22-25, dez. 1961.

237. PIMENTEL, O.J.A. Odontologia do Trabalho. Odontol Mod v.3, n.2, p.98-99, mar./abr. 1976.

238. PINTO, V.G. Saúde bucal: odontologia social e preventiva. 3.ed. São Paulo: Santos, 1992. 415p.

239. PINTO, V.G. A odontologia brasileira às vésperas do ano 2000: diagnóstico e caminhos a seguir. São Paulo: Santos, 1993. 189p.

240. PINTO, V.G. A odontologia no município: guia para organização de serviços e treinamento de profissionais a nível local. Porto Alegre: RGO, 1996. 252p.

241. PINTO, V.G. Saúde bucal coletiva. 4.ed. São Paulo: Santos, 2000. $541 p$.

242. PIZZARO, G. Relações específicas entre trabalho e órgãos do sentido. In: FUNDAÇÃO JORGE DUPRAT FIGUEIREDO DE SEGURANÇA E MEDICINA DO TRABALHO. Curso de medicina do trabalho. São Paulo: Fundacentro, 1979. v.5. p.1183-1185.

243. PRICE, W.A Dental infections and related degenerative diseases: some structural and biochemical factors. J Am Med Assoc, v.84, n.4, p.254-259, 1925.

244. PUEYO, V.M.; GARRIDO, B.R.; SÁNCHEZ, J.A.S. Odontología legal y forense. Barcelona: Masson, 1994. Cap.18. p.195-201.

245. PUFFER, R.R. ; SEBELIUS, C.L. Absenteeism in Tennessee industrial plants caused by diseases of the teeth and gums. J Am Dent Assoc, v.33, n.9, p.1122-1131, Sept. 1946. 
246. RAHDE, A.F.; SALVI, R.M. Semiologia toxicológica do aparelho digestivo - efeitos locais. Rev Med PUCRS, v.1, n.3, p.114-117, abr./jun. 1989.

247. RAHDE, A.F.; SALVI, R.M. Toxicologia da boca. Porto Alegre: SagraDC Luzzatto, 1992. 100p.

248. RAJALA, A.L.; RAJALA, M.; PAUNIO, I. Utilization of dental care in a Finnish industrial population. Community Dent Oral Epidemiol, v.6, n.3, p.121-125, 1978.

249. RAMAZZINI, B. As doenças dos trabalhadores. Trad. Raimundo Estrela. São Paulo: Fundacentro, 1992. 180p.

250. REISINE, S.T. Dental disease and work loss. J Dent Res, v.63, n.9, p.1158-1161, Sept. 1984.

251. RIBEIRO FILHO, L.F. Acidente do trabalho. In: FUNDAÇÃO JORGE DUPRAT FIGUEIREDO DE SEGURANÇA E MEDICINA DO TRABALHO. Curso de medicina do trabalho. São Paulo: Fundacentro, 1979. v.3. p.765-768.

252. RIO, R.P.; PIRES, L. Ergonomia: fundamentos da prática ergonômica. Belo Horizonte: Health, 1999. 200p.

253.ROCHA, A.A.; GUIMARÃES, E.; ARAÚJO, F.R.K.; VASCONCELOS, G.M.F. A profissiografia e sua contribuição À avaliação da capacidade laborativa e na prevenção dos infortúnios laborais uma nova filosofia de empresa. In: CONGRESSO NACIONAL DE PREVENÇÃO DE ACIDENTES DO TRABALHO, 1978, São Paulo. Anais... São Paulo: Fundacentro, 1979. p.413-415.

254. RODRIGUES, M.V.C. Qualidade de vida no trabalho: evolução e análise no nível gerencial. Fortaleza: UNIFOR, 1991. 216p.

255. SALZMANN, J.A. Oral and dental diseases of occupational origin. In: MILLER, S.C. Oral diagnosis and treatment (oral medicine): a textbook for students and practitioners of dentistry and medicine. 3.ed. New York: McGrow Hill, 1957. Cap. 27. p.774-814.

256. SANTINO, E. Doença ocupacional por chumbo e seus compostos. In: VIEIRA, S.I. Medicina básica do trabalho. 2.ed. Curitiba: Gênesis. 1996, v.3. p.309-340.

257. SAPPINGTON, C.O. Etiology of dental sequelae. Ind Med, v.15, n.5, p.339-341, May 1946.

258. SAPPINGTON, C.O. The functions of industrial hygiene and their relationship to industrial dentistry. Ind Med, v.18, n.8, p.347-349, Aug. 1949. 
259. SBRISSA NETTO, J.M.; BIRMAN, E.G.; XAVIER, O.G.; ZAIA, P.A. Linha de Burton: estudo clínico e histopatológico. In: CONGRESSO NACIONAL DE PREVENÇÃO DE ACIDENTES DO TRABALHO, 1975, São Paulo. Anais... Rio de Janeiro: Ministério do Trabalho, 1975. p.855-868.

260. SCHOU, L. Oral health promotion at worksites. Int Dent J, v.39, n.2, p.122-128, June 1989.

261. SCHOUR, L.; SARNAT, B.G. Oral Manifestations of Occupational Origin. J Am Med Assoc, v.120, n.15, p.1197-1207, 1942.

262. SCHÜLER SOBRINHO, O. Temas de ciências sociais. In: VIEIRA, S.I. Medicina básica do trabalho. 2.ed. Curitiba: Gênesis. 1998. v.4. Cap. 20. p. 588-604.

263. SCHWARTZ, E. A proportionate mortality ratio analysis of pulp and paper mill workers in New Hampshire. Br $\mathbf{J}$ Ind Med, v.45, p.234238, 1988.

264. SELIGMANN-SILVA, E. Desgaste mental no trabalho dominado. Rio de Janeiro: Cortez, 1994. 322p.

265. SERVIÇO SOCIAL DA INDUSTRIA Higiene e segurança industrial. São Paulo: SESI, 1965. p.385-404.

266. SERVIÇO SOCIAL DA INDUSTRIA Saúde Bucal dos trabalhadores da construção civil. Rev CIPA, v.17, n.202, p.52-73, 1996.

267. SHAFER, W.G.; HINE, M.K.; LEVY, B.M. A textbook of oral pathology. 4.ed. Philadelphia: W.B. Saunders, 1983. Cap. 10. p.527-593.

268. SHALHOUB, S.Y. Na overview of industrial accidents with particular reference to facial trauma. Aust Dent J, v.36, n.6, p.445-450, Dec. 1991.

269. SILVA, F.C.T. Mutações do trabalho. Rio de Janeiro: SENAC Nacional, 1999. 128p.

270. SILVA, M. Documentos profissionais. In: SAMICO, A.H.R.; MENEZES, J.D.V.; SILVA, M. Aspectos éticos e legais do exercício da odontologia. 2.ed. Rio de Janeiro: Conselho Federal de Odontologia, 1994a. Cap. 11. p.76-88.

271. SILVA, M. Das perícias odonto-legais In: SAMICO, A.H.R.; MENEZES, J.D.V.; SILVA, M. Aspectos Éticos e Legais do Exercício da Odontologia. 2.ed. Rio de Janeiro: Conselho Federal de Odontologia, 1994b. Cap. 12. p.89-97. 
272. SILVA, M. Compêndio de odontologia legal. Rio de Janeiro: Medsi, 1997. 490p.

273. SILVA. M.A.D.; DE MARCHI, R. Saúde e qualidade de vida no trabalho. São Paulo: Best Seller, 1997. 181p.

274. SILVA, R.B.; SOUTO, D.F. Modelo de serviço assistencial em odontologia ocupacional $-1^{\underline{a}}$ parte. Odontol Mod, v.10, n.9, p.3639, set. 1983a.

275. SILVA, R.B.; SOUTO, D.F. Modelo de serviço assistencial em odontologia ocupacional $-2^{a}$ parte. Odontol Mod, v.10, n.10, p.3945, out. $1983 b$.

276. SILVA, R.B.; SOUTO, D.F. Modelo de serviço assistencial em odontologia ocupacional - $3^{\mathrm{a}}$ parte. Odontol Mod, v.10, n.11/12, p.27-30, nov./dez. 1983c.

277. SILVEIRA, A.M.; LADEIRA, R.M. Avaliação da experiência do ambulatório de doenças profissionais do hospital das clínicas da UFMG no tratamento de trabalhadores com saturnismo. Rev Bras Saúde Ocup, v.19, n.74, p.7-19, jul./dez. 1991.

278. SINDICATO NACIONAL DAS EMPRESAS DE ODONTOLOGIA DE GRUPO. Disponível em: http://www.sinog.com.br Acesso em 16 ago. 2000.

279. SINGER, P. A formação da classe operária: o que é classe operária? : a classe operária no Brasil : a sua formação e reprodução. 2.ed. São Paulo: Atual, Campinas: UNICAMP, 1985. $80 \mathrm{p}$.

280. SKOGEDAL, O.; SILNESS, J.; TANGERUD, T.; LAEGREID, O.; GILHUUS-MOE, O. Pilot study on dental erosion in a Norwegian electrolytic zinc factory. Community Dent Oral Epidemiol, v.5, n.5, p.248-251, 1977.

281. SMITH, A. Inquérito sobre a natureza e as causas da riqueza das nações. 2.ed. Lisboa: Fund. Caloustre Gulbenkian, 1980. v.1. 823p.

282. SONIS, S.T.; FAZIO, R.C.; FANG, L. Medicina oral. Rio de Janeiro: Guanabara, 1985. Cap. 38. p.338-339.

283. SRIKANDI, T.W.; CAREY, S.E.; CLARKE, N.G. Utilization of dental services and its relation to the periodontal status in a group of South Australian employees. Community Dent Oral Epidemiol, v.11, n.2, p.90-94, 1983.

284. TAMAKI, T. Dentaduras completas. 4.ed. São Paulo: Sarvier, 1983. $252 p$. 
285. TAN, H.H. Effect of dental health care instruction and prophylaxis on knowledge, attitude and behavior in Dutch military personnel. Community Dent Oral Epidemiol, v.7, n.5, p.252-258, dez. 1979.

286. TARZIA, O. Halitose. Rio de Janeiro: EPUC, 1991. 100p.

287. TEIGER, C. Les empreites du travail. équilibre ou fatigue par le travail? Paris: Enterprise Moderne, 1980. p.25-44.

288. TEIGER, C.; LAVILLE, A. Conditions de travail, santé, emploi (de quelques problèmes posés par l'approche ergonomique). Inserm, v. 104, p.309-326, 1981.

289. TENÓRIO, L.R.; JORDANO, A. Absenteísmo - doença em construção civil. In: 18을 CONGRESSO NACIONAL DE PREVENÇÃO DE ACIDENTES DO TRABALHO, 1979, Salvador. Anais... São Paulo: Fundacentro, 1980. p.21-26.

290. THIESS, A.M. An industrial medical department over 100 years old. The amazing story of the West German Badische Anilin-\&Soda-Fabric AG. Ind Med and Surg, v.38, n.9, p.281-289, Sept.1969.

291. THOMAS, E.H. Is the cause of so-called pyorrhea alveolaris constitutional? Dent Rev, v.31, p.192-207, May 1917.

292. THOMAS, E.H. Industrial dentistry and welfare work in Illinois. Dent Rev, v.32, p.199-211, Mar. 1918.

293. THOMAS, E.H. Mouth infection and industrial health. Ind Med v.13, n.11, p. 900-905, Nov. 1944.

294. THOMAS, E.H. Role of the oral surgeon in the determination of mouth infection, including the presence of pulpless teeth, in relation to systemic disease. J Am Dent Assoc, v.27, p.258-266, Feb. 1940.

295. THOMAS, E.H. Mouth infection in industrial workers: a serious menace to general health; resultant loss to war production. J Am Dent Assoc, v.30, p.1249-1262, Aug. 1943.

296. TOMMASI, A.F. Diagnóstico em patología bucal. São Paulo: Artes Médicas, 1988. 575p.

297. TUOMINEN, M.L. Occorrence of periodontal pockets and oral soft tissue lesions in relation to sulfuric acid fumes in the working environment. Acta Odontol Scand, v.49, p.261-266, 1991.

298. TUOMINEN, M.L.; TUOMINEN, R.J. Dental erosion and associated factors among factory workers exposed to inorganic acid fumes. Proc Finn Dent Soc, v.87, n.3, p.359-364, 1991a. 
299. TUOMINEN, M.L.; TUOMINEN, R.J. Tooth surface loss among people exposed to cement and stone dust in the work environment in Tanzania. Community Dent Health, v.8, p.233-238, 1991b.

300. TUOMINEN, M.L.; TUOMINEN, R.J.; FUBUSA, F.; MGALULA, N. Tooth surface loss and exposure to organic and inorganic acid fumes in workplace air. Community Dent Oral Epidemiol, v.19, p.217-220, 1991.

301. UNIODONTO DO BRASIL - Confederação Nacional das Cooperativas Odontológicas. O cooperativismo odontológico. Disponível em: http://www.uniodonto.com.br Acesso em 16 ago. 2000.

302. VASCONCELLOS, E.G. O modelo psiconeuroendocrinológico de Stress. In: SEGER, L. Psicologia e odontologia: uma abordagem integradora. 3.ed. São Paulo: Santos, 1998. Cap. 9. p.137-159.

303. VELASCO, L.E.L.; VELASCO, L.F.L.; MUNHOZ, M.F. A importância dos protetores bucais na prevenção de traumatismos dentários. Disponível em: http://odontologia.com.br/artigos/protetoresbucais.html Acesso em 16 mar. 1999.

304. VIEIRA, S.I. As patologias do trabalho sob pressão atmosférica anormal. In: VIEIRA, S.I. Medicina básica do trabalho. 2.ed. Curitiba: Gênesis. 1999. v.6. Cap. 9. p.141-152.

305. WALDMAN, H.B. Dentistry within the British National Health Service. J Am Dent Assoc, v.99, n.9, p.439-447, Sept. 1979.

306. WALDRON, H.A. Occupational health practice. 3.ed. Londres: Butterworths, 1989. p.440.

307. WALLS, R.M.; BETHLEHEM, P. A dental program for industry. J Am Dent Assoc, v.29, p.1083-1089, 1942.

308. WERTHER Jr., W.B.; DAVIS, K. Administração de pessoal e recursos humanos. São Paulo: McGraw-Hill do Brasil, 1983. 499p.

309. WESTERGAARD, J.; MOE, D.; PALLESEN, U.; HOLMEN, L. Exaggerated abrasion/erosion of human dental enamel surfaces: a case report. Scand J Dent Res, v.101, n.5, p.265-269, Oct. 1993.

310. WESTERMAN, B. A preventive dental care programme at workplace. Aust Dent J, v.38, n.3, p.210-215, June 1993.

311. WISNER, A. Por dentro do trabalho - Ergonomia: método \& técnica. Sâo Paulo: FTD/Oboré, 1987.198p.

312. WOTMAN, S. Dental Public Health: new opportunities - new responsibilities. J Public Health, v.51, n.2, p.103-107, Spring 1991. 
313.ZAVARIZ, C.; NOGUEIRA, D.P. Doença ocupacional causada pelo mercúrio e seus compostos. In: VIEIRA, S.I. Medicina básica do trabalho. 2.ed. Curitiba: Gênesis. 1998. v.4. Cap. 13. p. 213-258.

314.ZIMMERS, P.L.; GOBETTI, J.P. Head and neck lesions commonly found in musicians. J Am Dent Assoc, v.125, n.11, p.1487-1496, Nov. 1994. 


\title{
SUMMARY
}

\section{ODONTOLOGY IN WORKER'S HEALTH AS A NEW PROFESSIONAL SPECIALTY: DEFINITION OF THE ACTIVITY FIELD AND FUNCTIONS OF THE SURGEON DENTIST IN WORKER'S HEALTH TEAM}

\begin{abstract}
Brazilian companies are currently facing new challenges as a consequence of the economic globalization. Competitiveness, as well in the products area as in the services one, defies companies to increase their productivity and quality. In this scene, the human resources are more valued each day and entrepreneurs use programs to improve the worker's health and their working conditions. Ergonomics Programs, Total Quality, Working Quality of Life, Worker's Health team actions (SESMT) and many other benefits i.e. dental assistance, aim to improve the company competitiveness conditions. The surgeon-dentist does not take part in the health and safety team composition in the majority of the companies. According to the Literature Review from 1917 to 2000, odontology importance was not seen just for treatments, but also as an integrant part of the Worker's Health team. This study mainly outlined a more detailed vision of the evolution, performance and concept of Odontology in Worker's Health, allowing the surgeon-dentist new area of performance to be delimited. It has discussed the influence of some buccal diseases in the worker, its consequences, as well as the influence of the buccal health in absenteeism, productivity and risk of occupational accidents. The author suggests a definition for Odontology in Worker's Health, its objectives, politics and benefits for the worker, the company, Brazil, Working Health and Safety Team and Odontology. Analyzing 10 questionnaires applied in big companies of São Paulo state, Brazil, the author concluded that it is necessary a work of clarification and awareness of companies in general, workers, government, labor unions, Worker's Health and Odontology category professionals, to the importance and performance of the working surgeon-dentist. Some functions of the working surgeon-dentist specialized in Worker's Health Odontology would be prevention, diagnosis and treatment of buccal manifestations from occupational diseases, technical evaluations of odontologic treatments, expertise in the civil and working field assisting the health and safety team in the company work to improve its performance to reach its objectives. However, as the author outlines, for any new area, it is essential further research in this knowledge field; therefore, many questions still need to be elucidated and/or deepened and the performance in the Worker's Health Odontology area must be understood as the surgeon-dentist competence and an Odontology specialty at short term.
\end{abstract}


